PALEOCEANOGRAPHY, VOL. 4, NO. 4, PAGES 353-412, AUGUST 1989

\section{PLEISTOCENE EVOLUTION: NORTHERN HEMISPHERE \\ ICE SHEETS AND NORTH ATLANTIC OCEAN}

W. F. Ruddiman, ${ }^{1}$ M. E. Raymo, ${ }^{1,2}$ D. G. Martinson, ${ }^{1}$

B. M. Clement, ${ }^{3,4}$ and J. Backman ${ }^{5}$

Abstract. We analyze five high-resolution time series spanning the last $1.65 \mathrm{~m} . \mathrm{y} .:$ benthic foraminiferal $\delta^{18} \mathrm{O}$ and ${ }^{13} \mathrm{C}$, percent $\mathrm{CaCO}_{3}$, and estimated sea surface temperature (SST) at North Atlantic Deep Sea Drilling Project site 607 and percent $\mathrm{CaCO}_{3}$ at site 609 . Each record is a multicore composite verified for continuity by splicing among multiple holes. These climatic indices portray changes in northern hemisphere ice sheet size and in North Atlantic surface and deep circulation. By tuning obliquity and precession components in the $\delta^{18} \mathrm{O}$ record to orbital variations, we have devised a time scale (TP607) for the entire Pleistocene that agrees in age with all $\mathrm{K} / \mathrm{Ar}$-dated magnetic reversals to within $1.5 \%$. The Brunhes time scale is taken from Imbrie et al. [1984], except for differences near the stage $17 / 16$ transition $(0.70$ to $0.64 \mathrm{Ma})$. All indicators show a similar evolution from the Matuyama to the Brunhes chrons: orbital eccentricity and precession responses increased in amplitude; those at orbital obliquity decreased. The change in dominance from

${ }^{1}$ Lamont-Doherty Geological Observatory, Columbia University, Palisades, New York.

2 Now at Department of Geology, Monash University, Clayton, Victoria, Australia.

3 Ocean Drilling Program, Texas A and M University, College Station, Texas.

4 Now at Department of Geology, Florida International University, Miami, Florida.

5 Department of Geology, University of Stockholm, Stockholm, Sweden.

\section{Copyright 1989}

by the American Geophysical Union.

Paper number 89PA00434.

$0883-8305 / 89 / 89 \mathrm{PA}-00434 \$ 10.00$ obliquity to eccentricity occurred over several hundred thousand years, with fastest changes around 0.7 to $0.6 \mathrm{Ma}$. The coherent, in-phase responses of $8^{18} \mathrm{O}, 8^{13} \mathrm{C}, \mathrm{CaCO}_{3}$ and SST at these rhythms indicate that northern hemisphere ice volume changes have controlled most of the North Atlantic surfaceocean and deep-ocean responses for the last $1.6 \mathrm{~m} . \mathrm{y}$. The ${ }^{13} \mathrm{C}$, percent $\mathrm{CaCO}_{3}$, and SST records at site 607 also show prominent changes at low frequencies, including a prominent long-wavelength oscillation toward glacial conditions that is centered between 0.9 and $0.6 \mathrm{Ma}$. These changes appear to be associated neither with orbital forcing nor with changes in ice volume.

\section{INTRODUCTION}

During the later portion of the Brunhes Chron, high-latitude northern hemisphere climate was dominated by a quasi-periodic cycle of 100,000 years, close to periods of change in orbital eccentricity. This rhythm is registered in stable isotopic $\left(\delta^{18} \mathrm{O}\right)$ records that serve as proxies for global ice volume [Shackleton and Opdyke, 1973; Hays et al., 1976; Imbrie et al., 1984], in European and Chinese loess deposits [Kukla, 1970,1987 , and in other signals indicative of responses of the upper layers of the high-latitude North Atlantic Ocean [Ruddiman and McIntyre, 1981, 1984].

The strength of the 100,000-year rhythm has not, however, been constant through the Brunhes Chron. Imbrie [1985] found that it was weaker in amplitude by about half in $\delta^{18} \mathrm{O}$ signals from the early part of the Brunhes Chron (prior to 0.4 $\mathrm{Ma}$ ), and Ruddiman et al. [1986a] noted an analogous change in the surface temperature response of the North Atlantic Ocean. These differences suggest significant evolution of the climatic system within the Brunhes Chron.

Northern hemisphere climatic variations during the Matuyama Chron were very different. Records from hydraulic piston cores taken on Deep Sea Drilling Project (DSDP) leg 94 [Ruddiman et al., 1986b] support earlier suggestions [Shackleton and Opdyke, 1976; Pisias and Moore, 1981; Start and Prell, 1984] that the 41,000 -year period of orbital 


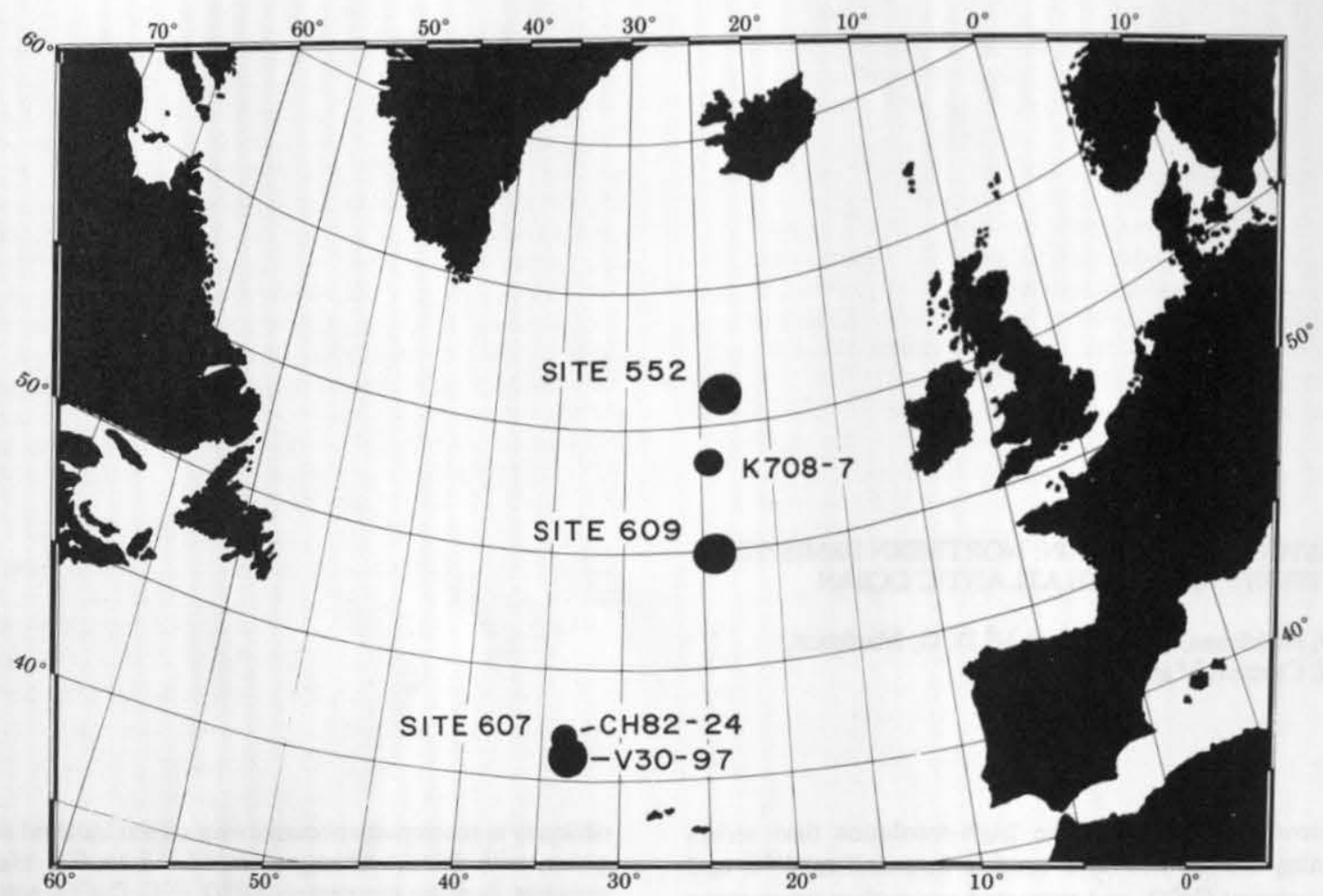

Fig. 1. Locations of DSDP sites and of nearby conventional piston cores. Core V30-97 almost directly overlays site 607 .

obliquity was the primary rhythm of northern hemisphere climatic change during the Matuyama Chron, with variations at periods near 100,000 years generally much weaker and even absent altogether during some intervals in the leg 94 records. This conclusion was based both on $\delta^{18} \mathrm{O}$ and other indicators known to be sensitive to northern hemisphere ice sheet size, such as estimated North Atlantic sea surface temperature (SST) and percent $\mathrm{CaCO}_{3}$. This 41,000 -year rhythm prevailed from the beginning of moderate-scale northem hemisphere glaciation near 2.6 to $2.4 \mathrm{Ma}$ [Backman, 1979; Shackleton et al., 1984] through most of the Matuyama Chron [Ruddiman et al., 1986b]. By $0.9 \mathrm{Ma}$, a longer-period, higher-amplitude signal had begun to develop [Shackleton and Opdyke, 1976; Pisias and Moore, 1981; Prell, 1982], leading to the Brunhes 100,000-year fluctuations.

We focus on the transition between regimes. When did it occur? Was it abrupt or gradual? Did other periodicities briefly emerge?

\section{CORE SELECTION}

The data for this study consist of composite depth and time series from DSDP sites in the northern subtropical and subpolar North Atlantic Ocean (Figure 1; Table 1). We report detailed records of $\delta^{18} \mathrm{O}, \delta^{13} \mathrm{C}$, percent $\mathrm{CaCO}_{3}$, and SST from the southernmost site (607), situated high on the upper western flank of the Mid-Atlantic Ridge. This site is located beneath the northern limb of the North Atlantic Drift flow in the subtropical gyre. It is also situated near piston cores V3097 and CHN82-24-4, both of which contain detailed records of late Pleistocene climatic change. Site 609 is located on the eastern flank of the Mid-Atlantic Ridge, beneath the diffuse northeastward flow of the North Atlantic Drift in the eastern Atlantic.

Also reported in this study are correlations with records from site 552 (hole 552A), located on the lower flank of the southwestern slope of the Rockall Plateau. Site 552 is

TABLE 1. Locations and Depths of DSDP Sites and Piston Cores

\begin{tabular}{lccc}
\hline & Latitude, $\mathrm{N}$ & Longitude, $\mathrm{W}$ & Depth, $\mathrm{m}$ \\
\hline Site 607 & $41^{\circ} 00^{\prime}$ & $32^{\circ} 58^{\prime}$ & 3427 \\
Core V30-97 & $41^{\circ} 00^{\prime}$ & $32^{\circ} 56^{\prime}$ & 3371 \\
Core CHN82-24-4 & $41^{\circ} 43^{\prime}$ & $32^{\circ} 51^{\prime}$ & 3427 \\
Site 609 & $49^{\circ} 53^{\prime}$ & $24^{\circ} 14^{\prime}$ & 3883 \\
Site 552 & $56^{\circ} 03^{\prime}$ & $23^{\circ} 14^{\prime}$ & 2311 \\
Core K708-7 & $53^{\circ} 56^{\prime}$ & $24^{\circ} 05^{\prime}$ & 3502 \\
\end{tabular}


situated beneath the broad northeastward flow of the North Atlantic Drift, somewhat north of the location of piston core K708-7.

\section{DATA ANALYSIS}

For site 607 , we present here $1.65-\mathrm{m} . y$. records of percent $\mathrm{CaCO}_{3}$ benthic foraminiferal $\delta^{18} \mathrm{O}$ and $\delta^{13} \mathrm{C}$, census counts of four species of planktonic foraminifera (Neogloboquadrina pachyderma sinistral, Globigerina bulloides, Globorotalia inflata, and Globigerinoides ruber), and estimated sea surface temperature (SST). For site 609, we report a 1.65 -m.y. record of percent $\mathrm{CaCO}_{3}$ for comparison with that of site 607 . Data for site 607 are listed in Tables A1 and A2 in the appendix, and $609 \mathrm{CaCO}_{3}$ values in Table A3. Data from a 1.2-m.y. record of the middle and late Pleistocene compiled from site 552 and piston core K708-7 have been reported by Ruddiman et al. [1986a].

High-resolution late Pleistocene records of $8^{18} \mathrm{O}$ and $8^{13} \mathrm{C}$ from cores V30-97 and CHN82-24-4 were used in place of the late Pleistocene section at site 607 , which was not analyzed. Data for $8^{18} \mathrm{O}$ and $8^{13} \mathrm{C}$ from core V30-97 were listed by Mix and Fairbanks [1985], and data for core CHN82-24-4 by Boyle and Keigwin [1985]. Relative to site 607, core V30-97 is closer in location, but core CHN82-24-4 is closer in depth (Table 1). Relative to the long isotopic record at site 607 presented here, the record in V30-97 relies more heavily on the genus Uvigerina, whereas that in core CHN82-24-4 relies entirely on Cibicidoides. We created stacked isotopic records of $\delta^{18} \mathrm{O}$ and $8^{13} \mathrm{C}$ from both of these late Pleistocene piston cores for splicing to the site 607 record.

We correlated the two piston cores by mapping the $\delta^{18} \mathrm{O}$ record of core CHN82-24-4 into that of core V30-97 in the time domain, using a time scale established by correlation of V $30-97$ to the $8^{18} \mathrm{O}$ stack of Imbrie et al. [1984]. Next, we resampled the $\delta^{18} \mathrm{O}$ record from each core at an interval of 3400 years and then stacked the two $8^{18} \mathrm{O}$ signals. We chose the 3400-year interval to achieve a sampling density equal to that in the deeper record from site 607 . The resampled values comprising the stacked $\delta^{18} \mathrm{O}$ signal are listed in Table A4, adjusted to Uvigerina. The two $\delta^{18} \mathrm{O}$ signals comprising this stack are very similar, except in isotopic stages 2,4 , and 6 , where the V30-97 record is heavier than CHN82-24-4. The resampled values comprising the stacked $\delta^{13} \mathrm{C}$ signal are also listed in Table A4, adjusted to Cibicidoides. We see no evidence in either paired or closely adjacent $\delta^{13} \mathrm{C}$ analyses of the kind of species-specific offsets measured in other regions [Zahn et al., 1986]. Apparently, North Atlantic productivity did not reach high enough levels to trigger additional carbon isotopic disequilibrium in Uvigerina.

Because the bottom of core CHN82-24-4 ends in the upper part of isotopic stage 7 , there is an interval between about 215,000 and 245,000 years B.P. through which the stacked record is based only on core V30-97. Over this interval, the V30-97 record was based on analyses of both Uvigerina and (adjusted) Cibicidoides [Mix and Fairbanks, 1985].

Table A5 contains census counts of planktonic foraminifera and SST estimates covering the last 250,000 years from core V30-97, and Table $\mathrm{A6}$ contains $\mathrm{CaCO}_{3}$ values. These were analyzed and reported by Ruddiman and McIntyre [1981, 1984], but were not previously published in tabular form. For the remainder of this paper, we refer to any records constructed by combining site 607 data with data from the two piston cores as the "site 607 " record.
The average sample spacing for all analyses is $15 \mathrm{~cm}$ at site 607 , equivalent to 3400 years. The spacing is $30 \mathrm{~cm}$ at site 609 (equivalent to 4100 years or less), except for $\mathrm{CaCO}_{3}$ analyses at $15-\mathrm{cm}$ intervals near core breaks. The original spacing for most analyses in cores V30-97 and CHN82-24-4 (before resampling) was $5 \mathrm{~cm}$, equal to average intervals of 1000 and 1600 years, respectively. For $\mathrm{CaCO}_{3}$, the original sample spacing in V30-97 was $2 \mathrm{~cm}$, equivalent to 400 years.

All $\mathrm{CaCO}_{3}$ values were determined by gasometric analyses of bulk sediment following techniques described by Hulsemann [1966]. The reproducibility of replicate analyses was 1-2\%. The faunal counts and estimates of sea surface temperature follow the simplified North Atlantic counting requirements (four species and an "other" category) and the transfer function equation of Ruddiman and Esmay [1986], with standard errors of estimate for SST values of about $2^{\circ} \mathrm{C}$.

All $8^{18} \mathrm{O}$ and $\delta^{13} \mathrm{C}$ analyses at site 607 (Table A1) were made using a Carousel- 48 automatic carbonate preparation device attached to a Finnegan-MAT 251 mass spectrometer. Analytical precision for this machine on replicate standards was $0.10 \%$ for $\delta^{18} \mathrm{O}$ and $0.05 \%$ for $\delta^{13} \mathrm{C}$. Precision on replicate samples for this study was $0.2 \%$ for $\delta^{18} \mathrm{O}$ and $0.1 \%$ for $\delta^{13} \mathrm{C}$. Calibration to the PDB standard is via the NBS-16, NBS-17, NBS-19, and NBS-20 standards. Values of $\delta^{18} \mathrm{O}$ and $\delta^{13} \mathrm{C}$ for Cibicidoides wuellerstorfi and Cibicidoides kullenbergi are reported unadjusted in Table A1. In order to create a composite $\delta^{18} \mathrm{O}$ record, we followed standard practice by adding $0.64 \%$ to analyses of Cibicidoides to make them comparable to Uvigerina, which appears to have deposited calcite in oxygen isotopic equilibrium with seawater. We also follow standard practice by adding $0.9 \%$ to $\delta^{13} \mathrm{C}$ values measured on Uvigerina to bring them into equilibrium with Cibicidoides, which is in near equilibrium with seawater.

Ruddiman et al. [1986c] previously reported numerous site $6078^{18} \mathrm{O}$ analyses run on a VG 903 mass spectrometer. In general, the VG 903 values for a given sample were considerably lighter than the MAT 251 values, with differences often in excess of $0.5 \%$ and sometimes in excess of $1.0 \%$. We were unable to determine the reason for this extremely poor reproducibility; all samples for both machines were prepared using standard (and identical) techniques, and all samples were run during an interval when standards on both machines appeared acceptable. Because the VG 903 data from site 607 were much noisier than the MAT 251 data, both in terms of analysis of duplicates and reproducibility of basic downcore trends, we discarded all VG data, repicked the discarded samples, and reran them on the MAT 251. The resulting $8^{18} \mathrm{O}$ and $\delta^{13} \mathrm{C}$ trends from site 607 have an acceptably low noise level.

\section{COMPOSITE DEPTH SECTIONS}

Analysis of time series from sequences of hydraulic piston cores are complicated by gaps in the record at breaks between successive cores caused by disturbances associated with the coring process. These gaps may range from a few centimeters to several meters in length. With coring of two or more holes at a site, it is possible to splice across these gaps by correlating into the offset hole and then back into the main hole. For sites 607 and 609 , this was done onboard leg 94 based on visual examination of the $\mathrm{CaCO}_{3}$ layering of North Atlantic sediments [Ruddiman et al., 1986d]. All shipboard correlations have subsequently been checked by $\mathrm{CaCO}_{3}$ analyses and in some cases adjusted slightly. 

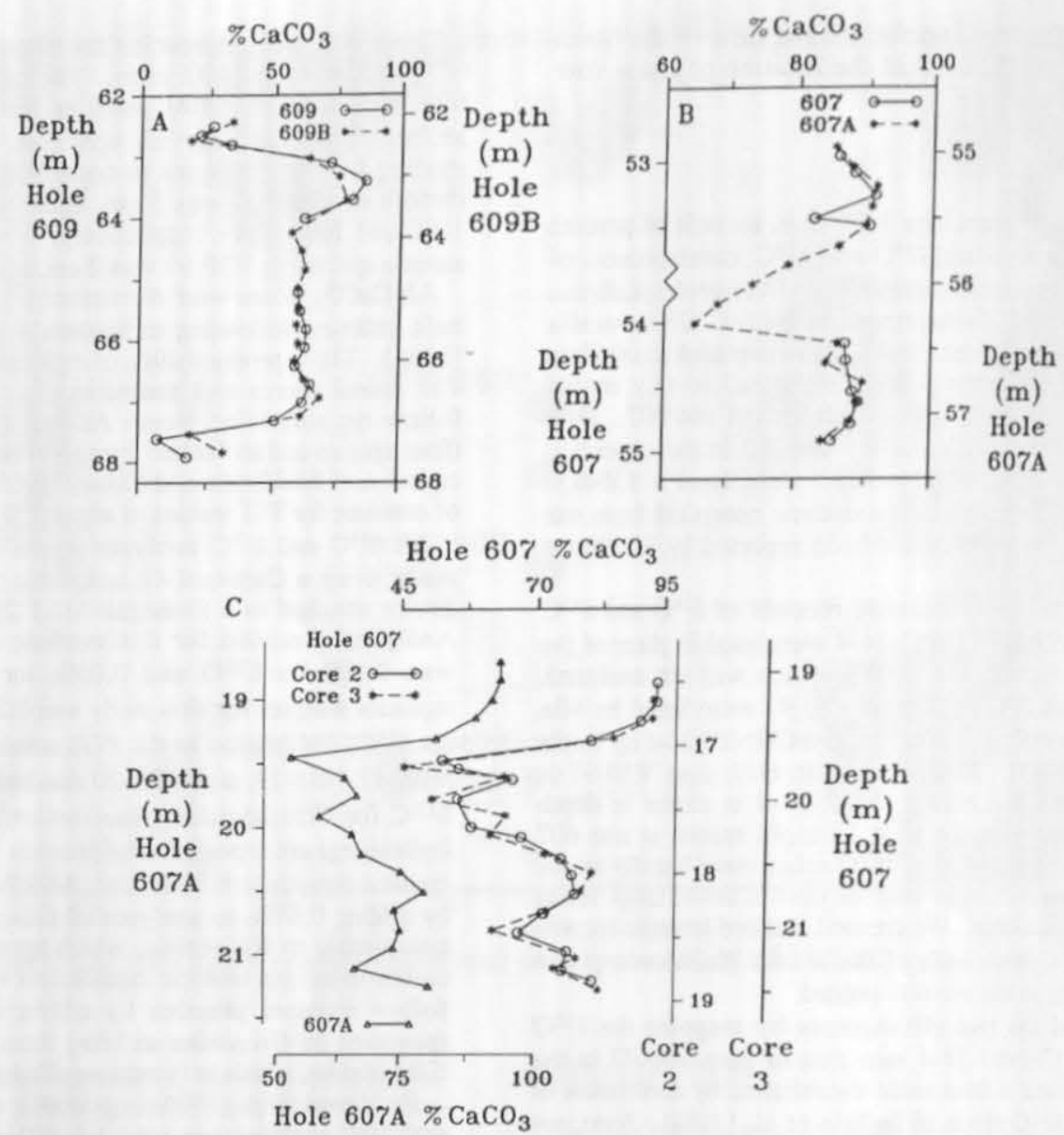

Fig. 2. Examples of between-hole splices and HPC-coring problems based on percent $\mathrm{CaCO}_{3}$ (a) core splice from site 609, with negligible loss of $\mathrm{CaCO}_{3}$ signal at hole 609 in the break between cores; (b) core splice from site 607, with full (41,000-year) $\mathrm{CaCO}_{3}$ cycle lost at hole 607 in the break between cores; and (c) double-coring at site 607 . The top of core 3 at hole 607 recored the same section already recovered in the bottom of core 2 . The record from hole $(607 \mathrm{~A})$ is also shown offset to left for comparison.

Examples are shown in Figure 2. In the example from site 609 (Figure 2a), little additional information is provided by splicing a short section of core $609 \mathrm{~A}-8$ into the gap between cores 609-7 and 609-8. In the example from site 607 (Figure $2 \mathrm{~b})$, however, splicing roughly $1 \mathrm{~m}$ of core $607 \mathrm{~A}-7$ into the gap between cores $607-6$ and $607-7$ adds a major (41,000-year) $\mathrm{CaCO}_{3}$ fluctuation to the composite record. Another kind of coring problem is shown in Figure 2c: an interval spanning stages 11 and 12 was cored in the bottom of core $607-2$ and then recored in the top of core 607-3, as proven by the overlay of $\mathrm{CaCO}_{3}$ signals. Heaving and drifting of the ship apparently moved the bottom-hole assembly away from the center of the hole due to incomplete seating in the watery upper sediments.

Using these techniques, we have correlated across every core break in the entire Pleistocene record at site 609 and across all but one core break at site 607 (Tables 2 and 3). At site 607 , we could not splice core 607A-4 into the break between cores $607-3$ and $607-4$, because core $607 \mathrm{~A}-4$ contained a slump. As a result, we joined the bottom of core 607-3 directly to the top of core $607-4$. Correlations to other $\delta^{18} \mathrm{O}$ records discussed later suggest that no significant thickness of sediment is missing across this core break.
The composite Pleistocene depth models at sites 607 and 609 (Tables 2 and 3; Figure 3) are based primarily on long sections in the main holes (607 and 609), joined by shorter sections in the offset holes (607A and 609B). Composite depth models are assembled at each site by assigning the sediment-water interface a depth of $0 \mathrm{~m}$ and incrementally adding the length of each subsequent spliced section down through the sediment column (Tables 2 and 3 ). The composite subbottom depths usually differ by less than $2 \mathrm{~m}$ from those obtained from standard DSDP depth-recording conventions. Composite subbottom depths of individual samples are listed in the appendix.

Because the $\mathrm{CaCO}_{3}$ samples used to verify these splices were on average run at $15-\mathrm{cm}$ intervals, most of the splices are accurate to within at least $15 \mathrm{~cm}$, representing about 3500 years at site 607 and 2000 years at site 609 . In most of the Pleistocene splices at these two sites, visual correlations of $\mathrm{CaCO}_{3}$ layering can resolve the correlations to within about 5 to $10 \mathrm{~cm}$, representing 2000 years or less.

Overlapped $\mathrm{CaCO}_{3}$ records were also used to join the late Pleistocene piston core data to the earlier sections from the DSDP sites. Piston core V30-97 ends at the $8^{18} \mathrm{O}$ stage $8 / 7$ 
TABLE 2. Composite Depth Model for Site 607

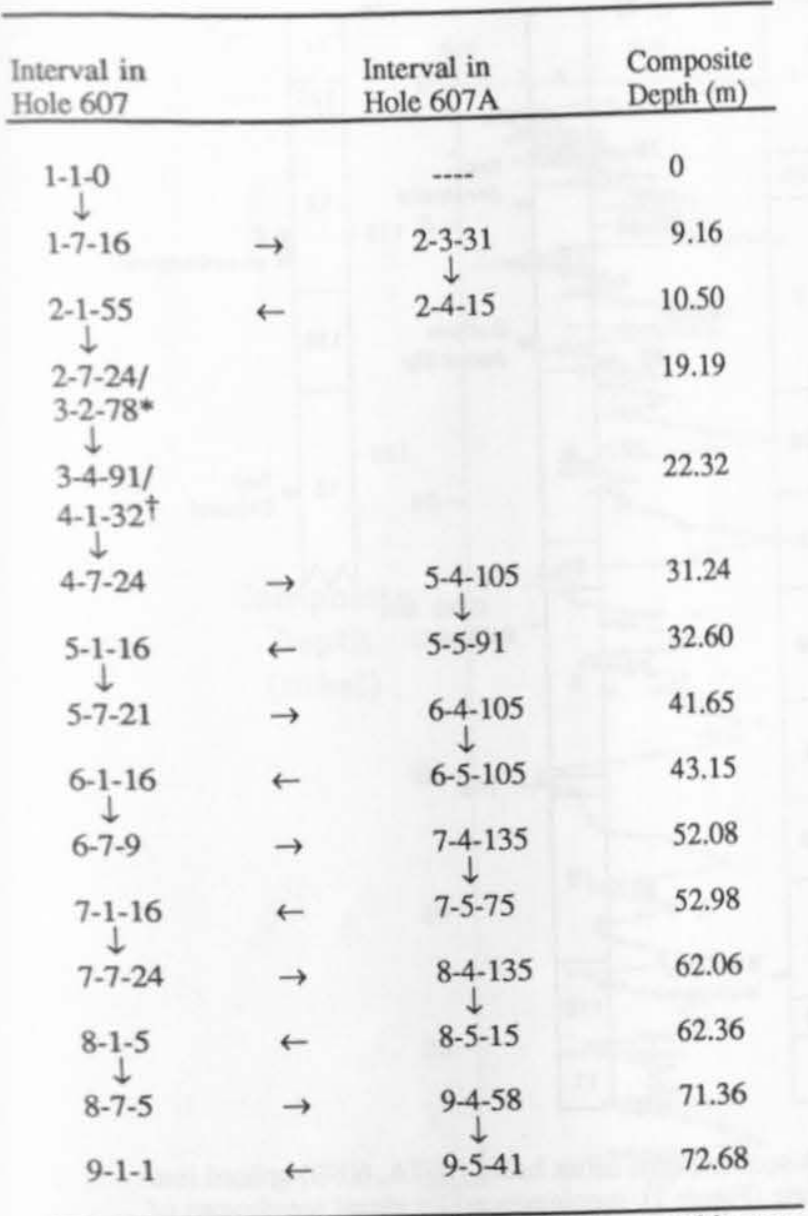

* Sequence cored in bottom of core 607-2 recored in top of 607-3.

†No splice attempted across this core break.

boundary at a depth of $9.16 \mathrm{~m}$; this precisely matches the age and depth of the bottom of core $607-1$ in the site 607 composite depth section (Table 2). Thus, core V30-97 was directly substituted for HPC core 607-1 in the composite depth section. Also, because we mapped the CHN82-24-4 $\delta^{18} \mathrm{O}$ record into the $\mathrm{V} 30-97 \delta^{18} \mathrm{O}$ record, the stacked $\delta^{18} \mathrm{O}$ record from both cores could be directly substituted in the composite depth model. The complete Pleistocene $\delta^{18} \mathrm{O}$ record at site 607 is shown plotted to composite depth in Figure 4. For the rest of this paper, all composite subbottom depths will be referred to simply as "depth" or "subbottom depth."

\section{STRATIGRAPHY}

DSDP leg 94 shipboard magnetic stratigraphy, supplemented by subsequent postcruise analyses, provides the primary stratigraphy. Initial shipboard determinations were made at average intervals of $1.5 \mathrm{~m}$ [Clement and Robinson, 1986]. Later analyses of some reversals at much closer intervals with continuous " $\mathrm{U}$ channel" sampling were reported by Clement and Kent [1986, 1987]. Additional work is included here.

The range of uncertainty in placement of magnetic reversals versus depth in each hole at sites 607 and 609 is listed in Table 4. With magnetic reversal measurements available from two holes at each site, it is possible to narrow the range of uncertainty in depth placement of most reversals by using

TABLE 3. Composite Depth Model for Site 609

\begin{tabular}{|c|c|c|c|}
\hline $\begin{array}{l}\text { Interval in } \\
\text { Hole } 609 \\
\end{array}$ & & $\begin{array}{l}\text { Interval in } \\
\text { Hole 609B } \\
\end{array}$ & $\begin{array}{l}\text { Composite } \\
\text { Depth (m) }\end{array}$ \\
\hline $\begin{array}{c}1-1-0 \\
\downarrow\end{array}$ & & & 0 \\
\hline $1-5-79$ & $\rightarrow$ & $\begin{array}{c}2-3-30 \\
\downarrow\end{array}$ & 6.79 \\
\hline$\underset{\downarrow}{2-1-31}$ & $\leftarrow$ & $2-4-91$ & 8.90 \\
\hline $2-7-1$ & $\rightarrow$ & $\begin{array}{c}3-3-1 \\
\downarrow\end{array}$ & 17.60 \\
\hline 3-3-90 & $\leftarrow$ & $3-6-15$ & 22.24 \\
\hline $3-6-75 *$ & $\rightarrow$ & $\begin{array}{c}4-2-1 * \\
\downarrow\end{array}$ & 26.59 \\
\hline$\underset{\downarrow}{4-3-1}$ & $\leftarrow$ & $4-5-61$ & 31.68 \\
\hline $4-6-1$ & $\rightarrow$ & $\begin{array}{c}5-2-91 \\
\downarrow\end{array}$ & 36.18 \\
\hline $\begin{array}{c}5-3-1 \\
\downarrow\end{array}$ & $\leftarrow$ & $5-5-1$ & 39.78 \\
\hline $5-6-91$ & $\rightarrow$ & $\begin{array}{c}6-2-31 \\
\downarrow\end{array}$ & 45.18 \\
\hline $\begin{array}{c}6-1-31 \\
\downarrow\end{array}$ & $\leftarrow$ & $6-3-61$ & 46.98 \\
\hline $6-7-51$ & $\rightarrow$ & $\begin{array}{c}7-2-121 \\
\downarrow\end{array}$ & 56.18 \\
\hline $\begin{array}{c}7-1-31 \\
\downarrow\end{array}$ & $\leftarrow$ & $7-3-31$ & 56.78 \\
\hline $7-7-1$ & $\rightarrow$ & $\begin{array}{c}8-2-121 \\
\downarrow\end{array}$ & 65.48 \\
\hline$\stackrel{8-1-61}{\downarrow}$ & $\leftarrow$ & $8-3-61$ & 66.38 \\
\hline $8-6-91 *$ & $\rightarrow$ & $\begin{array}{c}9-1-121 * \\
\downarrow\end{array}$ & 74.18 \\
\hline $\begin{array}{c}9-1-31 \\
\downarrow\end{array}$ & $\leftarrow$ & $9-3-45$ & 76.42 \\
\hline $9-6-121$ & $\rightarrow$ & $\begin{array}{c}10-2-61 \\
\downarrow\end{array}$ & 84.82 \\
\hline $\begin{array}{c}10-1-61 \\
\downarrow\end{array}$ & $\leftarrow$ & $10-3-1$ & 85.72 \\
\hline $10-6-61$ & $\rightarrow$ & $\begin{array}{c}11-2-0 \\
\downarrow\end{array}$ & 93.22 \\
\hline $\begin{array}{c}11-2-61 \\
\downarrow\end{array}$ & $\leftarrow$ & $11-4-121$ & 97.43 \\
\hline $11-6-24 *$ & $\rightarrow$ & $\begin{array}{c}12-2-1 * \\
\downarrow\end{array}$ & 103.06 \\
\hline $\begin{array}{c}12-1-11 \\
\downarrow\end{array}$ & $\leftarrow$ & $12-3-1$ & 104.56 \\
\hline $12-6-61 *$ & $\rightarrow$ & $\begin{array}{c}13-2-1 * \\
\downarrow\end{array}$ & 112.56 \\
\hline $13-2-61$ & $\leftarrow$ & $13-5-1$ & 117.06 \\
\hline
\end{tabular}

${ }^{*}$ Greater uncertainty in determining splice depths. 
Site 607

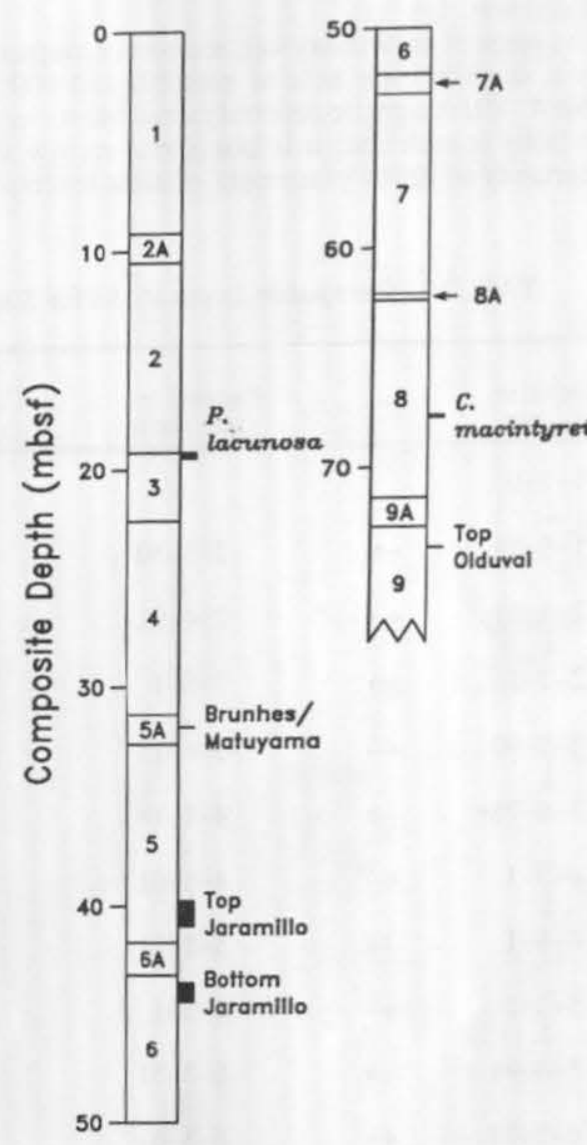

\section{Site 609}

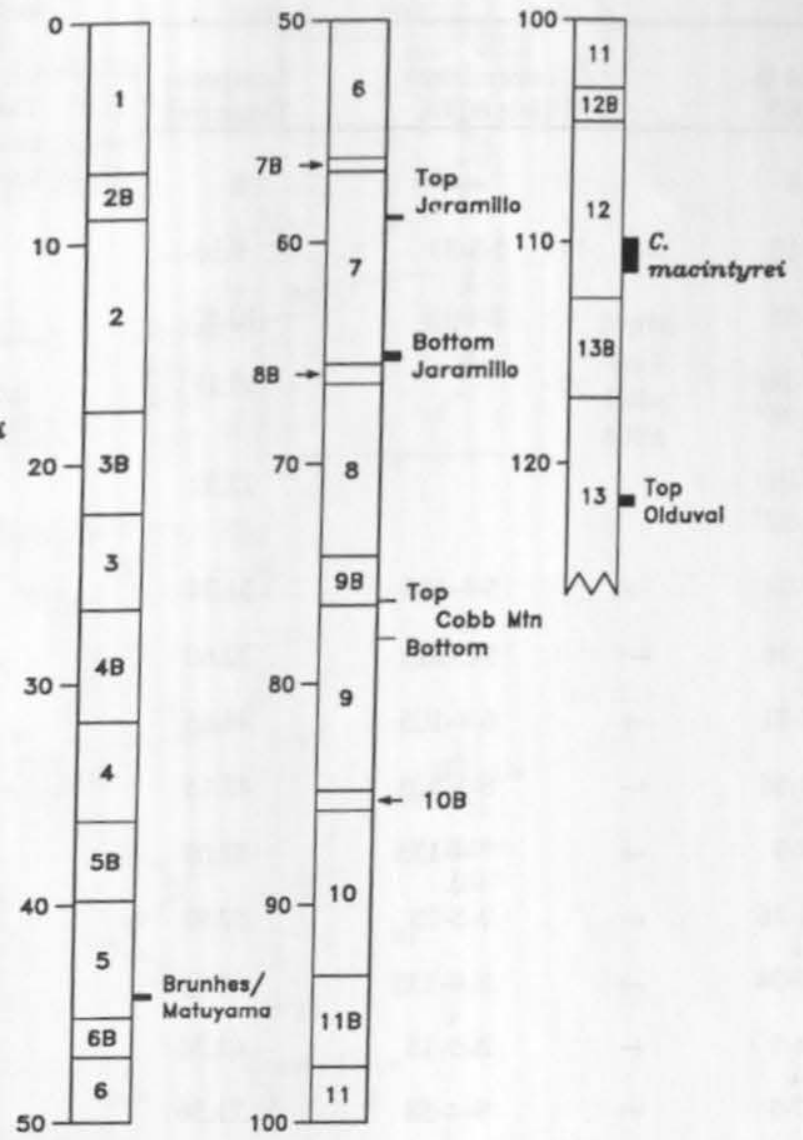

Fig. 3. Composite depth sections for sites 607 and 609 , with sections from offset holes $(607 \mathrm{~A}, 609 \mathrm{~B})$ spliced into main holes $(607,609)$. Splices are based on $\mathrm{CaCO}_{3}$ correlations (Figure 2), supplemented by visual correlations of layering from core photographs. The range of uncertainty of depths of magnetic reversals (and of last occurrences of C. macintyrei and $P$. lacunosa) is shown by solid bars to right of the composite depth columns.

between-hole correlations. This involves using the hole that spans the reversal and is included in the composite depth section (Tables 2 and 3; Figure 3 ) as a standard of reference into which the magnetic record from the other hole is projected by correlation. In all such cases, the between-hole correlations near the magnetic reversals were of very high quality, and the depths of the magnetic reversals could be transferred with an uncertainty of less than $10 \mathrm{~cm}$ (about 2000 years). The common depth overlap of the reversal as measured both in the main hole and in the offset hole (correlated into the main hole) then narrows the reversal depth range.

All composite depth ranges of magnetic reversals listed in Table 4 are shown in the composite site 607 and 609 depth sections in Figure 3. Also shown are the depth ranges of the Pseudoemiliania lacunosa and Coccolithus macintyrei datums.

\section{TESTS OF TIME SCALE METHODOLOGY}

The SPECMAP time scale for the Brunhes portion of the Pleistocene [Imbrie et al., 1984] was developed by identifying minima and maxima in a stacked composite of stable isotope $\left(8^{18} \mathrm{O}\right)$ records and linking these features to specific minima and maxima in orbital insolation forcing at the periods of obliquity (41,000 years) and precession (23,000 and 19,000 years). The $\delta^{18} \mathrm{O}$ events were assigned lags behind the forcing based on assumed ice sheet physics: roughly 8000 years for events related to obliquity forcing, and 4000 to 5000 years for events related to precessional forcing. The resulting time scale produced a good match in amplitude modulation between orbital forcing and the $\delta^{18} \mathrm{O}$ response for obliquity and an extraordinary match for precession [Imbrie et al., 1984].

Martinson et al. [1987] showed that a number of orbital tuning approaches yield effectively identical results in the late Pleistocene. This validates in a general way both the correlation to orbital insolation curves used by Imbrie et al. [1984], as well as the methods used later in this paper.

Here we apply the same methodology to the $\delta^{18} \mathrm{O}$ record from site 607 to develop a time scale for the Matuyama portion of the Pleistocene, after initially testing several key assumptions. First, we verify that Ruddiman et al. [1986b] defined the correct match between $\delta^{18} \mathrm{O}$ cycles and obliquity forcing in the Matuyama portion of the record, including the long interval unconstrained by magnetic reversal datums between about 1.1 and $1.66 \mathrm{Ma}$. Then we show that the 


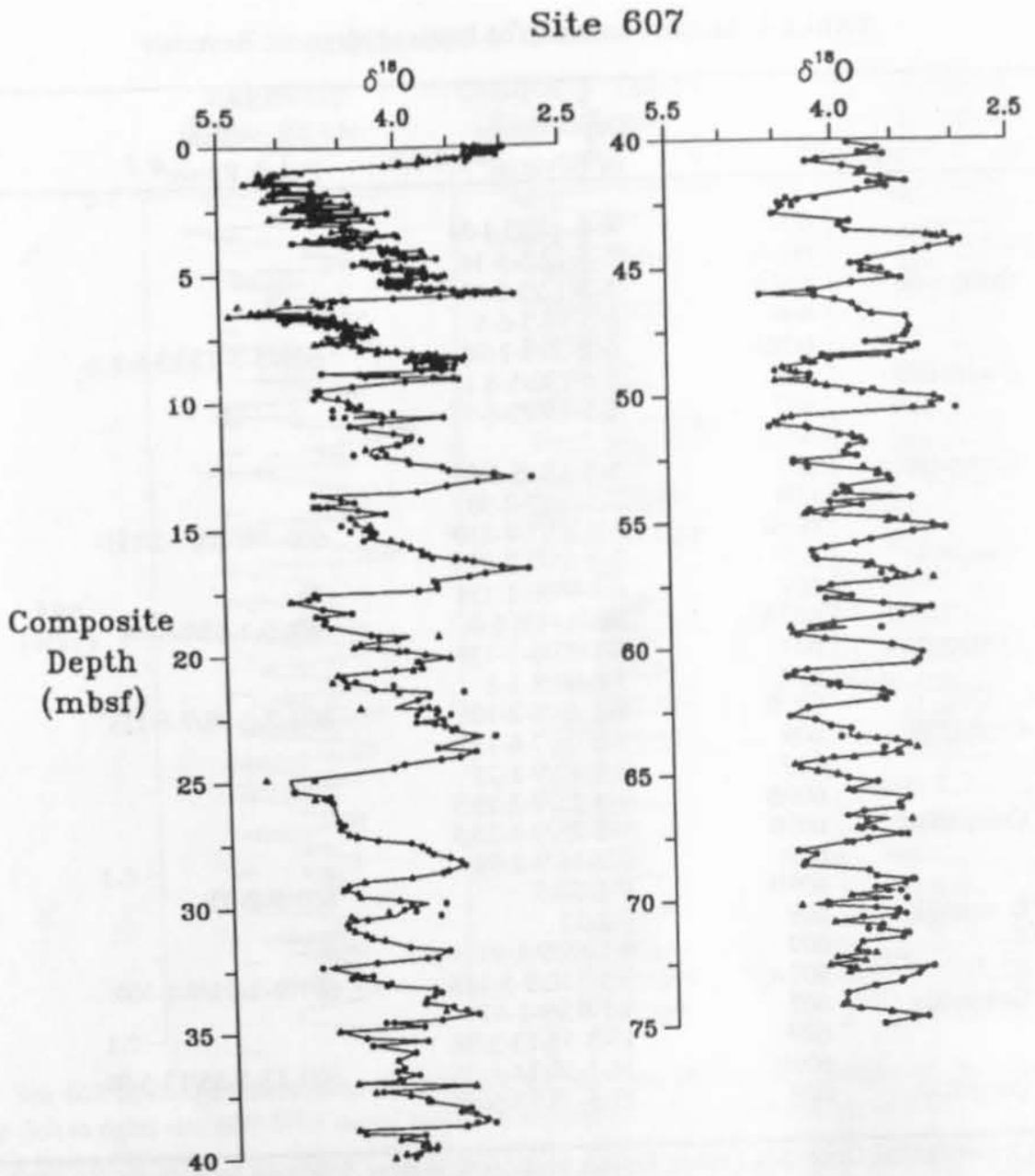

Fig. 4. Site $607 \delta^{18} \mathrm{O}$ record plotted to composite depth (record above 250,000 years based on cores V $30-97$ and CHN82-24-4). Individual analyses of Cibicidoides (circles) and $U$ vigerina (triangles) are shown.

precessional component of the Brunhes $\delta^{18} \mathrm{O}$ record at site 607 is correlated to orbital forcing and provides a useful additional criterion for tuning at least the upper part of the Matuyama record.

\section{Testing the Match of Obliquity Cycles}

Using K/Ar-dated magnetic reversals for initial chronologic control, Ruddiman et al. [1986b] found that oscillations in $\delta^{18} \mathrm{O}$, percent $\mathrm{CaCO}_{3}$ and estimated SST at site 607 during the late Matuyama were concentrated at a period near that of orbital obliquity. These oscillations were used to tune the record by assigning each a 10,000-year lag behind a specific obliquity minimum or maximum.

These initial efforts depended solely on counting the number of tilt cycles in the interval between the upper Olduvai subchron boundary and the Brunhes-Matuyama reversal. Although constrained at several levels by other dated magnetic reversals, such an approach depends critically on neither skipping tilt cycles in the $\delta^{18} \mathrm{O}$ record nor adding extra ones.

We can use the site $607 \delta^{18} \mathrm{O}$ record to test whether or not the amplitude variations of orbital obliquity and of the $8^{18} \mathrm{O}$ response at the same period are sufficiently coherent to support or refute the Obliquity time scale match. We focus on the interval between 1.48 and $1.07 \mathrm{Ma}$, which contains a very pure obliquity signal evident in both untuned $\delta^{18} \mathrm{O}$ records and in the Obliquity time scale (Figure 5). (Note that despite the addition of new $\delta^{18} \mathrm{O}$ data, the original Obliquity time scale still captures the major 41,000 -year $\delta^{18} \mathrm{O}$ oscillations at site 607 clearly.)

We made three different correlations between the 10 orbital obliquity cycles within this 41,000 -year interval and the 10 $\delta^{18} \mathrm{O}$ events in the site 607 record over the same interval. One correlation followed the match used for the Obliquity time scale (as in Figure 5), and the other two matches were made by moving the $\delta^{18} \mathrm{O}$ record up and down one obliquity cycle. In accord with Imbrie et al. [1984], we lagged the $\delta^{18} \mathrm{O}$ signal 8000 years behind the 41,000 -year obliquity forcing for each of the three proposed matches.

The match of $\delta^{18} \mathrm{O}$ events with orbital obliquity used in the Obliquity time scale gave a slightly higher correlation than the 
TABLE 4. Sample Constraints on Levels of Magnetic Reversals

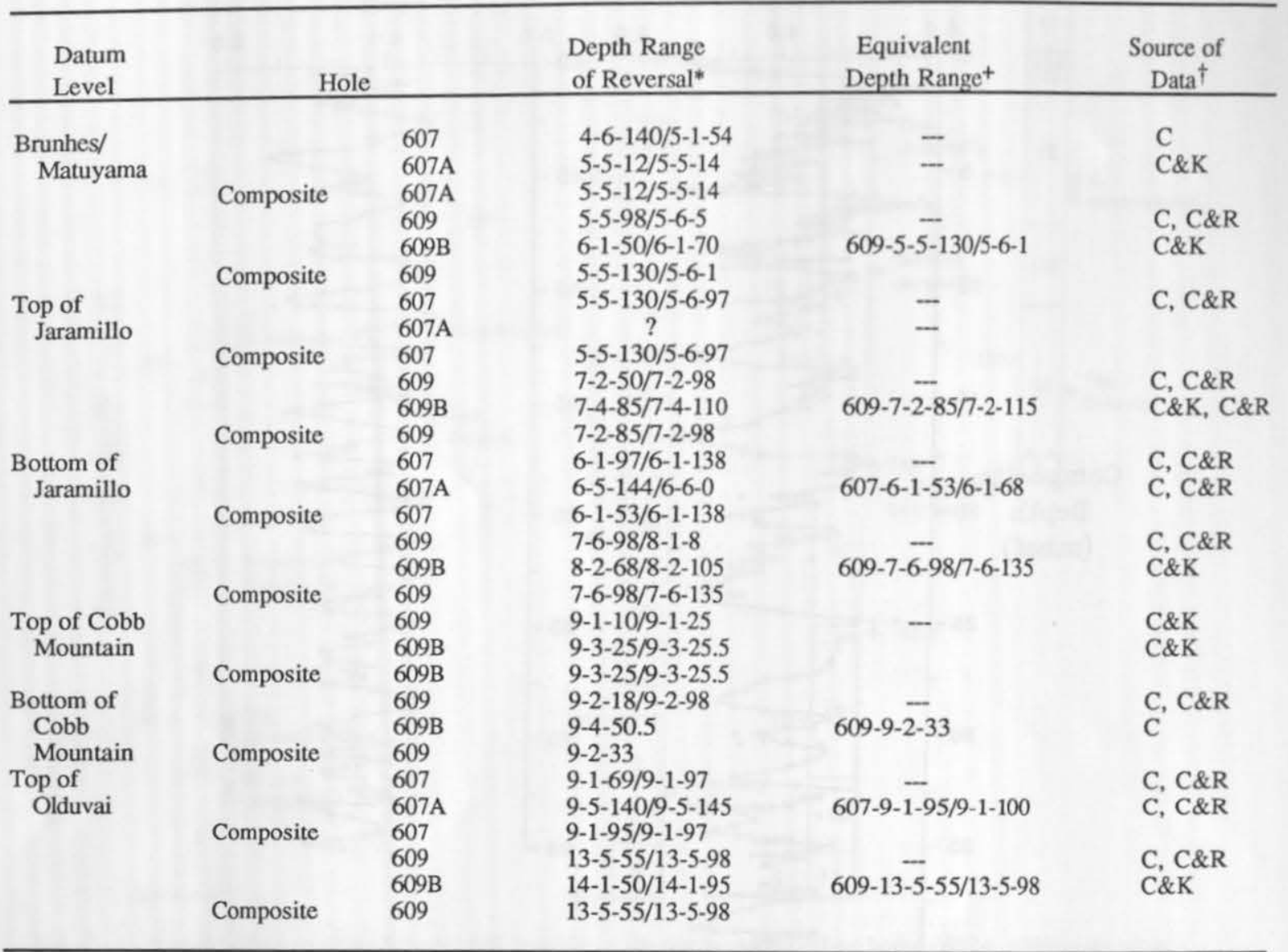

*Depths shown in conventional Deep-Sea Drilling Project units: hole number, followed by core-section-depth in section (in $\mathrm{cm}$ ).

+Depths of several magnetic reversals measured directly in offset hole and then transferred by $\mathrm{CaCO}_{3}$ or visual correlations into the hole used as part of the composite depth sequence.

†C\&R is Clement and Robinson [1986]; C\&K, Clement and Kent [1986, 1987]; C, Clement (new work reported in this paper).

other two matches, but the difference was insignificant (Table 5). These results show that simple linear correlation at the obliquity rhythm alone at site 607 is not a highly diagnostic criterion for verifying a time scale.

Next, we tried using sedimentation rate changes as a criterion to test matches between orbital obliquity and site 607 $\delta^{18} \mathrm{O}$ cycles. We first chose the same $10 \delta^{18} \mathrm{O} /$ obliquity cycles from the previous test and calculated the correlation between the centimeter length of each half cycle and the Kiloyear duration of the corresponding orbital obliquity half cycle. We again used the match from the Obliquity time scale and other correlations with the orbital obliquity signal shifted up and down one cycle. The match from the Obliquity time scale produced the highest positive correlation coefficient (Table 5). We then extended the comparison to include all $\delta^{18} \mathrm{O}$ stages from 1.07 Ma back to the top of the Olduvai subchron, and the Obliquity time scale again gave the best correlation (Table 5).

The Obliquity time scale thus appears to define the best $\delta^{18} \mathrm{O} /$ orbital match at the obliquity period for the long gap between magnetic reversal constraints at the top of the Olduvai subchron (about $1.66 \mathrm{Ma}$ ) and the Cobb Mountain event (K/Ar-dated at $1.1 \mathrm{Ma}$ ). The Obliquity time scale match in the Matuyama Chron younger than $1.1 \mathrm{Ma}$ is anchored by K/Ardated constraints at the Brunhes/Matuyama boundary $(0.73 \mathrm{Ma})$ and at the top and bottom of the Jaramillo subchron ( 0.90 and $0.97 \mathrm{Ma})$.

\section{Testing Precessional Modulation of $8^{18} \mathrm{O}$ at Site 607}

Next we used the Brunhes $\delta^{18} \mathrm{O}$ record from site 607 to test whether or not there is a reliable precessional cycle and whether or not it is modulated similarly to the SPECMAP $\delta^{18} \mathrm{O}$ stack [Prell et al., 1986] and to the orbital forcing. If so, the precessional signal in the site 607 record should be a valid basis for additional tuning of the Obliquity time scale in the early Pleistocene.

We accept the shape of the SPECMAP $\delta^{18} \mathrm{O}$ stack for the Brunhes as definitive, with one exception: the amplitude of isotopic event 18.4 at $0.721 \mathrm{Ma}$ in the SPECMAP $\delta^{18} \mathrm{O}$ stack 


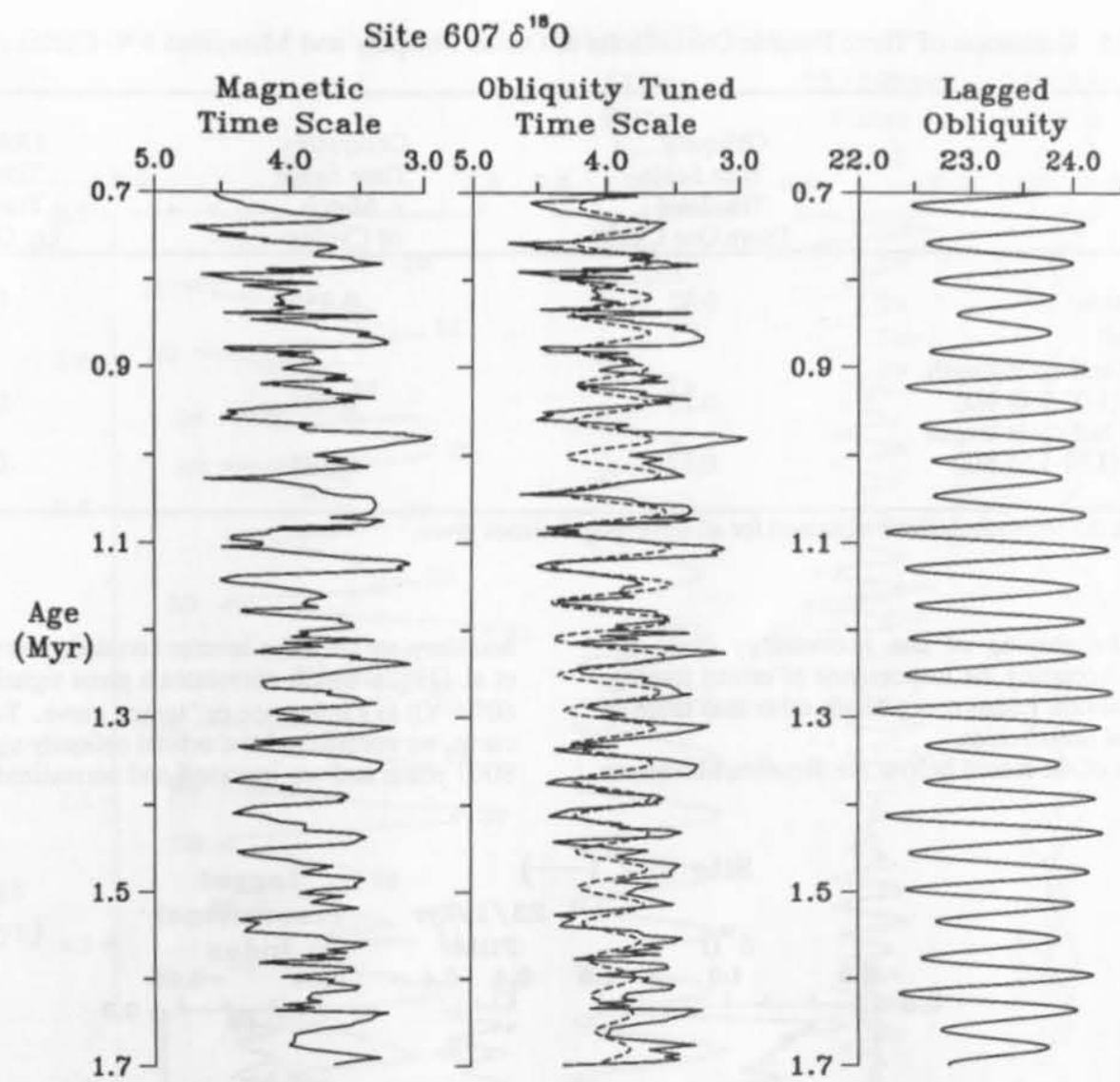

Fig. 5. Site 607 benthic foraminiferal $\delta^{18} \mathrm{O}$ record through the Pleistocene portion of the Matuyama Chron, showing (left to right) site $607 \delta^{18} \mathrm{O}$ record plotted to magnetic reversal chronology, site $607 \delta^{18} \mathrm{O}$ record tuned to orbital tilt (using Obliquity time scale of Ruddiman et al., [1986b] with filtered obliquity signal (dashed line), and orbital obliquity lagged 10,000 years. Obliquity filters here (and hereafter) have a central frequency of 0.0247 cycles/kyr and bandwidth $0.0223-0.0271 \mathrm{cycles} / \mathrm{kyr}$.

is substantially underrepresented compared to the $\delta^{18} \mathrm{O}$ record from site 607 (Figure 6). Several high-resolution $\delta^{18} \mathrm{O}$ records derived from both planktonic and benthic foraminifera resemble the site 607 version of event 18.4 more closely than they do the SPECMAP stack: see piston core V28-239 [Shackleton and Opdyke, 1976] and DSDP sites 502 [Prell, 1982], 504 [Shackleton and Hall, 1983], and 552A [Shackleton et al., 1984].

The correlation between the site $607 \delta^{18} \mathrm{O}$ record and the SPECMAP $\delta^{18} \mathrm{O}$ stack (Figure 6) is 0.88 . There are some dissimilarities within isotopic stage 14 near 0.55 to $0.475 \mathrm{Ma}$, a region of relatively low sedimentation rates at site $607(1-2$ $\mathrm{cm} / 1000$ years). Because these disagreements occur within core $607-3$, they are not related to the unspliced core break between cores 607-3 and 607-4. That core break occurs within stage 15 , which has the same structure in the site 607 record as in the SPECMAP stack (Figure 6).

The correlation between the filtered orbital components of these two $\delta^{18} \mathrm{O}$ signals is very high, with a coherence-squared value of 0.95 for precession, 0.97 for tilt, and 0.95 for eccentricity. The coherence between the precessional component of $\delta^{18} \mathrm{O}$ and the orbital precessional index is moderately high $(0.87)$. In general, the amplitude modulation of the site $607 \delta^{18} \mathrm{O}$ record in the precessional band is similar both to the SPECMAP curve and to the orbital precessional index (Figure 6), except for offsets of the "envelope" of precessional amplitude at some intervals (e.g., stages 15-13, 0.6 to $0.5 \mathrm{Ma}$ ). For a single unsmoothed signal, the site 607 $\delta^{18} \mathrm{O}$ record sufficiently resembles the orbital forcing to encourage use of the precessional $\delta^{18} \mathrm{O}$ component as an additional criterion for tuning the Matuyama portion of the record.

\section{TIME SCALE}

In this section, we develop a time scale for the early and middle Pleistocene based on site $607 \delta^{18} \mathrm{O}$ data. First, we refine the Obliquity time scale in the Matuyama portion of the Pleistocene. Then, we reexamine the SPECMAP time scale for the Brunhes Chron and make adjustments in stages 17 and 16 from 0.70 to $0.64 \mathrm{Ma}$.

\section{Matuyama Time Scale}

Following the approach of Imbrie et al. [1984], we tune the $\delta^{18} \mathrm{O}$ record to the direct forcing provided by orbital precession and obliquity (irradiation signals). Orbital eccentricity is not used as a target, but the consequences of tuning to tilt and 
TABLE 5. Evaluation of Three Possible Correlations of Orbital Obliquity and Matuyama $\delta^{18} \mathrm{O}$ Cycles at Site 607

\begin{tabular}{lccc}
\hline & $\begin{array}{c}\text { Obliquity } \\
\text { Time Scale } \\
\text { Translated } \\
\text { Down One Cycle }\end{array}$ & $\begin{array}{c}\text { Obliquity } \\
\text { Time Scale } \\
\text { Match } \\
\text { of Cycles }\end{array}$ & $\begin{array}{c}\text { Obliquity } \\
\text { Time Scale } \\
\text { Translated } \\
\text { Up One Cycle }\end{array}$ \\
\hline $\begin{array}{c}\text { Signal correlation } \\
\left(\delta^{18} \text { O/orbital) }\right.\end{array}$ & 0.82 & $0.85^{*}$ & 0.83 \\
$\begin{array}{c}\text { Correlation of half-cycle length } \\
\text { vs duration }(1.07-1.48 \mathrm{Ma})\end{array}$ & 0.25 & $0.43^{*}$ & -0.44 \\
$\begin{array}{c}\text { Correlation of half-cycle length } \\
\text { vs duration (1.07-1.65 Ma) }\end{array}$ & 0.17 & $0.52^{*}$ & -0.11 \\
\hline
\end{tabular}

\footnotetext{
*Represents the best correlations obtained for all three possibilities given.
}

precession on the phasing of the eccentricity cycle are examined later. Accepting the importance of orbital forcing, we also try to minimize variance at periods other than those of the primary orbital periodicities.

For the portion of the record below the Brunhes/Matuyama boundary, we used the inverse correlation method of Martinson et al. [1982], which correlates a given signal (in this case site $607 \delta^{18} \mathrm{O}$ ) to a reference or "target" curve. To produce a target curve, we normalized the orbital obliquity signal and lagged it 8000 years, and we inverted and normalized the precessional

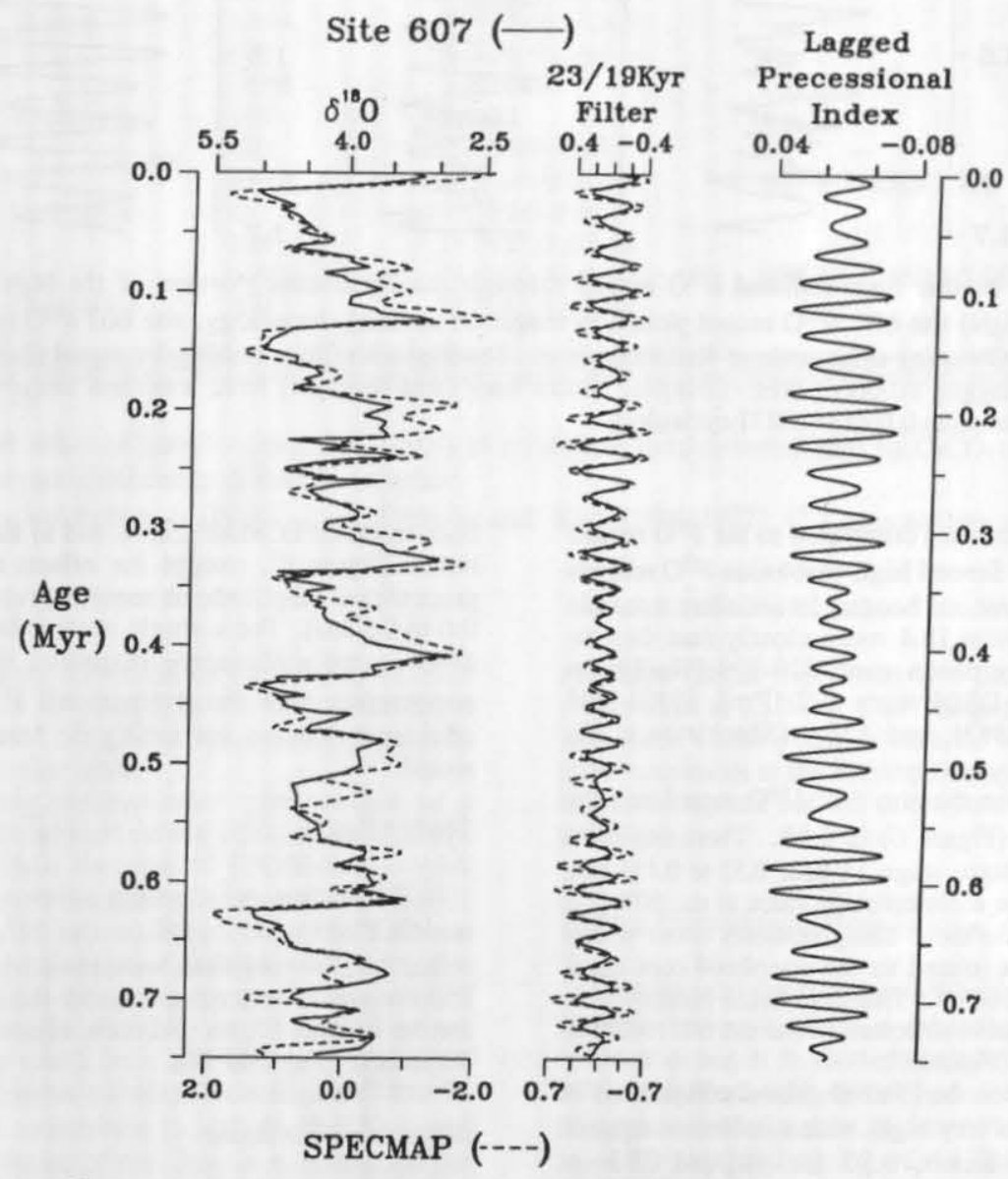

Fig. 6. Records of $\delta^{18} \mathrm{O}$ for the Brunhes Chron: (left to right) site $607 \delta^{18} \mathrm{O}$ record (solid curve) overlaid on SPECMAP $\delta^{18} \mathrm{O}$ stack (dashed curve) from Imbrie et al. [1984], filtered precession component of $\delta^{18} \mathrm{O}$ signals from site 607 (solid curve) and SPECMAP (dashed curve), and lagged orbital precessional index. The precessional filter here (and hereafter) has a central frequency of 0.0477 cycles/kyr and bandwidth $0.0382-0.0573$ cycles/kyr. 


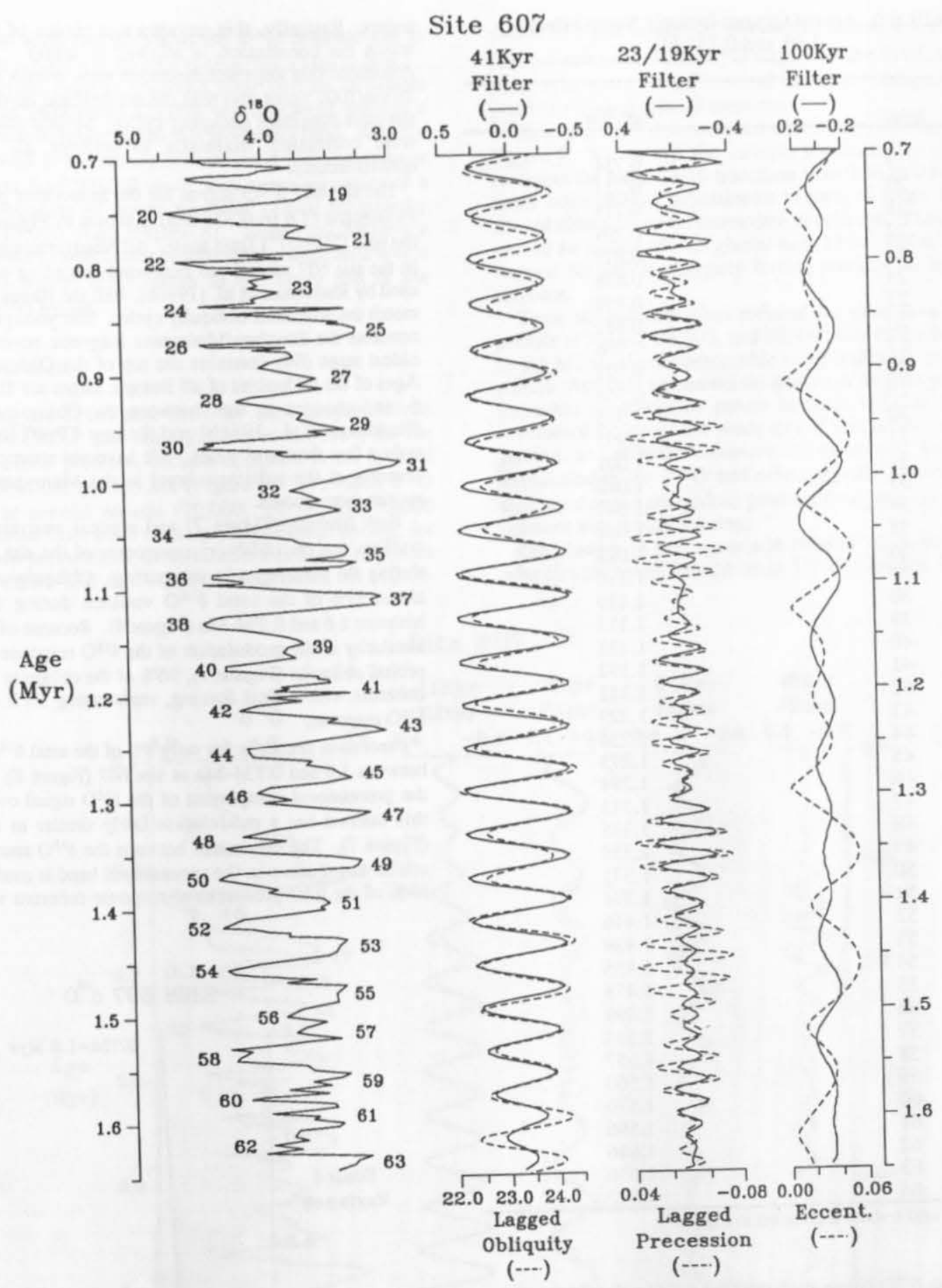

Fig. 7. Site $607 \delta^{18} \mathrm{O}$ data plotted to TP607 time scale for interval $1.65-0.734 \mathrm{Ma}$ (left to rigit) $\delta^{18} \mathrm{O}$ data with numbered isotopic stages, filtered $\delta^{18} \mathrm{O}$ obliquity signal (solid curve) versus lagged orbital obliquity (dashed curve), filtered $\delta^{18} \mathrm{O}$ precessional signal (solid curve) versus lagged orbital precession (dashed curve), and filtered eccentricity signal (solid curve) versus orbital eccentricity (dashed curve). Filters have a central frequency at 41,000 years.

index curve and lagged it 5000 years. Both choices follow values derived in Imbrie et al. [1984]. We then combined these two orbital signals by adding one half the lagged and normalized precessional curve to the lagged and normalized tilt curve. This target curve (called $\mathrm{T}+1 / 2 \mathrm{P}$ ) was chosen to reflect the dominance of tilt in the $\delta^{18} \mathrm{O}$ response but to also allow some tuning to precession. Sensitivity tests showed that this ratio (tilt/precession) could vary through a wide range of values with negligible effect on the results.

We then imposed tie lines in the correlation program at three 
TABLE 6. Ages of Oxygen Isotopic Stages between 1.60 and $0.734 \mathrm{Ma}$

\begin{tabular}{|c|c|}
\hline Stage & Age, $\mathrm{Ma}$ \\
\hline 19 & 0.734 \\
\hline 20 & 0.751 \\
\hline 21 & 0.775 \\
\hline 22 & 0.799 \\
\hline 23 & 0.819 \\
\hline 24 & 0.838 \\
\hline 25 & 0.859 \\
\hline 26 & 0.881 \\
\hline 27 & 0.906 \\
\hline 28 & 0.922 \\
\hline 29 & 0.946 \\
\hline 30 & 0.965 \\
\hline 31 & 0.985 \\
\hline 32 & 1.007 \\
\hline 33 & 1.022 \\
\hline 34 & 1.047 \\
\hline 35 & 1.068 \\
\hline 36 & 1.088 \\
\hline 37 & 1.110 \\
\hline 38 & 1.130 \\
\hline 39 & 1.153 \\
\hline 40 & 1.173 \\
\hline 41 & 1.192 \\
\hline 42 & 1.212 \\
\hline 43 & 1.229 \\
\hline 44 & 1.254 \\
\hline 45 & 1.273 \\
\hline 46 & 1.294 \\
\hline 47 & 1.313 \\
\hline 48 & 1.335 \\
\hline 49 & 1.359 \\
\hline 50 & 1.371 \\
\hline 51 & 1.394 \\
\hline 52 & 1.416 \\
\hline 53 & 1.434 \\
\hline 54 & 1.455 \\
\hline 55 & 1.478 \\
\hline 56 & 1.499 \\
\hline 57 & 1.514 \\
\hline 58 & 1.537 \\
\hline 59 & 1.560 \\
\hline 60 & 1.576 \\
\hline 61 & 1.596 \\
\hline 62 & 1.616 \\
\hline 63 & 1.636 \\
\hline 64 & 1.662 \\
\hline
\end{tabular}

Stages and events are shown in Figure 7.

levels in the $\delta^{18} \mathrm{O}$ curve, each marking a $\mathrm{K} / \mathrm{Ar}$-dated magnetic reversal: the Brunhes/Matuyama boundary $(0.73 \mathrm{Ma})$, the bottom of the Jaramillo subchron $(0.97 \mathrm{Ma})$, and the top of the Olduvai subchron (1.66 Ma). With only this initial guidance, the inverse technique reproduced the same match of $\delta^{18} \mathrm{O}$ cycles to orbital obliquity as previously determined by Ruddiman et al. [1986c].

As the inverse-correlation method tuned to progressively higher-frequency (precessional) components of the orbital target signal, subjective decisions arose as to what degree of distortion (stretching and compression) of the original record to accept. Basically, this amounts to a choice of the resolution which the correlation is allowed to attain. We accepted distortions that kept sedimentation rates within the range 2 to $10 \mathrm{~cm} / 1000$ years and that did not degrade obvious power in the more dominant obliquity cycles. Several shorter intervals were correlated manually to achieve all these goals simultaneously.

The site $607 \delta^{18} \mathrm{O}$ signal for the Matuyama portion of the Pleistocene (1.6 to $0.734 \mathrm{Ma}$ ) is shown in Figure 7 plotted to the new ("TP607") time scale. All Matuyama-age $\delta^{18} \mathrm{O}$ stages in the site 607 record are numbered according to the scheme used by Ruddiman et al. [1986b], with the stages numbered to match the dominant obliquity cycles. The youngest stage (19) contains the Brunhes/Matuyama magnetic reversal, and the oldest stage (64) contains the top of the Olduvai subchron. Ages of the midpoints of all isotopic stages are listed in Table 6 , and changes in age between the Obliquity time scale [Ruddiman et al., 1986b] and the new TP607 time scale are only a few thousand years. We have not attempted to name features at the substage level in the Matuyama; that will require more records.

Both filtering (Figure 7) and spectral analysis (Figure 8) confirm that the obliquity component of the site $\delta^{18} \mathrm{O}$ signal during the Matuyama is very strong. Obliquity accounts for about $55 \%$ of the total $\delta^{18} \mathrm{O}$ variance during the interval between 1.6 and $0.734 \mathrm{Ma}$ (Figure 8). Because of the general similarity in the modulation of the $8^{18} \mathrm{O}$ response and that of orbital obliquity (Figure 7), 96\% of the obliquity response is coherent with orbital forcing, representing $53 \%$ of the total $\delta^{18} \mathrm{O}$ response.

Precession accounts for only $8 \%$ of the total $\delta^{18} \mathrm{O}$ response between 1.6 and $0.734 \mathrm{Ma}$ at site 607 (Figure 8). However, the precessional component of the $\delta^{18} \mathrm{O}$ signal over some of this interval has a modulation fairly similar to the forcing (Figure 7). The coherence between the $8^{18} \mathrm{O}$ record and the orbital target curve in the precessional band is moderate, with $64 \%$ of the total precessional response coherent with orbital

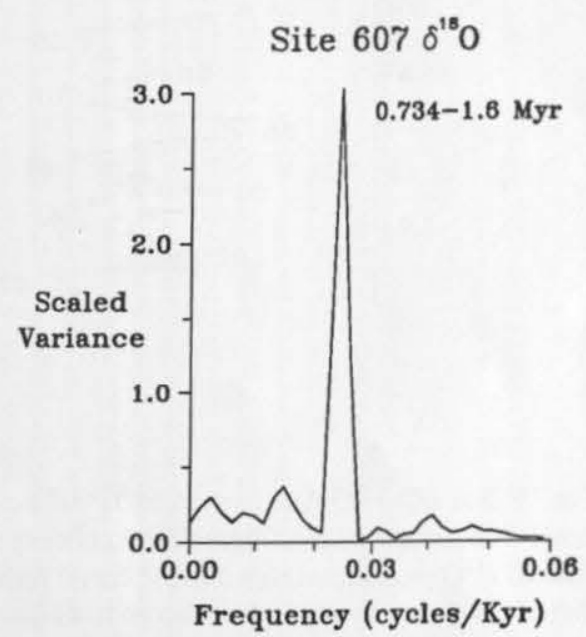

Fig. 8. Spectra of site $607 \delta^{18} \mathrm{O}$ record derived from TP607 time scale during interval 1.6-0.734 Ma. Spectral analyses here (and hereafter) followed the Blackman-Tukey technique with a Hamming window, 1/3 lag, resampling interval of 3400 years, and $\mathrm{N}=217$. 
forcing. This adds another $5 \%$ to the $\delta^{18} \mathrm{O}$ response that is coherent with orbital forcing after tuning, for a total of $60 \%$.

No distinctive peak is observed near periods of orbital eccentricity at 94,000 and 125,000 years; instead, there is a broad minimum in power across this frequency band. Roughly $13 \%$ of the total $\delta^{18} \mathrm{O}$ variance is associated with responses at periods longer than 100,000 years, with some suggestion of a small concentration of power near the orbital eccentricity period of 413,000 years (Figure 8). Some low-frequency contribution may result from nonstationarity associated with a drift toward higher $\delta^{18} \mathrm{O}$ values in the upper part of the Matuyama $\delta^{18} \mathrm{O}$ record.

\section{Brunhes Time Scale}

In merging the TP607 time scale for the Matuyama chron with the SPECMAP time scale [Imbric et al., 1984] for the Brunhes, several problems became apparent in the interval between about 0.8 and $0.6 \mathrm{Ma}$ (Figure 9). We found $8^{18} \mathrm{O}$ responses at several periods $(70,000,54,000$, and 30,000 years) different from those of the primary orbital forcing; for the latter two periodicities, these were the strongest responses within the entire $1.65 \mathrm{~m} . \mathrm{y}$. of the record. Also, the 41,000- year $\delta^{18} \mathrm{O}$ signal weakened substantially across this interval, in part because interglacial $\delta^{18} \mathrm{O}$ stage 17 in the SPECMAP time scale is centered on an interval for which obliquity forcing predicts a (lagged) glacial response.

These problems were reduced with the adjustments shown in Figure 9. We moved the isotopic transition that appears to represent the stage $17 / 16$ transition from 0.66 to $0.68 \mathrm{Ma}$ and made other smaller adjustments of parts of stage 16 and 17 toward older ages to accommodate this change. These changes moved the middle of interglacial stage 17 into the middle of an interval for which obliquity forcing predicts an interglacial response.

These adjustments also reduced the excessive power at periods of $70,000,54,000$, and 30,000 years in the interval 0.8 to $0.6 \mathrm{Ma}$ to levels comparable to several other parts of the record. And they increased the amount of 41,000-year power, increased precessional power between 0.75 and $0.6 \mathrm{Ma}$, maintained the excellent phase lock of precession with orbital forcing, and slightly enhanced the agreement between the modulation of the $\delta^{18} \mathrm{O}$ and orbital signals. These changes thus transformed anomalous power at three periods into power coherent with orbital forcing.

Our changes in part agree with those of Black et al. [1988], who also proposed that the stage $17 / 16$ transition should date

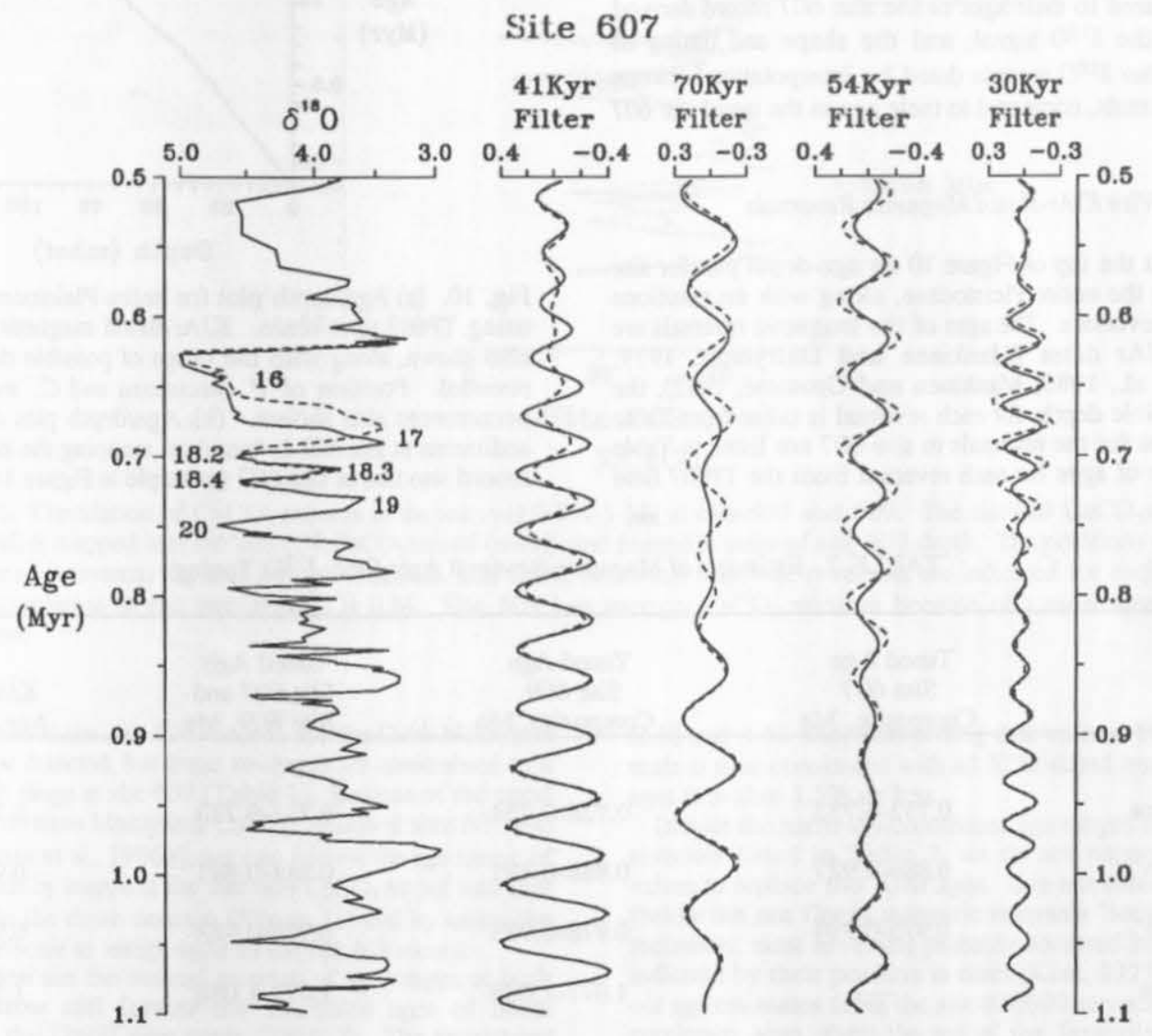

Fig. 9. Site $607 \delta^{18} \mathrm{O}$ data for interval 1.1-0.5 Ma plotted to two time scales. Data from the Matuyama Chron $(>0.734 \mathrm{Ma})$ are plotted according to the TP607 time scale in both versions. Data from Brunhes Chron are plotted to SPECMAP time scale for the version in dashed lines and to adjusted SPECMAP time scale for the version in solid lines. Shown, from left to right, are the $\delta^{18} \mathrm{O}$ record and filtered $\delta^{18} \mathrm{O}$ signal at 41,000 years, 70,000 years, 54,000 years, and 30,000 years. SPECMAP data are resampled at a 2000-year time step. 
some 15,000 years older than shown in the SPECMAP time scale of Imbrie et al [1984]. Below stage 17, however, our adjustments disagree with that of Black et al., who redated the high-amplitude oscillations of stage 18 (events 18.2, 18.3, and 18.4) to older levels, altering the SPECMAP time scale by compressing all of stage 18 and upper stage 19 against the lower limit of the Brunhes/Matuyama boundary. In contrast, our changes retain the SPECMAP time scale from event 18.2 through the Brunhes/Matuyama boundary; our adjustments all occur above the middle of event 18.2.

At this point, we do not suggest formalizing our adjustments as a new time scale. The reason for caution is that the single-peaked isotopic stage 17 in the site 607 record looks different from the double-peaked stage 17 in the SPECMAP composite and in several individual cores. It seems unwise to base a time scale revision on an atypical feature. Still, we recommend that close attention be paid in future efforts with stacked multicore composites to the likelihood that the stage $17 / 16$ is older than estimated by SPECMAP.

\section{EVALUATION OF TP607 TIME SCALE}

We evaluate the TP607 time scale by comparison with two kinds of evidence: the ages of magnetic reversals from $\mathrm{K} / \mathrm{Ar}$ dating, compared to their ages in the site 607 record derived from tuning the $\delta^{18} \mathrm{O}$ signal; and the shape and timing of features in other $\delta^{18} \mathrm{O}$ records dated by interpolation between magnetic reversals, compared to their age in the tuned site 607 $\delta^{18} \mathrm{O}$ record.

\section{Comparison With K/Ar-Dated Magnetic Reversals}

We show at the top of Figure 10 an age-depth plot for site 607 spanning the entire Pleistocene, along with the positions of magnetic reversals. The ages of the magnetic reversals are based on K/Ar dates [Mankinen and Dalrymple, 1979; Mankinen et al., 1980; Mankinen and Grommé, 1982]; the range of possible depths for each reversal is taken from Table 4. Age ranges for the reversals in site 607 are listed in Table 7. The range of ages for each reversal from the TP607 time scale agrees closely with the $\mathrm{K} / \mathrm{Ar}$ dates, particularly at the narrowly constrained Brunhes/Matuyama boundary and top of the Olduvai subchron.

The top and bottom of the Jaramillo subchron are not as
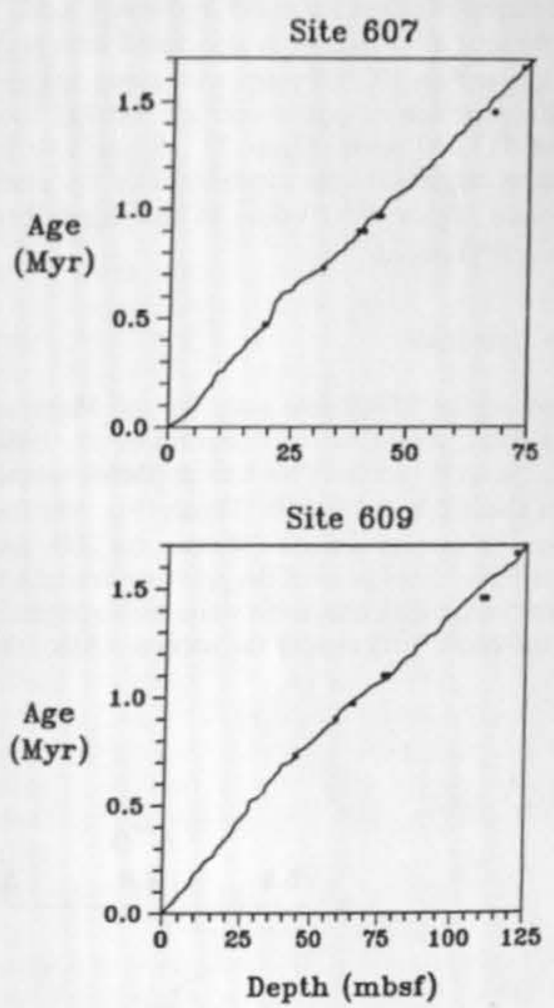

Fig. 10. (a) Age/depth plot for entire Pleistocene at site 607, using TP607 time scale. K/Ar-dated magnetic reversals are also shown, along with the range of possible depths for each reversal. Position of $P$. lacunosa and $C$. macintyrei last occurrences also shown. (b) Age/depth plot of Pleistocene sediments at site 609 is based on mapping the site $609 \mathrm{CaCO}_{3}$ record into that of site 607 (example in Figure 11).

TABLE 7. Estimates of Magnetic Reversal Ages From $\delta^{18} \mathrm{O}$ Tuning

\begin{tabular}{lcccc}
\hline & $\begin{array}{c}\text { Tuned Age } \\
\text { Site 607 } \\
\text { Composite, Ma }\end{array}$ & $\begin{array}{c}\text { Tuned Age } \\
\text { Site 609 } \\
\text { Composite, Ma }\end{array}$ & $\begin{array}{c}\text { Tuned Age } \\
\text { Site 607 and } \\
\text { Site 609, Ma }\end{array}$ & $\begin{array}{c}\text { K/Ar } \\
\text { Age, Ma }\end{array}$ \\
\hline $\begin{array}{c}\text { Brunhes/ } \\
\text { Matuyama }\end{array}$ & $0.732-0.733$ & $0.728-0.734$ & $0.732-0.733$ & $0.73^{*}$ \\
$\begin{array}{c}\text { Top of } \\
\text { Jaramillo } \\
\text { Bottom of } \\
\text { Jaramillo }\end{array}$ & $0.886-0.927$ & $0.888-0.891$ & $0.888-0.891$ & 0.90 \\
$\begin{array}{c}\text { Cobb } \\
\text { Mountain }\end{array}$ & $0.975-0.994$ & $0.978-0.983$ & $0.978-0.983$ & 0.97 \\
$\begin{array}{c}\text { Top of } \\
\text { Olduvai }\end{array}$ & -1.653 & $1.077-1.088$ & $1.077-1.088$ & 1.10 \\
\hline
\end{tabular}

*Tuned estimate of Imbrie et al. [1984] is $0.734 \mathrm{Ma}$.

Talculated by interpolating age of magnetic anomalies on seafloor relative to K/Ar-dated top and bottom of Matuyama Chron. 


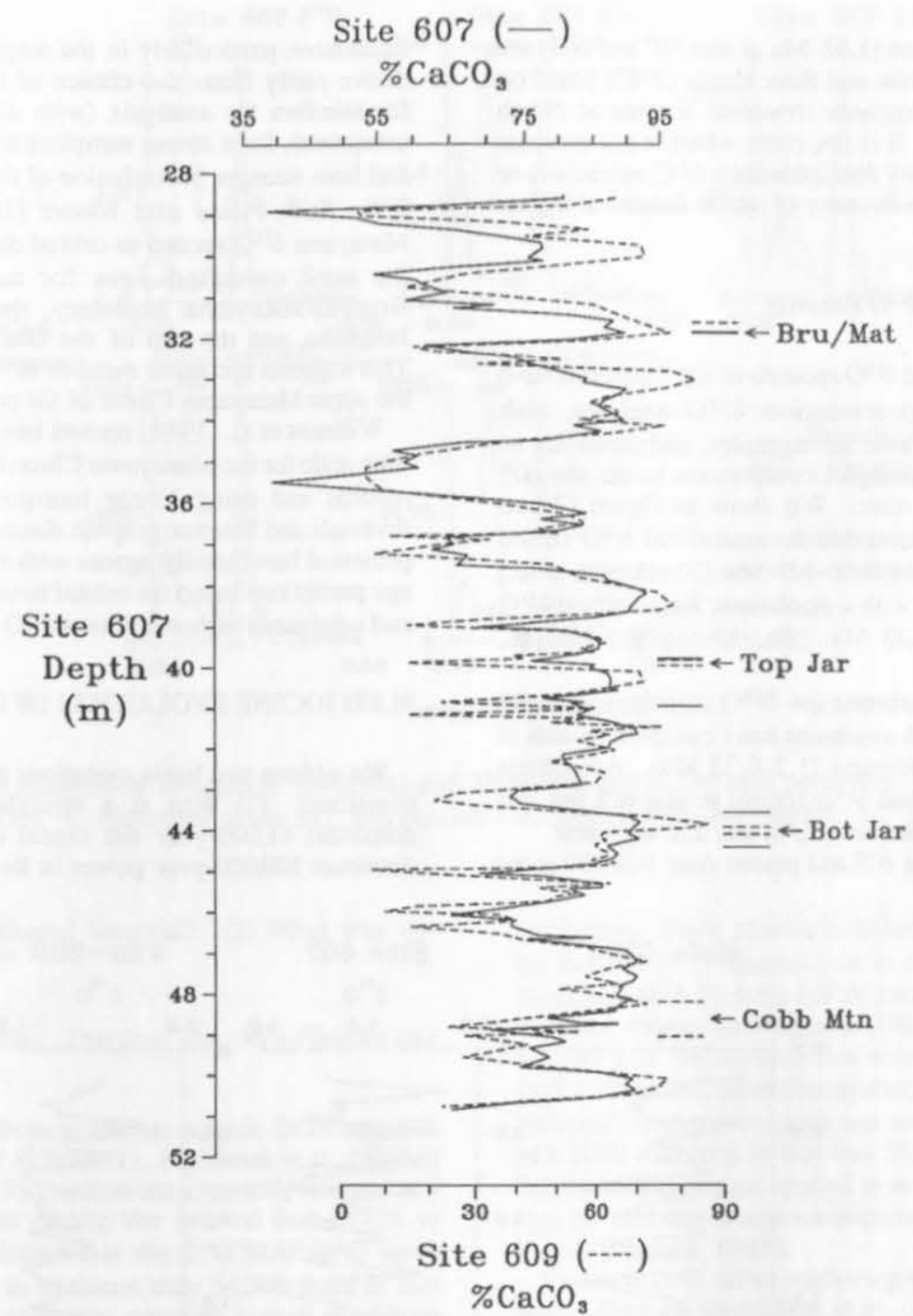

Fig. 11. Correlation of $\mathrm{CaCO}_{3}$ records in the interval 0.7-1.1 Ma at sites 607 and 609. The site $609 \mathrm{CaCO}_{3}$ record (dashed) is mapped into the site $607 \mathrm{CaCO}_{3}$ record (solid) and plotted in units of site 607 depth. The positions of the Brunhes-Matuyama, top and bottom Jaramillo, and Cobb Mountain magnetic reversals are indicated for each site. The correlation of the two signals is 0.84 . Site 609 has stronger $\mathrm{CaCO}_{3}$ minima because of a more northerly location.

closely defined in the site 607 record, and the Cobb Mountain event was not detected, but these reversals are constrained to a narrow depth range at site 609 (Table 4). Because of the good correlations between Matuyama $\mathrm{CaCO}_{3}$ records at sites 607 and 609 [Ruddiman et al., 1986b], we can narrow the age range of these reversals by mapping the site $609 \mathrm{CaCO}_{3}$ record into that of site 607 in the depth domain (Figure 11) and by using the site 607 time scale to assign ages to the site 609 record.

We can then use the mutual overlap of age ranges at both sites to narrow still further the estimated ages of these reversals in the TP607 time scale (Table 7). The agreement with the $\mathrm{K} / \mathrm{Ar}$ estimates is within $1 \%$ for all reversals except the Cobb Mountain event. The estimate of $1.085 \mathrm{Ma}$ for the Cobb Mountain event from the TP607 time scale differs with the mean value of $1.10 \mathrm{Ma}$ from Mankinen and Grommé [1982] by only $1.5 \%$ and matches one of two age clusters
(1.08 and $1.12 \mathrm{Ma}$ ) comprising that value. The TP607 time scale is thus consistent with all $\mathrm{K} / \mathrm{Ar}$-dated magnetic reversal ages to within $1.5 \%$ or less.

Despite the narrowly constrained age ranges for the magnetic reversals listed in Table 7, we do not propose using these values to replace the $\mathrm{K} / \mathrm{Ar}$ ages. It is not clear at what depth (below the sea floor) magnetic reversals "lock in" to marine sediments; most reversals probably occurred later in time than indicated by their position in cores [Kent, 1973]. If, however, our age estimates from the site $607 / 609$ records are viewed as maximum ages, then the top of the Jaramillo and Olduvai subchrons would have to be somewhat younger than the K/Ar ages.

The $P$. lacunosa extinction dates to $0.463 \mathrm{Ma}$ in site 607 , in good agreement with the age obtained previously [Thierstein et al., 1977; Imbrie et al., 1984]. Our estimates for the age of 
the C. macintyrei extinction (1.52 Ma at site 607 and 609) are older than those of Backman and Shackleton [1983] based on interpolation between magnetic reversal datums at North Atlantic DSDP site 552. It is not clear whether our estimate dates an earlier evolutionary disappearance of $C$. macintyrei or reflects the time-transgressiveness of some datums at higher latitudes.

\section{Comparison With Other $8^{18} \mathrm{O}$ Records}

Relatively few published $\delta^{18} \mathrm{O}$ records of the Matuyama have the combination of high-resolution $\delta^{18} \mathrm{O}$ analyses, high sedimentation rates, magnetic stratigraphy, and continuity of record necessary for meaningful comparison to the site 607 record and TP607 time scale. We show in Figure 12 two records: site 552 , with a benthic foraminiferal $\delta^{18} \mathrm{O}$ record spanning 1.2-0.73 Ma and 1.66-1.5 Ma [Shackleton et al., 1984] and core V28-239, with a planktonic foraminiferal $\delta^{18} \mathrm{O}$ record spanning 1.66-0.73 Ma. [Shackleton and Opdyke, 1976].

The close agreement between the $\delta^{18} \mathrm{O}$ signals at sites 607 and 552 indicates that both sequences have complete records of the upper part of the Matuyama (1.2-0.73 Ma). Age offsets between the orbitally tuned $\delta^{18} \mathrm{O}$ record at site 607 and that interpolated from magnetic reversals at site 552 are minor.

Agreement between site 607 and piston core V28-239 is not impressive, particularly in the amplitude matches. This may derive partly from the choice of benthic versus planktonic foraminifera for analysis (with different local temperature overprints), from lower sampling resolution in core V28-239, and from stronger bioturbation of the $8^{18} \mathrm{O}$ signal at core V 28 . 239. Still, Pisias and Moore [1981] tuned the V28-239 Matuyama $\delta^{18} \mathrm{O}$ record to orbital obliquity and derived nearly the same estimated ages for magnetic reversals at the Brunhes/Matuyama boundary, the top and bottom of the Jaramillo, and the top of the Olduvai as those in Table 7. This suggests the same number of 41,000 -year oscillations in the upper Matuyama Chron of the two cores.

Williams et al. [1988] named isotopic stages and proposed a time scale for the Matuyama Chron based on four stacked $8^{18} 0$ records and using linear interpolation between magnetic reversals and biostratigraphic datums. The TP607 time scale presented here broadly agrees with theirs, but we make explicit age predictions based on orbital tuning of a verifiably complete and continuous high-resolution $8^{18} \mathrm{O}$ record.

\section{PLEISTOCENE EVOLUTION OF CLIMATIC RESPONSES}

We address two basic questions about the mid-Pleistocene transition: (1) Was it a straightforward shift from the dominant 41,000-year tilt signal of the Matuyama to the dominant 100,000-year power in the Brunhes, or did rhythms

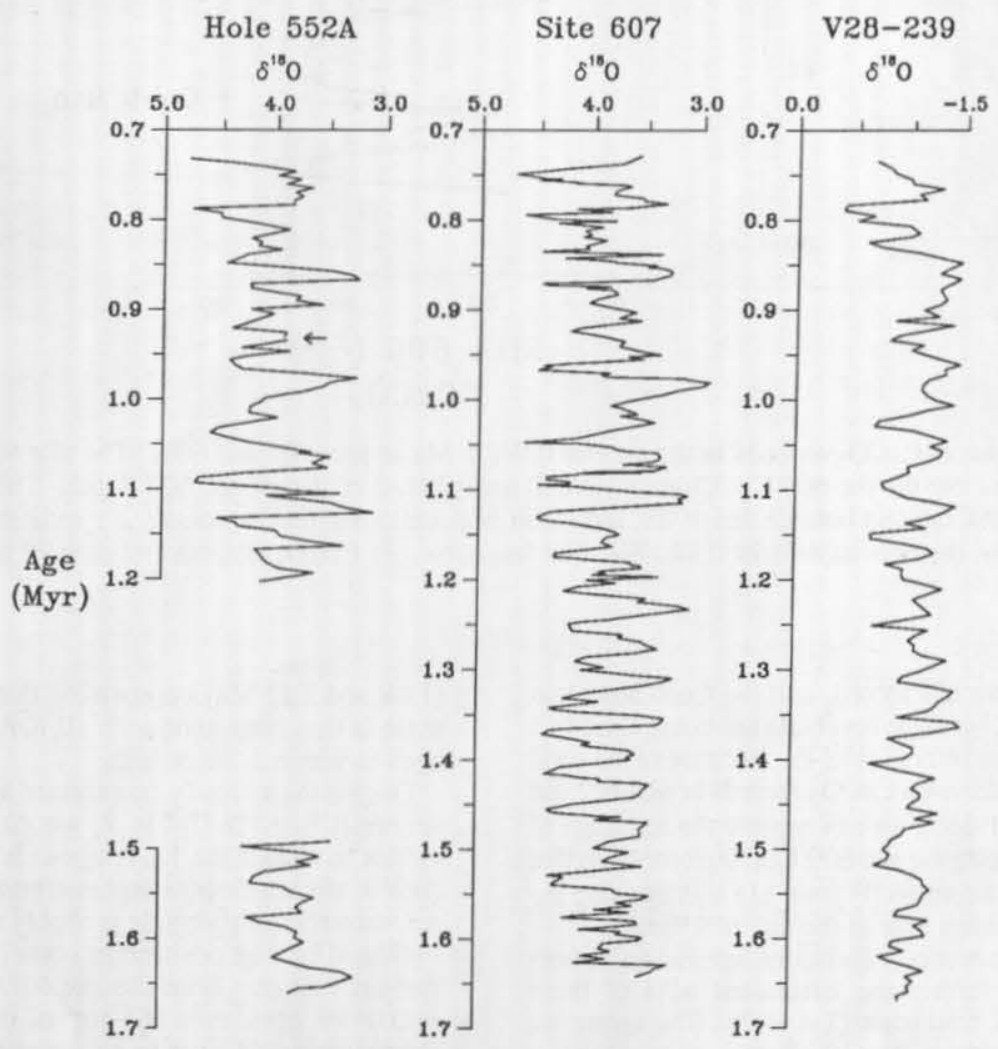

Fig. 12. Comparison of site 607 upper Matuyama $\delta^{18} \mathrm{O}$ record plotted to TP607 time scale (center) with $\delta^{18} \mathrm{O}$ records plotted to magnetic reversal chronology: North Atlantic site 552 (left) and western equatorial Pacific piston core V28-239 (right). The gap in the site 552 record is due to a disturbed core. The arrow marks the position of a core break in the record from site 552 . 


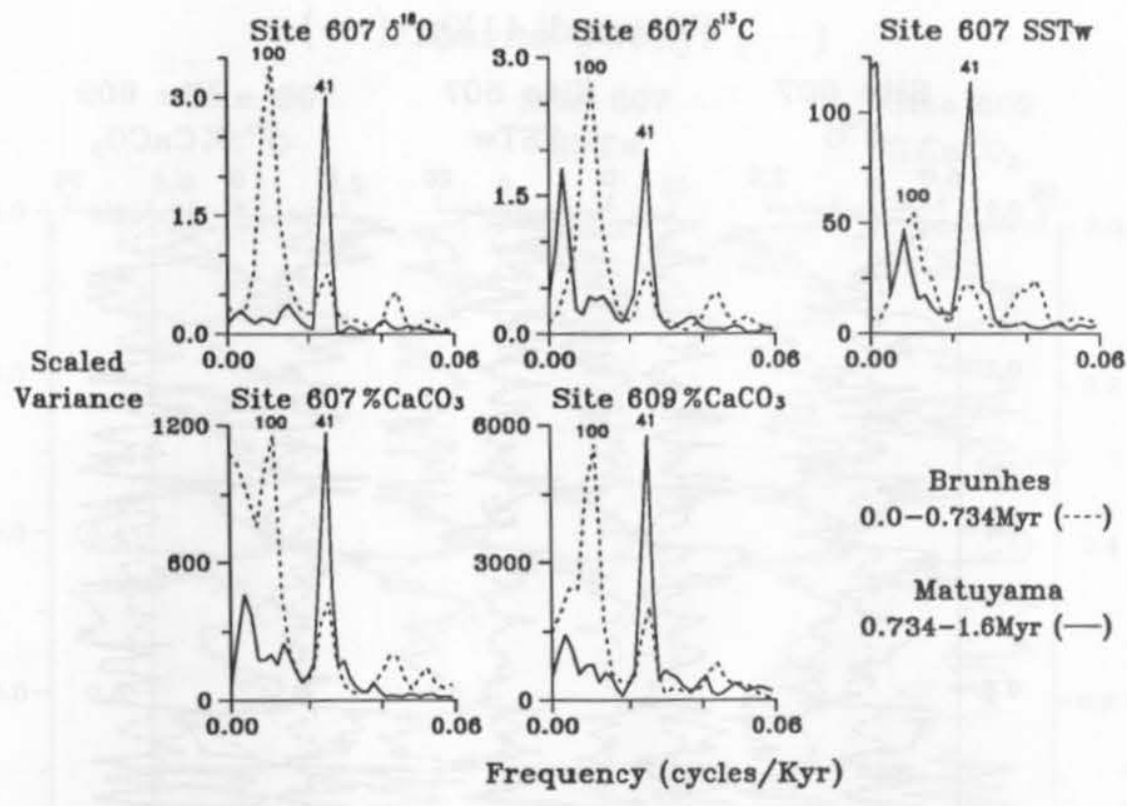

Fig. 13. Spectral analysis of Brunhes (0.734-0 Ma) and Matuyama (1.6-0.734 Ma) portions of the Pleistocene for five records: $\delta^{18} \mathrm{O}, \delta^{13} \mathrm{C}$, estimated winter SST, and percent $\mathrm{CaCO}_{3}$ at site 607 ; and percent $\mathrm{CaCO}_{3}$ at site 609 .

emerge during a transitional interval? (2) What was the duration of the transition?

\section{Anomalous Periodicities During the Mid-Pleistocene Transition}

In a record compiled from northeast Atlantic DSDP site 552 and piston core K708-7 (Figure 1), Ruddiman et al. [1986a] detected a sequence of SST oscillations apparently centered at a rhythm of 54,000 years during the interval from 0.775 to $0.625 \mathrm{Ma}$. They also found that the SPECMAP $\delta^{18} \mathrm{O}$ stack showed some increase in variance near 54,000 years at this time. Because orbital obliquity contains a small insolation forcing component at this period [Berger, 1978], they suggested that this SST signal could be an insolation-driven response amplified within the climate system. However, they cautioned that these oscillations could be an artifact of an incorrect time scale or of incorrect transfer of the SPECMAP time scale.

The results in Figure 9 demonstrate that a small but plausible adjustment to the SPECMAP time scale greatly reduced the amount of 54,000-year power (and 30,000-year and 70,000 -year power) in the $\delta^{18} \mathrm{O}$ record of site 607 . Other tests (not shown) show that large concentrations of power at $54,000,70,000$, and 30,000 years in this same interval of the site $607 \mathrm{CaCO}_{3}$ and SST records were also substantially reduced by this change. As a result, there is no evidence of unusually strong periodic responses other than those at the primary orbital rhythms during the mid-Pleistocene transition.

\section{Orbital Periodicities Through the Pleistocene}

The central focus of this paper is the timing of the change in response at high latitudes of the northern hemisphere from 41,000 -year Matuyama variations to 100,000 -year Brunhes oscillations. Some studies have favored a rapid transition. On the basis of $8^{18} \mathrm{O}$ fluctuations in core V28-239 (Figure 12), Shackleton and Opdyke [1976] placed the change at about 0.8 $\mathrm{Ma}$, and Pisias and Moore [1981] suggested that strong 100,000 -year fluctuations first occurred abruptly after $0.9 \mathrm{Ma}$. Prell [1982] concluded that an abrupt switch in "mode" of $8^{18} \mathrm{O}$ variation (changes in mean and standard deviation) in DSDP hole $502 \mathrm{~B}$ occurred in less than 50,000 years at about $0.9 \mathrm{Ma}$. Statistical techniques applied to several $\delta^{18} \mathrm{O}$ records suggest that the mid-Pleistocene transition was an abrupt "jump" at $0.9 \mathrm{Ma}$ [Maasch, 1988].

Evidence from other studies argues for a later, more gradual shift. Data of Ruddiman et al. [1986b] indicate near-total dominance of 41,000 -year power at site 607 until very late in the Matuyama Chron, with much of the transition to 100,000 year power thus consigned to the Brunhes Chron. Imbrie [1985] found that 100,000 -year power almost doubled from the interval $0.78-0.4 \mathrm{Ma}$ to the interval $0.4-0 \mathrm{Ma}$. Ruddiman et al. [1986a] noted a similar doubling of 100,000-year power during the same time period in the composite northeast Atlantic SST record cited above.

With high-resolution $\delta^{18} \mathrm{O}$ data at site 607 and a time scale spanning the entire Pleistocene, we can further address this problem. In addition, we can examine the shift in power in the other proxy indicators: $8^{13} \mathrm{C}$, percent $\mathrm{CaCO}_{3}$ and estimated SST at site 607 and percent $\mathrm{CaCO}_{3}$ at site 609. Spectral analysis of these signals (Figure 13) shows the nearly total change in concentration of orbital power from the Matuyama Pleistocene (1.60 to $0.735 \mathrm{Ma})$ to the Brunhes ( 0.735 to 0 $\mathrm{Ma}$.

We choose to present band-pass filtered versions of the records to portray most clearly the nature of the changes (Figures 14-18). Sensitivity tests show that filtering smooths very abrupt changes to some extent, but the fact that filtered signals can be directly overlaid on the original data at least permits direct visual evaluation of the success of the filtering 

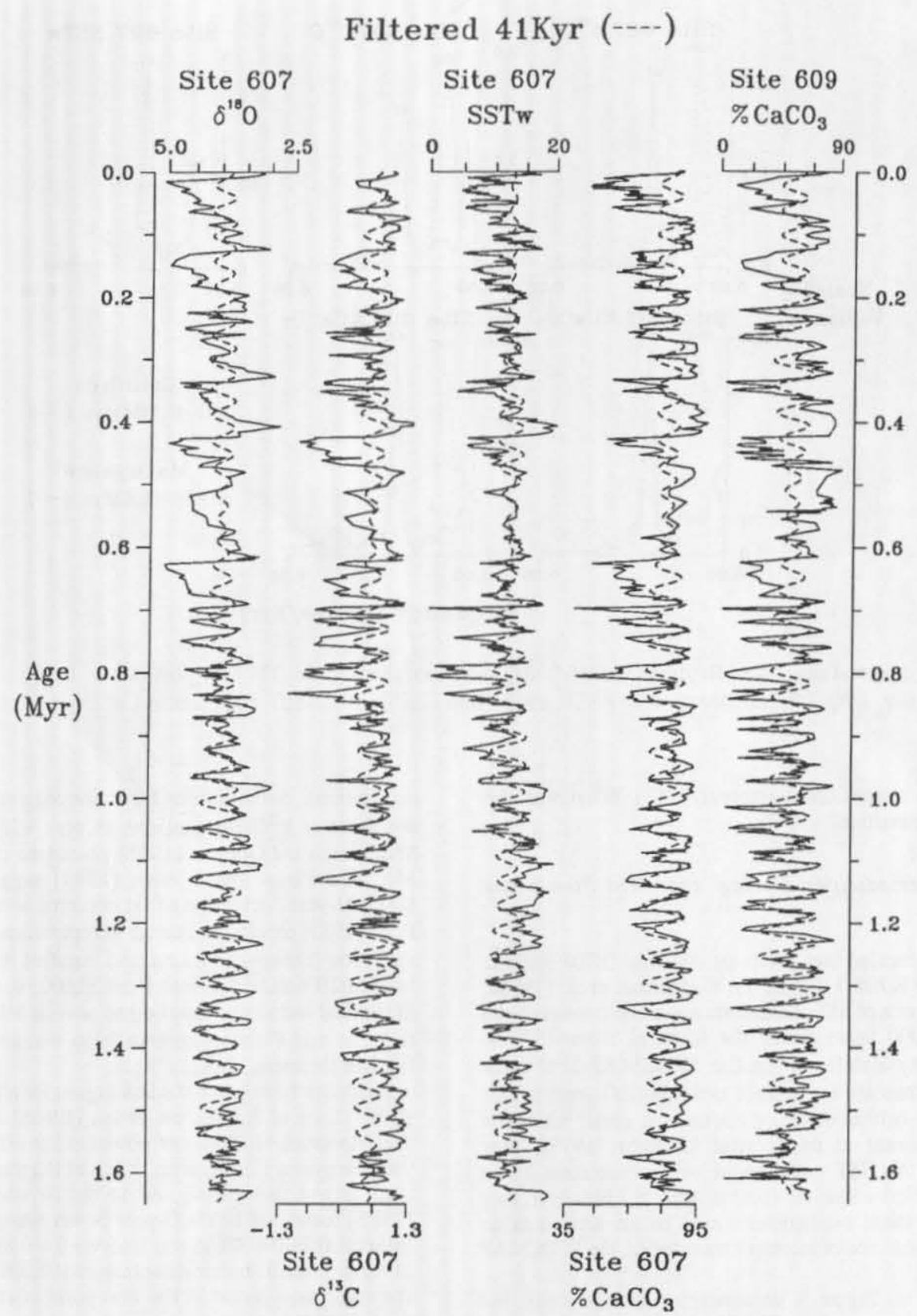

Fig. 14. Overlays of filtered 41,000-year signals (dashed line) on original records (solid line) of site $607 \delta^{18} \mathrm{O}, \delta^{13} \mathrm{C}$, SST, and percent $\mathrm{CaCO}_{3}$ and of site 609 percent $\mathrm{CaCO}_{3}$ for the last $1.65 \mathrm{~m} . \mathrm{y}$.

process and thus the actual rates of change. In effect, the filtered records set an upper limit on the rates of change.

Obliquity. All five records filtered at the central frequency of orbital obliquity (Figure 14) show dominant 41,000-year power in the Matuyama Chron, giving way to weaker power in the Brunhes Chron. The $\delta^{18} \mathrm{O}$-based time scale produces strong 41,000-year oscillations in all five records through the Matuyama portion of the Pleistocene, and all of these signals are in phase to within $10^{\circ}(1100$ years) or less (Table 8$)$. The mid-Pleistocene decline in 41,000-year power varies among the records, beginning as early as $1.1 \mathrm{Ma}$ in the $\delta^{18} \mathrm{O}$ record and as late as $0.7 \mathrm{Ma}$ in the $\delta^{13} \mathrm{C}$ and $\mathrm{CaCO}_{3}$ records. In all records, a minimum in variance is reached at $0.55 \mathrm{Ma}$, with subsequent reemergence of moderate power. In all five records, the 41,000 -year signals are also in phase to within $20^{\circ}(2200$ years) or less during the Brunhes Chron (Table 8).

The 100,000-year ("eccentricity") power. The amplitude of the filtered 100,000-year signals for all five records increased markedly from the Matuyama to the Brunhes Chron (Figure $15)$. Shorter intervals of increased 100,000 -year power are 


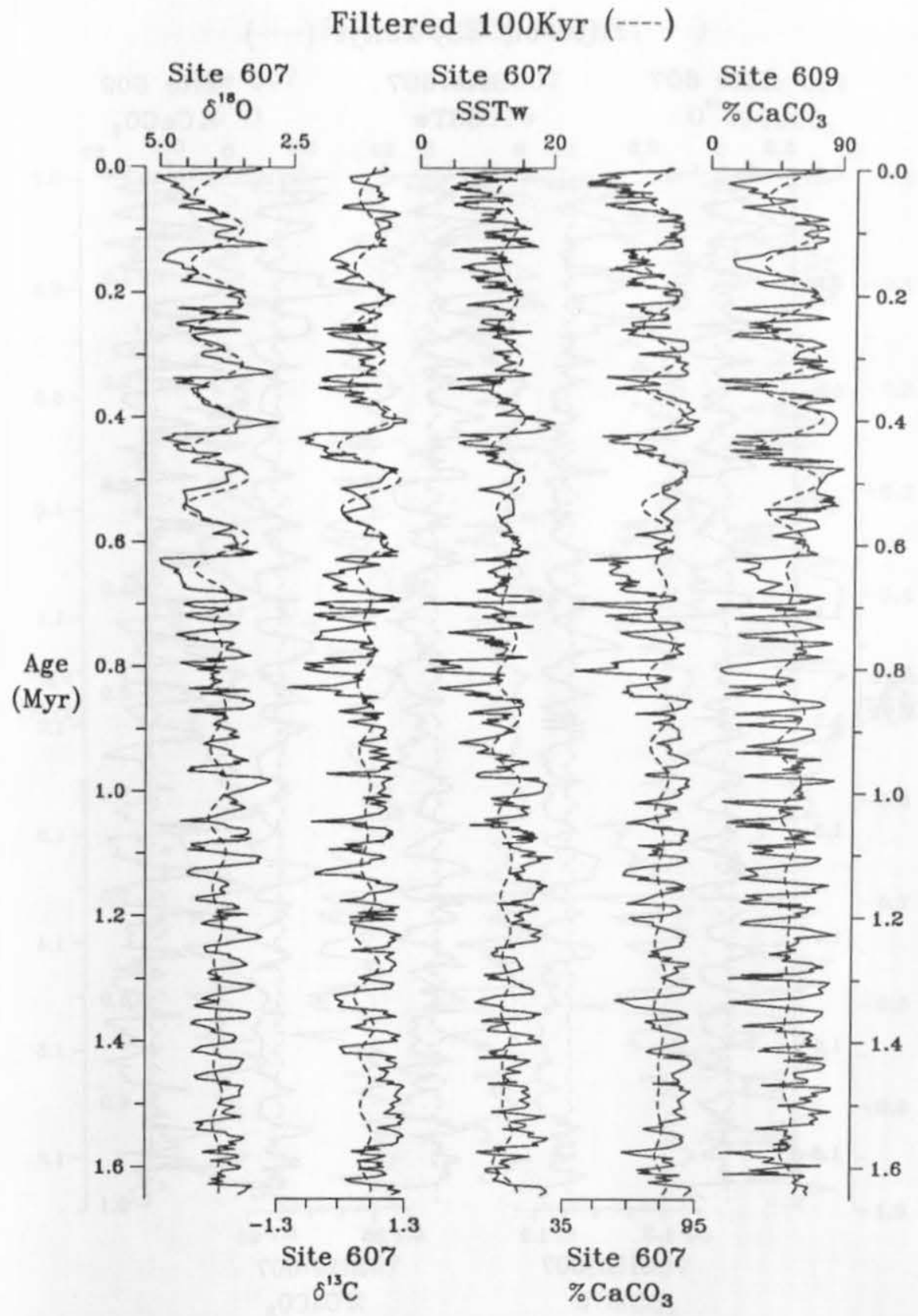

Fig. 15. Overlays of filtered 100,000-year signals (dashed line) on original records (solid line) of site $6078^{18} \mathrm{O}$, $\delta^{13} \mathrm{C}$, SST, and percent $\mathrm{CaCO}_{3}$ and of site 609 percent $\mathrm{CaCO}_{3}$ for the last 1.65 m.y. The eccentricity filter has a central frequency of 0.0103 cycles/ $\mathrm{kyr}$ and bandwidth $0.008-0.0127 \mathrm{cycles} / \mathrm{kyr}$.

evident during the Matuyama, but the timing of these intervals differs considerably among the various parameters, and comparisons of the filtered and original signals do not show the kind of convincing 100,000-year signal that developed during the Brunhes. The temporary increase in 100,000-year $\delta^{18} \mathrm{O}$ variance near $1.0 \mathrm{Ma}$ appears to be linked to a brief shift toward lighter isotopic values (stages 33 to 31 ), but this is opposite to the association of 100,000 -year power with a trend toward heavier $8^{18} \mathrm{O}$ values during the Brunhes. In general, there is remarkably little evidence in these records of significant 100,000 -year power during most of the Matuyama Chron.

By $0.9 \mathrm{Ma}, 100,000$-year power in all five signals begins for the first time to approach or achieve a phase lock with orbital eccentricity (Figure 7). Although 100,000-year power remained weak, this phase lock suggests that the climate system had begun to develop the typical 100,000-year power of the Brunhes Chron. Records of $\delta^{18} \mathrm{O}$ in some regions reached very heavy values in isotopic stage 22 (at $0.8 \mathrm{Ma}$ ), perhaps indicating greater increases in 100,000-year power in 


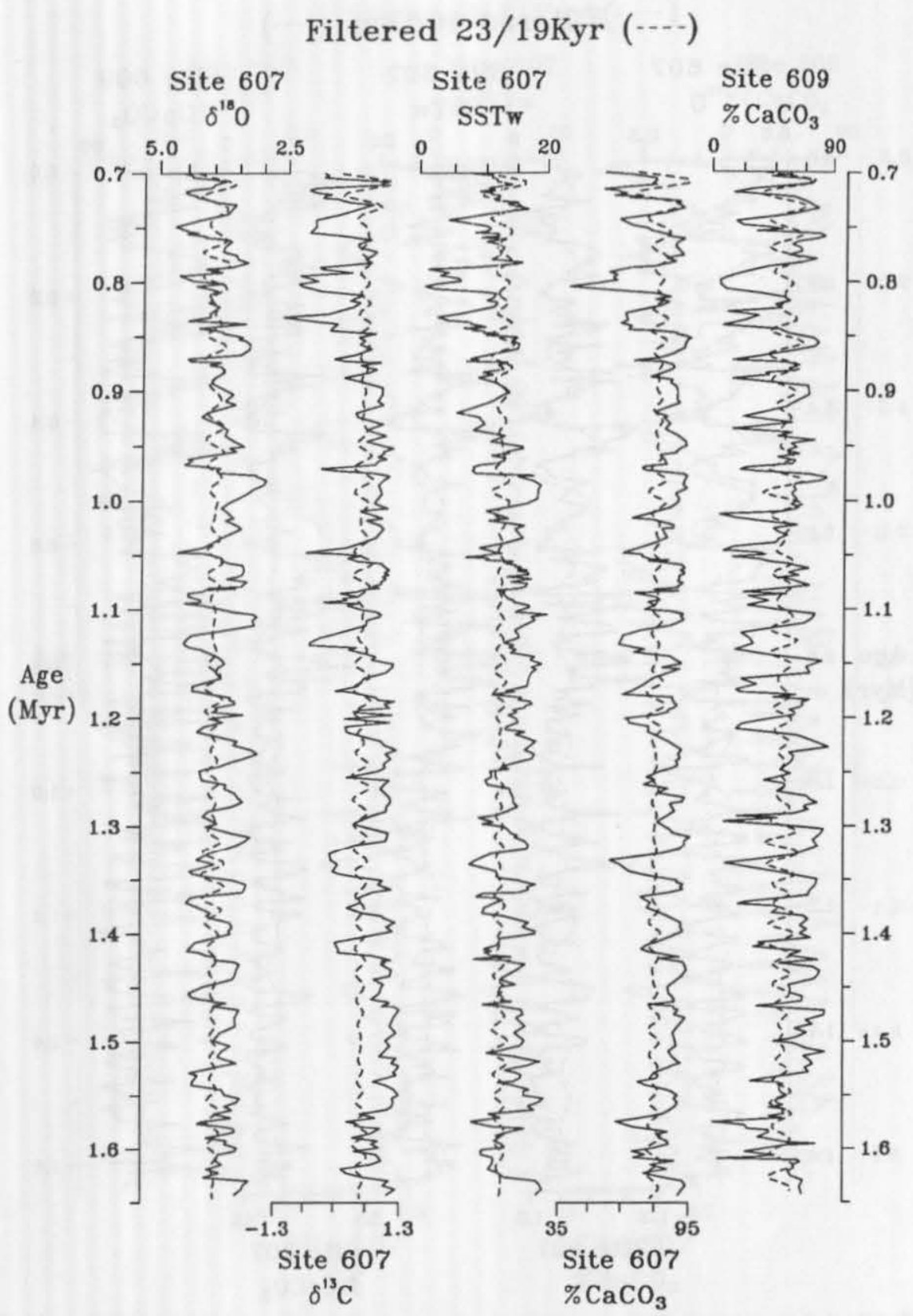

Fig. 16. Overlays of filtered 23,000/19,000-year signals (dashed line) on original records (solid line) of site 607 $\delta^{18} \mathrm{O}, \delta^{13} \mathrm{C}$, SST, and percent $\mathrm{CaCO}_{3}$ and of site 609 percent $\mathrm{CaCO}_{3}$ for the early Pleistocene (1.65-0.734 Ma).

those records, but North Atlantic sites 607 and 552 record a less extreme glaciation (Figure 12) and only moderate 100,000-year power.

Stronger and more convincing 100,000-year power emerged in the filtered signals (Figure 15) after $0.7 \mathrm{Ma}$ (although less clearly in the SST record) and culminated in a very strong signal by 0.6 to $0.4 \mathrm{Ma}$. The increases in 100,000 -year power are thus basically constrained between 0.9 and $0.4 \mathrm{Ma}$, with the fastest changes between 0.7 and $0.6 \mathrm{Ma}$. The 100,000 -year components of the $\delta^{18} \mathrm{O}$ and $\delta^{13} \mathrm{C}$ signals are in phase to within $5^{\circ}$ (1400 years) during the Brunhes Chron, whereas
SST and $\mathrm{CaCO}_{3}$ lag $\delta^{18} \mathrm{O}$ by $14^{\circ}$ (3900 years) to $34^{\circ}(9400$ years) at the 100,000-year rhythm (Table 8).

Precession. The filtered precessional responses in all five signals increase in amplitude from the Matuyama to the Brunhes Chron, with a very sharp increase between 0.8 and 0.7 $\mathrm{Ma}$ (Figures 16 and 17). The strongest precessional variations occur between 0.75 and $0.675 \mathrm{Ma}$, with oscillations of moderate strength during several intervals in the upper half of the Brunhes Chron. The SST signal also has a very strong 23,000-year signal after $0.2 \mathrm{Ma}$ (Figure 17).

During the strong precessional responses after $0.9 \mathrm{Ma}$, the 


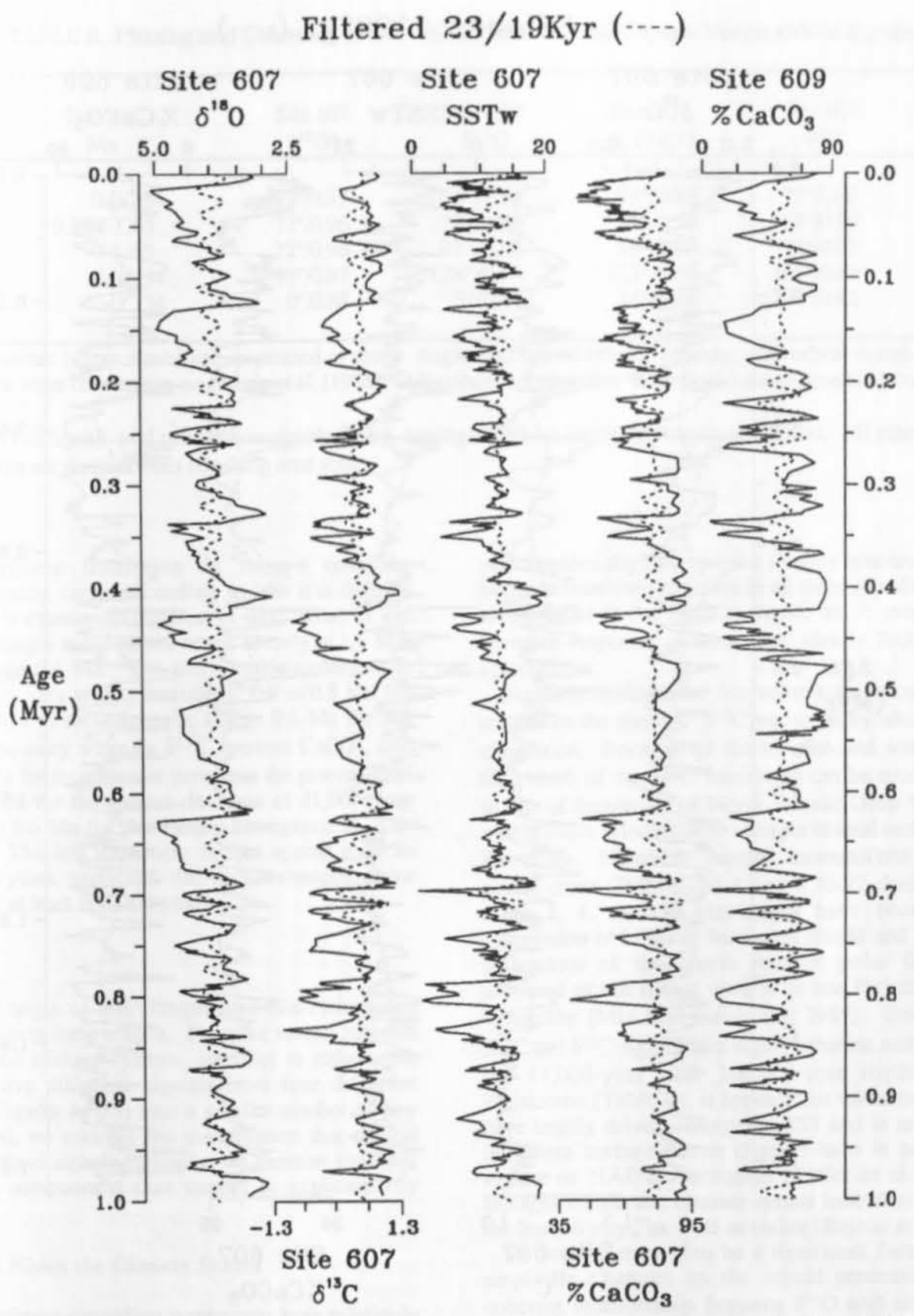

Fig. 17. Overlays of filtered $23,000 / 19,000$-year signals (dashed line) on original records of site $607 \delta^{18} \mathrm{O}, \delta^{13} \mathrm{C}$, SST, and percent $\mathrm{CaCO}_{3}$ and of site 609 percent $\mathrm{CaCO}_{3}$ for the late Pleistocene $(1.0-0 \mathrm{Ma})$.

SST, $\delta^{13} \mathrm{C}$, and $\mathrm{CaCO}_{3}$ signals lag $\delta^{18} \mathrm{O}$ by between $30^{\circ}(2000$ years) and $52^{\circ}$ ( 3300 years), as shown in Table 8. Before 0.9 $\mathrm{Ma}$, there are very few intervals in which these parameters have strong precessional responses in common, and coherences are generally low.

\section{Low-Frequency Responses}

All five signals show substantial concentrations of power at very low frequencies. In Figure 18, we show signals derived from a low-pass filter that extracts power at all periods longer than 120,000 years, which is the low-frequency limit of the 100,000-year filter. This long-wavelength power reflects several different trends in the data, all of which reflect a degree of nonstationarity.

Part of the low-frequency power reflects changes in the mean values of these signals toward more "glacial" conditions (heavier $\delta^{18} \mathrm{O}$, lighter $\delta^{13} \mathrm{C}$, lower $\mathrm{CaCO}_{3}$, and colder SST). Although each record is somewhat different, the major part of this shift appears to be centered on 0.9 to $0.7 \mathrm{Ma}$, close to the level determined by Prell [1982] and Maasch [1988]. This is the most prominent low-frequency shift visible in the $8^{18} \mathrm{O}$ record.

A second kind of low-frequency trend that is prominent in 


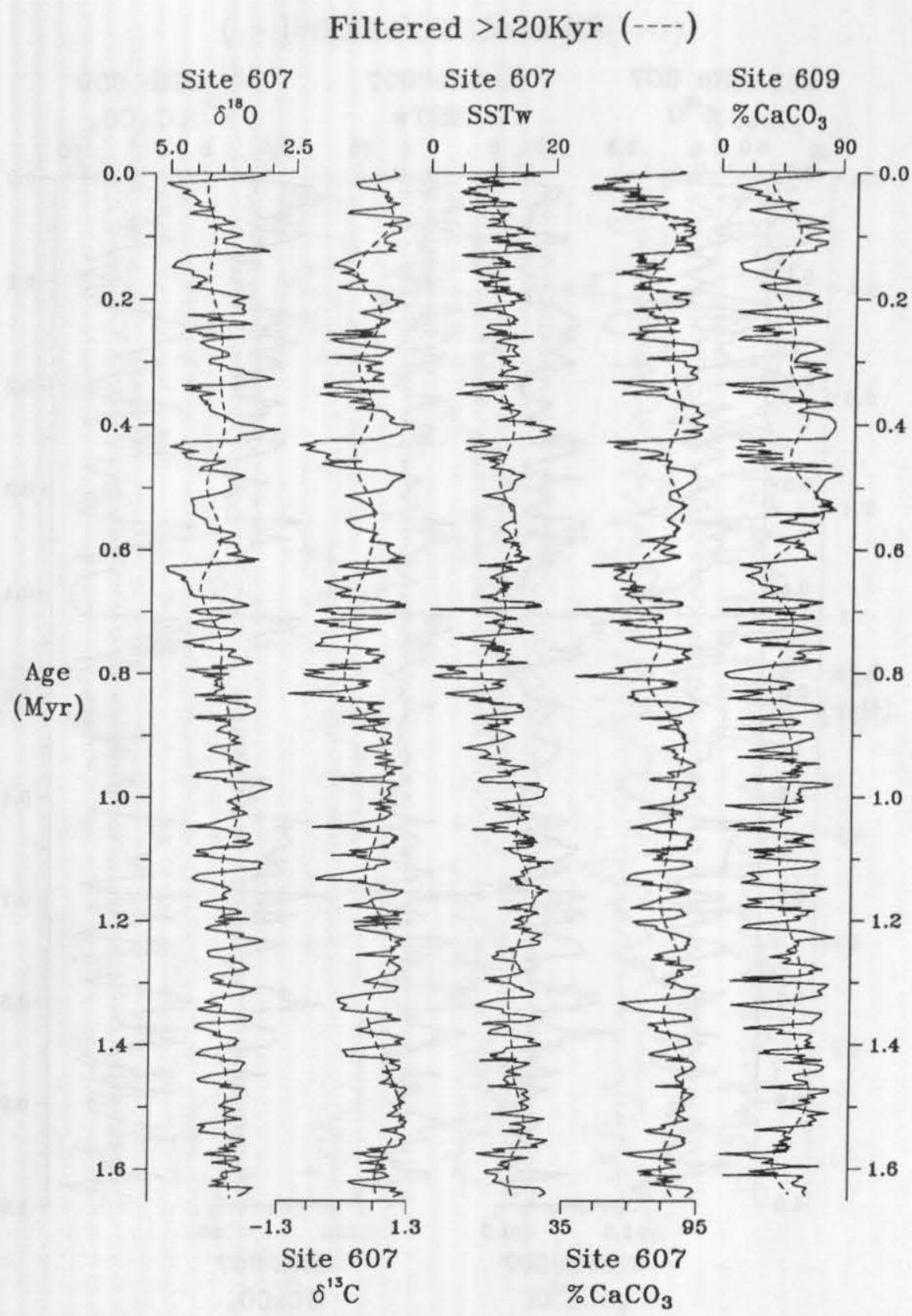

Fig. 18. Overlays of filtered low-frequency $(>120,000$-year) signals (dashed line) on original records (solid line) of site $607 \delta^{18} \mathrm{O}, \delta^{13} \mathrm{C}$, SST, and percent $\mathrm{CaCO}_{3}$ and of site 609 percent $\mathrm{CaCO}_{3}$ for the last $1.65 \mathrm{~m} . \mathrm{y}$. The filter has a central frequency of 0.004 cycles/kyr and bandwidth $0-0.008$ cycles $/ \mathrm{kyr}$.

the $\delta^{13} \mathrm{C}$, percent $\mathrm{CaCO}_{3}$, and SST records at site 607 is a distinctive interval between 0.9 and $0.6 \mathrm{Ma}$ during which unusually high-amplitude variations occur at orbital periods and create the strongest glacial maxima during the entire Pleistocene. This pattern is different from most $\delta^{18} \mathrm{O}$ curves, which register the largest fluctuations and strongest glaciations at and after $0.6 \mathrm{Ma}$, not in the middle Pleistocene.

Some records also show pseudoperiodic behavior at wavelengths of about 200,000 to 500,000 years (Figure 18), and these are not strongly concentrated at the 413,000 -year period of orbital eccentricity (Figure 13). The $\delta^{13} \mathrm{C}$ and percent $\mathrm{CaCO}_{3}$ spectra have variance minima at 413,000 years, while SST and $\delta^{18} \mathrm{O}$ spectra have small maxima (Figure 13),

Finally, the low-frequency oscillation toward warm SST values near 1.25-1.1 Ma is an artifact of the absence of the species $N$. pachyderma (sinistral-coiling), the polar endmember foraminifer [Ruddiman et al., 1986a, c]. It is unclear whether this reflects climatic change or evolutionary effects. 
TABLE 8. Phasing and Coherence of Site 607 and 609 Climatic Signals Versus Orbital Signals

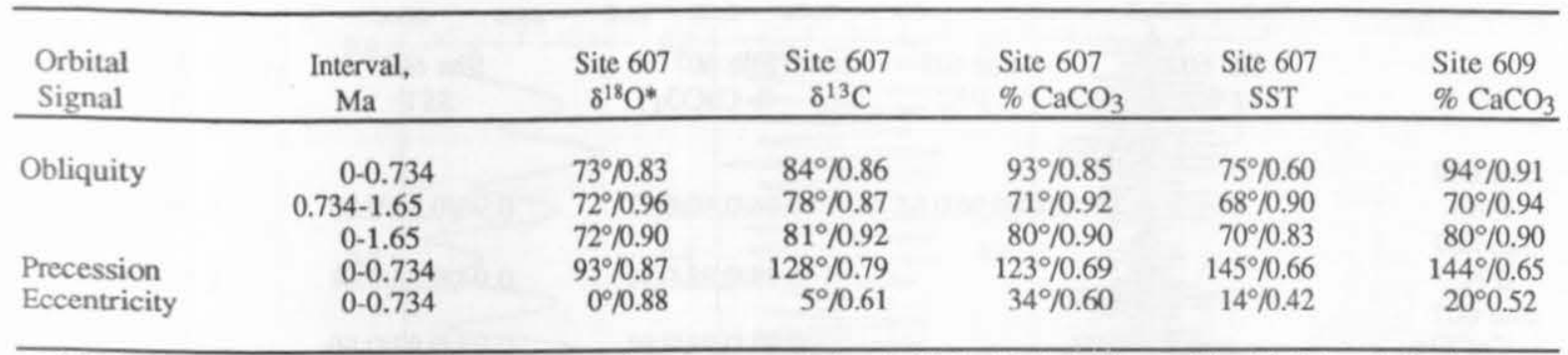

All phases (number before slash) are expressed as phase angle lags behind orbital forcing, with orbital signal phasing defined using the same convention as Imbrie et al. [1984]. All coherences (number after slash) are expressed as coherency squared.

${ }^{*}$ Phase of $\delta^{18} \mathrm{O}$ obliquity and precession signals set by tuning to orbital forcing as explained in text. All other phases and all coherences are derived from resulting time scale.

The mid-Pleistocene transition is thus a complex phenomenon; its timing varies according to how it is defined and which record is examined (Figures 14-18). Some of the mid-Pleistocene changes noted above occur as early as $1.1 \mathrm{Ma}$, and others as late as $0.4 \mathrm{Ma}$. The most striking changes in different parameters vary widely in timing: 0.9 to $0.8 \mathrm{Ma}$ for changes in the mean of most signals; 0.9 to $0.6 \mathrm{Ma}$ for the distinctive low-frequency wave in $8^{13} \mathrm{C}$, percent $\mathrm{CaCO}_{3}$, and SST; 0.8 to $0.7 \mathrm{Ma}$ for increases in power in the precessional band; 0.8 to $0.6 \mathrm{Ma}$ for the fastest decrease of 41,000 -year power; and 0.7 to $0.6 \mathrm{Ma}$ for the fastest emergence of 100 000 -year power. The full transition is thus spread over as much as 700,000 years, and even the fastest changes occur over an interval of at least 200,000 years.

\section{DISCUSSION}

We explore the origin of this complicated mid-Pleistocene evolution of climate in three stages. First, we review internal linkages within the climate system, in order to reduce the complexities in five different signals from four different climate proxies (Figures 14-18) into a smaller number of key variables. Second, we address the contribution that orbital forcing makes to these signals. Finally, we examine the lowfrequency signal components that cannot be explained by orbital forcing.

\section{Internal Linkages Within the Climate System}

Several of the climate-recording parameters have relatively clear linkages within the climate system. Changes in northern hemisphere (particularly North American) ice volume dominate the $\delta^{18} \mathrm{O}$ trends, and general circulation modeling experiments show that ice in North America affects North Atlantic SST and sea ice extent by altering surface winds over the ocean [Manabe and Broccoli, 1985; Broccoli and Manabe, 1987]. These ice sheet effects on the North Atlantic also impact the productivity of foraminifera and coccoliths in surface waters and thus the $\mathrm{CaCO}_{3}$ content of the sediments, as does continental sediment rafted from the ice sheets to the ocean via icebergs [Ruddiman, 1977]. These proposed ice sheet/ocean linkages are all consistent with data summarized in Tables 8 and 9: the highly coherent, in-phase behavior of $8^{18} \mathrm{O}$, SST, and percent $\mathrm{CaCO}_{3}$ at the dominant 41,000-year Matuyama rhythm; the highly coherent, nearly in-phase responses at the dominant 100,000 - year Brunhes rhythm; and the roughly synchronous transitions between these two regimes in all three signals. Dissolution is also a factor in the $\mathrm{CaCO}_{3}$ signal, but it may involve more complex response pattcrns less clearly linked to ice sheet forcing.

Northern hemisphere ice volume also exerts a significant control on the site $607 \delta^{13} \mathrm{C}$ variations by altering deep-ocean circulation. Because of the location and water depth of site 607 , much of the $8^{13} \mathrm{C}$ variability can be ascribed to changes in rate of formation of North Atlantic Deep Water (NADW), with a lesser effect due to changes in total carbon inventory in the ocean. Negative benthic foraminiferal $\delta^{13} \mathrm{C}$ values in piston cores CHN82-24-4 and V30-97 during the isotopic stage 2, 4, and 6 glaciations have been attributed to suppression of NADW formation [Boyle and Keigwin, 1985]. Migrations of the North Atlantic polar front have been proposed as the major control on late Pleistocene deepwater variability [Mix and Fairbanks, 1985]. Because the $\delta^{18} \mathrm{O}$, SST, and $8^{13} \mathrm{C}$ signals are highly coherent and in phase at both the 41,000-year and 100,000-year rhythms during the Pleistocene (Table 9), it appears that variations in ice volume have largely driven changes in SST and in sea ice extent and that these surface-ocean changes have in turn had a major impact on NADW formation [Keffer et al., 1988]. These linkages within the climate system have thus been strong for the last $1.6 \mathrm{~m} . y$., as well as earlier [Raymo et al., this issue].

Ice volume may also be a significant factor in the loweramplitude changes in the orbital precession band. The coherent relationship between $\delta^{18} \mathrm{O}$ and orbital precession during the Brunhes Chron indicates that ice volume is an important component of the precessional frequencies in the $\delta^{18} \mathrm{O}$ signal [Imbrie et al., 1984], and we have shown similar, but weaker, trends during the upper portion of the Matuyama (Figure 7).

The precessional band connections between the ice sheets and the ocean are not, however, as clear as those for obliquity and eccentricity. The 3000-year lag of SST (minima) behind $\delta^{18} \mathrm{O}$ (maxima) suggests that other factors override the immediate response of the surface ocean to ice volume, and both $\delta^{13} \mathrm{C}$ (minima) and $\mathrm{CaCO}_{3}$ (minima) also show substantial lags behind $\delta^{18} \mathrm{O}$ (Table 8 ). One possibility is meltwater from the ice sheets, which would have a particularly strong precessional signal that would lag ice volume by a maximum of $1 / 4$ wavelength or 5000 to 6000 years 
TABLE 9. Coherences Among Site 607 and Site 609 Climatic Signals

\begin{tabular}{|c|c|c|c|c|c|}
\hline$\sqrt{2}+2$ & $\begin{array}{c}\text { Site } 607 \\
\delta^{18} \mathrm{O} \\
\end{array}$ & $\begin{array}{c}\text { Site } 607 \\
8^{13} \mathrm{C} \\
\end{array}$ & $\begin{array}{l}\text { Site } 607 \\
\% \mathrm{CaCO}_{3} \\
\end{array}$ & $\begin{array}{c}\text { Site } 607 \\
\text { SST } \\
\end{array}$ & $\begin{array}{l}\text { Site } 609 \\
\% \mathrm{CaCO}_{3} \\
\end{array}$ \\
\hline $\begin{array}{c}\text { Site } 607 \\
8^{18} \mathrm{O}\end{array}$ & & $0.99 / 0.90 / 0.84$ & $0.96 / 0.90 / 0.77$ & $0.96 / 0.86 / 0.80$ & $0.95 / 0.81 / 0.73$ \\
\hline $\begin{array}{l}\text { Site } 607 \\
\delta^{13} \mathrm{C}\end{array}$ & & & $0.98 / 0.88 / 0.91$ & $0.94 / 0.86 / 0.64$ & $0.97 / 0.85 / 0.92$ \\
\hline $\begin{array}{l}\text { Site } 607 \\
\mathrm{CaCO}_{3}\end{array}$ & & & $0.94 / 0.94 / 0.59$ & $0.98 / 0.97 / 0.90$ & \\
\hline $\begin{array}{l}\text { Site } 607 \\
\text { SST } \\
\text { Site } 609 \\
\% \mathrm{CaCO}_{3}\end{array}$ & & & & & $0.91 / 0.95 / 0.64$ \\
\hline
\end{tabular}

[Ruddiman and McIntyre, 1981]. Another possibility is that low-latitude insolation (monsoonal) forcing in part controls this SST response, perhaps in combination with the ice sheets. This might occur via (1) a spin-up of the North Atlantic subtropical gyre due to increased anticyclonic subsidence of air over the oceans as mass compensation for increased upward monsoonal motion over land [Kutzback and Guetter, 1984] and (2) effects of monsoon-modulated Mediterranean outflow on North Atlantic salinity and, perhaps, SST [Rossignol-Strick, 1983].

We conclude that much of the climatic information at the orbital periodicities in the five Pleistocene records can be ascribed directly to insolation-driven changes in ice sheets, especially in North America, and their subsequent impact on the adjacent ocean. Other responses, including the change in dominance of orbital rhythms and the low-frequency responses in $\delta^{13} \mathrm{C}$, percent $\mathrm{CaCO}_{3}$, and SST, cannot be explained by this kind of linkage.

\section{Role of Orbital Forcing}

Because obliquity provides the strongest orbital forcing at high latitudes [Milankovitch, 1941; Berger, 1978], it is the rhythm most likely to control high-latitude ice sheets, assuming that other forcing exists to initiate glaciation [Ruddiman and Raymo, 1988]. Thus, perhaps the least surprising result of this study is the dominance of a 41,000 year response in the Matuyama Chron, as well as the coherent 41,000 -year responses in other climatic indicators $\left(8^{13} \mathrm{C}\right.$, percent $\mathrm{CaCO}_{3}$, and SST) that are heavily impacted by ice sheet changes.

The long-term trend of orbital obliquity (Figure 19) shows relatively high-amplitude fluctuations early in the Pleistocene, followed by a slow decline to low-amplitude variations between about 0.9 and $0.65 \mathrm{Ma}$, and then some reemergence of power in the late Pleistocene. Because this trend is similar to the mid-Pleistocene decrease in 41,000-year power in the $\delta^{18} \mathrm{O}$ (and other) signals (Figure 14), some of the mid-Pleistocene shift in orbital dominance may be related to a linear response of the climate system to the weaker obliquity forcing.

Other factors, however, suggest that the climate system lost sensitivity to obliquity forcing during the middle and late Pleistocene. The amplitude minima in all five climatic records (Figure 14) occur somewhat later than the orbital forcing, around 0.6 to $0.5 \mathrm{Ma}$, although this may be partly an artifact of the slow sedimentation rates in that part of both the site 607 and 609 records (Figure 10). More diagnostically, no record shows a return of the 41,000 -year variations to the amplitudes attained during the Matuyama, whereas the orbital forcing does regain full amplitude (Figure 19). The system thus appears to have become less sensitive to obliquity forcing during the mid-Pleistocene and Brunhes.

The development of the 100,000 -year signal is more enigmatic. Imbrie et al. [1984] found that tuning to orbital obliquity and precession yielded a 100,000 -year $\delta^{18} \mathrm{O}$ signal that was both coherent and in phase with eccentricity forcing, suggesting a linear response of the climate system to orbital eccentricity. Direct insolation forcing at this period is, however, too weak to explain the dominant Brunhes response; this suggests internal amplification of this signal within the climate system.

The kind of internal amplification remains unclear. Hypotheses that rely on nonlinear responses to precession, such as faster ablation than accumulation [e.g., Imbrie and Imbrie, 1980], also predict a strong response at the $413,000-$ year eccentricity period. Although it is difficult to test for 413,000 -year power in the relatively brief interval during which the 100,000 -year signal has been strong, there is no clear indication of such a trend in the low-frequency filter (Figure 18). This argues against this class of hypotheses.

This points toward hypotheses involving resonant interactions within the climate system, such as ice/bedrock interactions [e.g., Peltier, 1982] or interactions between the ice sheets and the deep ocean, which may involve changes in $\mathrm{CO}_{2}$ levels [e.g., Saltzman, 1987]. It is unlikely that either of these alternatives can, by itself, explain the change from a 41,000 -year to a 100,000 -year regime during the midPleistocene. Some additional change (probably tectonic) needs to be imposed to trigger different behavior in the key components of the climate system.

The mid-Pleistocene increase in precessional response of the $8^{18} \mathrm{O}$ and other signals (Figures 16 and 17) is not explained by long-term trends in orbital forcing (Figure 19). It may be 


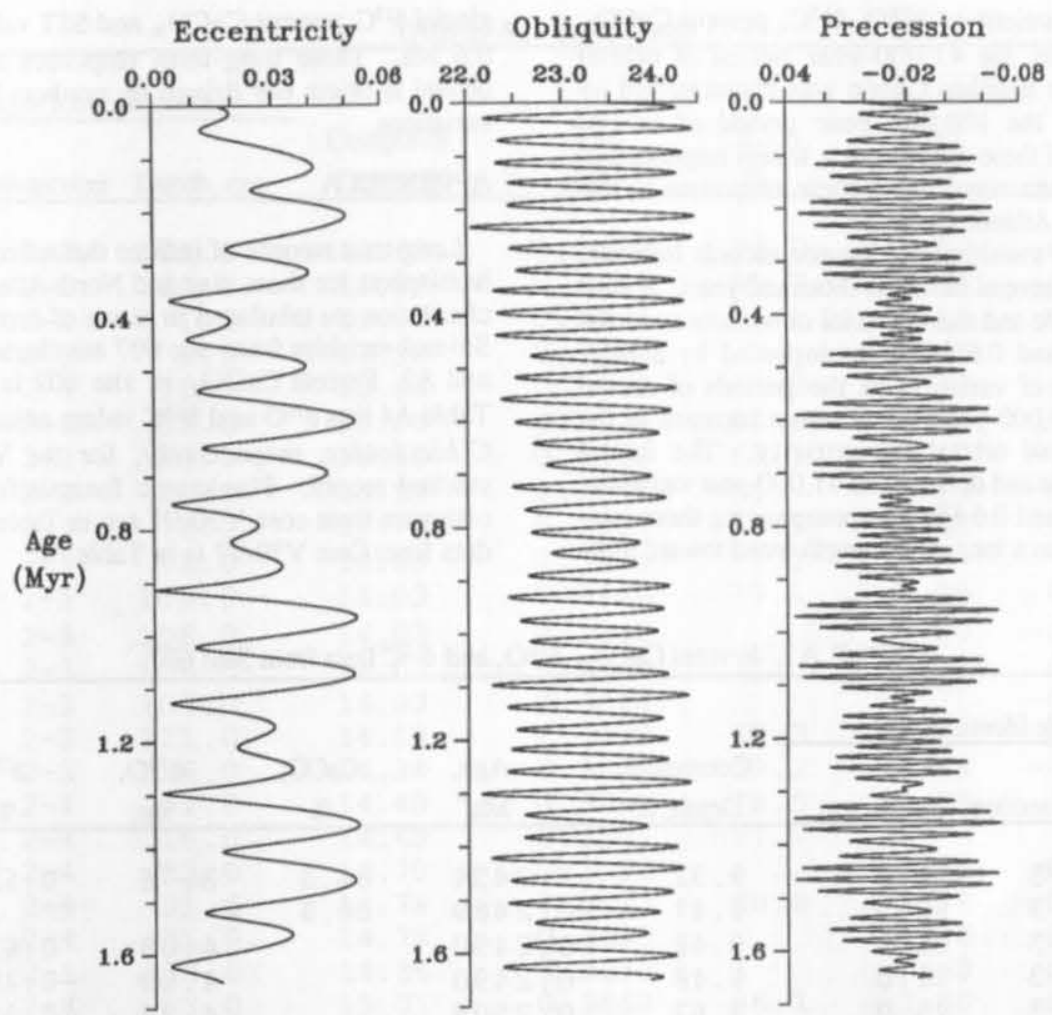

Fig. 19. Orbital eccentricity, obliquity, and precession (using the precessional index, e sin w) over the last 1.65 m.y. [from Berger, 1978].

linked to the onset of larger ice sheets, whose southern limits in North America and Europe must have extended farther into middle latitudes, and thus come under the influence of stronger precessional forcing [Ruddiman and McIntyre, 1981]. Or it might in some way reflect an increased sensitivity of ice sheets to precessional insolation heating of low- and mid-latitude land masses at latitudes south of the ice sheets [Kutzbach, 1981].

\section{Non-orbital Climatic Change}

Finally, there are components of these signals that are not explained by coherent responses to orbital forcing. We focus on the low-frequency components (Figure 18), but this category also includes that portion of signals concentrated at orbital periods but not coherent with the forcing. To some extent, these two categories are interrelated; for example, most of the low-frequency $8^{13} \mathrm{C}$ and $\mathrm{CaCO}_{3}$ signals during the Matuyama (Figure 18) appear to be due to changes in the amplitude of the glacial extremes of the 41,000-year oscillations. Thus, while the individual oscillations occur at orbital periods, part of the modulation of these oscillations is not explained by a linear model of orbital forcing.

To some extent, these signals may reflect imperfections in the climate monitors, raising the question of what portion of the signals is real. As noted earlier, the absence of the coldwater foraminifer $N$. pachyderma (sinistral) gives the SST curve a suspect warming trend between 1.25 and $1.1 \mathrm{Ma}$. For the $\delta^{18} \mathrm{O}$ and $\delta^{13} \mathrm{C}$ curves, the amplitude of a given glacial or interglacial oscillation depends critically on the presence of the analyzed species in abundances sufficient to avoid bioturbational dilution by individuals from adjoining levels.

The $\mathrm{CaCO}_{3}$ curve, however, is less subject to such problems, and it is also in many ways very similar in appearance to the $\delta^{13} \mathrm{C}$ curve (Figure 18). The fact that two such different monitors of the climate system experienced very similar changes supports the contention that this lowfrequency signal is real, as does the more modest similarity to the SST signal, especially during the prominent shift toward more glacial values in the mid-Pleistocene $(0.9-0.6 \mathrm{Ma})$.

As noted previously, the near absence of 413,000 -year eccentricity power in these signals suggests that they are not orbital in origin. Because the site $607 \delta^{18} \mathrm{O}$ curve (like other $\delta^{18} \mathrm{O}$ curves) shows little or no glacial long-wavelength anomaly in the mid-Pleistocene, the low-frequency $8^{13} \mathrm{C}$, $\mathrm{CaCO}_{3}$ and SST responses are probably not the result of ice sheet forcing. For this to be true, an anomalously large volume of ice in North America (needed to force the various North Atlantic responses) would have to be coincidentally offset by anomalously small volumes of ice elsewhere in the world, so that the $\delta^{18} \mathrm{O}$ curve showed no long-wavelength anomaly between 0.9 and $0.6 \mathrm{Ma}$. This is unlikely.

The origin of these long-wavelength anomalies within certain parts of the climate system during the middle Pleistocene is uncertain. The fact that the most anomalous long-wavelength features in all three signals occur between 0.9 and $0.6 \mathrm{Ma}$ during the mid-Pleistocene transition suggests that they may be in some way linked to the forcing that produced the transition in orbital power.

\section{SUMMARY}

The climatic response of the high latitudes of the northern hemisphere during the Matuyama Chron was characterized by 
coherent, in-phase variations of $\delta^{18} \mathrm{O}, \delta^{13} \mathrm{C}$, percent $\mathrm{CaCO}_{3}$, and SST dominated by the 41,000-year period of orbital obliquity. Most of the Brunhes Chron was characterized by similar variations at the 100,000 -year period of orbital eccentricity. In each of these regimes, ice sheets responded to orbital forcing and then transferred their responses to the surface and deep North Atlantic Ocean.

The mid-Pleistocene transition in climatic records from site 607 was spread across several hundred thousand years. A shift toward higher-amplitude and more glacial conditions occurred mainly between 0.9 and $0.6 \mathrm{Ma}$, accompanied by a large increase in amplitude of variation at the periods of orbital precession (23,000/19,000 years) and some increase at the 100,000 -year period of orbital eccentricity. The fastest increase in 100,000-year and decrease in 41,000-year variability occurred between 0.7 and $0.6 \mathrm{Ma}$. Accompanying these midPleistocene changes was a long-wavelength trend toward more glacial $\delta^{13} \mathrm{C}$, percent $\mathrm{CaCO}_{3}$ and $\mathrm{SST}$ values between 0.9 and $0.6 \mathrm{Ma}$. These long-term responses appear to be neither orbital in origin nor driven by northern hemisphere ice sheet variations.

\section{APPENDIX A}

Long-term records of indices that reflect changes in northem hemisphere ice sheet size and North Atlantic surface and deep circulation are tabulated in terms of depth and estimated age. Several variables from site 607 are characterized in Tables Al and $\mathrm{A} 2$. Percent $\mathrm{CaCO}_{3}$ in site 609 is listed in Table A3. Table A4 lists $\delta^{18} \mathrm{O}$ and $\delta^{13} \mathrm{C}$ values adjusted to Uvigerina and Cibicidoides, respectively, for the V30-97/CHN82-24-4 stacked record. Planktonic foraminiferal counts and SST estimates from core V30-97 are in Table A5. Percent $\mathrm{CaCO}_{3}$ data from Core V30-97 is in Table A6.

TABLE Al. Percent $\mathrm{CaCO}_{3}, \delta^{18} \mathrm{O}$, and $\delta^{13} \mathrm{C}$ Data from Site 607

\begin{tabular}{|c|c|c|c|c|c|c|c|c|}
\hline Hole & Core-section & n Depth, $\mathrm{cm}$ & $\begin{array}{c}\text { Composite } \\
\text { Depth, m }\end{array}$ & $\begin{array}{l}\text { Age, } \\
\mathrm{Ma}^{*}\end{array}$ & $\begin{array}{c}\mathrm{CaCO}_{3}, \\
\%\end{array}$ & $\begin{array}{l}8^{18} \mathrm{O}, \\
\% 0\end{array}$ & $\begin{array}{c}\delta^{13} \mathrm{C}, \\
\% 0\end{array}$ & $\begin{array}{c}\text { Species } \\
\text { Code }\end{array}$ \\
\hline $\begin{array}{l}607 \mathrm{~A} \\
607 \mathrm{~A}\end{array}$ & $\begin{array}{l}2-3 \\
2-3\end{array}$ & $\begin{array}{l}45.5 \\
60.5\end{array}$ & $\begin{array}{l}9.32 \\
9.47\end{array}$ & $\begin{array}{l}0.2454 \\
0.2489\end{array}$ & $\begin{array}{l}66.3 \\
66.9\end{array}$ & 3.76 & 0.62 & C \\
\hline $607 \mathrm{~A}$ & $2-3$ & 61.0 & 9.48 & 0.2490 & & 4.08 & 0.63 & C \\
\hline $607 A$ & $2-3$ & 61.0 & 9.48 & 0.2490 & & 4.69 & -0.75 & U \\
\hline $607 \mathrm{~A}$ & $2-3$ & 75.0 & 9.62 & 0.2508 & & 4.70 & -0.93 & $\mathrm{U}$ \\
\hline $607 A$ & $2-3$ & 75.5 & 9.63 & 0.2509 & 66.5 & & & \\
\hline $607 \mathrm{~A}$ & $2-3$ & 90.5 & 9.77 & 0.2520 & 83.7 & & & \\
\hline $607 \mathrm{~A}$ & $2-3$ & 91.0 & 9.78 & 0.2520 & & 4.10 & 0.81 & C \\
\hline $607 A$ & $2-3$ & 91.0 & 9.78 & 0.2520 & & 4.53 & -0.70 & $\mathrm{U}$ \\
\hline $607 \mathrm{~A}$ & $2-3$ & 105.0 & 9.92 & 0.2530 & & 4.44 & -0.62 & $\mathrm{U}$ \\
\hline $607 A$ & $2-3$ & 105.5 & 9.93 & 0.2530 & 71.0 & & & \\
\hline $607 \mathrm{~A}$ & $2-3$ & 120.5 & 10.07 & 0.2541 & 69.9 & & & \\
\hline $607 \mathrm{~A}$ & $2-3$ & 121.0 & 10.08 & 0.2541 & & 3.69 & 0.64 & C \\
\hline $607 A$ & $2-3$ & 121.0 & 10.08 & 0.2541 & & 4.43 & -0.53 & $\mathrm{U}$ \\
\hline $607 \mathrm{~A}$ & $2-3$ & 135.5 & 10.22 & 0.2551 & 69.4 & 3.94 & 0.65 & C \\
\hline $607 \mathrm{~A}$ & $2-3$ & 135.0 & 10.22 & 0.2551 & & 4.37 & -0.61 & $\mathrm{U}$ \\
\hline $607 \mathrm{~A}$ & $2-4$ & 0.5 & 10.38 & 0.2564 & 61.5 & 4.21 & -0.92 & $\mathrm{U}$ \\
\hline $607 \mathrm{~A}$ & $2-4$ & 1.0 & 10.38 & 0.2564 & & 3.39 & -0.75 & C \\
\hline 607 & $2-1$ & 55.0 & 10.52 & 0.2585 & 68.6 & 3.94 & 0.71 & C \\
\hline 607 & $2-1$ & 55.0 & 10.52 & 0.2585 & & 3.83 & 0.19 & C \\
\hline 607 & $2-1$ & 55.0 & 10.52 & 0.2585 & & 3.48 & 0.08 & C \\
\hline 607 & $2-1$ & 61.0 & 10.59 & 0.2595 & & 2.91 & 0.74 & C \\
\hline 607 & $2-1$ & 78.0 & 10.76 & 0.2637 & 64.7 & 3.50 & -0.30 & C \\
\hline 607 & $2-1$ & 91.0 & 10.89 & 0.2684 & & 3.79 & -0.15 & C \\
\hline 607 & $2-1$ & 106.0 & 11.03 & 0.2745 & 90.8 & 3.65 & 0.44 & C \\
\hline 607 & $2-1$ & 121.0 & 11.18 & 0.2805 & & 3.39 & 0.91 & C \\
\hline 607 & $2-1$ & 136.0 & 11.34 & 0.2861 & 91.2 & 3.22 & 0.77 & C \\
\hline 607 & $2-2$ & 1.0 & 11.48 & 0.2898 & 90.1 & 3.28 & 0.62 & C \\
\hline 607 & $2-2$ & 1.0 & 11.48 & 0.2898 & & 3.13 & 0.73 & C \\
\hline 607 & $2-2$ & 16.0 & 11.63 & 0.2925 & 79.4 & 3.36 & -0.32 & C \\
\hline 607 & $2-2$ & 16.0 & 11.63 & 0.2925 & & 3.34 & -0.33 & C \\
\hline 607 & $2-2$ & 31.0 & 11.78 & 0.2951 & 69.7 & 4.29 & -0.75 & $\mathrm{U}$ \\
\hline 607 & $2-2$ & 31.0 & 11.78 & 0.2951 & & 4.14 & -0.79 & $\mathrm{U}$ \\
\hline 607 & $2-2$ & 53.0 & 12.01 & 0.2998 & 86.2 & 3.46 & 0.53 & C \\
\hline 607 & $2-2$ & 53.0 & 12.01 & 0.2998 & & 3.76 & 0.55 & C \\
\hline 607 & $2-2$ & 61.0 & 12.09 & 0.3019 & 86.3 & 3.55 & 0.69 & C \\
\hline 607 & $2-2$ & 78.0 & 12.26 & 0.3064 & 86.2 & 3.26 & 0.36 & C \\
\hline 607 & $2-2$ & 91.0 & 12.38 & 0.3096 & 91.3 & 3.24 & 0.49 & C \\
\hline 607 & $2-2$ & 106.0 & 12.53 & 0.3139 & 89.4 & 2.93 & 0.39 & C \\
\hline
\end{tabular}


TABLE A1. (continued)

\begin{tabular}{|c|c|c|c|c|c|c|c|c|}
\hline \multicolumn{3}{|c|}{ DSDP Sample Identification } & \multirow[b]{2}{*}{$\begin{array}{l}\text { Composite } \\
\text { Depth, m }\end{array}$} & \multirow[b]{2}{*}{$\begin{array}{l}\text { Age, } \\
\mathrm{Ma}^{*}\end{array}$} & \multirow[b]{2}{*}{$\begin{array}{c}\mathrm{CaCO}_{3}, \\
\%\end{array}$} & \multirow[b]{2}{*}{$\begin{array}{c}\delta^{18} \mathrm{O} \\
\% 0\end{array}$} & \multirow[b]{2}{*}{$\begin{array}{l}8^{13} \mathrm{C}, \\
\% 0\end{array}$} & \multirow[b]{2}{*}{$\begin{array}{c}\text { Species } \\
\text { Code }\end{array}$} \\
\hline Hole & Core-section & Depth, cm & & & & & & \\
\hline 607 & $2-2$ & 121.0 & 12.68 & 0.3187 & 88.2 & 2.87 & 0.72 & C \\
\hline 607 & $2-2$ & 136.0 & 12.84 & 0.3235 & 91.2 & 2.45 & 0.56 & C \\
\hline 607 & $2-3$ & 1.0 & 12.98 & 0.3276 & 91.1 & 2.13 & 0.35 & C \\
\hline 607 & $2-3$ & 1.0 & 12.98 & 0.3276 & & 2.46 & 0.68 & C \\
\hline 607 & $2-3$ & 16.0 & 13.13 & 0.3301 & 88.3 & 2.60 & 0.71 & $\mathrm{C}$ \\
\hline 607 & $2-3$ & 31.0 & 13.28 & 0.3324 & 54.6 & 2.89 & -0.12 & $\mathrm{C}$ \\
\hline 607 & $2-3$ & 53.0 & 13.51 & 0.3360 & 63.1 & 3.17 & -0.43 & $\mathrm{C}$ \\
\hline 607 & $2-3$ & 61.0 & 13.59 & 0.3374 & 66.7 & 4.13 & -0.27 & C \\
\hline 607 & $2-3$ & 78.0 & 13.76 & 0.3397 & 70.6 & 3.88 & -0.43 & C \\
\hline 607 & $2-3$ & 91.0 & 13.88 & 0.3414 & 77.1 & & & \\
\hline 607 & $2-3$ & 106.0 & 14.03 & 0.3440 & 79.1 & 4.08 & 0.08 & C \\
\hline 607 & $2-3$ & 106.0 & 14.03 & 0.3440 & & 4.00 & -0.07 & C \\
\hline 607 & $2-3$ & 106.0 & 14.03 & 0.3440 & & 4.12 & 0.09 & C \\
\hline 607 & $2-3$ & 106.0 & 14.03 & 0.3440 & & 4.71 & -0.44 & $\mathrm{U}$ \\
\hline 607 & $2-3$ & 121.0 & 14.18 & 0.3472 & 68.3 & 3.73 & 0.83 & C \\
\hline 607 & $2-3$ & 136.0 & 14.34 & 0.3506 & 59.2 & 3.48 & -0.49 & C \\
\hline 607 & $2-4$ & 1.0 & 14.48 & 0.3541 & 78.5 & 3.80 & -0.28 & C \\
\hline 607 & $2-4$ & 16.0 & 14.63 & 0.3577 & 77.7 & & & \\
\hline 607 & $2-4$ & 23.0 & 14.70 & 0.3593 & & 4.39 & -0.42 & $\mathrm{U}$ \\
\hline 607 & $2-4$ & 31.0 & 14.78 & 0.3613 & 80.8 & 3.88 & 0.09 & C \\
\hline 607 & $2-4$ & 31.0 & 14.78 & 0.3613 & & 4.26 & -0.59 & $\mathrm{U}$ \\
\hline 607 & $2-4$ & 39.0 & 14.86 & 0.3633 & & 3.63 & 0.06 & C \\
\hline 607 & $2-4$ & 53.0 & 15.01 & 0.3668 & 86.1 & 3.80 & 0.20 & C \\
\hline 607 & $2-4$ & 53.0 & 15.01 & 0.3668 & & 4.24 & -0.28 & $\mathrm{U}$ \\
\hline 607 & $2-4$ & 61.0 & 15.09 & 0.3688 & 85.7 & 3.58 & 0.54 & C \\
\hline 607 & $2-4$ & 78.0 & 15.26 & 0.3734 & 91.9 & 3.59 & 0.24 & C \\
\hline 607 & $2-4$ & 78.0 & 15.26 & 0.3734 & & 4.27 & -0.77 & $\mathrm{U}$ \\
\hline 607 & $2-4$ & 91.0 & 15.38 & 0.3787 & 91.1 & 4.07 & -0.21 & $\mathrm{U}$ \\
\hline 607 & $2-4$ & 91.0 & 15.38 & 0.3787 & & 3.68 & 0.82 & C \\
\hline 607 & $2-4$ & 106.0 & 15.53 & 0.3855 & 94.5 & 3.96 & -0.07 & $\mathrm{U}$ \\
\hline 607 & $2-4$ & 121.0 & 15.68 & 0.3892 & 92.3 & 3.88 & 0.02 & $\mathrm{U}$ \\
\hline 607 & $2-4$ & 136.0 & 15.84 & 0.3927 & 88.5 & 3.14 & 0.84 & C \\
\hline 607 & $2-5$ & 1.0 & 15.98 & 0.3960 & 91.0 & 3.77 & -0.06 & $\mathrm{U}$ \\
\hline 607 & $2-5$ & 1.0 & 15.98 & 0.3960 & & 3.08 & 0.85 & C \\
\hline 607 & $2-5$ & 16.0 & 16.14 & 0.3993 & 91.4 & 3.04 & 0.85 & C \\
\hline 607 & $2-5$ & 16.0 & 16.14 & 0.3993 & & 2.81 & 1.08 & C \\
\hline 607 & $2-5$ & 23.0 & 16.20 & 0.4007 & & 2.82 & 1.22 & C \\
\hline 607 & $2-5$ & 23.0 & 16.20 & 0.4007 & & 2.72 & 1.24 & C \\
\hline 607 & $2-5$ & 31.0 & 16.28 & 0.4022 & 96.4 & 2.65 & 1.30 & C \\
\hline 607 & $2-5$ & 53.0 & 16.50 & 0.4061 & 93.7 & 2.40 & 1.29 & C \\
\hline 607 & $2-5$ & 61.0 & 16.58 & 0.4076 & 93.7 & 2.17 & 1.06 & C \\
\hline 607 & $2-5$ & 78.0 & 16.75 & 0.4111 & 85.0 & 2.54 & 1.05 & C \\
\hline 607 & $2-5$ & 91.0 & 16.89 & 0.4138 & 93.5 & 2.69 & 1.01 & C \\
\hline 607 & $2-5$ & 106.0 & 17.03 & 0.4167 & 93.5 & 3.03 & 0.93 & C \\
\hline 607 & $2-5$ & 121.0 & 17.18 & 0.4204 & 90.3 & 3.00 & 0.73 & C \\
\hline 607 & $2-5$ & 136.0 & 17.33 & 0.4237 & 80.4 & 2.99 & 0.56 & C \\
\hline 607 & $2-5$ & 143.0 & 17.40 & 0.4252 & & 3.17 & -0.61 & C \\
\hline 607 & $2-6$ & 1.0 & 17.48 & 0.4270 & 52.7 & 4.13 & -0.56 & C \\
\hline 607 & $2-6$ & 7.5 & 17.55 & 0.4284 & 55.8 & & & \\
\hline 607 & $2-6$ & 16.0 & 17.64 & 0.4303 & 65.8 & 4.10 & -0.76 & C \\
\hline 607 & $2-6$ & 23.0 & 17.70 & 0.4319 & & 4.18 & -0.92 & C \\
\hline 607 & $2-6$ & 31.0 & 17.78 & 0.4342 & 55.6 & 4.96 & -1.49 & $\mathrm{U}$ \\
\hline 607 & $2-6$ & 53.0 & 18.00 & 0.4380 & 58.3 & & & \\
\hline 607 & $2-6$ & 61.0 & 18.08 & 0.4394 & 67.5 & 4.06 & -0.77 & C \\
\hline 607 & $2-6$ & 78.0 & 18.25 & 0.4422 & 74.6 & 3.81 & -0.58 & C \\
\hline 607 & $2-6$ & 91.0 & 18.39 & 0.4447 & 76.8 & 4.12 & -0.42 & C \\
\hline 607 & $2-6$ & 106.0 & 18.53 & 0.4476 & 77.4 & 4.04 & -0.28 & C \\
\hline
\end{tabular}


TABLE A1. (continued)

\begin{tabular}{|c|c|c|c|c|c|c|c|c|}
\hline Hole & Core-section & Depth, cm & $\begin{array}{c}\text { Composite } \\
\text { Depth, m }\end{array}$ & $\begin{array}{l}\text { Age, } \\
\mathrm{Ma}^{*}\end{array}$ & $\begin{array}{c}\mathrm{CaCO}_{3}, \\
\%\end{array}$ & $\begin{array}{l}8^{18} \mathrm{O} \\
\% 0\end{array}$ & $\begin{array}{c}\delta^{13} \mathrm{C}, \\
\%\end{array}$ & $\begin{array}{c}\text { Species } \\
\text { Codet }\end{array}$ \\
\hline 607 & $2-6$ & 121.0 & 18.68 & 0.4505 & 71.6 & 4.05 & -0.38 & C \\
\hline 607 & $\begin{array}{l}2-6 \\
2-7\end{array}$ & $\begin{array}{r}136.0 \\
1.0\end{array}$ & $\begin{array}{l}18.83 \\
18.98\end{array}$ & $\begin{array}{l}0.4526 \\
0.4546\end{array}$ & $\begin{array}{l}67.2 \\
75.9\end{array}$ & 3.99 & -0.36 & C \\
\hline $\begin{array}{l}607 \\
607\end{array}$ & $\begin{array}{l}2-7 \\
2-7\end{array}$ & $\begin{array}{r}1.0 \\
16.0\end{array}$ & 19.14 & $\begin{array}{l}0.4546 \\
0.4566\end{array}$ & 75.1 & 3.63 & -0.28 & C \\
\hline 607 & $2-7$ & 24.0 & 19.22 & 0.4576 & 81.0 & 3.63 & 0.00 & $\mathrm{U}$ \\
\hline 607 & $3-2$ & 78.0 & 19.22 & 0.4576 & & 3.56 & -0.29 & C \\
\hline 607 & $3-2$ & 91.0 & 19.34 & 0.4612 & 80.1 & 3.39 & -0.45 & C \\
\hline 607 & $3-2$ & 106.0 & 19.49 & 0.4676 & 79.0 & 4.37 & -0.98 & $\mathrm{U}$ \\
\hline 607 & $3-2$ & 119.0 & 19.63 & 0.4723 & & 4.43 & -0.31 & U \\
\hline 607 & $3-2$ & 121.0 & 19.65 & 0.4726 & 86.5 & 4.20 & -0.15 & $\mathrm{U}$ \\
\hline $\begin{array}{l}607 \\
607\end{array}$ & $3-2$ & 136.0 & 19.80 & 0.4747 & 90.3 & 4.01 & -0.05 & U \\
\hline $\begin{array}{l}607 \\
607\end{array}$ & $\begin{array}{l}3-2 \\
3-2\end{array}$ & 136.0 & 19.80 & 0.4747 & & 4.01 & -0.09 & U \\
\hline $\begin{array}{l}607 \\
607\end{array}$ & $\begin{array}{l}3-2 \\
3-3\end{array}$ & & 19.80 & 0.4747 & & 3.30 & 0.72 & C \\
\hline 607 & $\begin{array}{l}3-3 \\
3-3\end{array}$ & $\begin{array}{r}1.0 \\
16.0\end{array}$ & 19.94 & 0.4768 & 90.2 & 3.76 & -0.04 & $\mathrm{U}$ \\
\hline 607 & $3-3$ & & 20.09 & 0.4807 & 91.0 & 3.52 & 0.24 & $\mathrm{U}$ \\
\hline 607 & $3-3$ & $\begin{array}{l}31.0 \\
31.0\end{array}$ & 20.24 & 0.4880 & 90.4 & 3.81 & 0.07 & $\mathrm{U}$ \\
\hline 607 & $3-3$ & $\begin{array}{l}31.0 \\
53.0\end{array}$ & 20.24 & 0.4880 & & 3.20 & 0.92 & C \\
\hline 607 & $3-3$ & $\begin{array}{l}53.0 \\
61.0\end{array}$ & 20.47 & 0.5017 & 85.0 & 3.79 & -0.10 & U \\
\hline 607 & $3-3$ & $\begin{array}{l}61.0 \\
61.0\end{array}$ & 20.55 & 0.5075 & 80.3 & 3.41 & 0.70 & C \\
\hline 607 & $3-3$ & 68.0 & 20.55 & 0.5075 & & 3.88 & -0.69 & $\mathrm{U}$ \\
\hline 607 & $3-3$ & 78.0 & 20.61 & 0.5121 & & 4.24 & -0.91 & U \\
\hline 607 & $3-3$ & 91.0 & 20.72 & 0.5180 & 80.1 & 4.58 & -0.66 & $\mathrm{U}$ \\
\hline 607 & $3-3$ & 106.0 & 20.84 & 0.5277 & 87.6 & 4.53 & -0.44 & $\mathrm{U}$ \\
\hline 607 & $3-3$ & 106.0 & 20.99 & 0.5411 & 82.8 & 3.78 & 0.74 & C \\
\hline 607 & $3-3$ & 121.0 & 20.99 & 0.5411 & & 4.63 & -0.43 & $\mathrm{U}$ \\
\hline 607 & $3-3$ & 121.0 & 21.15 & 0.5521 & 79.3 & 3.43 & -0.07 & C \\
\hline 607 & $3-3$ & 136.0 & 21.15 & 0.5521 & & 4.50 & -0.79 & $\mathrm{U}$ \\
\hline 607 & $3-4$ & $\begin{array}{r}1.0 \\
1.0\end{array}$ & 21.30 & 0.5644 & 84.6 & 3.61 & 0.17 & C \\
\hline 607 & $3-4$ & 16.0 & 21.44 & 0.5735 & 82.1 & 2.76 & 0.83 & C \\
\hline 607 & $3-4$ & 31.0 & 21.59 & 0.5775 & 82.8 & 3.09 & 0.53 & C \\
\hline 607 & $3-4$ & 53.0 & 21.74 & 0.5803 & 77.3 & 3.20 & 0.53 & C \\
\hline 607 & $3-4$ & 61.0 & $\begin{array}{l}21.97 \\
22.05\end{array}$ & 0.5847 & 68.3 & & & \\
\hline 607 & $3-4$ & 61.0 & $\begin{array}{l}22.05 \\
22.05\end{array}$ & 0.5862 & 74.7 & 4.38 & -0.48 & U \\
\hline 607 & $3-4$ & 69.0 & $\begin{array}{l}22.05 \\
22.13\end{array}$ & 0.5862 & & 3.10 & 0.54 & C \\
\hline 607 & $3-4$ & 69.0 & $\begin{array}{l}22.13 \\
22.13\end{array}$ & 0.5887 & & 3.17 & 0.68 & C \\
\hline 607 & $3-4$ & 78.0 & $\begin{array}{l}22.13 \\
22.22\end{array}$ & 0.5887 & & 3.02 & 0.87 & C \\
\hline 607 & $3-4$ & 91.0 & $\begin{array}{l}22.22 \\
22.34\end{array}$ & 0.5914 & 78.8 & 3.02 & 0.94 & C \\
\hline 607 & $4-1$ & 31.0 & $\begin{array}{l}22.34 \\
22.34\end{array}$ & 0.5939 & 83.4 & 2.89 & 0.85 & C \\
\hline 607 & $4-1$ & 53.0 & $\begin{array}{l}22.34 \\
22.55\end{array}$ & 0.5939 & & 3.21 & 0.77 & C \\
\hline 607 & $4-1$ & 61.0 & $\begin{array}{l}22.55 \\
22.63\end{array}$ & 0.6034 & 76.4 & 2.96 & 0.84 & C \\
\hline 607 & $4-1$ & 62.5 & $\begin{array}{l}22.63 \\
22.64\end{array}$ & 0.6074 & & 3.22 & 0.94 & C \\
\hline 607 & $4-1$ & 70.0 & $\begin{array}{l}22.64 \\
22.72\end{array}$ & 0.6077 & 79.0 & & & \\
\hline 607 & $4-1$ & 78.0 & $\begin{array}{l}22.72 \\
22.80\end{array}$ & 0.6093 & & 3.04 & 0.97 & C \\
\hline 607 & $4-1$ & 91.0 & $\begin{array}{l}22.80 \\
22.93\end{array}$ & 0.6103 & 84.4 & 2.95 & 1.04 & C \\
\hline 607 & $4-1$ & 92.5 & $\begin{array}{l}22.93 \\
22.94\end{array}$ & 0.6119 & & 2.84 & 1.02 & C \\
\hline 607 & $4-1$ & 98.0 & $\begin{array}{l}22.94 \\
23.00\end{array}$ & 0.6121 & 85.0 & & & \\
\hline 607 & $4-1$ & 106.0 & $\begin{array}{l}23.00 \\
23.08\end{array}$ & 0.6128 & & 2.88 & 1.14 & C \\
\hline 607 & $4-1$ & 121.0 & $\begin{array}{l}23.08 \\
23.23\end{array}$ & 0.6137 & 81.9 & & & \\
\hline 607 & $4-1$ & 122.5 & $\begin{array}{l}23.23 \\
23.24\end{array}$ & 0.6155 & & 2.49 & 0.66 & C \\
\hline 607 & $4-1$ & 136.0 & $\begin{array}{l}23.24 \\
23.38\end{array}$ & 0.6156 & 80.5 & & & \\
\hline 607 & $4-2$ & 3.5 & $\begin{array}{l}23.38 \\
23.55\end{array}$ & 0.6163 & 79.3 & & & \\
\hline 607 & $4-2$ & 16.0 & $\begin{array}{l}23.55 \\
23.68\end{array}$ & 0.6172 & 78.9 & & & \\
\hline 607 & $4-2$ & 31.0 & $\begin{array}{l}23.68 \\
23.83\end{array}$ & 0.6180 & 77.7 & 3.02 & 0.85 & C \\
\hline 607 & $4-2$ & 32.5 & $\begin{array}{l}23.83 \\
23.84\end{array}$ & 0.6188 & & 2.67 & 0.95 & C \\
\hline 607 & $4-2$ & 53.0 & $\begin{array}{l}23.84 \\
24.05\end{array}$ & 0.6189 & 73.9 & & & \\
\hline 607 & $4-2$ & 61.0 & $\begin{array}{l}24.05 \\
24.13\end{array}$ & 0.6201 & 72.7 & 2.81 & 1.13 & C \\
\hline & & & 24.13 & 0.6207 & & 2.99 & 0.83 & C \\
\hline
\end{tabular}


TABLE A1. (continued)

\begin{tabular}{|c|c|c|c|c|c|c|c|c|}
\hline Hole & Core-section & Depth, $\mathrm{cm}$ & $\begin{array}{c}\text { Composite } \\
\text { Depth, m }\end{array}$ & $\begin{array}{l}\text { Age, } \\
\mathrm{Ma}^{*}\end{array}$ & $\begin{array}{c}\mathrm{CaCO}_{3}, \\
\%\end{array}$ & $\begin{array}{l}\delta^{18} \mathrm{O} \\
\% 0\end{array}$ & $\begin{array}{c}\delta^{13} \mathrm{C}, \\
\% 0\end{array}$ & $\begin{array}{c}\text { Species } \\
\text { Code }^{\dagger}\end{array}$ \\
\hline 607 & $4-2$ & 62.5 & 24.14 & 0.6208 & 69.6 & & & \\
\hline 607 & $4-2$ & 78.0 & 24.30 & 0.6219 & 63.4 & 3.35 & 0.19 & $\mathrm{C}$ \\
\hline 607 & $4-2$ & 91.0 & 24.43 & 0.6229 & & 3.44 & 0.08 & $\mathrm{C}$ \\
\hline 607 & $4-2$ & 92.5 & 24.44 & 0.6230 & 55.1 & & & \\
\hline 607 & $4-2$ & 106.0 & 24.58 & 0.6242 & 52.7 & & & \\
\hline 607 & $4-2$ & 122.5 & 24.74 & 0.6256 & 46.5 & & & \\
\hline 607 & $4-2$ & 136.0 & 24.88 & 0.6267 & 58.5 & 5.20 & -1.18 & $\mathrm{U}$ \\
\hline 607 & $4-2$ & 136.0 & 24.88 & 0.6267 & & 4.17 & 0.03 & $\mathrm{C}$ \\
\hline 607 & $4-3$ & 3.5 & 25.06 & 0.6298 & 65.0 & & & \\
\hline 607 & $4-3$ & 16.0 & 25.18 & 0.6320 & 56.0 & & & \\
\hline 607 & $4-3$ & 31.0 & 25.33 & 0.6346 & & 4.34 & 0.80 & $\mathrm{C}$ \\
\hline 607 & $4-3$ & 32.5 & 25.34 & 0.6353 & 61.5 & & & \\
\hline 607 & $4-3$ & 53.0 & 25.55 & 0.6445 & 56.3 & 4.03 & -0.04 & C \\
\hline 607 & $4-3$ & 61.0 & 25.63 & 0.6476 & & 4.81 & -0.66 & $\mathrm{U}$ \\
\hline 607 & $4-3$ & 61.0 & 25.63 & 0.6476 & & 4.07 & -0.10 & $\mathrm{C}$ \\
\hline 607 & $4-3$ & 63.5 & 25.65 & 0.6482 & 57.5 & & & \\
\hline 607 & $4-3$ & 78.0 & 25.80 & 0.6517 & 65.0 & 4.01 & -0.39 & C \\
\hline 607 & $4-3$ & 93.5 & 25.95 & 0.6548 & 65.7 & & & 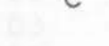 \\
\hline 607 & $4-3$ & 106.0 & 26.08 & 0.6573 & 64.3 & & & \\
\hline 607 & $4-3$ & 122.5 & 26.24 & 0.6606 & 70.2 & & & \\
\hline 607 & $4-3$ & 136.0 & 26.38 & 0.6633 & 59.2 & & & \\
\hline 607 & $4-4$ & 1.0 & 26.53 & 0.6663 & & 3.96 & 0.13 & C \\
\hline 607 & $4-4$ & 3.5 & 26.56 & 0.6667 & 69.1 & & & \\
\hline 607 & $4-4$ & 16.0 & 26.68 & 0.6691 & 63.1 & 3.91 & -0.09 & C \\
\hline 607 & $4-4$ & 31.0 & 26.83 & 0.6719 & & 3.95 & -0.17 & C \\
\hline 607 & $4-4$ & 33.5 & 26.85 & 0.6723 & 61.3 & & & \\
\hline 607 & $4-4$ & 53.0 & 27.05 & 0.6750 & 63.7 & 4.51 & -0.77 & $\mathrm{U}$ \\
\hline 607 & $4-4$ & 61.0 & 27.13 & 0.6758 & & 4.44 & -0.98 & $\mathrm{U}$ \\
\hline 607 & $4-4$ & 63.5 & 27.15 & 0.6760 & 64.2 & & & \\
\hline 607 & $4-4$ & 78.0 & 27.30 & 0.6774 & 70.3 & & & \\
\hline 607 & $4-4$ & 91.0 & 27.43 & 0.6788 & & 3.29 & 0.43 & C \\
\hline 607 & $4-4$ & 92.5 & 27.44 & 0.6790 & 77.3 & & & \\
\hline 607 & $4-4$ & 106.0 & 27.58 & 0.6805 & 75.1 & 3.20 & 0.68 & C \\
\hline 607 & $4-4$ & 119.5 & 27.72 & 0.6822 & 73.7 & & & \\
\hline 607 & $4-4$ & 121.0 & 27.73 & 0.6824 & & 3.14 & 0.69 & C \\
\hline 607 & $4-4$ & 136.0 & 27.88 & 0.6844 & 85.6 & 3.08 & 1.05 & C \\
\hline 607 & $4-5$ & 1. 0 & 28.03 & 0.6864 & & 2.92 & 0.98 & C \\
\hline 607 & $4-5$ & 3.5 & 28.06 & 0.6867 & 86.5 & & & \\
\hline 607 & $4-5$ & 16.0 & 28.18 & 0.6884 & 84.8 & 2.83 & 1.19 & C \\
\hline 607 & $4-5$ & 29.5 & 28.31 & 0.6899 & 86.1 & & & \\
\hline 607 & $4-5$ & 31.0 & 28.33 & 0.6900 & & 2.78 & 0.92 & C \\
\hline 607 & $4-5$ & 53.0 & 28.55 & 0.6921 & 80.7 & 2.95 & 0.80 & C \\
\hline 607 & $4-5$ & 59.5 & 28.61 & 0.6927 & 80.7 & & & \\
\hline 607 & $4-5$ & 61.0 & 28.63 & 0.6928 & & 3.00 & 1.17 & C \\
\hline 607 & $4-5$ & 78.0 & 28.80 & 0.6946 & 63.6 & 3.93 & -1.11 & $\mathrm{U}$ \\
\hline 607 & $4-5$ & 89.5 & 28.91 & 0.6961 & 38.5 & & & \\
\hline 607 & $4-5$ & 91.0 & 28.93 & 0.6963 & & 4.38 & -1.31 & $\mathrm{U}$ \\
\hline 607 & $4-5$ & 106.0 & 29.08 & 0.6982 & 52.0 & 4.53 & -1.45 & U \\
\hline 607 & $4-5$ & 120.5 & 29.22 & 0.7002 & 55.4 & & & \\
\hline 607 & $4-5$ & 121.0 & 29.23 & 0.7002 & & 4.57 & -1.11 & $\mathrm{U}$ \\
\hline 607 & $4-5$ & 121.0 & 29.23 & 0.7002 & & 3.93 & -0.29 & C \\
\hline 607 & $4-5$ & 136.0 & 29.38 & 0.7021 & 66.2 & 4.44 & -1.07 & $\mathrm{U}$ \\
\hline 607 & $4-6$ & 1.0 & 29.53 & 0.7039 & & 4.42 & -1.16 & $\mathrm{U}$ \\
\hline 607 & $4-6$ & 3.5 & 29.55 & 0.7042 & 72.9 & & & \\
\hline 607 & $4-6$ & 16.0 & 29.68 & 0.7058 & 77.5 & 4.05 & -0.63 & $\mathrm{U}$ \\
\hline 607 & $4-6$ & 29.5 & 29.81 & 0.7076 & 77.7 & & & \\
\hline 607 & $4-6$ & 31.0 & 29.83 & 0.7078 & & 2.98 & 0.93 & C \\
\hline
\end{tabular}


TABLE A1. (continued)

\begin{tabular}{|c|c|c|c|c|c|c|c|c|}
\hline Hole & Core-section & Depth, cm & $\begin{array}{c}\text { Composite } \\
\text { Depth, m }\end{array}$ & $\begin{array}{l}\text { Age, } \\
\mathrm{Ma}^{*}\end{array}$ & $\begin{array}{c}\mathrm{CaCO}_{3}, \\
\%\end{array}$ & $\begin{array}{l}\delta^{18} \mathrm{O}, \\
\% 00\end{array}$ & $\begin{array}{c}\delta^{13} \mathrm{C} \\
\%\end{array}$ & $\begin{array}{c}\text { Species } \\
\text { Codet }\end{array}$ \\
\hline 607 & $4-6$ & 53.0 & 30.05 & 0.7108 & 75.6 & 3.38 & 0.82 & C \\
\hline 607 & $4-6$ & 59.5 & 30.11 & 0.7116 & 77.8 & & & \\
\hline 607 & $4-6$ & 61.0 & 30.13 & 0.7118 & & 4.16 & -1.00 & $\mathrm{U}$ \\
\hline $\begin{array}{l}607 \\
607\end{array}$ & $4-6$ & 61.0 & 30.13 & 0.7118 & & 3.26 & 0.86 & C \\
\hline $\begin{array}{l}607 \\
607\end{array}$ & $4-6$ & 78.0 & $30 \cdot 30$ & 0.7137 & 63.6 & 4.51 & -1.47 & U \\
\hline $\begin{array}{l}607 \\
607\end{array}$ & $4-6$ & 78.0 & $30 \cdot 30$ & 0.7137 & & 3.02 & -0.27 & C \\
\hline $\begin{array}{l}607 \\
607\end{array}$ & $4-6$ & 91.0 & 30.43 & 0.7153 & & 4.47 & -1.27 & U \\
\hline $\begin{array}{l}607 \\
607\end{array}$ & $4-6$ & 91.0 & 30.43 & 0.7153 & & 3.72 & -0.77 & C \\
\hline $\begin{array}{l}607 \\
607\end{array}$ & $\begin{array}{l}4-6 \\
4-6\end{array}$ & 92.5 & 30.44 & 0.7154 & 54.7 & & & \\
\hline 607 & & 106.0 & 30.58 & $\begin{array}{l}0.7170 \\
0.7182\end{array}$ & 60.5 & 4.55 & -1.40 & U \\
\hline 607 & $\begin{array}{l}4-6 \\
4-6\end{array}$ & & 30.72 & & 61.7 & & & \\
\hline 607 & $\begin{array}{l}4-6 \\
4-6\end{array}$ & $\begin{array}{l}121.0 \\
136.0\end{array}$ & $\begin{array}{l}30.73 \\
30.88\end{array}$ & & & $\begin{array}{l}4.53 \\
4.48\end{array}$ & -1.27 & U \\
\hline 607 & $4-7$ & $\begin{array}{r}136.0 \\
1.0\end{array}$ & $\begin{array}{l}30.88 \\
31.03\end{array}$ & $\begin{array}{l}0.7195 \\
0.7209\end{array}$ & 64.8 & $\begin{array}{l}4.48 \\
4.37\end{array}$ & -1.01 & 0 \\
\hline 607 & $4-7$ & $\begin{array}{l}1.0 \\
5.5\end{array}$ & 31.07 & & 59.2 & 4.31 & -1.14 & $\mathrm{U}$ \\
\hline 607 & $4-7$ & 16.0 & 31.18 & 0.7226 & 71.0 & 4.32 & & \\
\hline 607 & $4-7$ & 24.0 & 31.26 & 0.7236 & 65.7 & 4.20 & -1.19 & 0 \\
\hline $607 \mathrm{~A}$ & $5-4$ & 121.0 & 31.42 & 0.7254 & 81.7 & & -0.91 & U \\
\hline $607 A$ & $5-4$ & 135.0 & 31.56 & 0.7270 & 88.2 & 3.32 & & \\
\hline $607 \mathrm{~A}$ & $5-5$ & 1.0 & 31.72 & 0.7289 & 86.9 & 2.94 & 0.26 & C \\
\hline $607 \mathrm{~A}$ & $5-5$ & 15.0 & 31.86 & 0.7330 & 89.8 & & 0.70 & C \\
\hline $607 A$ & $5-5$ & 31.0 & 32.02 & 0.7377 & 81.8 & 3.16 & & \\
\hline $607 \mathrm{~A}$ & $5-5$ & 31.0 & 32.02 & 0.7377 & & 3.06 & $\begin{array}{r}-0.08 \\
0.23\end{array}$ & C \\
\hline $607 \mathrm{~A}$ & $5-5$ & 45.0 & 32.16 & 0.7429 & 61.7 & 3.64 & $\begin{array}{r}0.23 \\
-0.43\end{array}$ & C \\
\hline $607 \mathrm{~A}$ & $5-5$ & 61.0 & 32.32 & 0.7488 & 67.4 & 4.14 & $\begin{array}{l}-0.43 \\
-0.63\end{array}$ & C \\
\hline $607 A$ & $5-5$ & 61.0 & 32.32 & 0.7488 & & 4.66 & $\begin{array}{l}-0.63 \\
-1.10\end{array}$ & C \\
\hline $607 A$ & $5-5$ & 75.0 & 32.46 & 0.7512 & 73.7 & & -1.10 & U \\
\hline 607 & $5-1$ & 16.0 & 32.62 & 0.7538 & 75.9 & 3.83 & -0.54 & \\
\hline 607 & $5-1$ & 22.0 & 32.68 & 0.7545 & & 3.68 & -0.56 & $\begin{array}{l}C \\
C\end{array}$ \\
\hline 607 & $5-1$ & 29.5 & 32.76 & 0.7554 & 79.1 & & & C \\
\hline 607 & $5-1$ & 31.0 & 32.77 & 0.7556 & & 3.88 & -0.25 & \\
\hline 607 & $5-1$ & 53.0 & 32.99 & 0.7581 & 84.3 & 3.52 & 0.25 & $\begin{array}{l}\mathrm{C} \\
\mathrm{C}\end{array}$ \\
\hline 607 & $5-1$ & 61.0 & 33.07 & 0.7590 & 83.7 & 3.55 & 0.34 & C \\
\hline 607 & $5-1$ & 61.5 & 33.08 & 0.7590 & 83.7 & & 0.34 & C \\
\hline 607 & $5-1$ & 78.0 & 33.24 & 0.7609 & 90.1 & 3.10 & 0.67 & \\
\hline 607 & $5-1$ & 89.5 & 33.35 & 0.7623 & 89.2 & & & C \\
\hline 607 & $5-1$ & 93.0 & 33.39 & 0.7627 & & 3.03 & 0.55 & C \\
\hline 607 & $5-1$ & 106.0 & 33.52 & 0.7649 & 86.8 & 3.10 & 0.41 & C \\
\hline 607 & $5-1$ & 117.5 & 33.63 & 0.7676 & 86.3 & & & \\
\hline 607 & $5-1$ & 119.0 & 33.65 & 0.7679 & 86.0 & 3.17 & 0.43 & C \\
\hline 607 & $5-1$ & 136.0 & 33.82 & 0.7719 & & 3.19 & 0.77 & C \\
\hline 607 & $5-1$ & 138.5 & 33.84 & 0.7725 & 88.2 & & & \\
\hline 607 & $\begin{array}{l}5-2 \\
5-2\end{array}$ & 1. 0 & 33.97 & 0.7755 & & 2.92 & 0.69 & C \\
\hline $\begin{array}{l}607 \\
607\end{array}$ & $\begin{array}{l}5-2 \\
5-2\end{array}$ & 3.5 & 33.99 & 0.7760 & 89.7 & & & \\
\hline $\begin{array}{l}607 \\
607\end{array}$ & $\begin{array}{l}5-2 \\
5-2\end{array}$ & 16.0 & 34.12 & 0.7789 & 82.4 & 3.63 & -0.29 & U \\
\hline $\begin{array}{l}607 \\
607\end{array}$ & $\begin{array}{l}5-2 \\
5-2\end{array}$ & $\begin{array}{l}16.0 \\
30.5\end{array}$ & 34.12 & 0.7789 & 865 & 2.80 & 0.48 & C \\
\hline 607 & $5-2$ & $\begin{array}{l}30.5 \\
31.0\end{array}$ & $\begin{array}{l}34.26 \\
34.27\end{array}$ & $\begin{array}{l}0.7819 \\
0.7820\end{array}$ & 86.5 & 2.69 & 0.68 & \\
\hline 607 & $5-2$ & 53.0 & $\begin{array}{l}34.27 \\
34.49\end{array}$ & $\begin{array}{l}0.7820 \\
0.7862\end{array}$ & 77.4 & $\begin{array}{l}2.09 \\
3.03\end{array}$ & -0.34 & $\begin{array}{l}\mathrm{C} \\
\mathrm{C}\end{array}$ \\
\hline 607 & $5-2$ & 58.5 & 34.54 & 0.7873 & 66.7 & & & \\
\hline 607 & $5-2$ & 61.0 & 34.57 & 0.7878 & & 3.58 & -0.39 & C \\
\hline 607 & $5-2$ & 78.0 & 34.74 & 0.7912 & 57.3 & 3.21 & 0.31 & C \\
\hline 607 & $5-2$ & 89.5 & 34.85 & 0.7935 & 60.7 & & & \\
\hline 607 & $5-2$ & 91.0 & 34.87 & 0.7938 & & 4.64 & -1.65 & $\mathrm{U}$ \\
\hline 607 & $5-2$ & 106.0 & 35.02 & 0.7963 & 58.8 & & & \\
\hline 607 & $5-2$ & 119.5 & 35.15 & 0.7986 & 60.8 & 3.76 & -0.37 & C \\
\hline $\begin{array}{l}607 \\
607\end{array}$ & $\begin{array}{l}5-2 \\
5-2\end{array}$ & $\begin{array}{l}121.0 \\
136.0\end{array}$ & $\begin{array}{l}35.17 \\
35.32\end{array}$ & $\begin{array}{l}0.7988 \\
0.8012\end{array}$ & 51.8 & 3.76 & -0.31 & \\
\hline
\end{tabular}


TABLE A1. (continued)

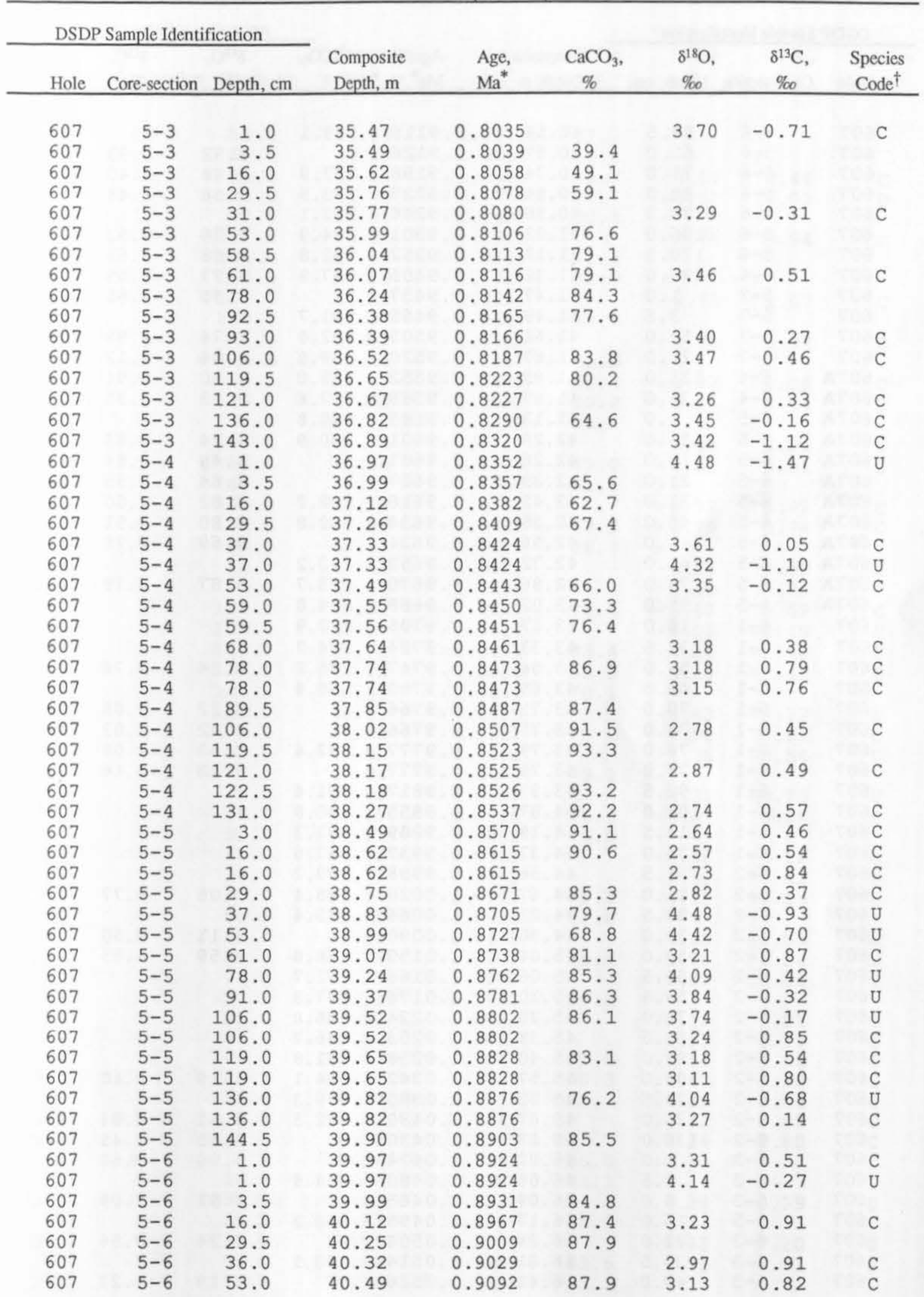


TABLE A1. (continued)

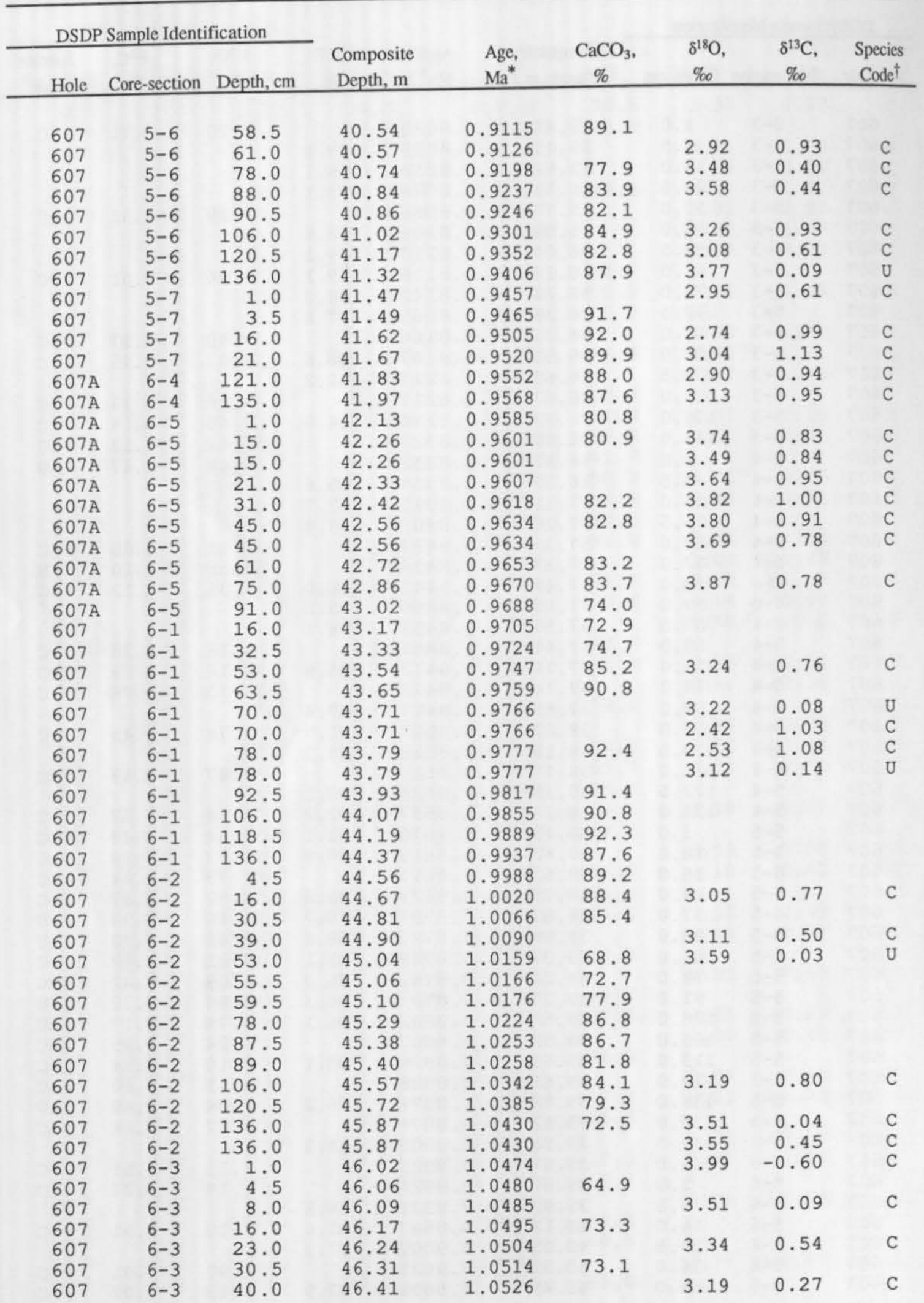


TABLE A1. (continued)

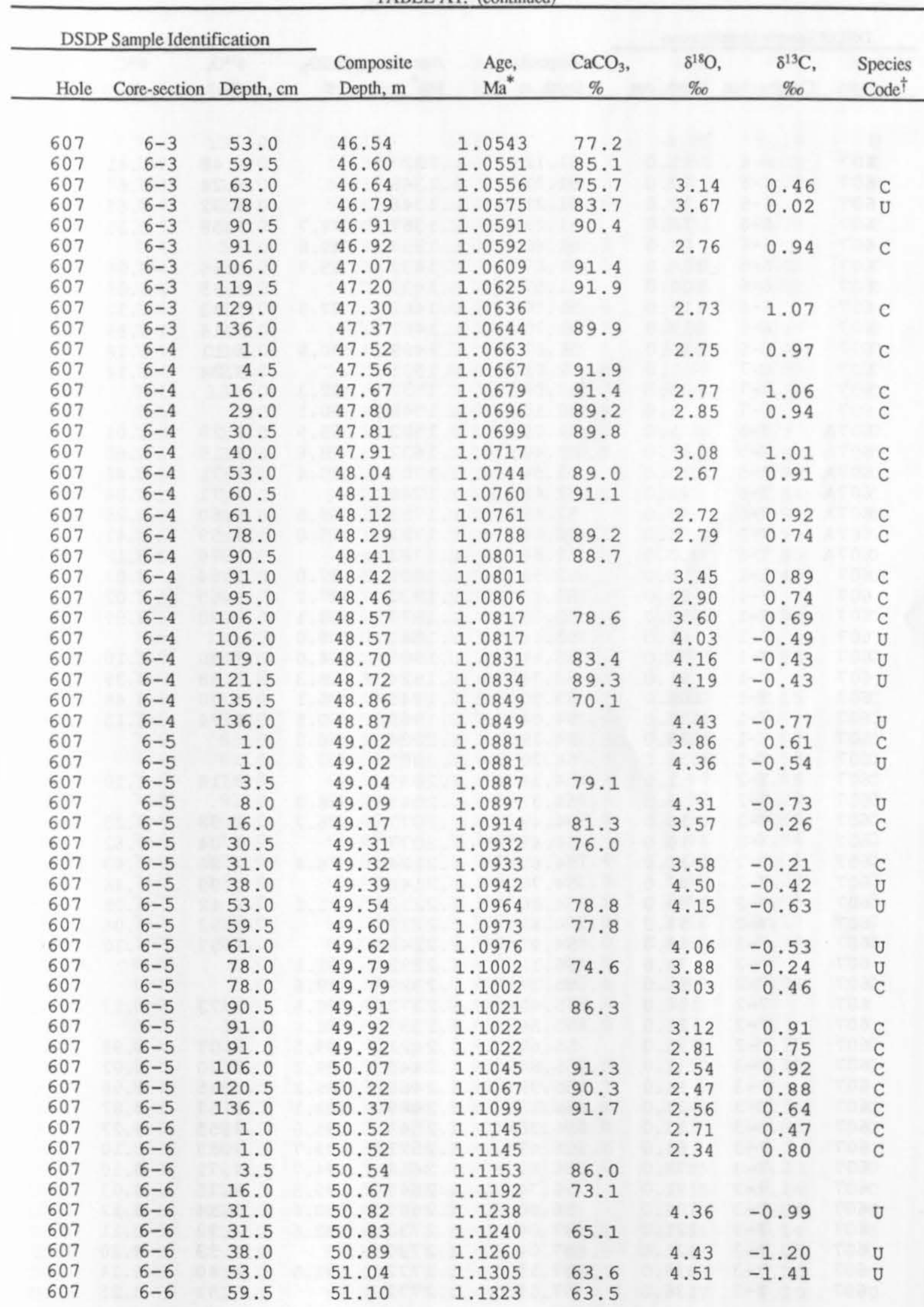


TABLE A1. (continued)

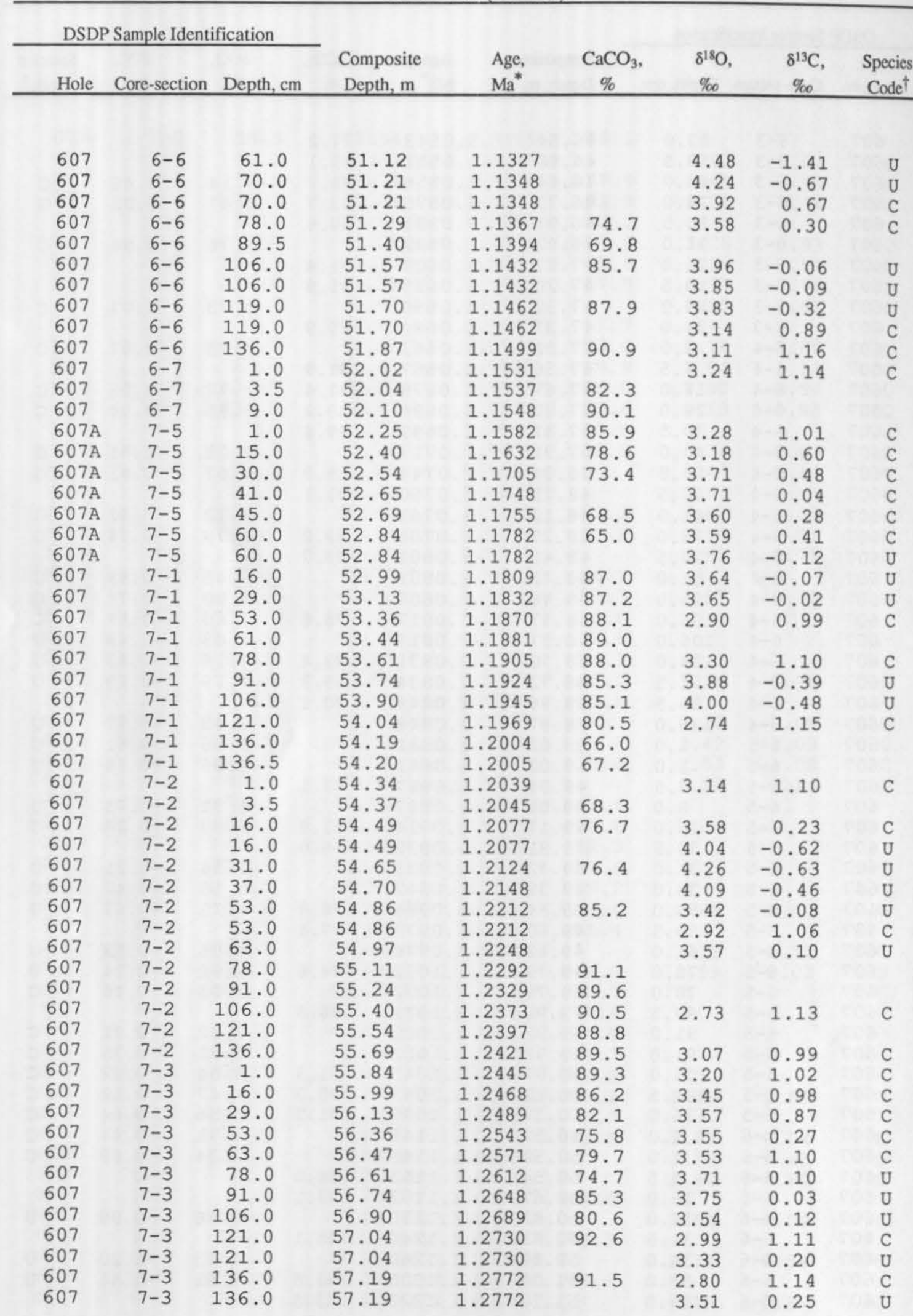


TABLE A1. (continued)

\begin{tabular}{|c|c|c|c|c|c|c|c|c|}
\hline \multicolumn{3}{|c|}{ DSDP Sample Identification } & \multirow[b]{2}{*}{$\begin{array}{l}\text { Composite } \\
\text { Depth, m }\end{array}$} & \multirow[b]{2}{*}{$\begin{array}{l}\text { Age, } \\
\mathrm{Ma}^{*}\end{array}$} & \multirow[b]{2}{*}{$\begin{array}{c}\mathrm{CaCO}_{3}, \\
\%\end{array}$} & \multirow[b]{2}{*}{$\begin{array}{l}\delta^{18} \mathrm{O} \\
\% 0\end{array}$} & \multirow[b]{2}{*}{$\begin{array}{c}\delta^{13} \mathrm{C}, \\
\% 0\end{array}$} & \multirow[b]{2}{*}{$\begin{array}{c}\text { Species } \\
\text { Code }\end{array}$} \\
\hline Hole & Core-section & Depth, $\mathrm{cm}$ & & & & & & \\
\hline 607 & $7-3$ & 136.0 & 57.19 & 1.2772 & & 3.20 & 0.19 & $\mathrm{U}$ \\
\hline 607 & $7-4$ & 1.0 & 57.34 & 1.2786 & 86.3 & 2.95 & 1.05 & $\mathrm{C}$ \\
\hline 607 & $7-4$ & 16.0 & 57.49 & 1.2857 & 88.3 & 3.41 & 1.04 & $\mathrm{C}$ \\
\hline 607 & $7-4$ & 29.0 & 57.63 & 1.2894 & 85.6 & & & \\
\hline 607 & $7-4$ & 33.0 & 57.66 & 1.2905 & & 3.51 & 0.72 & C \\
\hline 607 & $7-4$ & 53.0 & 57.86 & 1.2958 & 80.5 & & & \\
\hline 607 & $7-4$ & 59.0 & 57.92 & 1.2975 & 82.1 & 3.24 & 0.42 & C \\
\hline 607 & $7-4$ & 69.0 & 58.02 & 1.3001 & & 3.46 & 0.61 & C \\
\hline 607 & $7-4$ & 78.0 & 58.11 & 1.3024 & 86.0 & & & \\
\hline 607 & $7-4$ & 91.0 & 58.24 & 1.3058 & 87.7 & 2.98 & 1.09 & C \\
\hline 607 & $7-4$ & 106.0 & 58.40 & 1.3097 & 95.0 & 2.59 & 1.06 & C \\
\hline 607 & $7-4$ & 121.0 & 58.54 & 1.3135 & 92.5 & 2.69 & 1.03 & C \\
\hline 607 & $7-4$ & 136.0 & 58.69 & 1.3172 & 92.7 & 2.84 & 0.46 & C \\
\hline 607 & $7-5$ & 1.0 & 58.84 & 1.3213 & 90.8 & & & \\
\hline 607 & $7-5$ & 16.0 & 58.99 & 1.3254 & 82.6 & 4.04 & -0.97 & $\mathrm{U}$ \\
\hline 607 & $7-5$ & 30.0 & 59.13 & 1.3314 & 59.8 & 3.48 & 0.01 & C \\
\hline 607 & $7-5$ & 30.0 & 59.13 & 1.3314 & & 4.40 & -0.98 & U \\
\hline 607 & $7-5$ & 37.0 & 59.20 & 1.3355 & 64.1 & 3.00 & 0.24 & C \\
\hline 607 & $7-5$ & 37.0 & 59.20 & 1.3355 & & 4.23 & -0.94 & $\mathrm{U}$ \\
\hline 607 & $7-5$ & 53.0 & 59.36 & 1.3420 & 68.3 & 4.38 & -0.90 & U \\
\hline 607 & $7-5$ & 61.0 & 59.44 & 1.3439 & 72.4 & 4.34 & -0.80 & $\mathrm{U}$ \\
\hline 607 & $7-5$ & 78.0 & 59.61 & 1.3468 & 79.3 & 4.11 & -0.46 & $\mathrm{U}$ \\
\hline 607 & $7-5$ & 91.0 & 59.74 & 1.3485 & 84.3 & & & \\
\hline 607 & $7-5$ & 106.0 & 59.90 & 1.3504 & 89.5 & 2.92 & 0.98 & C \\
\hline 607 & $7-5$ & 121.0 & 60.04 & 1.3523 & 89.5 & & & \\
\hline 607 & $7-5$ & 136.0 & 60.19 & 1.3543 & 92.1 & 2.67 & 0.89 & $\mathrm{C}$ \\
\hline 607 & $7-6$ & 1.0 & 60.34 & 1.3566 & 91.0 & & & \\
\hline 607 & $7-6$ & 16.0 & 60.49 & 1.3590 & 92.2 & 2.70 & 1.15 & C \\
\hline 607 & $7-6$ & 31.0 & 60.65 & 1.3616 & 86.5 & 2.74 & 0.77 & C \\
\hline 607 & $7-6$ & 53.0 & 60.86 & 1.3653 & 73.5 & 3.63 & 0.57 & C \\
\hline 607 & $7-6$ & 61.0 & 60.94 & 1.3667 & 74.5 & 3.73 & 0.53 & C \\
\hline 607 & $7-6$ & 78.0 & 61.11 & 1.3711 & 77.9 & 3.80 & 0.56 & C \\
\hline 607 & $7-6$ & 91.0 & 61.24 & 1.3756 & 76.4 & 3.58 & 0.29 & C \\
\hline 607 & $7-6$ & 106.0 & 61.40 & 1.3807 & 82.5 & 3.36 & 0.60 & C \\
\hline 607 & $7-6$ & 114.0 & 61.47 & 1.3832 & & 3.44 & 0.96 & C \\
\hline 607 & $7-6$ & 121.0 & 61.54 & 1.3852 & 87.4 & 3.36 & 1.01 & C \\
\hline 607 & $7-6$ & 136.0 & 61.69 & 1.3893 & 91.3 & 3.00 & 1.22 & C \\
\hline 607 & $7-7$ & 1. 0 & 61.84 & 1.3935 & 91.1 & 2.94 & 1.05 & C \\
\hline 607 & $7-7$ & 16.0 & 61.99 & 1.3976 & 92.2 & 3.02 & 1.17 & C \\
\hline 607 & $7-7$ & 24.0 & 62.07 & 1.3998 & 89.9 & 2.98 & 0.94 & C \\
\hline $607 \mathrm{~A}$ & $8-5$ & 1.0 & 62.23 & 1.4040 & 84.7 & & & \\
\hline 607 & $8-1$ & 5.0 & 62.38 & 1.4078 & 80.4 & 3.63 & 0.04 & C \\
\hline 607 & $8-1$ & 16.0 & 62.48 & 1.4104 & 76.3 & & & \\
\hline 607 & $8-1$ & 31.0 & 62.63 & 1.4140 & 74.0 & & & \\
\hline 607 & $8-1$ & 38.0 & 62.70 & 1.4157 & & 3.78 & 0.13 & C \\
\hline 607 & $8-1$ & 53.0 & 62.85 & 1.4172 & 78.2 & 3.57 & 0.10 & C \\
\hline 607 & $8-1$ & 61.0 & 62.93 & 1.4181 & 82.1 & & & \\
\hline 607 & $8-1$ & 78.0 & 63.10 & 1.4199 & 86.8 & 3.44 & 0.76 & C \\
\hline 607 & $8-1$ & 89.0 & 63.22 & 1.4212 & 90.8 & 3.27 & 0.88 & C \\
\hline 607 & $8-1$ & 106.0 & 63.38 & 1.4228 & 81.6 & & & \\
\hline 607 & $8-1$ & 121.0 & 63.53 & 1.4242 & 86.4 & 3.85 & 0.23 & $\mathrm{U}$ \\
\hline 607 & $8-1$ & 121.0 & 63.53 & 1.4242 & & 3.35 & 1.16 & C \\
\hline 607 & $8-1$ & 129.0 & 63.61 & 1.4251 & & 3.70 & 0.06 & $\mathrm{U}$ \\
\hline 607 & $8-1$ & 136.0 & 63.68 & 1.4260 & 92.1 & 3.54 & 0.14 & $\mathrm{U}$ \\
\hline 607 & $8-2$ & 3.0 & 63.85 & 1.4281 & 92.9 & 3.44 & 0.05 & $\mathrm{U}$ \\
\hline 607 & $8-2$ & 16.0 & 63.98 & 1.4335 & 93.7 & 3.00 & 1.20 & C \\
\hline 607 & $8-2$ & 16.0 & 63.98 & 1. 4335 & & 3.37 & 0.20 & $\mathrm{U}$ \\
\hline
\end{tabular}


TABLE A1. (continued)

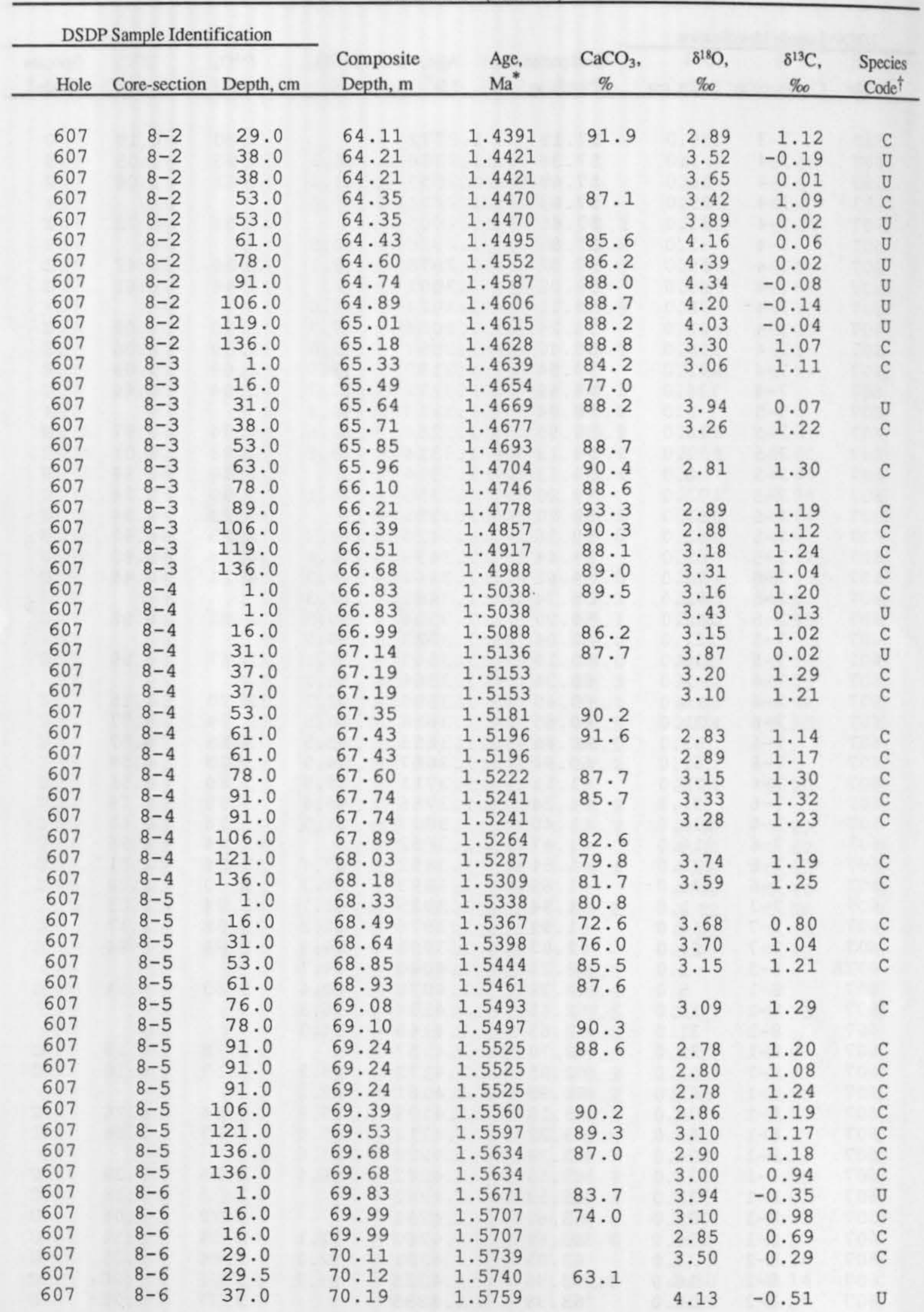


TABLE A1. (continued)

\begin{tabular}{|c|c|c|c|c|c|c|c|c|}
\hline \multicolumn{3}{|c|}{ DSDP Sample Identification } & \multirow[b]{2}{*}{$\begin{array}{l}\text { Composite } \\
\text { Depth, m }\end{array}$} & \multirow[b]{2}{*}{$\begin{array}{l}\text { Age, } \\
\mathrm{Ma}^{*}\end{array}$} & \multirow[b]{2}{*}{$\begin{array}{c}\mathrm{CaCO}_{3}, \\
\%\end{array}$} & \multirow[b]{2}{*}{$\begin{array}{l}\delta^{18} \mathrm{O} \\
\% \\
\end{array}$} & \multirow[b]{2}{*}{$\begin{array}{c}\delta^{13} \mathrm{C}, \\
\% 0\end{array}$} & \multirow[b]{2}{*}{$\begin{array}{c}\text { Species } \\
\text { Code }^{\dagger} \\
\end{array}$} \\
\hline Hole & Core-section & Depth, $\mathrm{cm}$ & & & & & & \\
\hline 607 & $8-6$ & 37.0 & 70.19 & 1.5759 & & 4.36 & -0.30 & $\mathrm{U}$ \\
\hline 607 & $8-6$ & 53.0 & 70.35 & 1.5790 & 70.4 & 3.10 & 0.56 & C \\
\hline 607 & $8-6$ & 61.0 & 70.43 & 1.5806 & 75.5 & 2.92 & 0.94 & C \\
\hline 607 & $8-6$ & 78.0 & 70.60 & 1.5838 & 86.0 & 2.86 & 0.90 & C \\
\hline 607 & $8-6$ & 78.0 & 70.60 & 1. 5838 & & 3.58 & -0.15 & $\mathrm{U}$ \\
\hline 607 & $8-6$ & 89.0 & 70.71 & 1.5860 & 81.3 & 3.21 & 0.74 & C \\
\hline 607 & $8-6$ & 89.0 & 70.71 & 1.5860 & & 3.60 & -0.21 & $\mathrm{U}$ \\
\hline 607 & $8-6$ & 106.0 & 70.89 & 1.5892 & 82.0 & 4.08 & -0.50 & $\mathrm{U}$ \\
\hline 607 & $8-6$ & 121.0 & 71.03 & 1.5921 & 85.5 & 3.05 & 0.89 & C \\
\hline 607 & $8-6$ & 136.0 & 71.18 & 1.5950 & 86.4 & 3.07 & 0.63 & C \\
\hline 607 & $8-6$ & 136.0 & 71.18 & 1.5950 & & 3.71 & -0.26 & $\mathrm{U}$ \\
\hline 607 & $8-6$ & 136.0 & 71.18 & 1.5950 & & 3.17 & 1.03 & C \\
\hline 607 & $8-7$ & 1.0 & 71.33 & 1.5979 & 81.2 & & & \\
\hline 607 & $8-7$ & 5.0 & 71.38 & 1.5987 & 80.4 & 2.87 & 0.96 & C \\
\hline 607 & $8-7$ & 5.0 & 71.38 & 1.5987 & & 2.84 & 0.86 & C \\
\hline $607 \mathrm{~A}$ & $9-4$ & 75.0 & 71.54 & 1.6020 & 70.1 & & & \\
\hline $607 \mathrm{~A}$ & $9-4$ & 91.0 & 71.71 & 1.6051 & 76.1 & 3.22 & 0.86 & C \\
\hline $607 \mathrm{~A}$ & $9-4$ & 105.0 & 71.85 & 1.6078 & 70.7 & & & \\
\hline $607 \mathrm{~A}$ & $9-4$ & 121.0 & 72.00 & 1.6108 & 88.8 & 3.90 & 0.06 & U \\
\hline $607 \mathrm{~A}$ & $9-4$ & 135.0 & 72.14 & 1.6144 & 78.5 & 3.18 & 0.71 & C \\
\hline $607 \mathrm{~A}$ & $9-4$ & 135.0 & 72.14 & 1.6144 & & 3.75 & -0.10 & $\mathrm{U}$ \\
\hline $607 \mathrm{~A}$ & $9-5$ & 1.0 & 72.31 & 1.6185 & 85.7 & 4.07 & -0.73 & U \\
\hline $607 \mathrm{~A}$ & $9-5$ & 15.0 & 72.44 & 1.6223 & 75.3 & 3.84 & -0.63 & U \\
\hline $607 . A$ & $9-5$ & 30.0 & 72.60 & 1.6264 & 84.4 & 4.13 & -0.28 & $\mathrm{U}$ \\
\hline 607 & $9-1$ & 1.0 & 72.71 & 1.6295 & 92.6 & & & \\
\hline 607 & $9-1$ & 16.0 & 72.85 & 1.6338 & 93.8 & 2.73 & 0.99 & C \\
\hline 607 & $9-1$ & 31.0 & 73.00 & 1.6375 & & 2.76 & 1.23 & C \\
\hline 607 & $9-1$ & 53.0 & 73.22 & 1.6426 & 90.7 & 2.90 & 1.07 & C \\
\hline
\end{tabular}

* Ages based on TP607 time scale.

† C, Cibicidoides; U, Uvigerina. Isotope data not corrected for species offsets.

TABLE A2. Percentages of Species Used in Transfer Function F13x5, and Summer and Winter Temperature Estimates for Site 607

\begin{tabular}{|c|c|c|c|c|c|c|c|c|c|c|}
\hline \multicolumn{3}{|c|}{$\begin{array}{l}\text { DSDP Sample } \\
\text { Identification }\end{array}$} & \multirow[b]{2}{*}{$\begin{array}{c}\text { Composite } \\
\text { Depth, m }\end{array}$} & \multirow[b]{2}{*}{$\begin{array}{l}\text { Age, } \\
\mathrm{Ma}^{*}\end{array}$} & \multirow[b]{2}{*}{$\begin{array}{c}\text { Species } \\
1 \\
\end{array}$} & \multirow[b]{2}{*}{$\begin{array}{c}\text { Species } \\
2 \\
\end{array}$} & \multirow[b]{2}{*}{$\begin{array}{c}\text { Species } \\
3 \\
\end{array}$} & \multirow[b]{2}{*}{$\begin{array}{c}\text { Species } \\
4 \\
\end{array}$} & \multirow[b]{2}{*}{$\begin{array}{l}\text { SSTs, } \\
{ }^{\circ} \mathrm{C}\end{array}$} & \multirow[b]{2}{*}{$\begin{array}{l}\text { SSTw, } \\
{ }^{\circ} \mathrm{C}\end{array}$} \\
\hline Hole & $\begin{array}{l}\text { Core- } \\
\text { section }\end{array}$ & $\begin{array}{c}\text { Depth, } \\
\mathrm{cm}\end{array}$ & & & & & & & & \\
\hline $607 \mathrm{~A}$ & $2-3$ & 45.0 & 9.32 & 0.2453 & 3.1 & 24.3 & 10.7 & & & 8.8 \\
\hline $607 \mathrm{~A}$ & $2-3$ & 61. & & 0.24 & 3. & & & 12. & & 10. \\
\hline $607 \mathrm{~A}$ & $2-3$ & 75. & 9.62 & 0.25 & 1. & & & 12. & 17 & 11. \\
\hline $607 \mathrm{~A}$ & $2-3$ & 91. & 9.78 & 0.25 & 0.5 & & 0 . & 12. & & 12. \\
\hline $607 \mathrm{~A}$ & $2-3$ & 105.0 & 9.92 & 0.2530 & 1.6 & & & 6. & & 10. \\
\hline $607 \mathrm{~A}$ & $2-3$ & 121.0 & 10.08 & 0.2541 & 3.0 & 17.4 & 11.4 & 8. & 1 & 10. \\
\hline $607 \mathrm{~A}$ & $2-3$ & 135.0 & 10.22 & 0.2551 & 5.8 & 19.5 & 4.2 & 4. & 18 & 12. \\
\hline $607 \mathrm{~A}$ & $2-4$ & 1.0 & 10.38 & 0.2564 & 1.2 & 16.4 & 18.7 & 9. & 14 & 8. \\
\hline & $2-1$ & 55. & 10.52 & 0.2585 & 4.0 & 15.0 & 7. & 7. & & 11. \\
\hline & $2-1$ & 61. & 10.5 & 0.2595 & 8. & 10.7 & 1. & 28. & & 16. \\
\hline & $2-1$ & 78. & 10.7 & 0.2637 & 1. & 14.2 & 4. & & 17 & 11. \\
\hline & $2-1$ & 91. & 10.89 & 0.2684 & 2. & 21.1 & 4. & 15 & 15 & 10. \\
\hline & $2-1$ & 106. & 11.03 & 0 . & 2. & 9. & & 18. & 2 & 13. \\
\hline 60 & $2-1$ & 121.0 & 11.18 & 805 & 3.0 & 12.2 & 2 . & 21 . & 19. & 13. \\
\hline 607 & $2-1$ & 136.0 & 11.34 & 0.2861 & 4.0 & 13.2 & 1. & 23.5 & 20.3 & 13.6 \\
\hline 607 & $2-2$ & 1.0 & 11.48 & 0.2898 & 6.2 & 13.1 & 1.4 & 13.1 & 20.6 & 14.2 \\
\hline
\end{tabular}


TABLE A2. (continued)

\begin{tabular}{|c|c|c|c|c|c|c|c|c|c|c|}
\hline \multicolumn{3}{|c|}{$\begin{array}{l}\text { DSDP Sample } \\
\text { Identification }\end{array}$} & \multirow[b]{2}{*}{$\begin{array}{c}\text { Composite } \\
\text { Depth, m }\end{array}$} & \multirow[b]{2}{*}{$\begin{array}{l}\text { Age, } \\
\mathrm{Ma}^{*}\end{array}$} & \multirow[b]{2}{*}{$\begin{array}{c}\text { Species } \\
1 \\
\end{array}$} & \multirow[b]{2}{*}{$\begin{array}{c}\text { Species } \\
2 \\
\end{array}$} & \multirow[b]{2}{*}{$\begin{array}{c}\text { Species } \\
3 \\
\end{array}$} & \multirow[b]{2}{*}{$\begin{array}{c}\text { Species } \\
4 \\
\end{array}$} & \multirow[b]{2}{*}{$\begin{array}{l}\text { SSTs, } \\
{ }^{\circ} \mathrm{C}\end{array}$} & \multirow[b]{2}{*}{$\begin{array}{l}\text { SSTw, } \\
{ }^{\circ} \mathrm{C}\end{array}$} \\
\hline Hole & $\begin{array}{l}\text { Core- } \\
\text { section }\end{array}$ & $\begin{array}{c}\text { Depth, } \\
\mathrm{cm}\end{array}$ & & & & & & & & \\
\hline 607 & $2-2$ & 16.0 & 11.63 & 0.2925 & 2.2 & 15.5 & 8.5 & 9.6 & 16.9 & 10.6 \\
\hline & $2-2$ & 31.0 & 11.78 & 0.2951 & 4.4 & 14.6 & 10.2 & 13.5 & & 11.2 \\
\hline 607 & $2-2$ & 53.0 & 12.01 & 0.2998 & 2.5 & 11.3 & 2.6 & 21.1 & & 12.9 \\
\hline 607 & $2-2$ & 61.0 & 12.09 & 0.3019 & 1.1 & 13.5 & 2.2 & 11.3 & & 12.0 \\
\hline 607 & $2-2$ & 78.0 & 12.26 & 0.3064 & 4.1 & 17.4 & 2.2 & 16.5 & & 12.6 \\
\hline 607 & $2-2$ & 91.0 & 12.38 & 0.30 & 4.3 & 8.7 & 2.3 & 18.3 & 21.1 & 14.0 \\
\hline 607 & $2-2$ & 106.0 & 12.53 & 0.313 & 2.8 & 16.0 & 2.8 & 16.5 & & 12.1 \\
\hline 607 & $2-2$ & 121.0 & 12.68 & 0.3187 & 2.1 & 19.5 & 1.7 & 9.6 & & 11.4 \\
\hline 607 & $2-2$ & 128.0 & 12.76 & 0.3209 & 2.0 & 18.9 & 5.1 & 9.5 & & 10.7 \\
\hline 607 & $2-2$ & 136.0 & 12.84 & 0.3235 & 2.2 & 8.0 & 2.5 & 21.4 & & 13.4 \\
\hline 607 & $2-3$ & 1.0 & 12.98 & 0.3276 & 10.5 & 8.4 & 1.7 & 19.6 & & 16.4 \\
\hline 607 & $2-3$ & 16.0 & 13.13 & 0.3301 & 10.0 & 10.4 & 5.2 & 20.4 & & 15.2 \\
\hline & $2-3$ & 31.0 & 13.28 & 0.3324 & 3.0 & 16.9 & 13.9 & 8.6 & & 9.6 \\
\hline 607 & $2-3$ & 53.0 & 13.51 & 0.3360 & 1.4 & 30.9 & 20.7 & 7.9 & 11.7 & 5.4 \\
\hline 607 & $2-3$ & 61.0 & 13.59 & 0.3374 & 1.2 & 8.3 & 4.7 & 22.4 & 19.9 & 12.3 \\
\hline 607 & $2-3$ & 78.0 & 13.76 & 0.3397 & 1.6 & 23.5 & 8.7 & 9.1 & 14.3 & 8.7 \\
\hline 607 & $2-3$ & 91.0 & 13.88 & 0.3414 & 1.2 & 10.8 & 4.8 & 15.2 & 18.5 & 11.8 \\
\hline 607 & $2-3$ & 106.0 & 14.03 & 0.3440 & 1.1 & 13.9 & 10.1 & 8.2 & 16 & 10.2 \\
\hline 607 & $2-3$ & 121.0 & 14.18 & 0.3472 & 0.7 & 32.2 & 7.3 & 5. & & 7.0 \\
\hline 607 & $2-3$ & 136.0 & 14.34 & 0.3506 & 0.0 & 39.9 & 16.1 & 0. & & 4.1 \\
\hline 607 & $2-4$ & 1.0 & 14.48 & 0.3541 & 0.4 & 15.4 & 9.4 & 5. & & 9.9 \\
\hline 607 & $2-4$ & $16 . c$ & 14.63 & 0.3577 & 1.3 & 19.9 & 5.0 & 9. & & 10.2 \\
\hline 607 & $2-4$ & 23. & 14. & 0.3593 & 2.1 & 22. & 4.2 & & & 10.2 \\
\hline 607 & $2-4$ & 31. & & 0.36 & 2.4 & 1 & 5.9 & 11. & & 11.5 \\
\hline 60 & $2-4$ & 39. & & 0.36 & 2.3 & 1 & 9.2 & & & 10.8 \\
\hline 60 & $2-4$ & 53. & & 0.36 & 3. & & & & & 12.3 \\
\hline 607 & $2-4$ & 61. & & 0.36 & 3.9 & 10.2 & 3. & & & 13.3 \\
\hline 607 & $2-4$ & 78. & & 0.37 & 2.2 & 10.3 & 9. & 16 & & 11.2 \\
\hline 607 & $2-4$ & 91.0 & & 0.37 & 5.7 & 7.9 & 3.9 & 22.1 & & 14.4 \\
\hline 607 & $2-4$ & 106.0 & 53 & 0.38 & 2.8 & 9.9 & 1.2 & 18.5 & & 13.6 \\
\hline 607 & $2-4$ & 121.0 & 68 & 0.38 & 2.6 & 14.5 & 1.5 & 17.5 & & 12.6 \\
\hline 607 & $2-4$ & 136.0 & 15.84 & 0.39 & 2.4 & 11.6 & 10.4 & 19.0 & & 10.8 \\
\hline 607 & $2-5$ & 1.0 & 15.98 & 0.39 & 5.1 & 6.6 & 1.1 & 39.6 & 25.5 & 16.9 \\
\hline 607 & -5 & 16.0 & 16.14 & 0.3993 & 5.6 & 12.6 & 2.7 & 32.9 & 22.6 & 15.2 \\
\hline 607 & -5 & 23.0 & 16.20 & 0.4007 & 11.7 & 10.6 & 4.2 & 29.9 & & 17.1 \\
\hline 607 & -5 & 31.0 & 16.28 & 0.4022 & 12.5 & 7.7 & 0.3 & 27.9 & & 18.3 \\
\hline 607 & -5 & 53.0 & 0 & 0.4061 & 22.2 & 8. & 0.6 & 24.2 & & 20.2 \\
\hline 07 & -5 & 61.0 & 16.5 & $0.40^{\circ}$ & 16.6 & 6.7 & 1.1 & 25. & & .1 \\
\hline 607 & -5 & 68. & 1 & 0.40 & .6 & 8.9 & 1.4 & 21. & & \\
\hline & & 78. & & 0.41 & & 8.3 & 1.0 & 22.1 & & .7 \\
\hline & & 10 & & 0.41 & & 7.2 & 0.6 & 15.3 & & .5 \\
\hline 60 & & 106.0 & & 0.41 & & 18.7 & 0.4 & 18.3 & & 18.9 \\
\hline 607 & -5 & 121.0 & 17.18 & 0.42 & 11.9 & 21.1 & 1.4 & 24.2 & & 16.7 \\
\hline 607 & -5 & 136.0 & 17.33 & 0.42 & 6.5 & 10.7 & 14.3 & 20.2 & & 11.8 \\
\hline 607 & -5 & 143.0 & 17.40 & 0.42 & 1.0 & 7.3 & 49.7 & 4.9 & & 5.8 \\
\hline 607 & -6 & 16.0 & 17.64 & 0.43 & 1.9 & 19.0 & 10.3 & 28.7 & & 9.8 \\
\hline & & 23.0 & 17.7 & 0.43 & 1.8 & 19.6 & 7.8 & 11.1 & & 9.7 \\
\hline 60 & & 31.0 & 17.7 & 0.43 & 1. & & 18.4 & 17.1 & & 8.4 \\
\hline & & 40. & & 0.43 & & & .7 & 9. & & 6.3 \\
\hline & & 53. & & 0.43 & & & 8 & 5. & & 5.6 \\
\hline & & & & & & & 4 & 8. & & 6. \\
\hline & & 68. & & & & & 3 & 9.6 & & 6.3 \\
\hline & & & 18.2 & 0.44 & 1.1 & & 13.4 & 19.6 & 14.2 & 8.1 \\
\hline $60^{\circ}$ & & 91.0 & 18.39 & 4447 & 1.1 & 13.4 & 6.7 & 28.6 & 18.4 & 11.2 \\
\hline 60 & & 106.0 & 18.53 & & 2.1 & 10.1 & 5.1 & 20.3 & 19.4 & 12.3 \\
\hline $60^{\circ}$ & $2-6$ & 121.0 & 18.68 & & 2.3 & 15.6 & 9.9 & 11.4 & 16.6 & 10.3 \\
\hline 607 & $2-6$ & 136.0 & 18.83 & 0.4526 & 0.8 & 14.3 & 19.2 & 12.0 & 14.6 & 8.2 \\
\hline
\end{tabular}


TABLE A2. (continued)

\begin{tabular}{|c|c|c|c|c|c|c|c|c|c|c|}
\hline \multicolumn{3}{|c|}{$\begin{array}{l}\text { DSDP Sample } \\
\text { Identification }\end{array}$} & \multirow[b]{2}{*}{$\begin{array}{c}\text { Composite } \\
\text { Depth, m }\end{array}$} & \multirow[b]{2}{*}{$\begin{array}{l}\text { Age, } \\
\mathrm{Ma}^{*}\end{array}$} & \multirow[b]{2}{*}{$\begin{array}{c}\text { Species } \\
1 \\
\end{array}$} & \multirow[b]{2}{*}{$\begin{array}{c}\text { Species } \\
2 \\
\end{array}$} & \multirow[b]{2}{*}{$\begin{array}{c}\text { Species } \\
3 \\
\end{array}$} & \multirow[b]{2}{*}{$\begin{array}{c}\text { Species } \\
4 \\
\end{array}$} & \multirow[b]{2}{*}{$\begin{array}{c}\text { SSTs, } \\
{ }^{\circ} \mathrm{C} \\
\end{array}$} & \multirow[b]{2}{*}{$\begin{array}{c}\text { SSTw, } \\
{ }^{\circ} \mathrm{C} \\
\end{array}$} \\
\hline Hole & $\begin{array}{l}\text { Core- } \\
\text { section }\end{array}$ & $\begin{array}{c}\text { Depth, } \\
\mathrm{cm}\end{array}$ & & & & & & & & \\
\hline 607 & $2-7$ & 1.0 & 18.98 & 0.4546 & 2.2 & 14.3 & 6.9 & 25.1 & 18.3 & 11.3 \\
\hline 607 & $2-7$ & 16.0 & 19.14 & & 1.2 & 15.1 & 12.9 & 12.2 & 15.7 & \\
\hline 607 & $2-7$ & 24.0 & 19.22 & 0.4576 & 0.0 & 19.0 & 4.8 & 11.2 & 15.2 & 9.8 \\
\hline 607 & $3-2$ & 91.0 & 19.34 & 0.4612 & 3.1 & 8.7 & 13.0 & 12.4 & 18.3 & 11.1 \\
\hline 607 & $3-2$ & 106.0 & 19.49 & 0.4676 & 0.7 & 8.1 & 16.1 & 16.5 & 17.2 & 9.6 \\
\hline 607 & $3-2$ & 119.0 & 19.63 & 0.4723 & 6.3 & 10.5 & 8.6 & 8.2 & 19.7 & 12.8 \\
\hline 607 & $3-2$ & 121.0 & 19.65 & 0.4726 & 2.5 & 10.2 & 4.9 & 13.0 & 19.2 & 12.4 \\
\hline 607 & $3-2$ & 136.0 & 19.80 & 0.4747 & 4.1 & 9.0 & 4.5 & 23.2 & 21.0 & 13.5 \\
\hline 607 & $3-3$ & 1.0 & 19.94 & 0.4768 & 3.3 & 12.7 & 2.0 & 17.1 & 19.5 & 13.1 \\
\hline 607 & $3-3$ & 16.0 & 20.09 & 0.4807 & 6.8 & 8.6 & 1.1 & 18.4 & 22.3 & 15.2 \\
\hline 607 & $3-3$ & 31.0 & 20.24 & 0.4880 & 3.5 & 10.6 & 1.6 & 16.3 & 20.2 & 13.6 \\
\hline 607 & $3-3$ & 53.0 & 20.47 & 0.5017 & 5.0 & 14.4 & 2.7 & 12.1 & 19.5 & 13.2 \\
\hline 607 & $3-3$ & 61.0 & 20.55 & 0.5075 & 4.9 & 16.2 & 9.2 & 13.7 & 17.8 & 11.3 \\
\hline 607 & $3-3$ & 68.0 & 20.61 & 0.5121 & 1.4 & 13.8 & 19.7 & 15.2 & 14.9 & 8.4 \\
\hline 607 & $3-3$ & 78.0 & 20.72 & 0.5180 & 2.5 & 8.7 & 9.4 & 23.9 & 19.7 & 11.6 \\
\hline 607 & $3-3$ & 91.0 & 20.84 & 0.5277 & 4.0 & 14.4 & 1. 4 & 21.6 & 19.8 & 13.4 \\
\hline 607 & $3-3$ & 106.0 & 20.99 & 0.5411 & 4.2 & 10.0 & 3.3 & 20.3 & 20.7 & 13.6 \\
\hline 607 & $3-3$ & 121.0 & 21.15 & 0.5521 & 2.4 & 8.8 & 2.1 & 25.5 & 21.0 & 13.6 \\
\hline 607 & $3-3$ & 128.0 & 21.22 & 0.5578 & 2.2 & 13.6 & 4.0 & 17.9 & 18.4 & 12.0 \\
\hline 607 & $3-3$ & 136.0 & 21.30 & 0.56 & 0.7 & 13.2 & 3.7 & 20.7 & 18.0 & 11.5 \\
\hline 607 & $3-4$ & 1.0 & 21.44 & 0.57 & 3.5 & 9.6 & 5.4 & 22.1 & 20.3 & 12.9 \\
\hline 607 & $3-4$ & 16.0 & 21.5 & 0.57 & 3.3 & 11.6 & 3.3 & 13. & 19.4 & 12.9 \\
\hline 607 & $3-4$ & 31.0 & 21.74 & 0.58 & 7. & 13.2 & & 12.8 & & 13.4 \\
\hline 60 & $3-4$ & 42.0 & 21.85 & 0.58 & 5.8 & 9.6 & 12.9 & 8.3 & 18.8 & 12.0 \\
\hline 60 & $3-4$ & 53.0 & 21.97 & 0.58 & 7.7 & 17.7 & 12.6 & 16.1 & 18.3 & 11.7 \\
\hline 60 & $3-4$ & 61.0 & 22.05 & 0.5862 & 2.8 & 14.2 & 4. 5 & 14.2 & 18.3 & 11.9 \\
\hline $60^{\circ}$ & $3-4$ & 69.0 & 22.13 & 0.5887 & 7.6 & 12.6 & 2.7 & 13.6 & 21.1 & 14.4 \\
\hline 607 & $3-4$ & 78.0 & 22.22 & 0.5914 & 4.5 & 12.0 & 3.4 & 12.4 & 19.8 & 13.2 \\
\hline 607 & $3-4$ & 91.0 & 22.34 & 0.5939 & 8.9 & 18.5 & 0.6 & 9.2 & 20.8 & 14.5 \\
\hline 607 & $4-1$ & 43.0 & 22.45 & 0.5988 & 4.5 & 9.6 & 1.6 & 14.1 & 20.8 & 14.0 \\
\hline 607 & $4-1$ & 53.0 & 22.55 & 0.6034 & 7.5 & 13.5 & 0.0 & 8.6 & 21.1 & 14.8 \\
\hline 607 & $4-1$ & 61.0 & 22.63 & 0.6074 & 4.6 & 9.9 & 1.3 & 10.2 & 20.6 & 14.1 \\
\hline 607 & $4-1$ & 70.0 & 22.72 & 0.6093 & 5.2 & 14.7 & 1.4 & 10.1 & 19.6 & 13.5 \\
\hline 607 & $4-1$ & 78. & 22.80 & 0.6103 & 6.7 & 10.9 & 1.2 & 11.9 & 21.3 & 14.6 \\
\hline 607 & $4-1$ & 91.0 & 22.93 & 0.6119 & 9.7 & 13.4 & 0.9 & 4.0 & 21.9 & 15.3 \\
\hline 607 & $4-1$ & 98.0 & 23.00 & 0.6128 & 11.3 & 12.7 & 1.3 & 9.0 & 22. & \\
\hline 607 & $4-1$ & 106.0 & 3.08 & 0.6137 & 12.1 & 12.1 & 1.2 & 9.0 & 22.9 & 16.1 \\
\hline 607 & $4-1$ & 111.0 & 23.13 & 0.6143 & 12.4 & 13.6 & 2.9 & 9.1 & 22.5 & 15.6 \\
\hline 607 & $4-1$ & 121.0 & 23.23 & 0.6155 & 8.9 & 11.0 & 4.2 & 10.1 & 21.4 & 14.6 \\
\hline 607 & $4-1$ & 136.0 & 23.38 & 0.6163 & 9.9 & 13.2 & 3.6 & 11.2 & 21.5 & 14.8 \\
\hline 607 & $4-2$ & 1.0 & 23.53 & 0.6172 & 12.5 & 12.5 & 5.9 & 12.5 & 22.0 & 15.1 \\
\hline 607 & $4-2$ & 16.0 & 23.68 & 0.6180 & 9.8 & 17.5 & 5.8 & 12.7 & 20.5 & 13.8 \\
\hline 607 & $4-2$ & 23.0 & 23.75 & 0.6184 & 11.6 & 13.5 & 7.6 & 15.3 & 21.3 & 14.5 \\
\hline 607 & $4-2$ & 31.0 & 23.83 & 0.6188 & 8.3 & 14.2 & 10.5 & 12.5 & 19.3 & 12.6 \\
\hline 607 & $4-2$ & 42.0 & 23.94 & 0.6195 & 11.4 & 13.9 & 5.7 & 13.0 & 21.6 & 14.7 \\
\hline 607 & $4-2$ & 53.0 & 24.05 & 0.6201 & 9.7 & 13.0 & 8.8 & 12.7 & 20.4 & 13.6 \\
\hline 607 & $4-2$ & 61.0 & 24.13 & 207 & 7. & 15.1 & 9.2 & 11.0 & 19.3 & 12.6 \\
\hline 607 & $4-2$ & 78.0 & 24.30 & 521 & 5. & 14.4 & 10.1 & 13.6 & 18.3 & 11.6 \\
\hline 607 & $4-2$ & 91.0 & 24.43 & 0.6229 & 4. & 11.9 & 18.2 & 10.8 & 16.9 & 10.5 \\
\hline 607 & $4-2$ & 106.0 & 24.58 & 0.6242 & 2.3 & 14.1 & 11.5 & 16.9 & 16.9 & 10.2 \\
\hline 607 & $4-2$ & 121.0 & 24.73 & 0.6254 & 1.8 & 17.1 & 20.0 & 24.7 & 14.8 & 7.9 \\
\hline 607 & $4-2$ & 136.0 & 24.88 & 0.6267 & 3.7 & 15.9 & 3.4 & 30.2 & 19.9 & 13.3 \\
\hline 607 & $4-3$ & 1. 0 & 25.03 & 0.6293 & 0.7 & 15.2 & 2.8 & 31.1 & 18.4 & 12.1 \\
\hline 607 & $4-3$ & 16.0 & 25.18 & 0.6320 & 3.3 & 18.5 & 2.7 & 35.8 & 19.8 & 14.1 \\
\hline 607 & $4-3$ & 31.0 & 25.33 & 6346 & 1.9 & 14.7 & 4.5 & 30.9 & 19.1 & 12.3 \\
\hline 607 & $4-3$ & 53.0 & 25.55 & 0.6445 & 1.1 & 21.0 & 5.5 & 16.9 & 15.1 & 9.7 \\
\hline 607 & $4-3$ & 61.0 & 25.63 & 0.6476 & 2.1 & 13.9 & 7.8 & 20.2 & 17.7 & 10.9 \\
\hline
\end{tabular}


TABLE A2. (continued)

\begin{tabular}{|c|c|c|c|c|c|c|c|c|c|c|}
\hline \multicolumn{3}{|c|}{$\begin{array}{l}\text { DSDP Sample } \\
\text { Identification }\end{array}$} & \multirow[b]{2}{*}{$\begin{array}{l}\text { Composite } \\
\text { Depth, m }\end{array}$} & \multirow[b]{2}{*}{$\begin{array}{l}\text { Age, } \\
\mathrm{Ma}^{*}\end{array}$} & \multirow[b]{2}{*}{$\begin{array}{c}\text { Species } \\
1\end{array}$} & \multirow[b]{2}{*}{$\begin{array}{c}\text { Species } \\
2 \\
\end{array}$} & \multirow[b]{2}{*}{$\begin{array}{c}\text { Species } \\
3\end{array}$} & \multirow[b]{2}{*}{$\begin{array}{c}\text { Species } \\
4\end{array}$} & \multirow[b]{2}{*}{$\begin{array}{l}\text { SSTs, } \\
{ }^{\circ} \mathrm{C} \\
\end{array}$} & \multirow[b]{2}{*}{$\begin{array}{c}\text { SSTw, } \\
{ }^{\circ} \mathrm{C} \\
\end{array}$} \\
\hline Hole & $\begin{array}{l}\text { Core- } \\
\text { section }\end{array}$ & $\begin{array}{c}\text { Depth, } \\
\mathrm{cm}\end{array}$ & & & & & & & & \\
\hline 607 & $4-3$ & 78.0 & 25.80 & 0.6517 & 1.0 & 16.7 & 6.2 & 27.9 & 17.1 & 10.7 \\
\hline 607 & $4-3$ & 91.0 & 25.93 & 0.6543 & 1.3 & 12.9 & 4.8 & 40.2 & 20.8 & 13.4 \\
\hline 607 & $4-3$ & 106.0 & 26.08 & 0.6573 & 2.4 & 20.0 & 4.8 & 29.0 & 17.3 & 11.5 \\
\hline 607 & $4-3$ & 121.0 & 26.23 & 0.6603 & 4.7 & 20.5 & 2.5 & 25.2 & 18.6 & 12.9 \\
\hline 607 & $4-3$ & 136.0 & 26.38 & 0.6633 & 2.7 & 14.2 & 7.5 & 20.7 & 18.0 & 11.2 \\
\hline 607 & $4-4$ & 1.0 & 26.53 & 0.6663 & 4.3 & 6.4 & 9.8 & 21.3 & 20.6 & 12.5 \\
\hline 607 & $4-4$ & 16.0 & 26.68 & 0.6691 & 1.5 & 7.5 & 12.3 & 16.4 & 18.5 & 10.8 \\
\hline 607 & $4-$ & 31.0 & 26.83 & 0.671 & 1.8 & 7.5 & 12.6 & 12.9 & 18.3 & 10.9 \\
\hline 607 & $4-4$ & 53.0 & 27.05 & 0.6750 & 2.2 & 18.2 & 16.0 & 21.2 & 15.0 & 8.5 \\
\hline 607 & $4-4$ & 61.0 & 27.13 & 0.6758 & 2.2 & 9.3 & 28.5 & 16.1 & 14.4 & 8.2 \\
\hline 607 & $4-4$ & 78.0 & 27.30 & 0.6774 & 3.6 & 13.0 & 15.1 & 17.2 & 17.0 & 10.2 \\
\hline 607 & $4-4$ & 91.0 & 27.43 & 0.6788 & 4.8 & 16.1 & 10.6 & 11.9 & 17.5 & 11.0 \\
\hline 607 & $4-4$ & 106.0 & 27.58 & 0.6805 & 3.3 & 8.1 & 19.5 & 7.2 & 17.1 & 10.3 \\
\hline 607 & $4-4$ & 121.0 & 27.73 & 0.6824 & 4.9 & 17.9 & 8.5 & 13.5 & 17.6 & 11.2 \\
\hline 607 & $4-4$ & 136.0 & 27.88 & 0.6844 & 11.7 & 17.5 & 0.4 & 23.0 & 23.6 & 16.8 \\
\hline 607 & $4-5$ & 1.0 & 28.03 & 0.6864 & 17.5 & 11.7 & 4.4 & 13.9 & 23.6 & 16.9 \\
\hline 607 & $4-5$ & 16.0 & 28.18 & 0.6884 & 14.9 & 11.7 & 0.0 & 19.2 & 24.8 & 18.0 \\
\hline 607 & $4-5$ & 31.0 & 28.33 & 0.6900 & 11.1 & 16.9 & 2.0 & 16.9 & 22.2 & 15.5 \\
\hline 607 & $4-5$ & 42.0 & 28.44 & 0.6911 & 20.4 & 11.8 & 1.1 & 10.5 & .2 & 18.2 \\
\hline 607 & $4-5$ & 53.0 & 28.55 & 0.6921 & 17.2 & 12.8 & 0.9 & 10 & 24 & 17.5 \\
\hline 607 & $4-5$ & 61.0 & 28.63 & 0.6928 & 15.1 & 11.1 & 2.7 & 17 & 24.0 & 17.1 \\
\hline 607 & $4-5$ & 78.0 & 28.8 & 0.6946 & 5.3 & 14.7 & 37.9 & 12.6 & 12.5 & 8.0 \\
\hline 607 & $4-5$ & 91.0 & 28.93 & 0.69 & 0.0 & 4.7 & 72.4 & 11.5 & 6.7 & 0.4 \\
\hline 607 & $4-5$ & 106.0 & 29.08 & 0.6982 & 2.3 & 7.4 & 26.1 & 27.6 & 16.5 & 8.0 \\
\hline 607 & $4-5$ & 121.0 & 29.23 & 0.7002 & 0.9 & 8.9 & 27.0 & 21.7 & .8 & 7.5 \\
\hline 607 & $4-5$ & 136.0 & 29.38 & 0.7021 & 2.2 & 9.5 & 12.0 & 29.5 & 19.5 & 10.9 \\
\hline 607 & $4-6$ & 1. 0 & 29.53 & 0.7039 & 1.4 & 9.8 & 10.3 & 24.6 & 18.7 & 10.8 \\
\hline 607 & $4-6$ & 16.0 & 29.68 & 0.7058 & 2.4 & 15.6 & 4.6 & 18.7 & 17.8 & 11.6 \\
\hline 607 & $4-6$ & 31.0 & 29.83 & 0.7078 & 4.3 & 18.1 & 5.7 & 8.2 & 17.7 & 11.6 \\
\hline 607 & $4-6$ & 53.0 & 30.05 & 0.7108 & 8.3 & 13.3 & 4.1 & 12.7 & 20.9 & 14.1 \\
\hline 607 & $4-6$ & 61.0 & 30.13 & 0.7118 & 4.1 & 13.5 & 3.8 & 16.2 & & 12.8 \\
\hline 607 & $4-6$ & 78.0 & 30.30 & 0.71 & 4.2 & 15.2 & 14.2 & & & 10.3 \\
\hline 607 & $4-6$ & 91.0 & 3 & & 2.6 & 9.6 & 10.7 & 20.2 & & 11.2 \\
\hline 607 & $4-6$ & 106. & 30.58 & 0.7170 & 2.5 & 14.4 & 19.5 & 14.4 & & 8.9 \\
\hline 607 & -6 & 121.0 & 30.73 & 0.7183 & 0.3 & 6.8 & 10.5 & 18.3 & 18 & 10.8 \\
\hline 60 & $4-6$ & 136.0 & 30.88 & 0.7195 & 0.6 & 13.5 & 7.4 & 26.4 & 17.7 & 10.6 \\
\hline & -7 & 1.0 & 1.03 & 0.7209 & 1.5 & 7.9 & 6.2 & 16.4 & .4 & 12.1 \\
\hline 607 & -7 & 16.0 & .18 & 0.7226 & 3.1 & 9.3 & 11.1 & 34.9 & 21.1 & 12.0 \\
\hline & $4-7$ & 24.0 & 1.26 & 0.7236 & 3.4 & 16.7 & 8.2 & 23.4 & 17 & 11.1 \\
\hline $607 \mathrm{~A}$ & $5-4$ & 121.0 & 1.42 & 0.7254 & 3.4 & 15.0 & 6.1 & 16.0 & 18.1 & 11.6 \\
\hline $607 \mathrm{~A}$ & $5-4$ & 135.0 & 1.56 & 0.7270 & 9.4 & 14.3 & 4.3 & 23.7 & 22.2 & 15.1 \\
\hline $607 A$ & & 1.0 & 1.72 & 0.7289 & 3.3 & 12.3 & 2.7 & 26.2 & 20.4 & 13.4 \\
\hline $607 A$ & $5-5$ & 15.0 & 31.86 & 0.7330 & 12.4 & 9.7 & 2.7 & 22.1 & 24.0 & 16.8 \\
\hline $607 \mathrm{~A}$ & $5-5$ & 30.0 & 32.01 & 0.7374 & 7.8 & 15.3 & 25.1 & 9.7 & 15.7 & 10.5 \\
\hline $607 \mathrm{~A}$ & & 45.0 & 32.16 & 0.7429 & 1.3 & 11.9 & 54.3 & 8.8 & 9.1 & 4.1 \\
\hline $607 \mathrm{~A}$ & 5 & 61.0 & 32.32 & 0.7488 & 1.6 & 7.2 & 15.3 & 31.6 & 19.7 & 10.2 \\
\hline $607 \mathrm{~A}$ & & 75.0 & 32.46 & 0.7512 & 2.2 & 10.6 & 11.7 & 16.0 & 17.8 & 10.7 \\
\hline 607 & $5-1$ & 16.0 & 32.62 & 0.7538 & 1.5 & 13.6 & 12.1 & 22.4 & 16.9 & 9.8 \\
\hline 607 & $5-1$ & 22.0 & 32.68 & 0.7545 & 2.4 & 24.4 & 11.7 & 16.2 & 14.1 & 8.2 \\
\hline 607 & $5-1$ & 31.0 & 32.77 & 0.7556 & 2.5 & 13.2 & 5.1 & 12.4 & 18.3 & 11.9 \\
\hline 607 & $5-1$ & 53.0 & 32.99 & 0.7581 & 5.7 & 10.9 & 12.0 & 20.3 & .2 & 12.0 \\
\hline 607 & $5-1$ & 61.0 & 33.07 & 0.7590 & 3.4 & 16.7 & 17.3 & 16.1 & 15 & 9.2 \\
\hline 607 & $5-1$ & 78.0 & 33.24 & 0.7609 & 3 & 12.0 & 4.3 & 27.7 & 20.3 & 13.1 \\
\hline 607 & $5-1$ & 93.0 & 33.39 & 0.7627 & 3.8 & 9.5 & 21.0 & 12.1 & 16.5 & 10.0 \\
\hline 607 & $5-1$ & 106.0 & & 0.7649 & 5.9 & 10.2 & 13.8 & 11.5 & 18.6 & 11.7 \\
\hline 607 & $5-1$ & 119.0 & 33.65 & 0.7679 & 7.1 & 14.9 & 7.5 & 18.8 & 19.8 & 12.9 \\
\hline 607 & $5-1$ & 136.0 & 33.82 & 0.7719 & 5.8 & 16.0 & 6.1 & 14.1 & 18.9 & 12.4 \\
\hline 607 & $5-2$ & 1.0 & 33.97 & 0.7755 & 7.0 & 13.3 & 11.1 & 9.2 & 18.9 & 12.2 \\
\hline
\end{tabular}


TABLE A2. (continued)

\begin{tabular}{|c|c|c|c|c|c|c|c|c|c|c|}
\hline \multicolumn{3}{|c|}{$\begin{array}{l}\text { DSDP Sample } \\
\text { Identification }\end{array}$} & \multirow[b]{2}{*}{$\begin{array}{c}\text { Composite } \\
\text { Depth, m }\end{array}$} & \multirow[b]{2}{*}{$\begin{array}{l}\text { Age, } \\
\mathrm{Ma}^{*}\end{array}$} & \multirow[b]{2}{*}{$\begin{array}{c}\text { Species } \\
1 \\
\end{array}$} & \multirow[b]{2}{*}{$\begin{array}{c}\text { Species } \\
2 \\
\end{array}$} & \multirow[b]{2}{*}{$\begin{array}{c}\text { Species } \\
3 \\
\end{array}$} & \multirow[b]{2}{*}{$\begin{array}{c}\text { Species } \\
4\end{array}$} & \multirow[b]{2}{*}{$\begin{array}{l}\text { SSTs, } \\
{ }^{\circ} \mathrm{C} \\
\end{array}$} & \multirow[b]{2}{*}{$\begin{array}{c}\text { SSTw, } \\
{ }^{\circ} \mathrm{C} \\
\end{array}$} \\
\hline Hole & $\begin{array}{l}\text { Core- } \\
\text { section }\end{array}$ & $\begin{array}{c}\text { Depth, } \\
\mathrm{cm}\end{array}$ & & & & & & & & \\
\hline 607 & $5-2$ & 16.0 & 34.12 & 0.7789 & 4.4 & 14.5 & 11.6 & 11.3 & 17.5 & 10.9 \\
\hline 607 & $5-2$ & 31.0 & 34.27 & 0.7820 & 11.2 & 8.4 & 3.7 & 15.9 & 23.0 & 15.9 \\
\hline 607 & $5-2$ & 37.0 & 34.33 & 0.7831 & 13.0 & 10.9 & 8.3 & 14.2 & 21.6 & 14.9 \\
\hline 607 & $5-2$ & 46.0 & 34.42 & 0.7848 & 8.5 & 8.8 & 24.4 & 7.9 & 16.5 & 11.3 \\
\hline 607 & $5-2$ & 53.0 & 34.49 & 0.7862 & 4.0 & 12.6 & 35.6 & 9.8 & 12.7 & 8.2 \\
\hline 607 & $5-2$ & 61.0 & 34.57 & 0.7878 & 0.4 & 3.3 & 75.9 & 3.3 & 7.1 & 1.3 \\
\hline 607 & $5-2$ & 78.0 & 34.74 & 0.7912 & 1.5 & 5.5 & 49.1 & 16.8 & 10.1 & 4. 2 \\
\hline 607 & $5-2$ & 91.0 & 34.87 & 0.7938 & 0.3 & 4.1 & 50.7 & 19.5 & 9.7 & 3.0 \\
\hline 607 & $5-2$ & 107.0 & 35.03 & 0.7965 & 0.4 & 10.8 & 39.2 & 16.2 & 11.1 & 5.6 \\
\hline 607 & $5-2$ & 121.0 & 35.17 & 0.7988 & 1.8 & 11.6 & 45.1 & 9.4 & 10.5 & 6.0 \\
\hline 607 & $5-2$ & 136.0 & 35.32 & 0.8012 & 0.6 & 5.4 & 59.5 & 11.4 & 8.3 & 2.7 \\
\hline 607 & $5-3$ & 1.0 & 35.47 & 0.8035 & 0.0 & 4.8 & 82.9 & 0.6 & 6.8 & 0.9 \\
\hline 607 & $5-3$ & 18.0 & 35.64 & 0.8061 & 0.6 & 4.0 & 60.3 & 12.9 & 8.2 & 2.3 \\
\hline 607 & $5-3$ & 31.0 & 35.77 & 0.8080 & 0.7 & 6.8 & 30.0 & 19.8 & 14.4 & 7.3 \\
\hline 607 & $5-3$ & 37.0 & 35.83 & 0.8087 & 2.2 & 6.2 & 23.7 & 15.3 & 16.4 & 9.2 \\
\hline 607 & $5-3$ & 53.0 & 35.99 & 0.8106 & 1.6 & 8.8 & 4.5 & 14.6 & 19.4 & 12.4 \\
\hline 607 & $5-3$ & 61.0 & 36.07 & 0.8116 & 2.2 & 9.9 & 8.7 & 20.4 & 18.9 & 11.4 \\
\hline 607 & $5-3$ & 78.0 & 36.24 & 0.8142 & 2.2 & 8.7 & 9.9 & 19.2 & 19.0 & 11.3 \\
\hline 607 & $5-3$ & 93.0 & 36.39 & 0.8166 & 2.6 & 7.1 & 19.4 & 9.7 & 17.2 & 10.1 \\
\hline 607 & $5-3$ & 106.0 & 36.52 & 0.8187 & 1.9 & 9.6 & 6.4 & 9.2 & 18.8 & 12.0 \\
\hline 607 & $5-3$ & 121.0 & 36.67 & 0.8227 & 5.2 & 11.9 & 13.3 & 14.1 & 18.1 & 11.3 \\
\hline 607 & $5-3$ & 136.0 & 36.82 & 0.8290 & 1.9 & 6.9 & 49.1 & 7.2 & 10.4 & 5.9 \\
\hline 607 & $5-3$ & 143.0 & 36.89 & 0.8320 & 0.0 & 4.9 & 61.9 & 8.1 & 8.1 & 2.7 \\
\hline 607 & $5-4$ & 1. 0 & 36.97 & 0.8352 & 0.0 & 1.7 & 44.9 & 21.1 & 11.7 & 4.2 \\
\hline 607 & $5-4$ & 9.0 & 37.05 & 0.8368 & 0.0 & 3.4 & 28.4 & 19.8 & 15.8 & 7.6 \\
\hline 607 & $5-4$ & 16.0 & 37.12 & 0.8382 & 0.6 & 7.0 & 31.9 & 13.1 & 13.8 & 7.5 \\
\hline 607 & $5-4$ & 31.0 & 37.27 & 0.8412 & 3.6 & 6.4 & 21.0 & 20.2 & 17.5 & 10.0 \\
\hline 607 & $5-4$ & 37.0 & 37.33 & 0.8424 & 3.0 & 10.1 & 39.8 & 16.9 & 11.7 & 6.5 \\
\hline 607 & $5-4$ & 46.0 & 37.42 & 0.8435 & 4.2 & 16.6 & 29.0 & 10.3 & 13.7 & 8.6 \\
\hline 607 & $5-4$ & 53.0 & 37.49 & 0.8443 & 3.8 & 8.2 & 38.6 & 11.4 & 12.4 & 7.8 \\
\hline 607 & $5-4$ & 59.0 & 37.55 & 0.8450 & 6.3 & 8.9 & 30.0 & 15.1 & 14.6 & 9.6 \\
\hline 607 & $5-4$ & 68.0 & 37.64 & 0.8461 & 3.3 & 10.3 & 20.0 & 13.6 & 16.4 & 9.8 \\
\hline 607 & $5-4$ & 73.0 & 37.69 & 0.8467 & 5.3 & 19.8 & 17.2 & 11.2 & 15.9 & 9.6 \\
\hline 607 & $5-4$ & 78.0 & 37.74 & 0.8473 & 4.7 & 10.3 & 10.0 & 15.3 & 19.1 & 12.0 \\
\hline 607 & $5-4$ & 91.0 & 37.87 & 0.8489 & 2.5 & 8.8 & 17.5 & 16.6 & 17.3 & 10.0 \\
\hline 607 & $5-4$ & 106.0 & 38.02 & 0.8507 & 7.8 & 6.6 & 3.6 & 17.7 & 22.5 & 15.1 \\
\hline 607 & $5-4$ & 121.0 & 38.17 & 0.8525 & 7.6 & 10.9 & 1.8 & 12.0 & 21.5 & 14.8 \\
\hline 607 & $5-4$ & 131.0 & 38.27 & 0.8537 & 6.1 & 11.6 & 2.6 & 19.0 & 21.1 & 14.2 \\
\hline 607 & $5-5$ & 3.0 & 38.49 & 0.8570 & 12.3 & 14.1 & 4.6 & 16.3 & 22.3 & 15.4 \\
\hline 607 & $5-5$ & 16.0 & 38.62 & 0.8615 & 13.1 & 11.4 & 7.3 & 15.2 & 22.0 & 15.2 \\
\hline 607 & $5-5$ & 29.0 & 38.75 & 0.8671 & 8.6 & 22.4 & 23.4 & 14.5 & 17.1 & 10.4 \\
\hline 607 & $5-5$ & 37.0 & 38.83 & 0.8705 & 2.5 & 19.9 & 28.4 & 4.3 & 13.1 & 7.6 \\
\hline 607 & $5-5$ & 46.0 & 38.92 & 0.8717 & 3.8 & 9.0 & 28.3 & 14.7 & 14.7 & 9.0 \\
\hline 607 & $5-5$ & 53.0 & 38.99 & 0.8727 & 0.9 & 9.1 & 38.4 & 8.4 & 12.0 & 7.0 \\
\hline 607 & $5-5$ & 61.0 & 39.07 & 0.8738 & 7.8 & 16.7 & 3.7 & 10.7 & 20.0 & 13.6 \\
\hline 607 & $5-5$ & 78.0 & 39.24 & 0.8762 & 1.8 & 13.1 & 3.5 & 14.9 & 18.3 & 12.0 \\
\hline 607 & $5-5$ & 91.0 & 39.37 & 0.8781 & 5.4 & 14.0 & 6.0 & 18.7 & 19.5 & 12.7 \\
\hline 607 & $5-5$ & 106.0 & 39.52 & 0.8802 & 5.2 & 12.6 & 4.8 & 11.3 & 19.6 & 13.0 \\
\hline 607 & $5-5$ & 119.0 & 39.65 & 0.8828 & 2.3 & 13.8 & 16.4 & 6.4 & 16.0 & 9.6 \\
\hline 607 & $5-5$ & 127.0 & 39.73 & 0.8851 & 6.1 & 11.2 & 15.1 & 12.5 & 18.1 & 11.4 \\
\hline 607 & $5-5$ & 136.0 & 39.82 & 0.8876 & 1.8 & 10.7 & 22.7 & 8.7 & 15.3 & 8.9 \\
\hline 607 & $5-6$ & 1.0 & 39.97 & 0.8924 & 3.3 & 3.3 & 13.9 & 16.2 & 19.9 & 11.7 \\
\hline 607 & $5-6$ & 16.0 & 40.12 & 0.8967 & 2.6 & 6.7 & 5.4 & 26.6 & 21.4 & 13.1 \\
\hline 607 & $5-6$ & 31.0 & 40.27 & 0.9013 & 5.9 & 9.4 & 3.8 & 15.7 & 21.1 & 14.0 \\
\hline 607 & $5-6$ & 36.0 & 40.32 & 0.9029 & 5.5 & 11.0 & 5.8 & 15.0 & 20.1 & 13.1 \\
\hline 607 & $5-6$ & 53.0 & 40.49 & 0.9092 & 2.9 & 13.1 & 8.7 & 20.2 & 18.2 & 11.2 \\
\hline 607 & $5-6$ & 61.0 & 40.57 & 0.9126 & 3.9 & 10.5 & 25.8 & 5.8 & 15.3 & 9.5 \\
\hline
\end{tabular}


TABLE A2. (continued)

\begin{tabular}{|c|c|c|c|c|c|c|c|c|c|c|}
\hline \multicolumn{3}{|c|}{$\begin{array}{l}\text { DSDP Sample } \\
\text { Identification }\end{array}$} & \multirow[b]{2}{*}{$\begin{array}{c}\text { Composite } \\
\text { Depth, m }\end{array}$} & \multirow[b]{2}{*}{$\begin{array}{l}\text { Age, } \\
\mathrm{Ma}^{*}\end{array}$} & \multirow[b]{2}{*}{$\begin{array}{c}\text { Species } \\
1\end{array}$} & \multirow[b]{2}{*}{$\begin{array}{c}\text { Species } \\
2\end{array}$} & \multirow[b]{2}{*}{$\begin{array}{c}\text { Species } \\
3\end{array}$} & \multirow[b]{2}{*}{$\begin{array}{c}\text { Species } \\
4\end{array}$} & \multirow[b]{2}{*}{$\begin{array}{c}\text { SSTs, } \\
{ }^{\circ} \mathrm{C} \\
\end{array}$} & \multirow[b]{2}{*}{$\begin{array}{c}\text { SSTw, } \\
{ }^{\circ} \mathrm{C}\end{array}$} \\
\hline Hole & $\begin{array}{l}\text { Core- } \\
\text { section }\end{array}$ & $\begin{array}{c}\text { Depth, } \\
\mathrm{cm}\end{array}$ & & & & & & & & \\
\hline 607 & $5-6$ & 78.0 & 40.74 & 0.9198 & 1.4 & 8.1 & 50.7 & 5.5 & 10.1 & 5.6 \\
\hline 607 & $5-6$ & 88.0 & 40.84 & 0.9237 & 6.0 & 9.1 & 34.9 & 11.0 & 13.4 & 9.1 \\
\hline 607 & $5-6$ & 106.0 & 41.02 & 0.9301 & 6.3 & 8.5 & 28.8 & 11.0 & 15.0 & 10.0 \\
\hline 607 & $5-6$ & 121.0 & 41.17 & 0.9354 & 5.5 & 6.1 & 39.9 & 11.7 & 12.4 & 8.2 \\
\hline 607 & $5-6$ & 136.0 & 41.32 & 0.9406 & 8.5 & 11.8 & 9.9 & 18.7 & 20.3 & 13.3 \\
\hline 607 & $5-7$ & 1.0 & 41.47 & 0.9457 & 5.8 & 8.8 & 18.8 & 15.4 & 17.7 & 11.0 \\
\hline 607 & $5-7$ & 16.0 & 41.62 & 0.9505 & 12.3 & 8.3 & 4.3 & 17.4 & 23.2 & 16.1 \\
\hline 607 & $5-7$ & 21.0 & 41.67 & 0.9520 & 13.8 & 12.4 & 3.2 & 12.9 & 23.1 & 16.2 \\
\hline $607 \mathrm{~A}$ & $6-4$ & 121.0 & 41.83 & 0.9552 & 9.5 & 17.3 & 7.1 & 14.8 & 20.3 & 13.5 \\
\hline $607 \mathrm{~A}$ & $6-4$ & 135.0 & 41.97 & 0.9568 & 8.4 & 10.6 & 6.8 & 17.9 & 21.1 & 14.0 \\
\hline $607 \mathrm{~A}$ & $6-5$ & 1.0 & 42.13 & 0.9585 & 5.9 & 11.1 & 16.5 & 11.3 & 17.7 & 11.2 \\
\hline $607 \mathrm{~A}$ & $6-5$ & 15.0 & 42.26 & 0.9601 & 3.8 & 15.6 & 3.5 & 6.8 & 18.4 & 12.4 \\
\hline $607 \mathrm{~A}$ & $6-5$ & 21.0 & 42.33 & 0.9607 & 6.4 & 14.7 & 3.0 & 10.4 & 19.9 & 13.5 \\
\hline $607 \mathrm{~A}$ & $6-5$ & 31.0 & 42.42 & 0.9618 & 6.4 & 12.6 & 5.3 & 10.8 & 20.0 & 13.3 \\
\hline $607 \mathrm{~A}$ & $6-5$ & 45.0 & 42.56 & 0.9634 & 4.0 & 11.0 & 4.3 & 19.9 & 20.1 & 13.1 \\
\hline $607 \mathrm{~A}$ & $6-5$ & 61.0 & 42.72 & 0.9653 & 3.4 & 11.6 & 6.4 & 19.5 & 19.2 & 12.2 \\
\hline $607 \mathrm{~A}$ & $6-5$ & 75.0 & 42.86 & 0.9670 & 3.6 & 12.9 & 22.5 & 15.6 & 15.3 & 9.2 \\
\hline $607 \mathrm{~A}$ & $6-5$ & 91.0 & 43.02 & 0.9688 & 3.6 & 10.0 & 32.5 & 14.3 & 13.5 & 8.3 \\
\hline 607 & $6-1$ & 16.0 & 43.17 & 0.9705 & 4.4 & 10.3 & 36.3 & 10.6 & 12.8 & 8.4 \\
\hline 607 & $6-1$ & 31.0 & 43.32 & 0.9722 & 3.1 & 14.5 & 29.0 & 13.4 & 13.4 & 8.1 \\
\hline 607 & $6-1$ & 53.0 & 43.54 & 0.9747 & 3.3 & 11.2 & 32.0 & 8.2 & 13.6 & 8.6 \\
\hline 607 & $6-1$ & 61.0 & 43.62 & 0.9756 & 1.5 & 12.5 & 4.9 & 6.1 & 18.0 & 11.8 \\
\hline 607 & $6-1$ & 70.0 & 43.71 & 0.9766 & 14.1 & 10.6 & 0.5 & 22.3 & 25.0 & 18.0 \\
\hline 607 & $6-1$ & 78.0 & 43.79 & 0.9777 & 9.6 & 13.3 & 1.1 & 14.8 & 22.1 & 15.4 \\
\hline 607 & $6-1$ & 91.0 & 43.92 & 0.9813 & 17.7 & 4.8 & 2.3 & 12.9 & 24.7 & 17.9 \\
\hline 607 & $6-1$ & 106.0 & 44.07 & 0.9855 & 21.4 & 7.4 & 0.0 & 14.4 & & 19.2 \\
\hline 607 & $6-1$ & 121.0 & 44.22 & 0.9896 & 22.3 & 5.0 & 1.7 & 9.0 & 25.1 & 18.7 \\
\hline 607 & $6-1$ & 136.0 & 44.37 & 0.9937 & 20.8 & 8.1 & 0.0 & 7.8 & 25.5 & 18.7 \\
\hline 607 & $6-2$ & 1. 0 & 44.52 & 0.9979 & 22.9 & 9.1 & 3.1 & 18.6 & 24.8 & 18.6 \\
\hline 607 & $6-2$ & 16.0 & 44.67 & 1.0020 & 14.5 & 16.5 & 1.2 & 17.3 & 24.0 & 17.0 \\
\hline 607 & $6-2$ & 31.0 & 44.82 & 1.0067 & 10.3 & 10.3 & 16.1 & 19.7 & 19.2 & 12.8 \\
\hline 607 & $6-2$ & 39.0 & 44.90 & 1.0090 & 8.5 & 17.3 & 26.6 & 14.6 & 15.7 & 10.4 \\
\hline 607 & $6-2$ & 53.0 & 45.04 & 1.0159 & 5.6 & 9.4 & 4.9 & 22.3 & 21.3 & 13.9 \\
\hline 607 & $6-2$ & 61.0 & 45.12 & 1.0180 & 6.8 & 4.5 & 23.4 & 20.1 & 17.6 & 10.8 \\
\hline 607 & $6-2$ & 78.0 & 45.29 & 1.0224 & 12.1 & 11.8 & 2.4 & 20.5 & 23.5 & 16.5 \\
\hline 607 & $6-2$ & 89.0 & 45.40 & 1.0258 & 12.7 & 12.6 & 6.5 & 10.9 & 21.8 & 15.0 \\
\hline 607 & $6-2$ & 106.0 & 45.57 & 1.0342 & 13.3 & 10.4 & 2.9 & 10.7 & 23.1 & 16.3 \\
\hline 607 & $6-2$ & 121.0 & 45.72 & 1.0386 & 7.1 & 10.2 & 8.1 & 18.3 & 20.6 & 13.4 \\
\hline 607 & $6-2$ & 136.0 & 45.87 & 1.0430 & 4.0 & 11.2 & 24.5 & 14.9 & 15.3 & 9.3 \\
\hline 607 & $6-3$ & 1.0 & 46.02 & 1.0474 & 1.9 & 5.3 & 9.7 & 30.5 & 21.4 & 12.0 \\
\hline 607 & $6-3$ & 4.0 & 46.05 & 1.0479 & 4.7 & 6.8 & 9.4 & 28.8 & 21.7 & 13.0 \\
\hline 607 & $6-3$ & 8.0 & 46.09 & 1.0485 & 3.4 & 6.8 & 11.5 & 28.3 & 20.7 & 11.9 \\
\hline 607 & $6-3$ & 16.0 & 46.17 & 1.0495 & 2.5 & 5.5 & 16.8 & 23.4 & 19.0 & 10.4 \\
\hline 607 & $6-3$ & 23.0 & 46.24 & 1.0504 & 5.2 & 9.5 & 23.6 & 25 . & 17.1 & 9.6 \\
\hline 607 & $6-3$ & 31.0 & 46.32 & 1.0514 & 2.9 & 5.2 & 39.8 & 14. & 12.4 & 7.1 \\
\hline 607 & -3 & 40.0 & 46.41 & 1.0526 & 6.3 & 10.1 & 20.6 & 18. & 17.2 & 10.7 \\
\hline 607 & -3 & 53.0 & 46.54 & 1.0543 & 4.7 & 9.4 & 20.3 & 15.2 & 16.9 & 10.3 \\
\hline 607 & -3 & 63.0 & 46.64 & 1.0556 & 9.5 & 8.4 & 10.2 & 31.9 & 23.3 & 14.8 \\
\hline 607 & -3 & 78.0 & 46.79 & 1.0575 & 8.5 & 7.7 & 10.7 & 15.6 & 20.6 & 13.5 \\
\hline 607 & $6-3$ & 91.0 & 46.92 & 1.0592 & 11.6 & 6.8 & 7.1 & 15.3 & 22.3 & 15.2 \\
\hline 607 & $6-3$ & 101.0 & 47.02 & 1.0603 & 13.6 & 11.6 & 7.9 & 8.3 & 21.7 & 15.0 \\
\hline 607 & $6-3$ & 103.0 & 47.04 & 1.0606 & 16.6 & 12.8 & 7.3 & 6.2 & 22.5 & 15.7 \\
\hline 607 & $6-3$ & 106.0 & 47.07 & 1.0609 & 14.2 & 9.1 & 4.7 & 10.7 & 23.0 & 16.1 \\
\hline 607 & $6-3$ & 121.0 & 47.22 & 1.0627 & 11.7 & 11.4 & 3.9 & 8.8 & 22.3 & 15.4 \\
\hline 607 & $6-3$ & 129.0 & 47.30 & 1.0636 & 18.3 & 14.3 & 2.7 & 9.1 & 24.3 & 17.1 \\
\hline 607 & $6-3$ & 136.0 & 47.37 & 1.0644 & 12.8 & 14.1 & 4.2 & 11.2 & 22.3 & 15.4 \\
\hline 607 & $6-4$ & 1.0 & 47.52 & 1.0663 & 18.4 & 10.2 & 3.0 & 6.3 & 24.2 & 17.3 \\
\hline
\end{tabular}


TABLE A2. (continued)

\begin{tabular}{|c|c|c|c|c|c|c|c|c|c|c|}
\hline \multicolumn{3}{|c|}{$\begin{array}{l}\text { DSDP Sample } \\
\text { Identification } \\
\end{array}$} & \multirow[b]{2}{*}{$\begin{array}{c}\text { Composite } \\
\text { Depth, m }\end{array}$} & \multirow[b]{2}{*}{$\begin{array}{l}\text { Age, } \\
\mathrm{Ma}^{*}\end{array}$} & \multirow[b]{2}{*}{$\begin{array}{c}\text { Species } \\
1 \\
\end{array}$} & \multirow[b]{2}{*}{$\begin{array}{c}\text { Species } \\
2 \\
\end{array}$} & \multirow[b]{2}{*}{$\begin{array}{c}\text { Species } \\
3 \\
\end{array}$} & \multirow[b]{2}{*}{$\begin{array}{c}\text { Species } \\
4 \\
\end{array}$} & \multirow[b]{2}{*}{$\begin{array}{c}\text { SSTs, } \\
{ }^{\circ} \mathrm{C}\end{array}$} & \multirow[b]{2}{*}{$\begin{array}{c}\text { SSTw, } \\
{ }^{\circ} \mathrm{C} \\
\end{array}$} \\
\hline Hole & $\begin{array}{l}\text { Core- } \\
\text { section }\end{array}$ & $\begin{array}{c}\text { Depth, } \\
\mathrm{cm}\end{array}$ & & & & & & & & \\
\hline 607 & $6-4$ & 16.0 & 47.67 & 1.0679 & 15.5 & 14.5 & 0.3 & 13.2 & 24.2 & 17.3 \\
\hline 607 & $6-4$ & 29.0 & 47.80 & 1.0696 & 11.3 & 14.1 & 10.8 & 17.2 & 20.5 & 13.8 \\
\hline 607 & $6-4$ & 40.0 & 47.91 & 1.0717 & 20.1 & 15.0 & 0.8 & 2.8 & 25.4 & 17.8 \\
\hline 607 & $6-4$ & 53.0 & 48.04 & 1.0744 & 9.1 & 17.8 & 2.2 & 14.1 & 20.9 & 14.4 \\
\hline 607 & $6-4$ & 61.0 & 48.12 & 1.0761 & 17.1 & 11.6 & 2.6 & 10.7 & 24.0 & 17.1 \\
\hline 607 & $6-4$ & 78.0 & 48.29 & 1.0788 & 15.4 & 15.1 & 0.6 & 6.8 & 23.9 & 16.8 \\
\hline 607 & $6-4$ & 91.0 & 48.42 & 1.0801 & 14.4 & 10.8 & 4.9 & 4.2 & 22.8 & 15.9 \\
\hline 607 & $6-4$ & 95.0 & 48.46 & 1.0806 & 14.9 & 13.3 & 6.5 & 4.9 & 22.4 & 15.4 \\
\hline 607 & $6-4$ & 106.0 & 48.57 & 1.0817 & 6.4 & 7.3 & 14.9 & 4.7 & 19.1 & 12.2 \\
\hline 607 & $6-4$ & 121.0 & 48.72 & 1.0833 & 5.9 & 6.8 & 7.4 & 13.9 & 20.9 & 13.5 \\
\hline 607 & $6-4$ & 136.0 & 48.87 & 1.0849 & 6.0 & 5.3 & 10.3 & 12.6 & 20.6 & 13.1 \\
\hline 607 & $6-5$ & 1.0 & 49.02 & 1.0881 & 5.5 & 3.4 & 7.9 & 7.6 & 21.2 & 13.7 \\
\hline 607 & $6-5$ & 8.0 & 49.09 & 1.0897 & 4.2 & 7.7 & 4.5 & 26.8 & 21.9 & 13.9 \\
\hline 607 & $6-5$ & 16.0 & 49.17 & 1.0914 & 8.0 & 8.7 & 3.1 & 13.9 & 22.0 & 14.9 \\
\hline 607 & $6-5$ & 18.0 & 49.19 & 1.0916 & 8.9 & 8.6 & 5.1 & 16.8 & 22.0 & 14.8 \\
\hline 607 & $6-5$ & 31.0 & 49.32 & 1.0933 & 5.9 & 6.7 & 2.6 & 23.4 & 22.8 & 15.0 \\
\hline 607 & $6-5$ & 38.0 & 49.39 & 1.0942 & 10.3 & 10.7 & 0.7 & 10.3 & 22.7 & 15.9 \\
\hline 607 & $6-5$ & 53.0 & 49.54 & 1.0964 & 13.5 & 5.3 & 2.3 & 22.0 & 24.9 & 17.5 \\
\hline 607 & $6-5$ & 60.0 & 49.61 & 1.0974 & 11.8 & 8.9 & 1.0 & 23.6 & 24.6 & 17.3 \\
\hline 607 & $6-5$ & 61.0 & 49.62 & 1.0976 & 13.7 & 4.3 & 2.2 & 20.5 & 25.0 & 17.5 \\
\hline 607 & $6-5$ & 78.0 & 49.79 & 1.1002 & 8.4 & 7.2 & 0.0 & 16.4 & 23.2 & 16.1 \\
\hline 607 & $6-5$ & 91.0 & 49.92 & 1.1022 & 7.2 & 7.6 & 2.0 & 16.1 & 22.3 & 15.2 \\
\hline 607 & $6-5$ & 106.0 & 50.07 & 1.1045 & 22.1 & 13.1 & 0.0 & 23.2 & 27.4 & 20.4 \\
\hline 607 & $6-5$ & 121.0 & 50.22 & 1.1068 & 14.8 & 11.7 & 0.8 & 19.1 & 24.6 & 17.7 \\
\hline 607 & $6-5$ & 136.0 & 50.37 & 1.1099 & 18.7 & 14.0 & 0.3 & 15.7 & 25.4 & 18.4 \\
\hline 607 & $6-6$ & 1.0 & 50.52 & 1.1145 & 10.2 & 10.2 & 0.7 & 21.1 & 23.6 & 16.5 \\
\hline 607 & $6-6$ & 16.0 & 50.67 & 1.1192 & 7.0 & 10.4 & 1.2 & 19.5 & 22.0 & 15.1 \\
\hline 607 & $6-6$ & 31.0 & 50.82 & 1.1238 & 5.6 & 4.0 & 1.6 & 26.7 & 24.0 & 15.7 \\
\hline 607 & $6-6$ & 38.0 & 50.89 & 1.1260 & 8.5 & 9.7 & 0.3 & 13 & 22.5 & 15.7 \\
\hline 607 & $6-6$ & 53.0 & 51.04 & 1.1305 & 0.9 & 7.2 & 1.2 & 16.2 & 20.2 & 13.3 \\
\hline 607 & $6-6$ & 61.0 & 51.12 & 1.1327 & 1.4 & 2.8 & 0.0 & & 23.6 & 15.0 \\
\hline 607 & $6-6$ & 70.0 & 51.21 & 1.1348 & 3.5 & 8.9 & 0.7 & 16.1 & 20.8 & 14.1 \\
\hline 607 & $6-6$ & 78.0 & 51.29 & 1.13 & 5.8 & 7.2 & 0.3 & 18.6 & 22.4 & 15.3 \\
\hline 607 & $6-6$ & 91.0 & 51.42 & 1.1397 & 6.5 & 6.2 & 4.9 & 15.4 & 21.8 & 14.4 \\
\hline 607 & $6-6$ & 106.0 & 51.57 & 1.1432 & 16.9 & 7.1 & 0.3 & 15.4 & 25.2 & 18.3 \\
\hline 607 & $6-6$ & 119.0 & 51.70 & 1.1462 & 10.6 & 8.8 & 0.3 & 27.3 & 25.0 & 17.6 \\
\hline 607 & -6 & 136.0 & 51.87 & 1.1499 & 21.8 & 16.1 & 0.4 & 18.8 & 27.0 & 19.5 \\
\hline 607 & $6-7$ & 1.0 & 52.02 & 1.1531 & 15.3 & 11.7 & 0.3 & 17.3 & 24.7 & 17.8 \\
\hline 607 & $6-7$ & 9.0 & 52.10 & 1.1548 & 14.2 & 11.9 & 1.6 & 29.0 & 26.0 & 18.6 \\
\hline $607 \mathrm{~A}$ & $7-5$ & 1.0 & 52.25 & 1.1582 & 12.4 & 14.2 & 0.7 & 27.0 & 24.8 & 17.8 \\
\hline $607 \mathrm{~A}$ & $7-5$ & 15.0 & 52.40 & 1.1632 & 11.2 & 7.0 & 1.0 & 25.1 & 25.0 & 17.4 \\
\hline $607 A$ & $7-5$ & 30.0 & 52.54 & 1.1705 & 9.2 & 9.2 & 0.0 & 27.7 & 24.5 & 17.1 \\
\hline $607 \mathrm{~A}$ & $7-5$ & 41.0 & 52.65 & 1.1748 & 3.3 & 14.0 & 0.7 & 26.0 & 20.1 & 13.7 \\
\hline $607 \mathrm{~A}$ & $7-5$ & 45.0 & 52.69 & 1.1755 & 5.8 & 11.6 & 0.0 & 24.3 & 22.0 & 15.2 \\
\hline $607 A$ & $7-5$ & 60.0 & 52.84 & 1.1782 & 1. 4 & 19.1 & 0.8 & 16.3 & 16.6 & .5 \\
\hline 607 & $7-1$ & 16.0 & 52.99 & 1.1809 & 10.0 & 10.3 & 0.7 & 18.9 & 23.3 & 16.3 \\
\hline 607 & $7-1$ & 29.0 & 53.13 & 1.1832 & 7.5 & 14.2 & 1.1 & 28.1 & 22.5 & .7 \\
\hline 607 & $7-1$ & 37.0 & 53.20 & 1.1845 & 12.6 & 12.1 & 0.0 & 22.7 & 24.5 & 17.6 \\
\hline 607 & $7-1$ & 53.0 & 53.36 & 1.1870 & 15.6 & 10.1 & 0.0 & 16.7 & 24.9 & 18.0 \\
\hline 607 & $7-1$ & 61.0 & 53.44 & 1.1881 & 15.6 & 12.6 & 1.7 & 11.6 & 23.9 & 17.0 \\
\hline 607 & $7-1$ & 78.0 & 53.61 & 1.1905 & 12.7 & 11.3 & 0.0 & 8.0 & 23.4 & 16.7 \\
\hline 607 & $7-1$ & 91.0 & 53.74 & 1.1924 & 5.7 & 13.0 & 0.4 & 24.0 & 21.5 & 14.9 \\
\hline 607 & $7-1$ & 106.0 & 53.90 & 1.1945 & 7.0 & 13.4 & 0.0 & 24.3 & 22.1 & 15.5 \\
\hline 607 & $7-1$ & 121.0 & 54.04 & 1.1969 & 6.5 & 16.4 & 0.3 & 15.0 & 20.2 & 14.1 \\
\hline 607 & $7-1$ & 136.0 & 54.19 & 1.2004 & 7.3 & 10.1 & 0.6 & 19.0 & 22.3 & 15.4 \\
\hline 607 & $7-2$ & 1.0 & 4.34 & 1.2039 & 10.2 & 10.2 & 1.2 & 0.3 & 22.5 & 15.7 \\
\hline 607 & $7-2$ & 16.0 & 54.49 & 1.2077 & 2.5 & 10.1 & 1.2 & 28.7 & 21.2 & 13.9 \\
\hline
\end{tabular}


TABLE A2. (continued)

\begin{tabular}{|c|c|c|c|c|c|c|c|c|c|c|}
\hline \multicolumn{3}{|c|}{$\begin{array}{l}\text { DSDP Sample } \\
\text { Identification }\end{array}$} & \multirow[b]{2}{*}{$\begin{array}{c}\text { Composite } \\
\text { Depth, m }\end{array}$} & \multirow[b]{2}{*}{$\begin{array}{l}\text { Age, } \\
\mathrm{Ma}^{*}\end{array}$} & \multirow[b]{2}{*}{$\begin{array}{c}\text { Species } \\
1 \\
\end{array}$} & \multirow[b]{2}{*}{$\begin{array}{c}\text { Species } \\
2 \\
\end{array}$} & \multirow[b]{2}{*}{$\begin{array}{c}\text { Species } \\
3 \\
\end{array}$} & \multirow[b]{2}{*}{$\begin{array}{c}\text { Species } \\
4 \\
\end{array}$} & \multirow[b]{2}{*}{$\begin{array}{l}\text { SSTs, } \\
{ }^{\circ} \mathrm{C}\end{array}$} & \multirow[b]{2}{*}{$\begin{array}{c}\text { SSTw, } \\
{ }^{\circ} \mathrm{C}\end{array}$} \\
\hline Hole & $\begin{array}{l}\text { Core- } \\
\text { section }\end{array}$ & $\begin{array}{c}\text { Depth, } \\
\mathrm{cm}\end{array}$ & & & & & & & & \\
\hline 607 & $7-2$ & 24.0 & 54.57 & 1.2102 & 2.7 & 12.2 & 1.0 & 25.8 & 20.3 & 13.6 \\
\hline 607 & $7-2$ & 31.0 & 54.65 & 1.2124 & 5.0 & 9.2 & 0.4 & 38.3 & 24.5 & 16.8 \\
\hline 607 & $7-2$ & 37.0 & 54.70 & 1.2148 & 6.4 & 11.6 & 1.5 & 27.1 & 22.4 & 15.3 \\
\hline 607 & $7-2$ & 53.0 & 54.86 & 1. 2212 & 19.4 & 7.7 & 0.7 & 14.3 & 25.3 & 18.6 \\
\hline 607 & $7-2$ & 63.0 & 54.97 & 1.2248 & 16.4 & 9.4 & 1.0 & 14.0 & 24.6 & 17.8 \\
\hline 607 & $7-2$ & 78.0 & 55.11 & 1.2292 & 13.1 & 10.5 & 1.3 & 15.6 & 23.7 & 16.8 \\
\hline 607 & $7-2$ & 91.0 & 55.24 & 1.2329 & 18.3 & 8.3 & 0.7 & 14.6 & 25.2 & 18.4 \\
\hline 607 & $7-2$ & 106.0 & 55.40 & 1.2373 & 19.8 & 10.7 & 1.5 & 9.9 & 24.9 & 18.0 \\
\hline 607 & $7-2$ & 121.0 & 55.54 & 1.2397 & 6.7 & 8.1 & 1.4 & 31.6 & 24.2 & 16.2 \\
\hline 607 & $7-2$ & 136.0 & 55.69 & 1.2421 & 7.8 & 15.0 & 0.6 & 13.8 & 21.0 & 14.7 \\
\hline 607 & $7-3$ & 1.0 & 55.84 & 1.2445 & 4.9 & 12.7 & 3.6 & 11.6 & 19.7 & 13.2 \\
\hline 607 & $7-3$ & 16.0 & 55.99 & 1.2468 & 8.2 & 10.5 & 5.1 & 15.2 & 21.3 & 14.3 \\
\hline 607 & $7-3$ & 29.0 & 56.13 & 1.2489 & 2.7 & 7.8 & 12.2 & 17.2 & 18.8 & 11.2 \\
\hline 607 & $7-3$ & 37.0 & 56.20 & 1.2507 & 3.6 & 7.7 & 13.1 & 14.2 & 18.8 & 11.4 \\
\hline 607 & $7-3$ & 53.0 & 56.36 & 1.2543 & 6.1 & 4.0 & 20.2 & 9.8 & 18.4 & 11.5 \\
\hline 607 & $7-3$ & 63.0 & 56.47 & 1.2571 & 3.7 & 7.1 & 18.3 & 19.5 & 18.1 & 10.5 \\
\hline 607 & $7-3$ & 78.0 & 56.61 & 1.2612 & 4.5 & 8.6 & 16.3 & 21.1 & .5 & 10.9 \\
\hline 607 & $7-3$ & 91.0 & 56.74 & 1.2648 & 2.7 & 6.5 & 0.4 & 22.1 & 21.7 & 14.4 \\
\hline 607 & $7-3$ & 106.0 & 56.90 & 1.2689 & 7.1 & 14.7 & 0.9 & 18.7 & 21.0 & 14.6 \\
\hline 607 & $7-3$ & 121.0 & 57.04 & 1.2730 & 10.2 & 19.0 & 0.3 & 11.2 & 21.5 & 15.0 \\
\hline 607 & $7-3$ & 136.0 & 57.19 & 1.2772 & 6.9 & 12.9 & 1.4 & 23.8 & 21.8 & 15.0 \\
\hline 607 & $7-4$ & 1.0 & 57.34 & 1.2815 & 10.6 & 12.3 & 1.4 & 12.3 & 22.5 & 15.7 \\
\hline 607 & $7-4$ & 16.0 & 57.49 & 1.2857 & 6.8 & 12.8 & 4.1 & 19.6 & 20.9 & 14.0 \\
\hline 607 & $7-4$ & 29.0 & 57.63 & 1.2894 & 6.2 & 13.1 & 9.9 & 9.1 & 18.9 & 12.2 \\
\hline 607 & 7- & 37.0 & 57.70 & 1.2916 & 1.6 & 12.3 & 16.8 & 8.5 & & 9.4 \\
\hline 607 & $7-4$ & 53.0 & 57.86 & 1.2958 & 7.1 & 11.8 & 14.5 & 16.8 & 18.6 & 11.8 \\
\hline 607 & $7-4$ & 59.0 & 57.92 & 1.2975 & 4.6 & 19.7 & 12.4 & 15.9 & 16.4 & 10.0 \\
\hline 607 & $7-4$ & 69.0 & 58.02 & 1.3001 & 5.3 & 15.2 & 5.3 & 28.8 & 20.5 & 13.5 \\
\hline 607 & $7-4$ & 78.0 & 58.11 & 1.3024 & 8.7 & 14.5 & 5.5 & 20.4 & 21.1 & 14.1 \\
\hline 607 & $7-4$ & 91.0 & 58.24 & 1.3058 & 4.7 & 8.3 & 0.7 & 16.0 & 21.4 & 14.6 \\
\hline 607 & $7-4$ & 100.0 & 58.33 & 1.3082 & 11.0 & 15.2 & 3.1 & 21.4 & 22.7 & 15.7 \\
\hline 607 & $7-4$ & 106.0 & 58.40 & 1.3097 & 10.0 & 15.2 & 1.6 & 14.8 & 21.9 & 15.2 \\
\hline 607 & $7-4$ & 121.0 & 58.54 & 1.3135 & 12.6 & 12.0 & 0.5 & 16.6 & 23.7 & 16.8 \\
\hline 607 & $7-4$ & 136.0 & 58.69 & 1.3172 & 15.3 & 8.4 & 1.1 & 10.2 & 24.3 & 17.4 \\
\hline 607 & $7-5$ & 1.0 & 58.84 & 1.3213 & 15.6 & 12.0 & 2.7 & 18.3 & 24.1 & 17.2 \\
\hline 607 & $7-5$ & 16.0 & 58.99 & 1.3254 & 4.4 & 11.3 & 11.6 & 20.4 & 18.8 & 11.5 \\
\hline 607 & $7-5$ & 30.0 & 59.13 & 1.3314 & 2.8 & 15.3 & 17.9 & 15.3 & 15.4 & 9.1 \\
\hline 607 & $7-5$ & 37.0 & 59.20 & 1.3355 & 1.1 & 14.2 & 19.5 & 23.8 & 15.2 & 8.0 \\
\hline 607 & $7-5$ & 53.0 & 59.36 & 1.3420 & 3.1 & 8.7 & 9.0 & 31.3 & 21.1 & 12.3 \\
\hline 607 & $7-5$ & 61. & 59.44 & 1.3439 & 3.4 & 7.5 & 9.1 & 27.5 & 20.9 & 12.4 \\
\hline 607 & $7-5$ & 78.0 & 59.61 & 1.3468 & 2.1 & 12.5 & 3.9 & 23 & 19.2 & 12.3 \\
\hline 607 & $7-5$ & 91.0 & 74 & 1.348 & 1.5 & 6. & 3.8 & & 21.0 & 13.1 \\
\hline 607 & $7-5$ & 106.0 & & 1.35 & 8.2 & 12.0 & 1.3 & & 22.9 & 15.8 \\
\hline 607 & $7-5$ & 121.0 & .04 & 1.35 & 14.4 & 15.2 & 1.1 & 17. & 24.0 & 17.0 \\
\hline 607 & $7-5$ & 136.0 & & 1. 3 & 18.8 & 11.4 & 0.0 & 14. & 25.4 & 18.6 \\
\hline 607 & $7-6$ & 1.0 & & 1.3 & 12.2 & 9.3 & 1.4 & 22.9 & 24.4 & 17.2 \\
\hline 607 & $7-6$ & 16.0 & 60.49 & 1.35 & 17.8 & 10.0 & 3.1 & 15.2 & 24.2 & 17.5 \\
\hline 607 & $7-6$ & 31.0 & 60.65 & 1.3616 & 12.5 & 10.3 & 4.5 & 18.6 & 23.0 & 16.0 \\
\hline 607 & $7-6$ & 37.0 & 60.70 & 1.3626 & 2.7 & 9.9 & 16.0 & 19.4 & 17.5 & 10.1 \\
\hline 607 & $7-6$ & 53.0 & 60.86 & 1.3653 & 2.7 & 13.9 & 19.6 & 13.5 & 15.4 & 9.1 \\
\hline 607 & $7-6$ & 61.0 & 60.94 & 1.3667 & 4.4 & 10.9 & 8.0 & 18.5 & 19.5 & 12.3 \\
\hline 607 & $7-6$ & 69.0 & 61.02 & 1.3688 & 6.2 & 9.2 & 9.2 & 27.8 & 21.5 & 13.4 \\
\hline 607 & $7-6$ & 78.0 & 61.11 & 1.3711 & 5.2 & 8.7 & 11.7 & 23.6 & 20.1 & 12.2 \\
\hline 607 & $7-6$ & 91.0 & 61.24 & 1.3756 & 2.0 & 8.2 & 14.1 & 19.7 & 18.2 & 10.4 \\
\hline 607 & $7-6$ & 106.0 & 61.40 & 1.3807 & 4.1 & 11.1 & 19.0 & 22.2 & 17.2 & 10.0 \\
\hline 607 & $7-6$ & 114.0 & 61.47 & 1.3832 & 8.7 & 13.0 & 9.4 & 18.7 & 20.3 & 13.3 \\
\hline 607 & $7-6$ & 121.0 & 61.54 & 1.3852 & 12.2 & 14.1 & 8.0 & 19.2 & 21.7 & 14.8 \\
\hline
\end{tabular}


TABLE A2. (continued)

\begin{tabular}{|c|c|c|c|c|c|c|c|c|c|c|}
\hline \multicolumn{3}{|c|}{$\begin{array}{l}\text { DSDP Sample } \\
\text { Identification } \\
\end{array}$} & \multirow[b]{2}{*}{$\begin{array}{c}\text { Composite } \\
\text { Depth, m }\end{array}$} & \multirow[b]{2}{*}{$\begin{array}{l}\text { Age, } \\
\mathrm{Ma}^{*}\end{array}$} & \multirow[b]{2}{*}{$\begin{array}{c}\text { Species } \\
1 \\
\end{array}$} & \multirow[b]{2}{*}{$\begin{array}{c}\text { Species } \\
2 \\
\end{array}$} & \multirow[b]{2}{*}{$\begin{array}{c}\text { Species } \\
3 \\
\end{array}$} & \multirow[b]{2}{*}{$\begin{array}{c}\text { Species } \\
4 \\
\end{array}$} & \multirow[b]{2}{*}{$\begin{array}{c}\text { SSTs, } \\
{ }^{\circ} \mathrm{C}\end{array}$} & \multirow[b]{2}{*}{$\begin{array}{c}\text { SSTw, } \\
{ }^{\circ} \mathrm{C}\end{array}$} \\
\hline Hole & $\begin{array}{l}\text { Core- } \\
\text { section }\end{array}$ & $\begin{array}{c}\text { Depth, } \\
\mathrm{cm}\end{array}$ & & & & & & & & \\
\hline 607 & $7-6$ & 136.0 & 61.69 & 1.3893 & 15.7 & 12.3 & 1.4 & 17.2 & 24.4 & 17.5 \\
\hline 607 & $7-7$ & 1.0 & 61.84 & 1.3935 & 14.3 & 16.0 & 1. 4 & 13.3 & 23.5 & 16.5 \\
\hline 607 & $7-7$ & 16.0 & 61.99 & 1.3976 & 18.0 & 16.1 & 0.9 & 20.2 & 25.8 & 18.6 \\
\hline 607 & $7-7$ & 24.0 & 62.07 & 1.3998 & 16.6 & 14.5 & 1.1 & 23.1 & 25.6 & 18.6 \\
\hline $607 \mathrm{~A}$ & $8-5$ & 1.0 & 62.23 & 1.4040 & 6.6 & 8.9 & 9.1 & 11.6 & 20.1 & 13.0 \\
\hline 607 & $8-1$ & 5.0 & 62.38 & 1.4078 & 3.1 & 11.3 & 6.8 & 31.3 & 20.6 & 12.7 \\
\hline 607 & $8-1$ & 16.0 & 62.48 & 1.4104 & 2.8 & 8.8 & 7.7 & 30.3 & 21.0 & 12.5 \\
\hline 607 & $8-1$ & 31.0 & 62.63 & 1.4140 & 1.0 & 9.9 & 13.4 & 36.7 & 19.7 & 10.3 \\
\hline 607 & $8-1$ & 38.0 & 62.70 & 1.4157 & 1.7 & 7.9 & 12.7 & 41.1 & 21.7 & 11.6 \\
\hline 607 & $8-1$ & 53.0 & 62.85 & 1.4172 & 1.2 & 11.7 & 12.8 & & 19.2 & 10.4 \\
\hline 607 & $8-1$ & 61.0 & 62.93 & 1.4181 & 3.6 & 8.9 & 13.9 & & 19. & 11.0 \\
\hline 607 & $8-1$ & 78.0 & 63.10 & 1.4199 & 4.1 & 10.8 & 13.2 & & 19 & 11.2 \\
\hline 607 & $8-1$ & 89.0 & 63.22 & 1.42 & 6.9 & 8. & 7. & 33.1 & 23.5 & 14.7 \\
\hline 607 & $8-1$ & 106.0 & 63.38 & 1.4228 & 4.0 & 10.3 & 25. & & 15. & 9.2 \\
\hline 607 & $8-1$ & 113.0 & 63.45 & 1.4235 & 3.3 & 12.1 & 26.9 & 13.8 & 14.4 & 8.7 \\
\hline 607 & $8-1$ & 121.0 & 63.53 & 1.4242 & 4.9 & 8.6 & 8.6 & 13.8 & 19.9 & 12.6 \\
\hline 607 & $8-1$ & 129.0 & 63.61 & 1.4251 & 5.6 & 5.6 & 4.0 & 24.6 & 22.8 & 14.7 \\
\hline 607 & $8-1$ & 136.0 & 63.6 & 1.426 & 5.1 & 10.6 & 4. & 27.0 & 21. & 14.1 \\
\hline 607 & $8-2$ & 3.0 & 63.85 & 1.4281 & 14.6 & 15.7 & 3. & 20.6 & 24 & .9 \\
\hline 607 & $8-2$ & 16.0 & 63.98 & 1.43 & 11.0 & 13.0 & 2. & & 22 & .6 \\
\hline 607 & $8-2$ & 29.0 & 64.11 & 1.4391 & 6.7 & 10.7 & 5. & & & 3.8 \\
\hline 607 & $8-2$ & 38.0 & 64.21 & 1. 4421 & 4.1 & 7. & 7. & 22.6 & & .9 \\
\hline 607 & $8-2$ & 53.0 & 64.35 & $1.44^{\circ}$ & 11.3 & 3.3 & 7. & & & .4 \\
\hline 607 & $8-2$ & 61.0 & 64.43 & 1.4495 & 5.4 & 8.3 & 8.0 & 17.4 & 20 & 3.0 \\
\hline 607 & $8-2$ & 78.0 & 64.60 & 1.4552 & 5.6 & 13.5 & 6.9 & 16.5 & 19 & 12.6 \\
\hline 607 & $8-2$ & 91.0 & 64.74 & 1.4587 & 6.6 & 11.0 & 6.6 & & 20. & 13.3 \\
\hline 607 & $8-2$ & 106.0 & 64.89 & 1.4606 & 6.3 & 7.8 & 8.1 & & 21.4 & .5 \\
\hline 607 & $8-2$ & 119.0 & 65.01 & 1.4615 & 4.8 & 7.5 & 9.2 & 29.0 & 21.6 & 3.0 \\
\hline 607 & $8-2$ & 136.0 & 65.18 & 1.4628 & 9.0 & 4.1 & 8.2 & 23.2 & 22.9 & 14.8 \\
\hline 607 & $8-3$ & 1.0 & 65.33 & 1.4639 & 8.4 & 10.0 & 14.1 & 18.4 & 19.4 & 12.6 \\
\hline 607 & $8-3$ & 16.0 & 65.49 & 1.4654 & 4.0 & 8.3 & 19.9 & 19.9 & 17.4 & 10.1 \\
\hline 607 & $8-3$ & 21.0 & 65.53 & 1.4659 & 3.2 & 8.6 & 15.2 & 21.8 & 18.4 & 10.6 \\
\hline 607 & $8-3$ & 31.0 & 65.64 & 1.4669 & 4.0 & 9.4 & 5.4 & 16.4 & 20.1 & 13.0 \\
\hline 607 & $8-3$ & 38.0 & 65.71 & 1.4677 & 4.4 & 8.2 & 5.1 & 20.8 & 21.0 & 13.5 \\
\hline 607 & $8-3$ & 53.0 & 65.85 & 1.4693 & 8.9 & 9.9 & 2.4 & 13.4 & 22.1 & 15.2 \\
\hline 607 & $8-3$ & 63.0 & 65.96 & 1.4704 & 12.3 & 11.0 & 1. 7 & 11.3 & 23.1 & 16.3 \\
\hline 607 & $8-3$ & 78.0 & 66.10 & 1.4746 & 13.3 & 10.7 & 2.6 & 16.5 & 23.5 & 16.6 \\
\hline 607 & $8-3$ & 89.0 & 66.21 & 1.4778 & 9.9 & 7.4 & 3.4 & 12.3 & 22.6 & 15.5 \\
\hline 607 & $8-3$ & 106.0 & 66.39 & 1.4857 & 11.8 & 5.6 & 2.8 & 22.0 & 24.4 & .9 \\
\hline 607 & $8-3$ & 119. & 66.51 & 1.4917 & 8.1 & 7.1 & 4.2 & 21.8 & 22.8 & .2 \\
\hline 607 & $8-3$ & 136. & 66.68 & 1.4988 & 11.7 & 4.5 & 2.6 & 19. & 24 & .8 \\
\hline 607 & $8-4$ & 1. & 66.83 & 1.5038 & 11.6 & 6. & 3.5 & 14. & 23.3 & 1 \\
\hline $60^{\circ}$ & $8-4$ & 16. & 99 & 1.5088 & 7.9 & 12.9 & 11.4 & 14 & 19 & 5 \\
\hline 607 & $8-4$ & 21. & 67.03 & 1.510 & 6.0 & 13.8 & 18.0 & & & .7 \\
\hline 607 & $8-$ & 31. & 67.14 & 1.51 & 6.8 & 6.8 & 2.7 & & 22 & .1 \\
\hline 607 & $8-4$ & 37. & 67.19 & 1.51 . & 9. & 6.1 & 1. & 22. & 24 & .5 \\
\hline 607 & $8-4$ & 53.0 & 67.35 & 1.51 & 20.6 & 9. & 0.0 & 19. & 26 & 4 \\
\hline 607 & $8-4$ & 61.0 & 67.43 & 1.5196 & 16.1 & 8.9 & 1.1 & 21. & 25 & 4 \\
\hline 607 & $8-4$ & 78.0 & 67.60 & 1.5222 & 14.5 & 8.0 & 2.1 & 17.3 & 24.3 & 3 \\
\hline 607 & $8-4$ & 91.0 & 67.74 & 1.5241 & 9.2 & 7.5 & 2.9 & 11.3 & 22.5 & 4 \\
\hline 607 & $8-4$ & 106.0 & 67.89 & 1.5264 & 10.3 & 8.8 & 11.9 & 16.5 & 20.5 & \\
\hline 607 & $8-4$ & 121.0 & 68.03 & 1.5287 & 9.5 & 8.9 & 3.9 & 20.3 & 22.8 & \\
\hline 607 & $8-4$ & 136.0 & 68.18 & 1.5309 & 9.3 & 6.9 & 1.2 & 19.8 & & \\
\hline 607 & $8-5$ & 1.0 & 68.33 & 1.5338 & 10.5 & 8.6 & 2.8 & 19.8 & 23. & \\
\hline 607 & $8-5$ & 15.0 & 68.49 & 1.5367 & 10.5 & 6.8 & 8.4 & 24.0 & 22 & \\
\hline 607 & $8-5$ & 20.0 & 68.53 & 1.5375 & 8.8 & 4.6 & 17.3 & 24.0 & & \\
\hline 607 & $8-5$ & 31.0 & 68.64 & 1.5398 & 11.2 & 4.1 & 9.5 & 15.6 & 22.1 & 14.8 \\
\hline
\end{tabular}


TABLE A2. (continued)

\begin{tabular}{|c|c|c|c|c|c|c|c|c|c|c|}
\hline \multicolumn{3}{|c|}{$\begin{array}{l}\text { DSDP Sample } \\
\text { Identification }\end{array}$} & \multirow[b]{2}{*}{$\begin{array}{c}\text { Composite } \\
\text { Depth, m }\end{array}$} & \multirow[b]{2}{*}{$\begin{array}{l}\text { Age, } \\
\mathrm{Ma}^{*}\end{array}$} & \multirow[b]{2}{*}{$\begin{array}{c}\text { Species } \\
1\end{array}$} & \multirow[b]{2}{*}{$\begin{array}{c}\text { Species } \\
2 \\
\end{array}$} & \multirow[b]{2}{*}{$\begin{array}{c}\text { Species } \\
3 \\
\end{array}$} & \multirow[b]{2}{*}{$\begin{array}{c}\text { Species } \\
4 \\
\end{array}$} & \multirow[b]{2}{*}{$\begin{array}{c}\text { sSTs, } \\
{ }^{\circ} \mathrm{C}\end{array}$} & \multirow[b]{2}{*}{$\begin{array}{c}\text { SSTw, } \\
{ }^{\circ} \mathrm{C}\end{array}$} \\
\hline Hole & $\begin{array}{l}\text { Core- } \\
\text { section }\end{array}$ & $\begin{array}{c}\text { Depth, } \\
\mathrm{cm}\end{array}$ & & & & & & & & \\
\hline 607 & $8-5$ & 53.0 & 68.85 & 1.5444 & 14.2 & 8.2 & 0.7 & 17.5 & 24.6 & 17.6 \\
\hline 607 & $8-5$ & 61.0 & 68.93 & 1.5461 & 13.7 & 9.7 & 4.3 & 21.3 & 23.7 & 16.7 \\
\hline 607 & $8-5$ & 78.0 & 69.10 & 1.5497 & 10.7 & 11.0 & 1.1 & 23.5 & 23.8 & 16.7 \\
\hline 607 & $8-5$ & 91.0 & 69.24 & 1.5525 & 15.9 & 15.2 & 0.0 & 29.1 & 27.1 & 19.9 \\
\hline 607 & $8-5$ & 106.0 & 69.39 & 1.5560 & 17.0 & 19.5 & 0.4 & 23.8 & 26.7 & 19.2 \\
\hline 607 & $8-5$ & 121.0 & 69.53 & 1.5597 & 13.7 & 12.3 & 1.4 & 21.6 & 24.4 & 17.4 \\
\hline 607 & $8-5$ & 136.0 & 69.68 & 1.5634 & 15.4 & 4.1 & 1.5 & 22.9 & 25.7 & 18.4 \\
\hline 607 & $8-6$ & 1.0 & 69.83 & 1.5671 & 4.9 & 8.5 & 16.1 & 16.1 & 18.3 & 11.1 \\
\hline 607 & $8-6$ & 16.0 & 69.99 & 1.5707 & 9.4 & 8.3 & 14.4 & 16.3 & 19.7 & 13.0 \\
\hline 607 & $8-6$ & 29.0 & 70.11 & 1.5739 & 1.0 & 14.5 & 17.7 & 13.8 & 14.9 & 8.4 \\
\hline 607 & $8-6$ & 37.0 & 70.19 & 1.5756 & 0.9 & 5.9 & 20.1 & 22.0 & 17.5 & 9.1 \\
\hline 607 & $8-6$ & 53.0 & 70.35 & 1.5790 & 6.2 & 9.3 & 14.1 & 20.3 & 19.2 & 11.9 \\
\hline 607 & $8-6$ & 61.0 & 70.43 & 1.5806 & 18.3 & 7.3 & 6.4 & 16.2 & 23.1 & 16.8 \\
\hline 607 & $8-6$ & 78.0 & 70.60 & 1.5874 & 5.4 & 11.7 & 9.5 & 15.6 & 19.1 & 12.2 \\
\hline 607 & $8-6$ & 89.0 & 70.71 & 1.5860 & 10.6 & 8.3 & 13.1 & 19.6 & 20.4 & 13.6 \\
\hline 607 & $8-6$ & 106.0 & 70.89 & 1.5892 & 4.9 & 7.2 & 9.2 & 21.3 & 20.7 & 12.8 \\
\hline 607 & $8-6$ & 121.0 & 71.03 & 1.5921 & 4.8 & 7.9 & 12.0 & 23.4 & 20.1 & 12.0 \\
\hline 607 & $8-6$ & 136.0 & 71.18 & 1.5950 & 6.5 & 10.5 & 7.8 & 13.1 & 20.1 & 13.1 \\
\hline 607 & $8-7$ & 1.0 & 71.33 & 1.5979 & 10.6 & 11.0 & 11.0 & 13.5 & 20.3 & 13.7 \\
\hline 607 & $8-7$ & 5.0 & 71.38 & 1.5987 & 8.7 & 11.6 & 9.4 & 14.2 & 20.2 & 13.4 \\
\hline $607 \mathrm{~A}$ & $9-4$ & 67.0 & 71.46 & 1.6004 & 3.2 & 12.9 & 14.5 & 18.3 & 17.1 & 10.2 \\
\hline $607 \mathrm{~A}$ & $9-4$ & 75.0 & 71.54 & 1.6020 & 5.4 & 13.5 & 24.0 & 13.1 & 15.3 & 9.8 \\
\hline $607 \mathrm{~A}$ & $9-4$ & 91.0 & 71.71 & 1.6051 & 5.2 & 15.1 & 21.2 & 9.3 & 15.8 & 9.9 \\
\hline $607 A$ & $9-4$ & 105.0 & 71.85 & 1.6078 & 7.0 & 12.8 & 14.4 & 17.3 & 18.4 & 11.7 \\
\hline $607 \mathrm{~A}$ & $9-4$ & 121.0 & 72.00 & 1.6108 & 5.0 & 12.6 & 10.7 & 22.6 & 19.1 & 11.8 \\
\hline $607 \mathrm{~A}$ & $9-4$ & 135.0 & 72.14 & 1.6144 & 4.5 & 12.9 & 10.1 & 20.4 & 18.7 & 11.6 \\
\hline $607 \mathrm{~A}$ & $9-5$ & 1.0 & 72.31 & 1.6185 & 5.2 & 19.3 & 8.8 & 11.4 & 17.4 & 11.0 \\
\hline $607 \mathrm{~A}$ & $9-5$ & 15.0 & 72.44 & 1.6223 & 5.2 & 10.5 & 8.3 & 14.9 & 19.6 & 12.6 \\
\hline $607 A$ & $9-5$ & 30.0 & 72.60 & 1.6264 & 6.5 & 10.1 & 6.5 & 20.1 & 20.9 & 13.6 \\
\hline 607 & $9-1$ & 1.0 & 72.71 & 1.6295 & 20.5 & 10.1 & 1.4 & 16.9 & 25.3 & 18.7 \\
\hline 607 & $9-1$ & 16.0 & 72.85 & 1.6338 & 25.2 & 8.3 & 1.1 & 16.5 & 25.6 & 19.4 \\
\hline 607 & $9-1$ & 31.0 & 73.00 & 1.6375 & 24.1 & 13.3 & 1.8 & 20.8 & 26.6 & 19.7 \\
\hline 607 & $9-1$ & 53.0 & 73.22 & 1.6426 & 23.4 & 6.1 & 2.4 & 14.9 & 24.8 & 18.7 \\
\hline
\end{tabular}

Column identifications for species percentages are as follows: species 1, Globigerinoides ruber (white); species 2, Globigerina bulloides, species 3, Neogloboquadrina pachyderma (sinistral); and species 4, Globorotalia inflata.

* Ages based on TP607 time scale.

TABLE A3. Percent $\mathrm{CaCO}_{3}$ Data from Site 609

\begin{tabular}{rrrrrr}
\hline \multicolumn{3}{c}{$\begin{array}{c}\text { DSDP Sample } \\
\text { Identification }\end{array}$} & & & \\
\cline { 1 - 2 } Hole & $\begin{array}{c}\text { Core- } \\
\text { section }\end{array}$ & $\begin{array}{r}\text { Depth, } \\
\mathrm{cm}\end{array}$ & $\begin{array}{r}\text { Composite } \\
\text { Depth, } \mathrm{m}\end{array}$ & $\begin{array}{c}\mathrm{Age}^{*} \\
\mathrm{Ma}^{*}\end{array}$ & $\begin{array}{c}\mathrm{CaCO}_{3}, \\
\%\end{array}$ \\
\hline 609 & $1-1$ & 6.0 & 0.06 & 0.0000 & 79.1 \\
609 & $1-1$ & 31.0 & 0.31 & 0.0040 & 71.4 \\
609 & $1-1$ & 61.0 & 0.61 & 0.0087 & 40.6 \\
609 & $1-1$ & 91.0 & 0.91 & 0.0134 & 32.7 \\
609 & $1-1$ & 121.0 & 1.21 & 0.0178 & 22.7 \\
609 & $1-2$ & 1.0 & 1.51 & 0.0219 & 10.5 \\
609 & $1-2$ & 31.0 & 1.81 & 0.0261 & 16.2 \\
609 & $1-2$ & 61.0 & 2.11 & 0.0307 & 29.0 \\
609 & $1-2$ & 91.0 & 2.41 & 0.0351 & 23.2 \\
609 & $1-2$ & 121.0 & 2.71 & 0.0395 & 35.5
\end{tabular}

TABLE A3. (continued)

\begin{tabular}{lrrrrr}
\hline \multicolumn{7}{c}{$\begin{array}{c}\text { DSDP Sample } \\
\text { Identification }\end{array}$} & & & \\
\cline { 1 - 4 } Hole & $\begin{array}{c}\text { Core- } \\
\text { section }\end{array}$ & $\begin{array}{r}\text { Depth, } \\
\mathrm{cm}\end{array}$ & $\begin{array}{r}\text { Composite } \\
\text { Depth, } \mathrm{m}\end{array}$ & $\begin{array}{c}\text { Age, } \\
\mathrm{Ma}^{*}\end{array}$ & $\begin{array}{c}\mathrm{CaCO}_{3}, \\
\%\end{array}$ \\
\hline 609 & $1-3$ & 1.0 & 3.01 & 0.0438 & 31.4 \\
609 & $1-3$ & 31.0 & 3.31 & 0.0485 & 56.1 \\
609 & $1-3$ & 61.0 & 3.61 & 0.0539 & 43.1 \\
609 & $1-3$ & 91.0 & 3.91 & 0.0595 & 19.8 \\
609 & $1-3$ & 121.0 & 4.21 & 0.0660 & 37.1 \\
609 & $1-4$ & 1.0 & 4.51 & 0.0724 & 64.2 \\
609 & $1-4$ & 31.0 & 4.81 & 0.0786 & 78.8 \\
609 & $1-4$ & 61.0 & 5.11 & 0.0845 & 54.8 \\
609 & $1-4$ & 91.0 & 5.41 & 0.0889 & 76.1 \\
609 & $1-4$ & 121.0 & 5.71 & 0.0932. & 79.3
\end{tabular}


TABLE A3. (continued)

\begin{tabular}{|c|c|c|c|c|c|}
\hline \multicolumn{3}{|c|}{$\begin{array}{l}\text { DSDP Sample } \\
\text { Identification } \\
\end{array}$} & \multirow[b]{2}{*}{$\begin{array}{r}\text { Composite } \\
\text { Depth, m }\end{array}$} & \multirow[b]{2}{*}{$\begin{array}{l}\text { Age, } \\
\mathrm{Ma}^{*}\end{array}$} & \multirow[b]{2}{*}{$\begin{array}{c}\mathrm{CaCO}_{3}, \\
\%\end{array}$} \\
\hline Hole & $\begin{array}{l}\text { Core- } \\
\text { section }\end{array}$ & $\begin{array}{c}\text { Depth, } \\
\mathrm{cm}\end{array}$ & & & \\
\hline 609 & $1-5$ & 1.0 & 6.01 & 0.0974 & 66.2 \\
\hline 609 & $1-5$ & 31.0 & 6.31 & 0.1017 & 61.2 \\
\hline 609 & $1-5$ & 61.0 & 6.61 & 0.1056 & 66.8 \\
\hline 609 & $1-5$ & 79.0 & 6.79 & 0.1081 & 78.6 \\
\hline $609 B$ & $2-3$ & 60.5 & 7.09 & 0.1125 & 78.3 \\
\hline $609 B$ & $2-3$ & 90.5 & 7.39 & 0.1173 & 68.8 \\
\hline $609 B$ & $2-3$ & 120.5 & 7.69 & 0.1228 & 70.1 \\
\hline $609 B$ & $2-4$ & 1.0 & 7.99 & 0.1291 & 38.4 \\
\hline $609 B$ & $2-4$ & 31.0 & 8.30 & 0.1360 & 31.8 \\
\hline $609 \mathrm{~B}$ & $2-4$ & 61.0 & 8.60 & 0.1430 & 13.9 \\
\hline 609 & $2-1$ & 31.0 & 8.89 & 0.1537 & 15.8 \\
\hline 609 & $2-1$ & 61.0 & 9.19 & 0.1649 & 36.5 \\
\hline 609 & $2-1$ & 91.0 & 9.49 & 0.1729 & 58.0 \\
\hline 609 & $2-1$ & 121.0 & 9.80 & 0.1795 & 28.4 \\
\hline 609 & $2-2$ & 1.0 & 10.09 & 0.1842 & 34.7 \\
\hline 609 & $2-2$ & 31.0 & 10.39 & 0.1877 & 47.8 \\
\hline 609 & $2-2$ & 61.0 & 10.69 & 0.1914 & 64.6 \\
\hline 609 & $2-2$ & 91.0 & 10.99 & 0.1956 & 72.1 \\
\hline 609 & $2-2$ & 121.0 & 11.30 & 0.2006 & 66.6 \\
\hline 609 & $2-3$ & 1.0 & 11.59 & 0.2064 & 75.1 \\
\hline 609 & $2-3$ & 31.0 & 11.89 & 0.2133 & 61.0 \\
\hline 609 & $2-3$ & 61.0 & 12.19 & 0.2209 & 12.9 \\
\hline 609 & $2-3$ & 91.0 & 12.49 & 0.2262 & 35.5 \\
\hline 609 & $2-3$ & 121.0 & 12.80 & 0.2314 & 68.8 \\
\hline 609 & $2-4$ & 1.0 & 13.09 & 0.2362 & 80.1 \\
\hline 609 & $2-4$ & 31.0 & 13.39 & 0.2405 & 43.2 \\
\hline 609 & $2-4$ & 61.0 & 13.69 & 0.2444 & 23.6 \\
\hline 609 & $2-4$ & 91.0 & 13.99 & 0.2479 & 39.4 \\
\hline 609 & $2-4$ & 121.0 & 14.30 & 0.2507 & 23.6 \\
\hline 609 & $2-5$ & 1.0 & 14.59 & 0.2533 & 52.0 \\
\hline 609 & $2-5$ & 31.0 & 14.89 & 0.2558 & 38.7 \\
\hline 609 & $2-5$ & 61.0 & 15.19 & 0.2582 & 43.0 \\
\hline 609 & $2-5$ & 91.0 & 15.49 & 0.2605 & 17.1 \\
\hline 609 & $2-5$ & 121.0 & 15.80 & 0.2649 & 13.1 \\
\hline 609 & $2-6$ & 1.0 & 16.09 & 0.2716 & 67.7 \\
\hline 609 & $2-6$ & 31.0 & 16.40 & 0.2794 & 77.4 \\
\hline 609 & $2-6$ & 61.0 & 16.69 & 0.2889 & 58.9 \\
\hline 609 & $2-6$ & 91.0 & 16.99 & 0.3003 & 53.8 \\
\hline 609 & $2-6$ & 121.0 & 17.30 & 0.3039 & 78.5 \\
\hline 609 & $2-7$ & 1.0 & 17.59 & 0.3076 & 54.3 \\
\hline $609 B$ & $3-3$ & 31.0 & 17.90 & 0.3111 & 75.3 \\
\hline $609 B$ & $3-3$ & 61.0 & 18.19 & 0.3146 & 66.2 \\
\hline $609 B$ & $3-3$ & 91.0 & 18.49 & 0.3208 & 83.3 \\
\hline $609 B$ & $3-3$ & 121.0 & 18.80 & 0.3262 & 69.6 \\
\hline $609 B$ & $3-3$ & 135.5 & 18.94 & 0.3287 & 68.1 \\
\hline $609 B$ & $3-4$ & 0.5 & 19.09 & 0.3311 & 49.6 \\
\hline $609 B$ & $3-4$ & 15.5 & 19.24 & 0.3334 & 41.6 \\
\hline $609 B$ & $3-4$ & 31.0 & 19.40 & 0.3356 & 4.6 \\
\hline $609 B$ & $3-4$ & 45.5 & 19.54 & 0.3379 & 7.0 \\
\hline $609 B$ & $3-4$ & 61.5 & 19.70 & 0.3404 & 24.1 \\
\hline $609 B$ & $3-4$ & 75.5 & 19.84 & 0.3424 & 35.9 \\
\hline $609 B$ & $3-4$ & 91.0 & 19.99 & 0.3447 & 43.2 \\
\hline $609 B$ & $3-4$ & 105.5 & 20.14 & 0.3468 & 16.4 \\
\hline $609 B$ & $3-4$ & 121.0 & 20.30 & 0.3490 & 8.9 \\
\hline $609 B$ & $3-4$ & 135.5 & 20.44 & 0.3511 & 22.6 \\
\hline & $3-5$ & 1.0 & 20.59 & 0.3533 & 38.8 \\
\hline & $3-5$ & 15.5 & 20.74 & 0.3555 & 39.9 \\
\hline $609 \mathrm{~B}$ & $3-5$ & 31.0 & 20.90 & 0.3579 & 59.0 \\
\hline
\end{tabular}

TABLE A3. (continued)

\begin{tabular}{|c|c|c|c|c|c|}
\hline \multicolumn{3}{|c|}{$\begin{array}{l}\text { DSDP Sample } \\
\text { Identification }\end{array}$} & \multirow[b]{2}{*}{$\begin{array}{r}\text { Composite } \\
\text { Depth, m }\end{array}$} & \multirow[b]{2}{*}{$\begin{array}{l}\text { Age, } \\
\mathrm{Ma}^{*}\end{array}$} & \multirow[b]{2}{*}{$\begin{array}{c}\mathrm{CaCO}_{3}, \\
\%\end{array}$} \\
\hline Hole & $\begin{array}{l}\text { Core- } \\
\text { section }\end{array}$ & $\begin{array}{c}\text { Depth, } \\
\mathrm{cm}\end{array}$ & & & \\
\hline $609 B$ & $3-5$ & 45.5 & 21.04 & 0.3603 & 68.3 \\
\hline $609 B$ & $3-5$ & 61.0 & 21.19 & 0.3629 & 50.8 \\
\hline $609 B$ & $3-5$ & 75.5 & 21.34 & 0.3655 & 80.9 \\
\hline $609 B$ & $3-5$ & 91.0 & 21.49 & 0.3685 & 83.9 \\
\hline $609 B$ & $3-5$ & 105.5 & 21.64 & 0.3716 & 65.7 \\
\hline $609 B$ & $3-5$ & 135.5 & 21.94 & 0.3785 & 57.4 \\
\hline 609 & $3-3$ & 91.0 & 22.24 & 0.3867 & 81.0 \\
\hline 609 & $3-3$ & 121.0 & 22.55 & 0.3952 & 85.5 \\
\hline 609 & $3-4$ & 1. 0 & 22.84 & 0.4034 & 85.8 \\
\hline 609 & $3-4$ & 31.0 & 23.14 & 0.4106 & 84.3 \\
\hline 609 & $3-4$ & 61.0 & 23.44 & 0.4165 & 81.8 \\
\hline 609 & $3-4$ & 91.0 & 23.74 & 0.4215 & 80.2 \\
\hline 609 & $3-4$ & 121.0 & 24.05 & 0.4257 & 15.4 \\
\hline 609 & $3-5$ & 1.0 & 24.34 & 0.4295 & 31.6 \\
\hline 609 & $3-5$ & 31.0 & 24.64 & 0.4333 & 33.4 \\
\hline 609 & $3-5$ & 45.5 & 24.79 & 0.4350 & 14.0 \\
\hline 609 & $3-5$ & 61.0 & 24.94 & 0.4369 & 12.6 \\
\hline 609 & $3-5$ & 75.5 & 25.09 & 0.4390 & 17.7 \\
\hline 609 & $3-5$ & 91.0 & 25.24 & 0.4413 & 37.5 \\
\hline 609 & $3-5$ & 105.5 & 25.39 & 0.4434 & 28.0 \\
\hline 609 & $3-5$ & 121.0 & 25.55 & 0.4459 & 46.4 \\
\hline 609 & $3-5$ & 135.5 & 25.69 & 0.4483 & 11.9 \\
\hline 609 & $3-6$ & 1. 0 & 25.84 & 0.4505 & 16.6 \\
\hline 609 & $3-6$ & 15.5 & 25.99 & 0.4520 & 45.9 \\
\hline 609 & $3-6$ & 31.0 & 26.14 & 0.4539 & 46.6 \\
\hline 609 & $3-6$ & 45.5 & 26.29 & 0.4556 & 31.5 \\
\hline 609 & $3-6$ & 61.0 & 26.44 & 0.4577 & 17.8 \\
\hline 609 & $3-6$ & 75.5 & 26.59 & 0.4597 & 24.3 \\
\hline $609 B$ & $4-2$ & 15.5 & 26.73 & 0.4620 & 65.1 \\
\hline $609 \mathrm{~B}$ & $4-2$ & 31.0 & 26.89 & 0.4646 & 83.5 \\
\hline $609 B$ & $4-2$ & 45.5 & 27.03 & 0.4673 & 46.6 \\
\hline $609 B$ & $4-2$ & 61.0 & 27.19 & 0.4703 & 37.7 \\
\hline $609 B$ & $4-2$ & 75.5 & 27.33 & 0.4769 & 91.3 \\
\hline $609 B$ & $4-2$ & 91.0 & 27.49 & 0.4858 & 79.2 \\
\hline $609 B$ & $4-2$ & 121.0 & 27.79 & 0.5091 & 71.5 \\
\hline $609 B$ & $4-3$ & 1.0 & 28.09 & 0.5162 & 71.7 \\
\hline $609 B$ & $4-3$ & 31.0 & 28.39 & 0.5195 & 79.4 \\
\hline $609 B$ & $4-3$ & 61.0 & 28.69 & 0.5222 & 84.8 \\
\hline $609 B$ & $4-3$ & 91.0 & 28.99 & 0.5247 & 76.4 \\
\hline $609 B$ & $4-3$ & 121.0 & 29.29 & 0.5269 & 83.3 \\
\hline $609 B$ & $4-4$ & 1.0 & 29.59 & 0.5291 & 73.7 \\
\hline $609 B$ & $4-4$ & 31.0 & 29.89 & 0.5305 & 85.1 \\
\hline $609 B$ & $4-4$ & 61.0 & 30.19 & 0.5320 & 83.1 \\
\hline $609 B$ & $4-4$ & 91.0 & 30.49 & 0.5336 & 82.3 \\
\hline $609 B$ & $4-4$ & 121.0 & 30.79 & 0.5354 & 87.3 \\
\hline $609 B$ & $4-5$ & 1.0 & 31.09 & 0.5374 & 75.4 \\
\hline $609 B$ & $4-5$ & 31.0 & 31.39 & 0.5398 & 78.5 \\
\hline 609 & $4-3$ & 1.0 & 31.69 & 0.5427 & 34.4 \\
\hline 609 & $4-3$ & 15.5 & 31.83 & 0.5439 & 74.7 \\
\hline 609 & $4-3$ & 31.0 & 31.99 & 0.5455 & 56.2 \\
\hline 609 & $4-3$ & 61.0 & 32.29 & 0.5495 & 57.5 \\
\hline 609 & $4-3$ & 91.0 & 32.59 & 0.5548 & 44.9 \\
\hline 609 & $4-3$ & 121.0 & 32.89 & 0.5604 & 70.6 \\
\hline 609 & $4-4$ & 1.0 & 33.19 & 0.5713 & 73.6 \\
\hline 609 & $4-4$ & 31.0 & 33.49 & 0.5848 & 40.5 \\
\hline 609 & $4-4$ & 61.0 & 33.79 & 0.5907 & 63.4 \\
\hline 609 & $4-4$ & 91.0 & 34.09 & 0.5954 & 56.1 \\
\hline 609 & $4-4$ & 121.0 & 34.39 & 0.5992 & 65.0 \\
\hline
\end{tabular}


TABLE A3. (continued)

\begin{tabular}{|c|c|c|c|c|c|}
\hline \multicolumn{3}{|c|}{$\begin{array}{l}\text { DSDP Sample } \\
\text { Identification }\end{array}$} & \multirow[b]{2}{*}{$\begin{array}{r}\text { Composite } \\
\text { Depth, m }\end{array}$} & \multirow[b]{2}{*}{$\begin{array}{l}\text { Age, } \\
\mathrm{Ma}^{*}\end{array}$} & \multirow[b]{2}{*}{$\begin{array}{c}\mathrm{CaCO}_{3} \\
\%\end{array}$} \\
\hline Hole & $\begin{array}{l}\text { Core- } \\
\text { sectior }\end{array}$ & $\begin{array}{c}\text { Depth, } \\
\mathrm{cm}\end{array}$ & & & \\
\hline 609 & $4-5$ & 1.0 & 34.69 & 0.6042 & 65.9 \\
\hline 609 & $4-5$ & 31.0 & 34.99 & 0.6091 & 64.9 \\
\hline 609 & $4-5$ & 61.0 & 35.29 & 0.6142 & 72.7 \\
\hline 609 & $4-5$ & 91.0 & 35.59 & 0.6169 & 51.5 \\
\hline 609 & $4-5$ & 121.0 & 35.89 & 0.6199 & 39.9 \\
\hline 609 & $4-6$ & 1.0 & 36.19 & 0.6238 & 15.6 \\
\hline $609 B$ & $5-2$ & 121.0 & 36.49 & 0.6290 & 31.8 \\
\hline $609 B$ & $5-3$ & 1.0 & 36.79 & 0.6356 & 30.9 \\
\hline $609 B$ & $5-3$ & 31.0 & 37.09 & 0.6420 & 20.1 \\
\hline $609 B$ & $5-3$ & 61.0 & 37.39 & 0.6466 & 27.5 \\
\hline $609 B$ & $5-3$ & 91.0 & 37.69 & 0.6502 & 29.4 \\
\hline $609 B$ & $5-3$ & 121.0 & 37.99 & 0.6529 & 30.3 \\
\hline $609 \mathrm{~B}$ & $5-4$ & 1.0 & 38.29 & 0.6552 & 29.8 \\
\hline $609 B$ & $5-4$ & 31.0 & 38.59 & 0.6619 & 47.2 \\
\hline $609 B$ & $5-4$ & 61.5 & 38.90 & 0.6764 & 29.4 \\
\hline $609 B$ & $5-4$ & 91.0 & 39.19 & 0.6813 & 63.1 \\
\hline $609 B$ & $5-4$ & 121.0 & 39.49 & 0.6848 & 77.9 \\
\hline 609 & $5-3$ & 1. 0 & 39.79 & 0.6875 & 71.0 \\
\hline 609 & $5-3$ & 31.0 & 40.09 & 0.6892 & 59.8 \\
\hline 609 & $5-3$ & 61.0 & 40.39 & 0.6909 & 67.3 \\
\hline 609 & $5-3$ & 91.0 & 40.69 & 0.6927 & 63.9 \\
\hline 609 & $5-3$ & 121.0 & 40.99 & 0.6945 & 51.8 \\
\hline 609 & $5-4$ & 1.0 & 41.29 & 0.6961 & 3.8 \\
\hline 609 & $5-4$ & 31.0 & 41.59 & 0.6976 & 4.6 \\
\hline 609 & $5-4$ & 61.0 & 41.89 & 0.6997 & 36.5 \\
\hline 609 & $5-4$ & 91.0 & 42.19 & 0.7018 & 57.4 \\
\hline 609 & $5-4$ & 121.0 & 42.49 & 0.7040 & 42.0 \\
\hline 609 & $5-5$ & 1.0 & 42.79 & 0.7066 & 70.5 \\
\hline 609 & $5-5$ & 31.0 & 43.09 & 0.7104 & 71.5 \\
\hline 609 & $5-5$ & 61.0 & 43.39 & 0.7152 & 29.3 \\
\hline 609 & $5-5$ & 91.0 & 43.69 & 0.7186 & 15.1 \\
\hline 609 & $5-5$ & 105.5 & 43.83 & 0.7226 & 58.8 \\
\hline 609 & $5-5$ & 121.0 & 43.99 & 0.7264 & 67.4 \\
\hline 609 & $5-6$ & 1. 0 & 44.29 & 0.7328 & 77.7 \\
\hline 609 & $5-6$ & 31.0 & 44.59 & 0.7387 & 56.5 \\
\hline 609 & $5-6$ & 61.0 & 44.89 & 0.7446 & 16.9 \\
\hline 609 & $5-6$ & 91.0 & 45.19 & 0.7485 & 22.0 \\
\hline $609 B$ & $6-2$ & 61.0 & 45.49 & 0.7502 & 39.9 \\
\hline $609 B$ & $6-2$ & 91.0 & 45.79 & 0.7521 & 51.0 \\
\hline $609 B$ & $6-2$ & 121.0 & 46.09 & 0.7540 & 31.6 \\
\hline $609 B$ & $6-3$ & 1.0 & 46.39 & 0.7561 & 78.2 \\
\hline $609 B$ & $6-3$ & 31.0 & 46.69 & 0.7583 & 83.8 \\
\hline 609 & $6-1$ & 31.0 & 46.99 & 0.7607 & 76.7 \\
\hline 609 & $6-1$ & 61.0 & 47.29 & 0.7633 & 62.5 \\
\hline 609 & $6-1$ & 91.0 & 47.59 & 0.7661 & 57.7 \\
\hline 609 & $6-1$ & 121.0 & 47.89 & 0.7691 & 63.9 \\
\hline 609 & $6-2$ & 1.0 & 48.19 & 0.7723 & 65.0 \\
\hline 609 & $6-2$ & 31.0 & 48.49 & 0.7757 & 55.5 \\
\hline 609 & $6-2$ & 61.0 & 48.79 & 0.7792 & 76.4 \\
\hline 609 & $6-2$ & 91.0 & 49.09 & 0.7828 & 63.7 \\
\hline 609 & $6-2$ & 121.0 & 49.39 & 0.7863 & 39.8 \\
\hline 609 & $6-3$ & 1. 0 & 49.69 & 0.7896 & 28.9 \\
\hline 609 & $6-3$ & 31.0 & 49.99 & 0.7928 & 18.7 \\
\hline 609 & $6-3$ & 61.0 & 50.29 & 0.7959 & 11.2 \\
\hline 609 & $6-3$ & 91.0 & 50.59 & 0.7987 & 6.0 \\
\hline 609 & $6-3$ & 121.0 & 50.89 & 0.8025 & 6.2 \\
\hline 609 & $6-4$ & 1. 0 & 51.19 & 0.8069 & 10.1 \\
\hline 609 & $6-4$ & 31.0 & 51.49 & 0.8108 & 35.3 \\
\hline
\end{tabular}

TABLE A3. (continued)

\begin{tabular}{|c|c|c|c|c|c|}
\hline \multicolumn{3}{|c|}{$\begin{array}{l}\text { DSDP Sample } \\
\text { Identification } \\
\end{array}$} & \multirow[b]{2}{*}{$\begin{array}{r}\text { Composite } \\
\text { Depth, m }\end{array}$} & \multirow[b]{2}{*}{$\begin{array}{l}\text { Age, } \\
\mathrm{Ma}^{*}\end{array}$} & \multirow[b]{2}{*}{$\begin{array}{c}\mathrm{CaCO}_{3}, \\
\%\end{array}$} \\
\hline Hole & $\begin{array}{l}\text { Core- } \\
\text { section }\end{array}$ & $\begin{array}{c}\text { Depth, } \\
\mathrm{cm}\end{array}$ & & & \\
\hline 609 & $6-4$ & 61.0 & 51.79 & 0.8144 & 51.9 \\
\hline & $6-4$ & 91.0 & 52.09 & 0.8179 & \\
\hline & $6-4$ & 121.0 & 52.39 & 0.8212 & 5.5 \\
\hline & $6-5$ & 1.0 & 52.69 & 0.8245 & 0.5 \\
\hline & $6-5$ & 31.0 & 52.99 & 0.8278 & 11.4 \\
\hline & $6-5$ & 61.0 & 53.29 & 0.8313 & 33.8 \\
\hline & $6-5$ & 91.0 & 53.59 & 0.8354 & 24.2 \\
\hline & $6-5$ & 121.0 & 53.89 & 0.8402 & 8.1 \\
\hline & $6-6$ & 1.0 & 54.19 & 0.8440 & 48.4 \\
\hline & $6-6$ & 31.0 & 54.49 & 0.8479 & 5.8 \\
\hline & $6-6$ & 61.0 & & 0.8520 & 4.5 \\
\hline & $6-6$ & 91.0 & .09 & 0.85 & 3.5 \\
\hline & $6-6$ & 121.0 & .39 & 8 & 5.5 \\
\hline & $6-7$ & 1.0 & .69 & 2 & 1.5 \\
\hline & $6-7$ & 31.0 & & 5 & 5.0 \\
\hline & $6-7$ & 51.0 & & 0 . & 4.0 \\
\hline & $7-3$ & 1.0 & & & 5.4 \\
\hline & $7-1$ & 31.0 & & & 54.3 \\
\hline & $7-1$ & 61.0 & 57.09 & 0.87 & 60.0 \\
\hline & $7-1$ & 91.0 & 57.39 & 0.878 & 62.0 \\
\hline & $7-1$ & 121.0 & 57.69 & 0.8801 & 56.0 \\
\hline & $7-2$ & 1.0 & .99 & 0.8820 & 59.1 \\
\hline & & 310 & & & \\
\hline & $7-2$ & 61.0 & 58.59 & 0.8 & 41.9 \\
\hline & $7-2$ & 91.0 & 58.89 & 0.88 & 5.4 \\
\hline & $7-2$ & 121.0 & 9.19 & 0.8 & 0.5 \\
\hline & & 1.0 & .49 & 0.9 & 1.5 \\
\hline & -3 & 31.0 & .79 & 0.9 & 3.7 \\
\hline & & 61.0 & & 0.92 & 3.1 \\
\hline & 3 & 91.0 & .39 & 0.92 & 9.2 \\
\hline & -3 & 121.0 & .69 & 0.9 & 5.6 \\
\hline 60 & $7-4$ & 1.0 & 9 & 1 & 8.7 \\
\hline 60 & $7-4$ & 31.0 & 9 & 5 & 8.3 \\
\hline 60 & $7-4$ & 58.5 & 6 & ; & 1.0 \\
\hline 60 & $7-4$ & 61.0 & 9 & 0.9 & 6.0 \\
\hline 60 & $7-4$ & 91.0 & 9 & 0.9 & 8.1 \\
\hline 60 & $7-4$ & 121.0 & & 0.9 & 2.9 \\
\hline 60 & $7-5$ & 1.0 & & 0.9 & 5.2 \\
\hline 60 & $7-5$ & 31.0 & & 0.9 & 1.4 \\
\hline & $7-5$ & 61.0 & & 0.9 & .8 \\
\hline & $7-5$ & 91.0 & & 0.9 & . \\
\hline & $7-5$ & 121.0 & .69 & 0.9 & 1. \\
\hline & $7-6$ & 1.0 & 9 & & 2 \\
\hline & & 15.5 & 6 & &. \\
\hline & & 31.0 & 9 & & 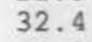 \\
\hline & $7-6$ & 61.0 & 4.59 & & 1 \\
\hline & & 91.0 & 64.89 & & 8 \\
\hline & $7-6$ & 121.0 & 65.19 & & \\
\hline & & 1.0 & 65.49 & & $\epsilon$ \\
\hline & $8-3$ & 1. & 65.79 & & 0. \\
\hline & $8-3$ & 31.0 & 66.09 & & 2. \\
\hline & $8-1$ & 61.0 & 66.39 & 0.9 & 9. \\
\hline & $8-1$ & 91.0 & 66.69 & & 0. \\
\hline & $8-$ & 121.0 & 66.99 & 0.9 & 2. \\
\hline & & 1.0 & 67.29 & & 2. \\
\hline & & 31.0 & 67.59 & & \\
\hline & & 61.0 & 67.89 & & . \\
\hline & $8-2$ & 91.0 & 68.19 & 1.0079 & 61. \\
\hline
\end{tabular}


TABLE A3. (continued)

\begin{tabular}{|c|c|c|c|c|c|}
\hline \multicolumn{3}{|c|}{$\begin{array}{l}\text { DSDP Sample } \\
\text { Identification } \\
\end{array}$} & \multirow[b]{2}{*}{$\begin{array}{r}\text { Composite } \\
\text { Depth, m }\end{array}$} & \multirow[b]{2}{*}{$\begin{array}{l}\text { Age, } \\
\mathrm{Ma}^{*}\end{array}$} & \multirow[b]{2}{*}{$\begin{array}{c}\mathrm{CaCO}_{3}, \\
\%\end{array}$} \\
\hline Hole & $\begin{array}{l}\text { Core- } \\
\text { sectior }\end{array}$ & $\begin{array}{c}\text { Depth, } \\
\mathrm{cm} \\
\end{array}$ & & & \\
\hline 609 & $8-2$ & 121.0 & 68.49 & 1.0102 & 50.7 \\
\hline 609 & $8-3$ & 1.0 & 68.79 & 1.0123 & 7.2 \\
\hline 609 & $8-3$ & 31.0 & 69.09 & 1.0157 & 18.0 \\
\hline 609 & $8-3$ & 61.0 & 69.39 & 1.0190 & 39.0 \\
\hline 609 & $8-3$ & 91.5 & 69.69 & 1.0223 & 63.3 \\
\hline 609 & $8-3$ & 121.0 & 69.99 & 1.0254 & 45.8 \\
\hline 609 & $8-4$ & 1.0 & 70.29 & 1.0286 & 49.2 \\
\hline 609 & $8-4$ & 31.0 & 70.59 & 1.0319 & 55.9 \\
\hline 609 & $8-4$ & 61.0 & 70.89 & 1.0352 & 49.7 \\
\hline 609 & $8-4$ & 91.0 & 71.19 & 1.0386 & 47.7 \\
\hline 609 & $8-4$ & 121.0 & 71.49 & 1.0422 & 17.8 \\
\hline 609 & $8-5$ & 1.0 & 71.79 & 1.0458 & 10.0 \\
\hline 609 & $8-5$ & 31.0 & 72.09 & 1.0478 & 35.2 \\
\hline 609 & $8-5$ & 61.0 & 72.39 & 1.0498 & 40.1 \\
\hline 609 & $8-5$ & 90.3 & 72.68 & 1.0518 & 16.1 \\
\hline 609 & $8-5$ & 121.0 & 72.99 & 1.0539 & 35.7 \\
\hline 609 & $8-6$ & 1.0 & 73.29 & 1.0560 & 42.0 \\
\hline 609 & $8-6$ & 31.0 & 73.59 & 1.0581 & 56.6 \\
\hline 609 & $8-6$ & 61.0 & 73.89 & 1.0602 & 63.4 \\
\hline 609 & $8-6$ & 91.0 & 74.19 & 1.0624 & 72.2 \\
\hline $609 B$ & $9-2$ & 0.5 & 74.49 & 1.0645 & 62.7 \\
\hline $609 B$ & $9-2$ & 30.5 & 74.79 & 1.0667 & 57.0 \\
\hline $609 B$ & $9-2$ & 60.5 & 75.09 & 1.0688 & 65.2 \\
\hline $609 B$ & $9-2$ & 91.0 & 75.39 & 1.0710 & 50.4 \\
\hline $609 B$ & $9-2$ & 121.0 & 75.69 & 1.0731 & 59.7 \\
\hline $609 B$ & $9-3$ & 1.0 & 75.99 & 1.0752 & 65.2 \\
\hline $609 B$ & $9-3$ & 31.0 & 76.29 & 1.0779 & 72.4 \\
\hline 609 & $9-1$ & 31.0 & 76.43 & 1.0782 & 71.8 \\
\hline 609 & $9-1$ & 61.0 & 76.74 & 1.0802 & 56.9 \\
\hline 609 & $9-1$ & 91.0 & 77.03 & 1.0822 & 39.8 \\
\hline 609 & $9-1$ & 121.0 & 77.33 & 1.0842 & 24.3 \\
\hline 609 & $9-2$ & 0.8 & 77.63 & 1.0861 & 55.5 \\
\hline 609 & $9-2$ & 31.0 & 77.93 & 1.0880 & 28.0 \\
\hline 609 & $9-2$ & 61.0 & 78.24 & 1.0922 & 42.5 \\
\hline 609 & $9-2$ & 91.0 & 78.53 & 1.0963 & 27.5 \\
\hline 609 & $9-2$ & 121.0 & 78.83 & 1.1004 & 48.3 \\
\hline 609 & $9-3$ & 1.0 & 79.13 & 1.1045 & 77.0 \\
\hline 609 & $9-3$ & 31.0 & 79.43 & 1.1087 & 74.8 \\
\hline 609 & $9-3$ & 61.0 & 79.74 & 1.1129 & 69.0 \\
\hline 609 & $9-3$ & 91.0 & 80.03 & 1.1173 & 45.3 \\
\hline 609 & $9-3$ & 121.0 & 80.33 & 1.1218 & 22.9 \\
\hline 609 & $9-4$ & 1.0 & 80.63 & 1.1265 & $28: 9$ \\
\hline 609 & $9-4$ & 31.0 & 80.93 & 1.1317 & 31.6 \\
\hline 609 & $9-4$ & 61.0 & 81.24 & 1.1369 & 18.7 \\
\hline 609 & $9-4$ & 91.0 & 81.53 & 1.1423 & 45.3 \\
\hline 609 & $9-4$ & 121.0 & 81.83 & 1.1477 & 82.6 \\
\hline 609 & $9-5$ & 1.0 & 82.13 & 1.1532 & 70.5 \\
\hline 609 & $9-5$ & 32.0 & 82.44 & 1.1587 & 73.4 \\
\hline 609 & $9-5$ & 61.0 & 82.74 & 1.1639 & 23.1 \\
\hline 609 & $9-5$ & 91.0 & 83.03 & 1.1691 & 34.2 \\
\hline 609 & $9-5$ & 121.0 & 83.33 & 1.1737 & 19.5 \\
\hline 609 & $9-6$ & 1.0 & 83.63 & 1.1762 & 22.7 \\
\hline 609 & $9-6$ & 31.0 & 83.93 & 1.1786 & 63.0 \\
\hline 609 & $9-6$ & 61.0 & 84.24 & 1.1810 & 46.0 \\
\hline & 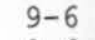 & 91.0 & 84.53 & 1.1834 & 72.8 \\
\hline 609 & $9-6$ & 121.0 & 84.83 & 1.1857 & 67.4 \\
\hline $609 B$ & $10-2$ & 91.0 & 85.13 & 1.1880 & 68.2 \\
\hline $609 B$ & $10-2$ & 121.0 & 85.43 & 1.1903 & 66.4 \\
\hline
\end{tabular}

TABLE A3. (continued)

\begin{tabular}{|c|c|c|c|c|c|}
\hline \multicolumn{3}{|c|}{$\begin{array}{l}\text { DSDP Sample } \\
\text { Identification } \\
\end{array}$} & \multirow[b]{2}{*}{$\begin{array}{r}\text { Composite } \\
\text { Depth, m }\end{array}$} & \multirow[b]{2}{*}{$\begin{array}{l}\text { Age, } \\
\mathrm{Ma}^{*}\end{array}$} & \multirow[b]{2}{*}{$\begin{array}{c}\mathrm{CaCO}_{3} \\
\%\end{array}$} \\
\hline Hole & $\begin{array}{l}\text { Core- } \\
\text { section }\end{array}$ & $\begin{array}{c}\text { Depth, } \\
\mathrm{cm}\end{array}$ & & & \\
\hline 609 & $10-1$ & 61.0 & 85.74 & 1.1926 & 58.1 \\
\hline 609 & $10-1$ & 91.0 & 86.03 & 1.1949 & 62.3 \\
\hline 609 & $10-1$ & 121.0 & 86.33 & 1.1972 & 62.1 \\
\hline 609 & $10-2$ & 1.0 & 86.63 & 1.2000 & 48.1 \\
\hline 609 & $10-2$ & 15.5 & 86.78 & 1.2026 & 35.2 \\
\hline 609 & $10-2$ & 31.0 & 86.93 & 1.2055 & 23.4 \\
\hline 609 & $10-2$ & 45.5 & 87.08 & 1.2099 & 19.6 \\
\hline 609 & $10-2$ & 61.0 & 87.24 & 1.2161 & 64.4 \\
\hline 609 & $10-2$ & 91.3 & 87.54 & 1.2270 & 88.1 \\
\hline 609 & $10-2$ & 121.0 & 87.83 & 1. 2319 & 58.1 \\
\hline 609 & $10-3$ & 1.0 & 88.13 & 1. 2348 & 61.4 \\
\hline 609 & $10-3$ & 31.0 & 88.43 & 1.2380 & 61.1 \\
\hline 609 & $10-3$ & 61.0 & 88.74 & 1.2413 & 59.0 \\
\hline 609 & $10-3$ & 91.0 & 89.03 & 1.2447 & 55.0 \\
\hline 609 & $10-3$ & 121.0 & 89.33 & 1.2480 & 52.5 \\
\hline 609 & $10-4$ & 1.0 & 89.63 & 1.2510 & 59.5 \\
\hline 609 & $10-4$ & 31.0 & 89.93 & 1.2538 & 52.6 \\
\hline 609 & $10-4$ & 61.0 & 90.24 & 1.2574 & 40.0 \\
\hline 609 & $10-4$ & 76.5 & 90.39 & 1.2602 & 54.8 \\
\hline 609 & $10-4$ & 91.0 & 90.53 & 1.2627 & 55.4 \\
\hline 609 & $10-4$ & 121.0 & 90.83 & 1.2675 & 49.4 \\
\hline 09 & $10-5$ & 1. 0 & 91.13 & 1.2719 & 71.3 \\
\hline 09 & $10-5$ & 31.0 & 91.43 & 1.2754 & 74.1 \\
\hline 609 & $10-5$ & 61.0 & 91.74 & 1. 2782 & 79.6 \\
\hline 609 & $10-5$ & 91.0 & 92.03 & 1.2803 & 71.1 \\
\hline 609 & $10-5$ & 121.0 & 92.33 & 1.2823 & 69.3 \\
\hline 609 & $10-6$ & 1.0 & 92.63 & 1.2843 & 72.8 \\
\hline 609 & $10-6$ & 31.0 & 92.93 & 1.2862 & 67.3 \\
\hline 609 & $10-6$ & 61.0 & 93.24 & 1. 2882 & 60.8 \\
\hline $609 B$ & $11-2$ & 31.0 & 93.54 & 1.2901 & 20.3 \\
\hline $609 B$ & $11-2$ & 61.0 & 93.84 & 1.2921 & 50.0 \\
\hline $609 B$ & $11-2$ & 91.0 & 94.14 & 1. 2952 & 11.4 \\
\hline $609 B$ & $11-2$ & 121.0 & 94.44 & 1. 2987 & 50.6 \\
\hline $609 B$ & $11-3$ & 1.0 & 94.74 & 1.3025 & 84.4 \\
\hline $609 B$ & $11-3$ & 31.0 & 95.04 & 1.3071 & 82.0 \\
\hline $609 B$ & $11-3$ & 61.0 & 95.34 & 1.3126 & 76.3 \\
\hline $609 B$ & $11-3$ & 91.0 & 95.64 & 1.3192 & 79.9 \\
\hline $609 B$ & $11-3$ & 121.3 & 95.94 & 1.3267 & 62.5 \\
\hline $608 B$ & $11-4$ & 0.8 & 96.24 & 1.3344 & 12.2 \\
\hline $609 B$ & $11-4$ & 31.0 & 96.54 & 1.3426 & 50.1 \\
\hline $609 B$ & $11-4$ & 61.0 & 96.84 & 1.3495 & 79.7 \\
\hline $609 B$ & $11-4$ & 91.0 & 97.14 & 1. 3552 & 78.2 \\
\hline 609 & $11-2$ & 61.0 & 97.44 & 1.3600 & 74.1 \\
\hline 609 & $11-2$ & 91.0 & 97.74 & 1.3643 & 72.6 \\
\hline 609 & $11-2$ & 121.0 & 98.04 & 1.3683 & 42.0 \\
\hline 609 & $11-2$ & 135.5 & 98.18 & 1.3702 & 27.0 \\
\hline 609 & $11-3$ & 1.0 & 98.34 & 1.3722 & 21.7 \\
\hline 609 & $11-3$ & 15.5 & 98.49 & 1.3741 & 47.7 \\
\hline 609 & $11-3$ & 31.0 & 98.64 & 1.3754 & 50.3 \\
\hline 609 & $11-3$ & 61.0 & 98.94 & 1.3778 & 49.5 \\
\hline 609 & $11-3$ & 91.0 & 99.24 & 1.3804 & 45.9 \\
\hline 609 & $11-3$ & 121.0 & 99.54 & 1. 3832 & 69.2 \\
\hline 609 & $11-4$ & 1.0 & 99.84 & 1. 3860 & 72.6 \\
\hline 609 & $11-4$ & 31.0 & 100.14 & 1.3891 & 70.3 \\
\hline 609 & $11-4$ & 61.0 & 100.44 & 1. 3924 & 67.0 \\
\hline 609 & $11-4$ & 91.0 & 100.74 & 1.3959 & 71.8 \\
\hline 609 & $11-4$ & 121.0 & 101.04 & 1.3997 & 66.7 \\
\hline 609 & $11-5$ & 1.0 & 101.34 & 1.4037 & 74.8 \\
\hline
\end{tabular}


TABLE A3. (continued)

\begin{tabular}{|c|c|c|c|c|c|}
\hline \multicolumn{3}{|c|}{$\begin{array}{l}\text { DSDP Sample } \\
\text { Identification }\end{array}$} & \multirow[b]{2}{*}{$\begin{array}{r}\text { Composite } \\
\text { Depth, m }\end{array}$} & \multirow[b]{2}{*}{$\begin{array}{l}\text { Age, } \\
\mathrm{Ma}^{*}\end{array}$} & \multirow[b]{2}{*}{$\begin{array}{c}\mathrm{CaCO}_{3}, \\
\%\end{array}$} \\
\hline Hole & $\begin{array}{l}\text { Core- } \\
\text { section }\end{array}$ & $\begin{array}{c}\text { Depth, } \\
\mathrm{cm}\end{array}$ & & & \\
\hline 609 & $11-5$ & 31.0 & 101.64 & 1.4078 & 36.5 \\
\hline 609 & $11-5$ & 45.5 & 101.78 & 1.4099 & 41.1 \\
\hline 609 & $11-5$ & 61.0 & 101.94 & 1.4120 & 32.8 \\
\hline 609 & $11-5$ & 91.0 & 102.24 & 1.4161 & 67.8 \\
\hline 609 & $11-5$ & 121.0 & 102.54 & 1.4202 & 58.4 \\
\hline 609 & $11-6$ & 1.0 & 102.84 & 1.4242 & 80.4 \\
\hline 609 & $11-6$ & 24.0 & 103.07 & 1.4272 & 51.4 \\
\hline $609 B$ & $12-2$ & 31.0 & 103.37 & 1.4311 & 77.0 \\
\hline $609 B$ & $12-2$ & 61.0 & 103.67 & 1.4348 & 81.6 \\
\hline $609 B$ & $12-2$ & 91.0 & 103.97 & 1.4384 & 80.5 \\
\hline $609 B$ & $12-2$ & 121.0 & 104.27 & 1.4419 & 77.6 \\
\hline 609 & $12-1$ & 11.0 & 104.57 & 1.4455 & 66.2 \\
\hline 609 & $12-1$ & 31.0 & 104.77 & 1.4478 & 58.4 \\
\hline 609 & $12-1$ & 61.0 & 105.07 & 1.4512 & 59.9 \\
\hline 609 & $12-1$ & 91.0 & 105.37 & 1.4547 & 59.2 \\
\hline 609 & $12-1$ & 121.0 & 105.67 & 1.4582 & 69.0 \\
\hline 609 & $12-2$ & 1. 0 & 105.97 & 1.4627 & 68.5 \\
\hline 609 & $12-2$ & 31.3 & 106.27 & 1.4672 & 35.4 \\
\hline 609 & $12-2$ & 61.0 & 106.57 & 1.4715 & 85.6 \\
\hline 609 & $12-2$ & 91.0 & 106.87 & 1.4758 & 84.9 \\
\hline 609 & $12-2$ & 121.0 & 107.17 & 1.4800 & 71.5 \\
\hline 609 & $12-3$ & 1.0 & 107.47 & 1.4841 & 76.2 \\
\hline 609 & $12-3$ & 31.0 & 107.77 & 1.4881 & 63.2 \\
\hline 609 & $12-3$ & 61.0 & 108.07 & 1.4919 & 72.2 \\
\hline 609 & $12-3$ & 91.0 & 108.37 & 1.4958 & 65.0 \\
\hline 609 & $12-3$ & 105.5 & 108.51 & 1.4976 & 59.2 \\
\hline 609 & $12-3$ & 121.0 & 108.67 & 1.4996 & 47.3 \\
\hline 609 & $12-3$ & 135.5 & 108.81 & 1.5012 & 60.8 \\
\hline 609 & $12-4$ & 1. 0 & 108.97 & 1.5030 & 65.5 \\
\hline 609 & $12-4$ & 31.0 & 109.27 & 1.5064 & 71.6 \\
\hline 609 & $12-4$ & 61.0 & 109.57 & 1.5099 & 85.8 \\
\hline 609 & $12-4$ & 91.0 & 109.87 & 1.5134 & 69.9 \\
\hline 609 & $12-4$ & 121.0 & 110.17 & 1.5170 & 73.9 \\
\hline 609 & $12-5$ & 1.0 & 110.47 & 1.5207 & 76.7 \\
\hline 609 & $12-5$ & 31.0 & 110.77 & 1.5245 & 70.9 \\
\hline 609 & $12-5$ & 61.0 & 111.07 & 1.5284 & 73.6 \\
\hline 609 & $12-5$ & 91.0 & 111.37 & 1.5323 & 50.8 \\
\hline 609 & $12-5$ & 105.5 & 111.51 & 1.5342 & 40.0 \\
\hline 609 & $12-5$ & 121.0 & 111.67 & 1.5363 & 30.9 \\
\hline 609 & $12-5$ & 135.5 & 111.81 & 1.5376 & 49.5 \\
\hline 609 & $12-6$ & 1. 0 & 111.97 & 1.5391 & 54.8 \\
\hline 609 & $12-6$ & 31.0 & 112.27 & 1.5419 & 52.3 \\
\hline 609 & $12-6$ & 61.0 & 112.57 & 1.5445 & 52.2 \\
\hline $609 B$ & $13-2$ & 31.0 & 112.87 & 1.5471 & 53.4 \\
\hline $609 \mathrm{~B}$ & $13-2$ & 61.0 & 113.17 & 1.5496 & 57.8 \\
\hline $609 B$ & $13-2$ & 91.0 & 113.47 & 1.5521 & 54.8 \\
\hline $609 B$ & $13-2$ & 121.0 & 113.77 & 1.5544 & 49.1 \\
\hline $609 B$ & $13-3$ & 1. 0 & 114.07 & 1.5567 & 50.1 \\
\hline $609 B$ & $13-3$ & 31.0 & 114.37 & 1.5589 & 55.0 \\
\hline $609 B$ & $13-3$ & 61.0 & 114.67 & 1.5610 & 44.4 \\
\hline $609 B$ & $13-3$ & 91.0 & 114.97 & 1.5630 & 57.1 \\
\hline $609 B$ & $13-3$ & 121.0 & 115.27 & 1.5651 & 54.0 \\
\hline $609 B$ & $13-4$ & 1. 0 & 115.57 & 1.5671 & 55.9 \\
\hline $609 B$ & $13-4$ & 31.0 & 115.87 & 1.5691 & 44.4 \\
\hline & $13-4$ & 61.0 & 116.17 & 1.5711 & 54.3 \\
\hline & $13-4$ & 90.8 & 116.47 & 1.5742 & 5.7 \\
\hline $609 B$ & $13-4$ & 121.0 & 116.77 & 1.5774 & 27.4 \\
\hline
\end{tabular}

TABLE A3. (continued)

\begin{tabular}{|c|c|c|c|c|c|}
\hline \multicolumn{3}{|c|}{$\begin{array}{l}\text { DSDP Sample } \\
\text { Identification } \\
\end{array}$} & \multirow[b]{2}{*}{$\begin{array}{r}\text { Composite } \\
\text { Depth, m }\end{array}$} & \multirow[b]{2}{*}{$\begin{array}{l}\text { Age, } \\
\mathrm{Ma}^{*}\end{array}$} & \multirow[b]{2}{*}{$\begin{array}{c}\mathrm{CaCO}_{3} \\
\%\end{array}$} \\
\hline Hole & $\begin{array}{l}\text { Core- } \\
\text { sectior }\end{array}$ & $\begin{array}{cc} & \text { Depth, } \\
\mathrm{cm}\end{array}$ & & & \\
\hline 609 & $13-2$ & 61.0 & 117.07 & 1.5807 & 29.0 \\
\hline 609 & & & & 67 & \\
\hline 609 & $13-2$ & 91.0 & 117. & 42 & \\
\hline 609 & $13-2$ & 121.0 & 117.6 & & \\
\hline 609 & $13-3$ & 1.0 & 117. & 1.59 & 8.2 \\
\hline 609 & $13-3$ & 31.0 & 118.27 & 1 . & 9.0 \\
\hline 0 & $13-3$ & 45.5 & 118.42 & & .3 \\
\hline & $13-3$ & 61.0 & 118.57 & & 2 \\
\hline & $13-3$ & 91.0 & 118.87 & & 8.0 \\
\hline 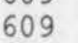 & $13-3$ & 121.0 & 119.17 & 1. & 48.8 \\
\hline 60 & $13-4$ & 1.0 & 119.47 & 1.60 & 38.2 \\
\hline 60 & $13-4$ & 15.5 & 119.61 & 1.60 & 8.7 \\
\hline 609 & $13-4$ & 31.0 & 119.77 & 1.61 & 65.4 \\
\hline 609 & $13-4$ & 61.0 & 120.07 & 1.61 & 67.4 \\
\hline 609 & $13-4$ & 91.0 & 120.37 & 1.61 & 62.9 \\
\hline 609 & $13-4$ & 121.0 & 120.67 & 1.61 & 62.9 \\
\hline 609 & $13-5$ & 1.0 & 120.97 & 1.62 & 58.5 \\
\hline 60 & $13-5$ & 31.0 & 121.27 & 1.62 & 60.6 \\
\hline 60 & $13-5$ & 61.0 & 121.57 & 1.62 & 69.7 \\
\hline & & 91.0 & 121.87 & 1.63 & 66.9 \\
\hline & $13-$ & 121.0 & 122.17 & 1.64 & 68.7 \\
\hline & $13-6$ & 1.0 & 122.47 & 1.6495 & 67.6 \\
\hline
\end{tabular}

${ }^{*}$ Ages generated by correlation to tuned site 607 record (as described in this paper).

TABLE A4. Adjusted $\delta^{18} \mathrm{O}$ and $\delta^{13} \mathrm{C}$ Values for V30-97/CHN82-24-4 Stack

\begin{tabular}{lll}
\hline $\begin{array}{l}\text { Age, } \\
\text { Ma }\end{array}$ & $\begin{array}{c}\delta^{18} \mathrm{O}, \\
\% 0\end{array}$ & $\begin{array}{c}\delta^{13} \mathrm{C}, \\
\% o\end{array}$ \\
\hline 0.0000 & 3.28 & 0.88 \\
0.0029 & 3.16 & 0.96 \\
0.0058 & 3.33 & 0.88 \\
0.0087 & 3.66 & 0.70 \\
0.0119 & 4.35 & 0.55 \\
0.0152 & 5.07 & 0.15 \\
0.0186 & 4.99 & 0.17 \\
0.0230 & 4.82 & 0.22 \\
0.0277 & 4.65 & 0.59 \\
0.0309 & 4.80 & 0.76 \\
0.0338 & 4.67 & 0.76 \\
0.0369 & 4.59 & 0.72 \\
0.0411 & 4.53 & 0.84 \\
0.0454 & 4.45 & 0.74 \\
0.0492 & 4.58 & 0.97 \\
0.0521 & 4.45 & 0.85 \\
0.0551 & 4.19 & 0.77 \\
0.0581 & 4.23 & 0.32 \\
0.0609 & 4.55 & 0.03 \\
0.0637 & 4.66 & -0.01 \\
0.0665 & 4.37 & 0.40 \\
0.0713 & 3.96 & 1.09
\end{tabular}


TABLE A4. (continued)

\begin{tabular}{|c|c|c|}
\hline $\begin{array}{c}\text { Age, } \\
\mathrm{Ma}\end{array}$ & $\begin{array}{c}\delta^{18} \mathrm{O} \\
\%\end{array}$ & $\begin{array}{c}\delta^{13} \mathrm{C}, \\
\%\end{array}$ \\
\hline $\begin{array}{l}0.0742 \\
0.0766 \\
0.0791 \\
0.0816 \\
0.0844 \\
0.0874 \\
0.0905 \\
0.0936 \\
0.0976 \\
0.1041 \\
0.1104 \\
0.1143 \\
0.1179 \\
0.1209 \\
0.1239 \\
0.1265 \\
0.1315 \\
0.1409 \\
0.1465 \\
0.1488 \\
0.1507 \\
0.1525 \\
0.1551 \\
0.1582 \\
0.1612 \\
0.1643 \\
0.1670\end{array}$ & $\begin{array}{l}3.99 \\
3.89 \\
3.77 \\
4.04 \\
4.29 \\
4.07 \\
4.02 \\
3.81 \\
3.62 \\
3.97 \\
4.00 \\
3.69 \\
3.62 \\
3.19 \\
3.05 \\
3.84 \\
4.64 \\
4.89 \\
4.93 \\
4.97 \\
4.83 \\
4.74 \\
4.58 \\
4.59 \\
4.60 \\
4.38 \\
4.35\end{array}$ & $\begin{array}{r}1.19 \\
1.07 \\
0.91 \\
0.67 \\
0.93 \\
1.01 \\
0.98 \\
1.01 \\
0.83 \\
0.71 \\
0.70 \\
0.91 \\
0.81 \\
0.78 \\
0.92 \\
0.29 \\
0.12 \\
-0.17 \\
-0.25 \\
-0.03 \\
-0.02 \\
0.07 \\
0.14 \\
-0.13 \\
0.09 \\
0.14 \\
0.21\end{array}$ \\
\hline
\end{tabular}

TABLE A4. (continued)

\begin{tabular}{lll}
\hline Age, & $\begin{array}{c}\delta^{18} \mathrm{O}, \\
\% a\end{array}$ & \multicolumn{1}{c}{$\boldsymbol{\delta}^{13} \mathrm{C}}$, \\
\hline 0.1695 & 4.30 & 0.28 \\
0.1713 & 4.36 & 0.38 \\
0.1738 & 4.50 & 0.17 \\
0.1766 & 4.42 & 0.08 \\
0.1793 & 4.52 & 0.04 \\
0.1812 & 4.61 & -0.18 \\
0.1839 & 4.33 & 0.02 \\
0.1880 & 4.06 & 0.61 \\
0.1933 & 3.73 & 0.86 \\
0.1965 & 3.48 & 0.85 \\
0.2012 & 3.69 & 0.84 \\
0.2045 & 3.80 & 1.09 \\
0.2071 & 3.63 & 0.92 \\
0.2095 & 3.55 & 0.97 \\
0.2119 & 3.56 & 0.86 \\
0.2151 & 3.61 & 0.80 \\
0.2196 & 3.53 & 0.38 \\
0.2224 & 3.56 & 0.26 \\
0.2250 & 4.67 & 0.44 \\
0.2277 & 4.33 & 0.53 \\
0.2304 & 3.99 & 0.62 \\
0.2332 & 4.28 & 0.83 \\
0.2360 & 3.64 & 0.79 \\
0.2387 & 3.45 & 0.70 \\
0.2399 & 3.40 & 0.72 \\
0.2412 & 3.91 & 0.56 \\
& & \\
\hline
\end{tabular}

TABLE A5. Percentages of Species Used in Transfer Function F13 5 , and Summer and Winter Temperature Estimates for Core V30-97

\begin{tabular}{|c|c|c|c|c|c|c|c|}
\hline $\begin{array}{l}\text { Depth, } \\
\mathrm{m}\end{array}$ & $\begin{array}{l}\text { Age, } \\
\text { Ma }\end{array}$ & $\begin{array}{c}\text { Species } \\
1\end{array}$ & $\begin{array}{c}\text { Species } \\
2\end{array}$ & $\begin{array}{c}\text { Species } \\
3\end{array}$ & $\begin{array}{c}\text { Species } \\
4\end{array}$ & $\begin{array}{l}\text { SSTs, } \\
{ }^{\circ} \mathrm{C}\end{array}$ & $\begin{array}{l}\text { SSTw, } \\
{ }^{\circ} \mathrm{C}\end{array}$ \\
\hline 0.02 & 0.0003 & 9.9 & 15.9 & 1.1 & 11.9 & 21.7 & 15.1 \\
\hline 0.05 & 0.0008 & 12.8 & 12.5 & 2.6 & 10.6 & 22.8 & 16.0 \\
\hline 0.10 & 0.0015 & 12.2 & 13.1 & 2.6 & 11.0 & 22.6 & 15.8 \\
\hline 0.12 & 0.0018 & 11.5 & 18.5 & 1.2 & 11.8 & 22.1 & 15.3 \\
\hline 0.15 & 0.0023 & 11.6 & 10.7 & 1.4 & 13.3 & 23.1 & 16.2 \\
\hline 0.20 & 0.0031 & 12.2 & 13.2 & 2.6 & 12.9 & 22.7 & 15.8 \\
\hline 0.25 & 0.0038 & 10.4 & 23.8 & 2.6 & 10.1 & 20.8 & 13.9 \\
\hline 0.30 & 0.0046 & 20.8 & 13.7 & 4.6 & 10.3 & 24.1 & 17.2 \\
\hline 0.35 & 0.0053 & 25.6 & 14.1 & 6.6 & 6.9 & 24.1 & 17.0 \\
\hline 0.38 & 0.0058 & 8.7 & 22.6 & 5.4 & 11.7 & 19.5 & 12.7 \\
\hline 0.40 & 0.0061 & 9.0 & 20.8 & 10.0 & 8.7 & 19.0 & 12.1 \\
\hline 0.43 & 0.0065 & 6.0 & 23.2 & 12.5 & 9.4 & 16.7 & 10.0 \\
\hline 0.45 & 0.0068 & 5.5 & 22.1 & 20.1 & 11.2 & 15.4 & 9.1 \\
\hline 0.50 & 0.0076 & 5.2 & 22.0 & 13.2 & 12.3 & 16.2 & 9.8 \\
\hline 0.55 & 0.0084 & 3.4 & 24.7 & 35.1 & 6.0 & 12.9 & 6.9 \\
\hline 0.60 & 0.0091 & 1.4 & 23.1 & 30.5 & 11.2 & 11.5 & 6.0 \\
\hline 0.62 & 0.0094 & 0.8 & 29.9 & 19.9 & 7.8 & 11.3 & 5.3 \\
\hline 0.65 & 0.0099 & 4.1 & 15.5 & 35.1 & 6.6 & 12.9 & 8.3 \\
\hline 0.70 & 0.0106 & 0.6 & 22.0 & 28.4 & 8.0 & 11.5 & 6.1 \\
\hline 0.75 & 0.0114 & 4.7 & 19.3 & 32.9 & 8.6 & 13.3 & 8.3 \\
\hline 0.76 & 0.0115 & 0.7 & 20.3 & 9.3 & 17.0 & 14.4 & 8.7 \\
\hline 0.80 & 0.0121 & 1.9 & 21.5 & 16.7 & 13.1 & 13.7 & 7.7 \\
\hline 0.85 & 0.0128 & 4.0 & 20.9 & 8.1 & 19.6 & 16.7 & 10.5 \\
\hline 0.90 & 0.0136 & 2.9 & 29.8 & 13.1 & 15.1 & 13.4 & 7.3 \\
\hline 0.95 & 0.0143 & 4.2 & 20.8 & 8.7 & 20.2 & 16.8 & 10.5 \\
\hline
\end{tabular}


TABLE A5. (continued)

\begin{tabular}{|c|c|c|c|c|c|c|c|}
\hline $\begin{array}{c}\text { Depth, } \\
\text { m }\end{array}$ & $\begin{array}{l}\text { Age, } \\
\text { Ma }\end{array}$ & $\begin{array}{c}\text { Species } \\
1 \\
\end{array}$ & $\begin{array}{c}\text { Species } \\
2\end{array}$ & $\begin{array}{c}\text { Species } \\
3\end{array}$ & $\begin{array}{c}\text { Species } \\
4\end{array}$ & $\begin{array}{l}\text { SSTs, } \\
{ }^{\circ} \mathrm{C} \\
\end{array}$ & $\begin{array}{l}\text { SSTw, } \\
{ }^{\circ} \mathrm{C}\end{array}$ \\
\hline 1.00 & 0.0151 & 3.1 & 24.6 & 8.7 & 25.7 & 15.6 & 9.9 \\
\hline 1.05 & 0.0158 & 1.9 & 42.2 & 4.1 & 15.9 & 10.9 & 7.7 \\
\hline 1.10 & 0.0166 & 4.5 & 20.4 & 8.4 & 18.2 & 17.0 & 10.7 \\
\hline 1.15 & 0.0173 & 5.2 & 17.6 & 8.3 & 20.7 & 18.3 & 11.6 \\
\hline 1.20 & 0.0180 & 7.2 & 17.1 & 4.5 & 24.3 & 20.6 & 13.9 \\
\hline 1.25 & 0.0188 & 3.2 & 21.1 & 11.4 & 18.8 & 15.6 & 9.4 \\
\hline 1.30 & 0.0195 & 2.8 & 21.7 & 7.5 & 17.1 & 15.6 & 9.8 \\
\hline 1.35 & 0.0203 & 3.4 & 25.9 & 5.9 & 21.3 & 15.4 & 10.1 \\
\hline 1.40 & 0.0210 & 5.3 & 21.6 & 7.8 & 20.6 & 17.5 & 11.2 \\
\hline 1.45 & 0.0218 & 1.7 & 25.7 & 20.1 & 5.0 & 12.8 & 6.7 \\
\hline 1.50 & 0.0226 & 2.9 & 20.8 & 15.8 & 13.7 & 14.6 & 8.5 \\
\hline 1.55 & 0.0233 & 1.4 & 19.7 & 29.9 & 15.5 & 11.8 & 6.3 \\
\hline 1.60 & 0.0241 & 1.4 & 26.9 & 26.2 & 16.1 & 11.6 & 5.5 \\
\hline 1.65 & 0.0249 & 1.1 & 18.6 & 26.0 & 19.4 & 12.5 & 6.5 \\
\hline 1.70 & 0.0256 & 2.1 & 23.0 & 25.8 & 9.3 & 12.5 & 6.8 \\
\hline 1.75 & 0.0264 & 1.0 & 21.6 & 25.4 & 19.9 & 12.0 & 6.1 \\
\hline 1.80 & 0.0272 & 1.2 & 24.3 & 18.9 & 8.4 & 12.5 & 6.7 \\
\hline 1.85 & 0.0280 & 1.9 & 29.4 & 23.9 & 7.1 & 12.2 & 5.8 \\
\hline 1.90 & 0.0288 & 0.3 & 28.1 & 30.9 & 7.7 & 10.6 & 4.8 \\
\hline 1.95 & 0.0296 & 1.7 & 38.8 & 22.7 & 5.2 & 12.2 & 4.6 \\
\hline 2.00 & 0.0304 & 0.9 & 38.8 & 15.9 & 5.8 & 10.8 & 4.5 \\
\hline 2.05 & 0.0313 & 1.2 & 33.9 & 17.0 & 11.6 & 11.1 & 5.1 \\
\hline 2.10 & 0.0321 & 1.8 & 36.7 & 14.3 & 10.7 & 11.6 & 5.5 \\
\hline 2.15 & 0.0329 & 2.7 & 27.3 & 14.5 & 5.8 & 13.7 & 7.5 \\
\hline 2.20 & 0.0338 & 1.9 & 42.4 & 15.5 & 7.0 & 11.9 & 5.0 \\
\hline 2.25 & 0.0347 & 3.0 & 23.1 & 12.7 & 8.0 & 14.8 & 8.7 \\
\hline 2.30 & 0.0355 & 0.7 & 25.3 & 16.2 & 6.1 & 12.4 & 6.7 \\
\hline 2.35 & 0.0364 & 2.1 & 26.1 & 19.5 & 5.4 & 13.0 & 6.9 \\
\hline 2.40 & 0.0373 & 2.8 & 25.7 & 9.6 & 11.1 & 14.4 & 8.6 \\
\hline 2.45 & 0.0382 & 2.1 & 23.4 & 8.6 & 10.3 & 14.6 & 8.9 \\
\hline 2.50 & 0.0392 & 3.0 & 22.7 & 10.5 & 13.0 & 15.0 & 9.1 \\
\hline 2.55 & 0.0401 & 3.0 & 15.5 & 11.6 & 10.4 & 16.7 & 10.3 \\
\hline 2.60 & 0.0410 & 3.1 & 17.1 & 12.0 & 12.6 & 16.2 & 9.9 \\
\hline 2.65 & 0.0420 & 2.4 & 15.7 & 9.8 & 8.4 & 16.7 & 10.4 \\
\hline 2.70 & 0.0429 & 4.0 & 23.6 & 6.7 & 11.1 & 16.1 & 10.2 \\
\hline 2.75 & 0.0439 & 3.6 & 21.1 & 10.8 & 6.3 & 15.9 & 9.7 \\
\hline 2.80 & 0.0449 & 2.8 & 23.3 & 10.7 & 8.8 & 14.8 & 8.9 \\
\hline 2.85 & 0.0458 & 1.9 & 34.0 & 15.7 & 5.1 & 12.3 & 5.8 \\
\hline 2.90 & 0.0468 & 4.0 & 18.4 & 4.8 & 11.5 & 17.6 & 11.6 \\
\hline 2.95 & 0.0478 & 4.1 & 14.0 & 3.2 & 13.3 & 19.1 & 12.8 \\
\hline 3.00 & 0.0489 & 4.4 & 19.6 & 3.0 & 5.1 & 17.9 & 12.1 \\
\hline 3.05 & 0.0499 & 3.4 & 18.7 & 2.9 & 4.9 & 17.6 & 11.9 \\
\hline 3.10 & 0.0509 & 4.6 & 13.7 & 2.0 & 10.0 & 19.5 & 13.3 \\
\hline 3.15 & 0.0519 & 4.8 & 11.9 & 4.5 & 7.1 & 19.6 & 13.1 \\
\hline 3.20 & 0.0530 & 2.5 & 31.3 & 17.0 & 4.6 & 13.1 & 6.4 \\
\hline 3.25 & 0.0540 & 3.4 & 26.7 & 11.9 & 5.5 & 14.6 & 8.4 \\
\hline 3.30 & 0.0551 & 3.0 & 22.5 & 16.0 & 6.5 & 14.5 & 8.4 \\
\hline 3.35 & 0.0562 & 1.5 & 33.7 & 18.3 & 3.7 & 12.0 & 5.4 \\
\hline 3.40 & 0.0572 & 0.9 & 32.0 & 21.6 & 1.5 & 11.7 & 5.2 \\
\hline 3.45 & 0.0583 & 1.4 & 32.7 & 24.6 & 7.4 & 11.6 & 5.0 \\
\hline 3.50 & 0.0594 & 1.7 & 28.0 & 18.9 & 3.1 & 12.7 & 6.5 \\
\hline 3.55 & 0.0605 & 3.1 & 30.8 & 21.7 & 6.6 & 13.4 & 6.4 \\
\hline 3.60 & 0.0616 & 1.7 & 29.7 & 11.1 & 5.2 & 12.9 & 7.2 \\
\hline 3.65 & 0.0628 & 2.1 & 22.7 & 17.9 & 11.6 & 13.4 & 7.5 \\
\hline 3.70 & 0.0639 & 1.1 & 20.9 & 7.3 & 9.5 & 14.9 & 9.4 \\
\hline 3.75 & 0.0651 & 2.6 & 10.2 & 6.3 & 18.1 & 19.3 & 12.1 \\
\hline 3.80 & 0.0662 & 3.2 & 17.7 & 5.3 & 17.0 & 17.4 & 11.3 \\
\hline 3.85 & 0.0674 & 5.4 & 27.2 & 3.5 & 20.2 & 17.1 & 11.6 \\
\hline 3.90 & 0.0686 & 4.8 & 21.0 & 5.2 & 15.0 & 17.4 & 11.4 \\
\hline 3.95 & 0.0698 & 5.0 & 31.3 & 2.1 & 13.8 & 16.0 & 10.7 \\
\hline
\end{tabular}


TABLE A5. (continued)

\begin{tabular}{|c|c|c|c|c|c|c|c|}
\hline $\begin{array}{c}\text { Depth, } \\
\text { m }\end{array}$ & $\begin{array}{l}\text { Age, } \\
\text { Ma }\end{array}$ & $\begin{array}{c}\text { Species } \\
1 \\
\end{array}$ & $\begin{array}{c}\text { Species } \\
2 \\
\end{array}$ & $\begin{array}{c}\text { Species } \\
3 \\
\end{array}$ & $\begin{array}{c}\text { Species } \\
4 \\
\end{array}$ & $\begin{array}{l}\text { SSTs, } \\
{ }^{\circ} \mathrm{C}\end{array}$ & $\begin{array}{l}\text { SSTw, } \\
{ }^{\circ} \mathrm{C}\end{array}$ \\
\hline 4.00 & 0.0710 & 5.0 & 20.8 & 5.2 & 13.6 & 17.5 & 11.5 \\
\hline 4.05 & 0.0723 & 6.0 & 30.6 & 3.0 & 15.5 & 17.0 & 11.2 \\
\hline 4.10 & 0.0735 & 2.2 & 26.2 & 6.6 & 11.4 & 14.2 & 8.9 \\
\hline 4.15 & 0.0748 & 3.4 & 27.7 & 2.3 & 14.2 & 15.2 & 10.3 \\
\hline 4.20 & 0.0760 & 2.8 & 24.3 & 2.2 & 12.5 & 15.7 & 10.7 \\
\hline 4.25 & 0.0773 & 4.5 & 29.4 & 1.4 & 11.9 & 15.9 & 10.8 \\
\hline 4.30 & 0.0786 & 4.7 & 26.8 & 3.7 & 12.6 & 16.3 & 10.7 \\
\hline 4.35 & 0.0799 & 5.2 & 29.7 & 3.4 & 9.2 & 16.3 & 10.5 \\
\hline 4.40 & 0.0812 & 3.9 & 24.4 & 7.4 & 9.8 & 15.8 & 9.8 \\
\hline 4.45 & 0.0825 & 4.8 & 33.1 & 6.1 & 7.7 & 15.4 & 9.1 \\
\hline 4.50 & 0.0838 & 3.9 & 31.7 & 7.4 & 6.5 & 14.7 & 8.6 \\
\hline 4.55 & 0.0851 & 4.6 & 21.0 & 2.3 & 15.1 & 17.7 & 12.1 \\
\hline 4.60 & 0.0864 & 5.0 & 15.0 & 2.1 & 10.3 & 19.4 & 13.2 \\
\hline 4.65 & 0.0877 & 4.9 & 9.4 & 1.6 & 13.6 & 20.9 & 14.2 \\
\hline 4.70 & 0.0890 & 5.2 & 9.8 & 1.3 & 15.5 & 21.1 & 14.4 \\
\hline 4.75 & 0.0903 & 4.0 & 12.6 & 1.2 & 15.0 & 19.8 & 13.5 \\
\hline 4.80 & 0.0916 & 8.1 & 8.7 & 1.7 & 13.9 & 22.3 & 15.3 \\
\hline 4.85 & 0.0929 & 6.5 & 11.0 & 1.6 & 14.9 & 21.3 & 14.6 \\
\hline 4.90 & 0.0943 & 5.4 & 9.5 & 0.0 & 18.9 & 21.8 & 14.9 \\
\hline 4.95 & 0.0959 & 9.1 & 8.5 & 0.0 & 19.1 & 23.4 & 16.4 \\
\hline 5.00 & 0.0976 & 6.1 & 23.9 & 3.7 & 14.4 & 17.9 & 11.9 \\
\hline 5.05 & 0.0993 & 8.9 & 25.0 & 1.7 & 14.4 & 20.0 & 13.6 \\
\hline 5.09 & 0.1007 & 5.1 & 30.4 & 2.4 & 11.0 & 16.2 & 10.6 \\
\hline 5.13 & 0.1021 & 2.8 & 27.4 & 5.2 & 10.2 & 14.6 & 9.3 \\
\hline 5.17 & 0.1035 & 3.5 & 26.5 & 6.8 & 11.5 & 15.1 & 9.4 \\
\hline 5.21 & 0.1049 & 4.5 & 21.4 & 8.6 & 9.8 & 16.6 & 10.4 \\
\hline 5.25 & 0.1062 & 5.6 & 24.4 & 4.5 & 11.5 & 17.3 & 11.3 \\
\hline 5.29 & 0.1076 & 7.3 & 21.1 & 5.4 & 12.5 & 18.8 & 12.4 \\
\hline 5.34 & 0.1093 & 2.8 & 23.8 & 7.6 & 12.8 & 15.1 & 9.4 \\
\hline 5.38 & 0.1106 & 2.3 & 18.5 & 5.7 & 15.7 & 16.5 & 10.6 \\
\hline 5.42 & 0.1120 & 5.4 & 0.0 & 1.5 & 23.6 & 24.5 & 15.9 \\
\hline 5.46 & 0.1133 & 3.6 & 18.4 & 2.7 & 25.2 & 18.5 & 12.6 \\
\hline 5.50 & 0.1147 & 4.7 & 19.3 & 5.7 & 18.3 & 17.8 & 11.6 \\
\hline 5.54 & 0.1160 & 5.6 & 15.5 & 2.0 & 28.8 & 21.2 & 14.6 \\
\hline 5.58 & 0.1173 & 9.0 & 26.0 & 1.6 & 19.0 & 20.5 & 14.0 \\
\hline 5.62 & 0.1187 & 11.5 & 20.7 & 1.3 & 22.7 & 23.1 & 16.3 \\
\hline 5.66 & 0.1200 & 9.1 & 19.7 & 4.3 & 22.2 & 21.1 & 14.3 \\
\hline 5.70 & 0.1213 & 18.8 & 19.7 & 2.2 & 5.3 & 25.0 & 16.9 \\
\hline 5.74 & 0.1227 & 14.9 & 24.2 & 3.7 & 20.9 & 25.1 & 16.8 \\
\hline 5.78 & 0.1240 & 16.4 & 20.0 & 2.7 & 19.3 & 25.0 & 17.4 \\
\hline 5.82 & 0.1253 & 9.8 & 26.4 & 6.1 & 19.6 & 20.8 & 13.4 \\
\hline 5.86 & 0.1266 & 6.3 & 32.1 & 8.0 & 17.1 & 17.1 & 10.3 \\
\hline 5.90 & 0.1279 & 5.0 & 39.6 & 11.7 & 7.5 & 15.6 & 7.6 \\
\hline 5.94 & 0.1293 & 0.0 & 55.5 & 7.9 & 3.9 & 8.5 & 5.5 \\
\hline 5.98 & 0.1306 & 1.7 & 44.7 & 17.3 & 4.3 & 12.0 & 4.7 \\
\hline 6.02 & 0.1318 & 2.5 & 44.8 & 10.5 & 9.4 & 12.1 & 6.2 \\
\hline 6.06 & 0.1330 & 2.5 & 39.3 & 5.0 & 10.0 & 12.2 & 7.4 \\
\hline 6.10 & 0.1342 & 4.0 & 21.5 & 5.2 & 16.9 & 16.8 & 11.0 \\
\hline 6.20 & 0.1373 & 1.6 & 23.6 & 1.6 & 15.5 & 15.1 & 10.4 \\
\hline 6.25 & 0.1388 & 1.4 & 21.3 & 0.6 & 25.0 & 16.3 & 11.6 \\
\hline 6.35 & 0.1419 & 5.6 & 16.2 & 6.9 & 22.6 & 19.3 & 12.5 \\
\hline 6.40 & 0.1435 & 3.4 & 31.0 & 2.9 & 13.0 & 14.5 & 9.6 \\
\hline 6.45 & 0.1452 & 4.2 & 18.6 & 2.0 & 14.7 & 18.1 & 12.4 \\
\hline 6.50 & 0.1469 & 3.1 & 22.7 & 1.0 & 20.3 & 16.7 & 11.7 \\
\hline 6.55 & 0.1485 & 6.1 & 15.7 & 4.1 & 16.3 & 19.6 & 13.1 \\
\hline 6.60 & 0.1502 & 3.3 & 24.8 & 3.6 & 11.9 & 15.7 & 10.4 \\
\hline 6.65 & 0.1518 & 2.9 & 41.1 & 3.8 & 4.1 & 12.9 & 7.8 \\
\hline 6.70 & 0.1534 & 1.4 & 33.1 & 6.3 & 4.3 & 12.5 & 7.5 \\
\hline 6.75 & 0.1551 & 1.5 & 33.5 & 9.2 & 4.8 & 12.2 & 6.8 \\
\hline 6.80 & 0.1566 & 1.8 & 35.7 & 12.4 & 4.2 & 12.1 & 6.0 \\
\hline
\end{tabular}


TABLE A5. (continued)

\begin{tabular}{|c|c|c|c|c|c|c|c|}
\hline $\begin{array}{c}\text { Depth, } \\
\text { m }\end{array}$ & $\begin{array}{l}\text { Age, } \\
\text { Ma }\end{array}$ & $\begin{array}{c}\text { Species } \\
1\end{array}$ & $\begin{array}{c}\text { Species } \\
2 \\
\end{array}$ & $\begin{array}{c}\text { Species } \\
3\end{array}$ & $\begin{array}{c}\text { Species } \\
4\end{array}$ & $\begin{array}{l}\text { SSTs, } \\
{ }^{\circ} \mathrm{C}\end{array}$ & $\begin{array}{l}\text { SSTw, } \\
{ }^{\circ} \mathrm{C}\end{array}$ \\
\hline 6.85 & 0.1582 & 2.7 & 26.3 & 15.6 & 2.5 & 14.0 & 7.8 \\
\hline 6.90 & 0.1598 & 1.4 & 26.3 & 15.7 & 3.1 & 13.1 & 7.1 \\
\hline 6.95 & 0.1614 & 1.2 & 22.1 & 15.1 & 4.6 & 13.8 & 7.9 \\
\hline 7.00 & 0.1629 & 2.9 & 23.5 & 10.4 & 5.3 & 15.1 & 9.1 \\
\hline 7.05 & 0.1645 & 3.4 & 23.1 & 7.5 & 7.1 & 15.8 & 9.9 \\
\hline 7.10 & 0.1659 & 4.0 & 31.0 & 5.5 & 5.9 & 15.0 & 9.2 \\
\hline 7.15 & 0.1673 & 6.0 & 20.4 & 4.5 & 14.1 & 18.4 & 12.2 \\
\hline 7.20 & 0.1687 & 4.8 & 19.3 & 2.8 & 13.9 & 18.2 & 12.3 \\
\hline 7.25 & 0.1700 & 3.1 & 22.0 & 2.5 & 14.9 & 16.5 & 11.2 \\
\hline 7.30 & 0.1712 & 3.5 & 19.4 & 7.8 & 11.6 & 16.6 & 10.5 \\
\hline 7.35 & 0.1728 & 1.1 & 28.9 & 8.5 & 9.3 & 12.5 & 7.4 \\
\hline 7.40 & 0.1744 & 3.0 & 20.9 & 8.6 & 10.7 & 15.8 & 9.8 \\
\hline 7.45 & 0.1762 & 1.4 & 20.0 & 15.7 & 9.4 & 14.0 & 8.0 \\
\hline 7.50 & 0.1780 & 1.3 & 21.5 & 7.7 & 11.2 & 14.7 & 9.2 \\
\hline 7.55 & 0.1796 & 1.6 & 21.6 & 12.9 & 10.9 & 14.1 & 8.2 \\
\hline 7.60 & 0.1808 & 1.0 & 15.3 & 4. 4 & 22.0 & 17.4 & 11.1 \\
\hline 7.65 & 0.1818 & 1.2 & 11.7 & 2.4 & 20.4 & 18.9 & 12.4 \\
\hline 7.70 & 0.1826 & 1.5 & 13.2 & 5.3 & 16.6 & 17.9 & 11.4 \\
\hline 7.75 & 0.1835 & 2.5 & 17.5 & 5.8 & 17.0 & 17.0 & 10.9 \\
\hline 7.80 & 0.1844 & 1.9 & 20.3 & 3.5 & 25.7 & 16.6 & 11.2 \\
\hline 7.85 & 0.1853 & 1.7 & 21.2 & 3.5 & 24.6 & 16.1 & 10.8 \\
\hline 7.90 & 0.1861 & 2.6 & 20.1 & 0.7 & 25.8 & 17.6 & 12.5 \\
\hline 7.95 & 0.1870 & 2.1 & 26.3 & 3.4 & 16.4 & 14.4 & 9.7 \\
\hline 8.00 & 0.1879 & 3.3 & 27.7 & 2.1 & 17.5 & 15.2 & 10.5 \\
\hline 8.05 & 0.1890 & 3.4 & 32.0 & 4.8 & 14.3 & 14.1 & 9.0 \\
\hline 8.10 & 0.1902 & 7.2 & 25.2 & 1.4 & 14.5 & 18.8 & 12.8 \\
\hline 8.15 & 0.1913 & 8.6 & 20.7 & 1.8 & 13.5 & 20.3 & 13.9 \\
\hline 8.20 & 0.1925 & 5.3 & 26.5 & 2.1 & 18.8 & 17.2 & 11.9 \\
\hline 8.25 & 0.1940 & 9.3 & 11.4 & 4.6 & 16.5 & 21.7 & 14.8 \\
\hline 8.30 & 0.1969 & 5.8 & 11.2 & 5.5 & 20.7 & 20.6 & 13.5 \\
\hline 8.35 & 0.2014 & 7.3 & 10.6 & 4.2 & 28.0 & 22.7 & 15.0 \\
\hline 8.40 & 0.2046 & 3.6 & 14.1 & 4.5 & 23.4 & 19.3 & 12.6 \\
\hline 8.45 & 0.2072 & 4.1 & 13.1 & 4.1 & 26.0 & 20.2 & 13.2 \\
\hline 8.50 & 0.2096 & 5.4 & 13.7 & 4.8 & 20.5 & 20.0 & 13.1 \\
\hline 8.55 & 0.2120 & 3.9 & 19.3 & 9.8 & 13.4 & 16.5 & 10.3 \\
\hline 8.60 & 0.2144 & 3.1 & 27.1 & 9.7 & 9.4 & 14.4 & 8.5 \\
\hline 8.65 & 0.2171 & 2.3 & 32.6 & 11.5 & 7.3 & 12.8 & 6.8 \\
\hline 8.70 & 0.2197 & 4.1 & 21.1 & 5.0 & 16.8 & 17.0 & 11.2 \\
\hline 8.75 & 0.2224 & 3.5 & 23.0 & 4.4 & 15.0 & 16.2 & 10.6 \\
\hline 8.80 & 0.2250 & 3.8 & 15.1 & 4.5 & 16.4 & 18.6 & 12.2 \\
\hline 8.85 & 0.2277 & 5.8 & 14.8 & 4.4 & 20.1 & 19.9 & 13.2 \\
\hline 8.90 & 0.2304 & 4.4 & 15.3 & 2.7 & 22.0 & 19.5 & 13.1 \\
\hline 8.95 & 0.2332 & 6.1 & 12.8 & 3.4 & 18.0 & 20.5 & 13.8 \\
\hline 9.00 & 0.2360 & 7.5 & 22.6 & 2.2 & 12.6 & 19.2 & 13.0 \\
\hline 9.05 & 0.2387 & 8.5 & 21.4 & 4.7 & 11.1 & 19.6 & 12.9 \\
\hline 9.10 & 0.2399 & 9.1 & 23.1 & 2.9 & 10.4 & 20.0 & 13.4 \\
\hline 9.15 & 0.2412 & 3.8 & 27.7 & 7.6 & 5.8 & 15.2 & 9.2 \\
\hline
\end{tabular}

Column identifications for species percentages are as follows: species 1, Globigerinoides ruber (white); species 2, Globigerina bulloides; species 3, Neogloboquadrina pachyderma (sinistral); and species 4, Globorotalia inflata. 
TABLE A6. Percent $\mathrm{CaCO}_{3}$ for Core V30-97

\begin{tabular}{|c|c|c|}
\hline $\begin{array}{c}\text { Depth, } \\
\mathrm{m}\end{array}$ & $\begin{array}{l}\text { Age, } \\
\mathrm{Ma}\end{array}$ & $\begin{array}{c}\mathrm{CaCO}_{3}, \\
\%\end{array}$ \\
\hline 0.00 & 0.0000 & 82.8 \\
\hline 0.02 & 0.0003 & 85.0 \\
\hline 0.04 & 0.0006 & 83.7 \\
\hline 0.06 & 0.0009 & 85.2 \\
\hline 0.08 & 0.0012 & 84.4 \\
\hline 0.10 & 0.0015 & 84.6 \\
\hline 0.12 & 0.0018 & 83.9 \\
\hline 0.14 & 0.0021 & 84.7 \\
\hline 0.16 & 0.0024 & 82.6 \\
\hline 0.18 & 0.0027 & 81.8 \\
\hline 0.20 & 0.0031 & 83.0 \\
\hline 0.22 & 0.0034 & 81.7 \\
\hline 0.24 & 0.0037 & 81.4 \\
\hline 0.26 & 0.0040 & 81.0 \\
\hline 0.28 & 0.0043 & 78.8 \\
\hline 0.30 & 0.0046 & 78.3 \\
\hline 0.32 & 0.0049 & 77.7 \\
\hline 0.34 & 0.0052 & 73.7 \\
\hline 0.36 & 0.0055 & 70.3 \\
\hline 0.38 & 0.0058 & 68.7 \\
\hline 0.40 & 0.0061 & 65.9 \\
\hline 0.42 & 0.0064 & 69.0 \\
\hline 0.44 & 0.0067 & 64.2 \\
\hline 0.46 & 0.0070 & 67.1 \\
\hline 0.48 & 0.0073 & 63.2 \\
\hline 0.50 & 0.0076 & 58.7 \\
\hline 0.52 & 0.0079 & 63.1 \\
\hline 0.54 & 0.0082 & 57.3 \\
\hline 0.56 & 0.0085 & 62.6 \\
\hline 0.59 & 0.0090 & 55.8 \\
\hline 0.62 & 0.0094 & 56.1 \\
\hline 0.64 & 0.0097 & 53.4 \\
\hline 0.66 & 0.0100 & 52.2 \\
\hline 0.68 & 0.0103 & 55.2 \\
\hline 0.70 & 0.0106 & 52.1 \\
\hline 0.72 & 0.0109 & 53.1 \\
\hline 0.74 & 0.0112 & 57.5 \\
\hline 0.76 & 0.0115 & 49.5 \\
\hline 0.78 & 0.0118 & 57.0 \\
\hline 0.80 & 0.0121 & 57.8 \\
\hline 0.82 & 0.0124 & 58.4 \\
\hline 0.84 & 0.0127 & 58.0 \\
\hline 0.86 & 0.0130 & 58.6 \\
\hline 0.88 & 0.0133 & 59.4 \\
\hline 0.96 & 0.0145 & 60.4 \\
\hline 0.98 & 0.0148 & 60.7 \\
\hline 1.00 & 0.0151 & 59.4 \\
\hline 1.02 & 0.0154 & 60.0 \\
\hline 1.04 & 0.0157 & 59.8 \\
\hline 1.06 & 0.0160 & 58.5 \\
\hline 1.08 & 0.0163 & 56.4 \\
\hline 1.10 & 0.0166 & 53.7 \\
\hline 1.12 & 0.0169 & 53.2 \\
\hline 1.14 & 0.0172 & 54.0 \\
\hline 1.16 & 0.0175 & 51.4 \\
\hline 1.18 & 0.0177 & 50.7 \\
\hline 1.20 & 0.0180 & 53.5 \\
\hline 1.22 & 0.0183 & 52.4 \\
\hline 1.24 & 0.0186 & 51.5 \\
\hline
\end{tabular}

TABLE A6. (continued)

\begin{tabular}{|c|c|c|}
\hline $\begin{array}{c}\text { Depth, } \\
\text { m }\end{array}$ & $\begin{array}{l}\text { Age, } \\
\mathrm{Ma}\end{array}$ & $\begin{array}{c}\mathrm{CaCO}_{3}, \\
\%\end{array}$ \\
\hline 1.26 & 0.0189 & 51.3 \\
\hline 1.28 & 0.0192 & 54.2 \\
\hline 1.30 & 0.0195 & 53.3 \\
\hline 1.32 & 0.0198 & 52.8 \\
\hline 1.40 & 0.0210 & 45.0 \\
\hline 1.42 & 0.0213 & 47.4 \\
\hline 1.44 & 0.0216 & 47.0 \\
\hline 1. 46 & 0.0220 & 48.4 \\
\hline 1.48 & 0.0223 & 49.1 \\
\hline 1.50 & 0.0226 & 50.5 \\
\hline 1.52 & 0.0229 & 45.9 \\
\hline 1.54 & 0.0232 & 47.7 \\
\hline 1.56 & 0.0235 & 49.4 \\
\hline 1.58 & 0.0238 & 44.1 \\
\hline 1.60 & 0.0241 & 53.0 \\
\hline 1.62 & 0.0244 & 56.0 \\
\hline 1.64 & 0.0247 & 54.9 \\
\hline 1.66 & 0.0250 & 54.5 \\
\hline 1.68 & 0.0253 & 54.9 \\
\hline 1.70 & 0.0256 & 58.7 \\
\hline 1.72 & 0.0260 & 66.5 \\
\hline 1.74 & 0.0263 & 55.3 \\
\hline 1.76 & 0.0266 & 56.3 \\
\hline 1.78 & 0.0269 & 56.3 \\
\hline 1.80 & 0.0272 & 51.7 \\
\hline 1.82 & 0.0275 & 44.9 \\
\hline 1.84 & 0.0278 & 54.3 \\
\hline 1.86 & 0.0282 & 54.1 \\
\hline 1.88 & 0.0285 & 53.0 \\
\hline 1.90 & 0.0288 & 54.4 \\
\hline 1.92 & 0.0291 & 55.5 \\
\hline 1.94 & 0.0295 & 55.3 \\
\hline 1.96 & 0.0298 & 56.9 \\
\hline 1.98 & 0.0301 & 58.6 \\
\hline 2.00 & 0.0304 & 58.9 \\
\hline 2.02 & 0.0308 & 63.0 \\
\hline 2.04 & 0.0311 & 62.1 \\
\hline 2.06 & 0.0314 & 65.2 \\
\hline 2.08 & 0.0318 & 65.3 \\
\hline 2.10 & 0.0321 & 64.1 \\
\hline 2.12 & 0.0324 & 61.0 \\
\hline 2.14 & 0.0328 & 62.6 \\
\hline 2.16 & 0.0331 & 62.2 \\
\hline 2.18 & 0.0334 & 62.1 \\
\hline 2.20 & 0.0338 & 63.0 \\
\hline 2. 22 & 0.0341 & 61.1 \\
\hline 2.24 & 0.0345 & 64.4 \\
\hline 2.26 & 0.0348 & 65.4 \\
\hline 2.28 & 0.0352 & 62.8 \\
\hline 2.30 & 0.0355 & 63.8 \\
\hline 2.32 & 0.0359 & 61.4 \\
\hline 2.34 & 0.0362 & 61.9 \\
\hline 2.36 & 0.0366 & 61.4 \\
\hline 2.38 & 0.0369 & 58.5 \\
\hline 2.40 & 0.0373 & 63.1 \\
\hline 2.42 & 0.0377 & 69.4 \\
\hline 2.44 & 0.0381 & 67.2 \\
\hline 2.46 & 0.0384 & 62.1 \\
\hline 2.48 & 0.0388 & 68.9 \\
\hline
\end{tabular}


TABLE A6. (continued)

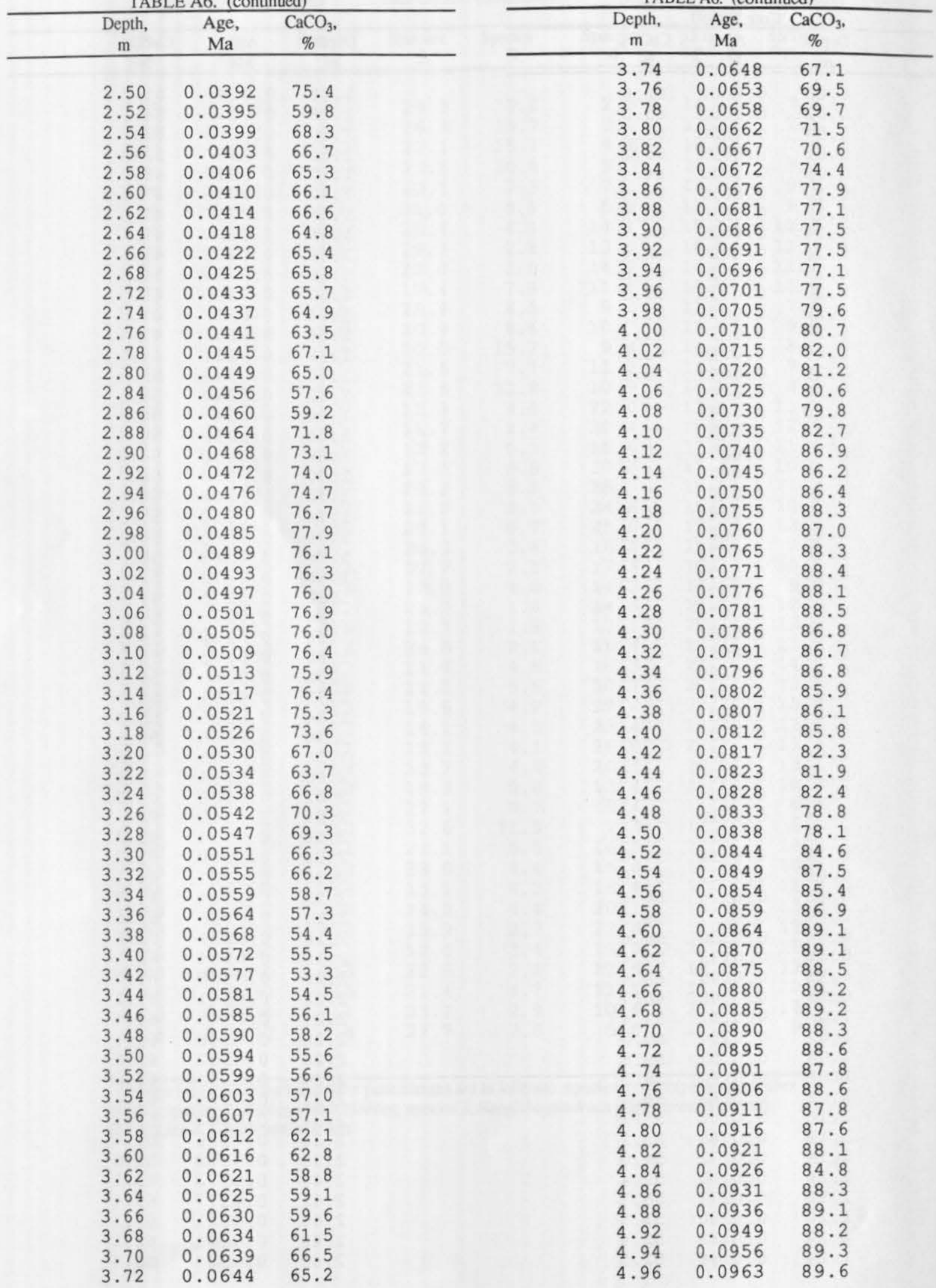


TABLE A6. (continued)

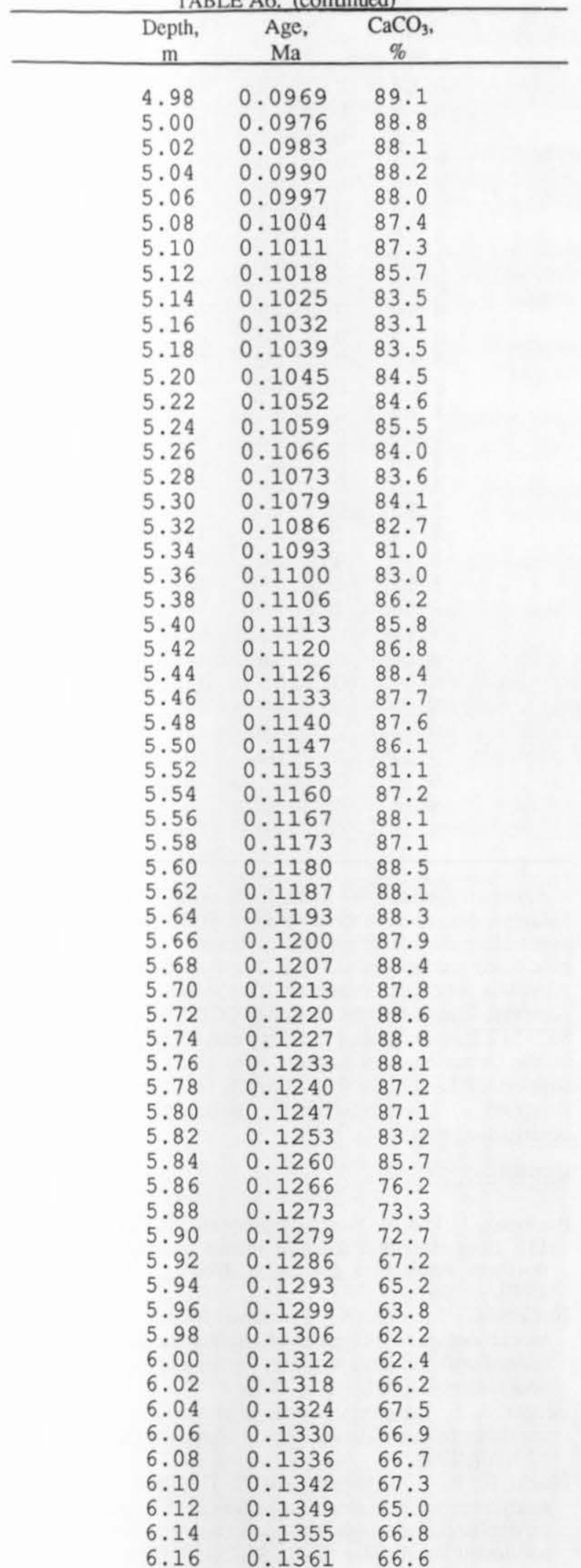

TABLE A6. (continued)

\begin{tabular}{ccc}
\hline \multicolumn{3}{c}{ TABLE A6. (continued) } \\
\hline Depth, & Age, & $\mathrm{CaCO}_{3}$, \\
$\mathrm{m}$ & $\mathrm{Ma}$ & $\%$ \\
\hline
\end{tabular}

\begin{tabular}{|c|c|c|}
\hline 6.18 & 0.1367 & 68.7 \\
\hline 6.20 & 0.1373 & 68.6 \\
\hline 6.22 & 0.1379 & 67.4 \\
\hline 6.24 & 0.1385 & 66.5 \\
\hline 6.26 & 0.1391 & 64.9 \\
\hline 6.28 & 0.1397 & 64.6 \\
\hline 6.30 & 0.1403 & 64.7 \\
\hline 6.32 & 0.1409 & 64.4 \\
\hline 6.34 & 0.1415 & 68.8 \\
\hline 6.36 & 0.1422 & 66.3 \\
\hline 6.38 & 0.1429 & 65.8 \\
\hline 6.40 & 0.1435 & 65.0 \\
\hline 6.42 & 0.1442 & 67.0 \\
\hline 6.44 & 0.1449 & 72.8 \\
\hline 6.46 & 0.1455 & 74.4 \\
\hline 6.48 & 0.1462 & 72.0 \\
\hline 6.50 & 0.1469 & 72.9 \\
\hline 6.52 & 0.1475 & 73.9 \\
\hline 6.54 & 0.1482 & 72.0 \\
\hline 6.56 & 0.1489 & 73.3 \\
\hline 6.58 & 0.1495 & 64.6 \\
\hline 6.60 & 0.1502 & 72.9 \\
\hline 6.62 & 0.1509 & 1.0 \\
\hline 6.64 & 0.1515 & 2.0 \\
\hline 6.66 & 0.1522 & 1.2 \\
\hline 6.68 & 0.1528 & 6.6 \\
\hline 6. & 0.1534 & 70.4 \\
\hline 6.72 & 0.1541 & 69.4 \\
\hline 6. & 0.1547 & \\
\hline 6. & 0.1554 & 0.1 \\
\hline 6. & 0.1560 & 2.1 \\
\hline 6.80 & 0.1566 & 3.7 \\
\hline 6.8 & 0.1573 & 8.5 \\
\hline 6.8 & 0.1579 & 8.3 \\
\hline 6.8 & 0.1586 & 9.6 \\
\hline 6.8 & 0.1592 & 62.3 \\
\hline 6.9 & 0.1598 & 8.1 \\
\hline 6.92 & 0.1604 & 9.3 \\
\hline 6.94 & 0.1611 & 0.7 \\
\hline 6.96 & 0.1617 & \\
\hline 6.98 & 0.1623 & \\
\hline 7.00 & 0.1629 & \\
\hline 7.02 & 0.1636 & 4.4 \\
\hline 7.04 & 0.1642 & 5.7 \\
\hline 7.06 & 0.1648 & 3.9 \\
\hline & 0.1653 & .0 \\
\hline & 0.1659 & 8.6 \\
\hline & 0.1665 & 1.0 \\
\hline 7.14 & 0.1671 & 9.5 \\
\hline 7. & 0.1676 & 3.7 \\
\hline & 0.1681 & \\
\hline & 0.1687 & \\
\hline & 0.1692 & \\
\hline & 0.1697 & \\
\hline & 0.1702 & \\
\hline & 0.1707 & \\
\hline & 0.1712 & \\
\hline & 0.1718 & \\
\hline & 0.1724 & \\
\hline 7.36 & 0.1731 & \\
\hline
\end{tabular}


TABLE A6. (continued)

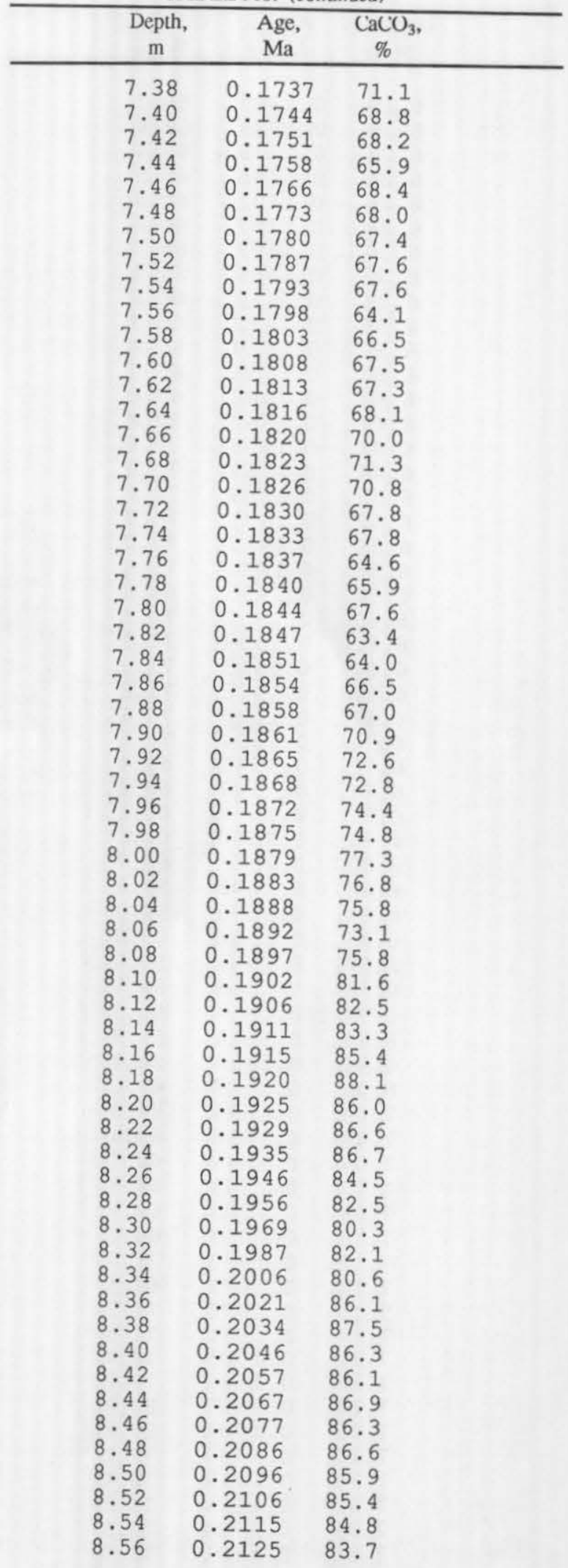

TABLE A6. (continued)

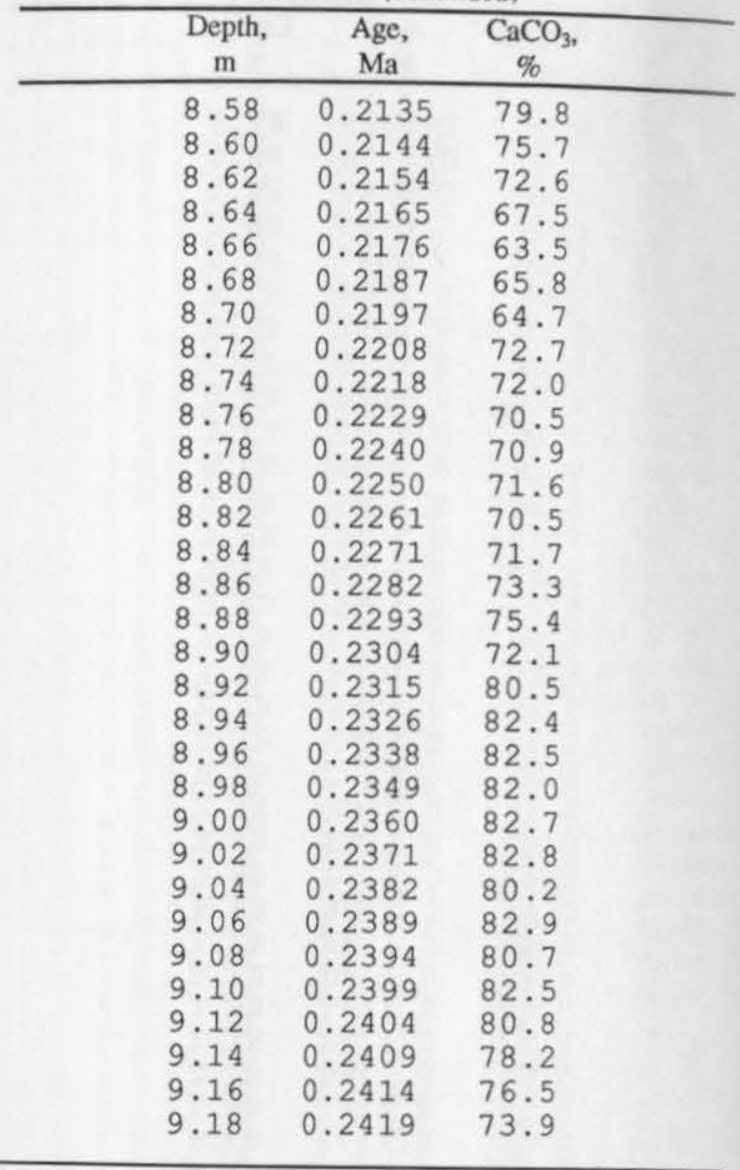

Acknowledgments. We thank J. Munkelt, C. Hardy, and K. McIntyre for efforts in the laboratory, B. Rasmussen for help assembling the manuscript, and especially A. Esmay for data processing and figure production. We thank George Kukla and Alan Mix for critical comments. This research was funded by National Science Foundation grants OCE-8219862 and OCE8521514 from the Marine Geology and Geophysics Program in the Ocean Sciences Section. We also acknowledge the support of Lamont-Doherty through the Doherty Scientist Program. Lamont-Doherty Geological Observatory contribution \# 4454.

\section{REFERENCES}

Backman, J., Pliocene biostratigraphy of DSDP sites 111 and 116 from the North Atlantic Ocean and the age of the northern hemisphere glaciation, Geology, 32, 115-137, 1979.

Backman, J., and N. J. Shackleton, Quantitative biochronology of Pliocene and Early Pleistocene - calcareous nannofossils from the Atlantic, Indian and Pacific Oceans, Mar. Micropal., 8, 141-170, 1983.

Berger, A. L., Long-term variations of caloric solar radiation resulting from the Earth's orbital elements, Quat. Res., 9. 139-167, 1978.

Black, K. P., C. S. Nelson, and C. H. Hendy, A spectral analysis procedure for dating Quaternary deep-sea cores and its application to a high-resolution Brunhes record from the southwest Pacific, Mar. Geol., 83, 21-30, 1988. 
Boyle, E. A., and L. D. Keigwin, Comparison of Atlantic and Pacific paleochemical records for the last 215,000 years: Changes in deep ocean circulation and chemical inventories, Earth Planet. Sci. Lett., 76, 135-150, 1985.

Broccoli, A. J., and S. Manabe, The influence of continental ice, atmospheric $\mathrm{CO}_{3}$ and land albedo on the climate of the last glacial maximum, Clim. Dyn., 1, 87-99, 1987.

Clement, B. M., and D. V. Kent, Geomagnetic polarity transition records from five hydraulic piston core sites in the North Atlantic, Initial Rep. Deep Sea Drill. Proj., 94, 831$852,1986$.

Clement, B. M., and D. V. Kent, Short polarity intervals within the Matuyama: Transitional field records from hydraulic piston cored sediments from the North Atlantic, Earth Planet. Sci. Lett., 81, 253-264, 1987.

Clement, B. M., and F. Robinson, The magnetostratigraphy of leg 94 sediments, Initial Rep. Deep Sea Drill. Proj., 94 , 635-650, 1986.

Hays, J. D., J. Imbrie, and N. J. Shackleton, Variations in the Earth's orbit: Pacemaker of the ice ages, Science, 194, 11211132, 1976.

Hulsemann, J., Notes: On the routine analysis of carbonates in unconsolidated sediments, J. Sediment. Petrol., 2, 622-625, 1966.

Imbrie, J., A theoretical framework for the Pleistocene ice ages, J. Geol. Soc. London, 142,417-432, 1985.

Imbrie, J., and J. Z. Imbrie, Modeling the climatic response to orbital variations, Science, 207, 943-953, 1980.

Imbrie, J., J. Hays, D. Martinson, A. McIntyre, A. Mix, J. Morley, N. Pisias, W. Prell, and N. J. Shackleton, The orbital theory of Pleistocene climate: Support from a revised chronology of the marine $\delta^{18} \mathrm{O}$ record, in Milankovitch and Climate, Part I, edited by A. Berger et al., pp. 269-305, D. Reidel, Hingham, Mass., 1984.

Keffer, T., D. G. Martinson, and B. H. Corliss, The position of the Gulf Stream during Quaternary glaciations, Science, 241, 440-442, 1988.

Kent, D. V., Post-depositional remanent magnetization in deep-sea sediment, Nature, 246, 32-34, 1973.

Kukla, G. J., Correlation between loesses and deep-sea sediments, Geol. Foeren. Stockholm Foerh., 92, 148-180, 1970.

Kukla, G. J., Loess stratigraphy in Central China and correlation with an extended oxygen isotope stage scale, Quat. Sci. Rev., 6, 191-219, 1987.

Kutzbach, J. E., Monsoon climate of the early Holocene: Climatic experiment using the Earth's orbital parameters for 9000 years ago, Science, 214, 59-61, 1981.

Kutzbach, J. E., and P. J. Guetter, The influence of changing orbital parameters and surface boundary conditions on climate simulations for the past 18,000 years, J. Atmos. Sci., 43, 1726-1759, 1984.

Maasch, K. A., Statistical detection of the mid-Pleistocene transition, Clim. Dyn., 2, 133-143, 1988.

Manabe, S., and A. J. Broccoli, The influence of continental ice sheets on the climate of an ice age, J. Geophys, Res., 90, 2167-2190, 1985

Mankinen, E. A., and G. B. Dalrymple, Revised geomagnetic polarity time scale for the interval 0-5 m.y. B.P., $J$. Geophys. Res., 84, 615-626, 1979.

Mankinen, E. A., and C. S. Grommé, Paleomagnetic data from the Coso Range, California, and current status of the Cobb Mountain normal Geomagnetic Polarity Event, Geophys. Res. Lett., 9, 1279-1282, 1982.

Mankinen, E. A., J. M. Donnelly-Nolan, C. S. Grommé, and B. C. Hearn, Jr., Paleomagnetism of the Clear Lake volcanics and new limits on the age of the Jaramillo normalpolarity event, U.S. Geol. Surv. Prof. Pap. 1141, 67-82, 1980.

Martinson, D. G., W. Menke, and P. Stoffa, An inverse approach to signal correlation, J. Geophys. Res., 87, 4807 4818, 1982.

Martinson, D. G., N. G. Pisias, J. D. Hays, J. Imbrie, T. C. Moore, and N. J. Shackleton, Age dating and the orbital theory of the ice ages: development of a high-resolution 0 to 300,000-year chronostratigraphy, Quat. Res., 27, 1-29, 1987.

Milankovitch, M., Kanon der Erdbestrahlung und seine Andwendung auf das Eiszeitenproblem, Royal Serb. Acad. Sp. Publ. 133, Belgrade, p. 1-633, 1941. English translation published in 1969 by Israel Program for Scientific Translations; available from U.S. Department of Commerce.

Mix, A. C., and R. F. Fairbanks, North Atlantic surface-ocean control of Pleistocene deep-ocean circulation, Earth Planet. Sci. Lett., 73, 231-243, 1985.

Peltier, W. R., Dynamics of the ice-age Earth, Adv. Geophys. 24, 2-146, 1982.

Pisias, N. G., and T. C. Moore, The evolution of Pleistocene climate: A time series approach, Earth Planet. Sci. Lett., $52,450-458,1981$.

Prell, W. L., Oxygen and carbon isotopic stratigraphy for the Quaternary of hole 502B: Evidence for two modes of isotopic variability, Initial Rep. Deep Sea Drill. Proj., 68, 455-464, 1982.

Raymo, M. E., W. F. Ruddiman, J. Backman, B. M. Clement, and D. G. Martinson, Late Pliocene variation in northern hemisphere ice sheets and North Atlantic Deep Water circulation, Paleoceanography, this issue.

Rossignol-Strick, M., African monsoons, an immediate climatic response to orbital insolation, Nature, 303, 46-49, 1983.

Ruddiman, W. F., Late Quatemary deposition of ice-rafted sand in the subpolar North Atlantic (lat $40^{\circ}$ to $63^{\circ} \mathrm{N}$ ), Geol. Soc. Am. Bull., 88, 1813-1827, 1977.

Ruddiman, W. F., and A. Esmay, A streamlined foraminiferal transfer function for the subpolar North Atlantic, Initial Rep. Deep Sea Drill. Proj., 94, 1045-1057, 1986.

Ruddiman, W. F., and A. McIntyre, Oceanic mechanism for amplification of the 23,000-year ice-volume cycle, Science, 212, 617-627, 1981.

Ruddiman, W. F., and A. McIntyre, Ice-age thermal response and climatic role of the surface North Atlantic Ocean, $40^{\circ}$ to $63^{\circ}$ N, Geol. Soc. Am. Bull., 95, 381-396, 1984.

Ruddiman, W. F., and M. E. Raymo, Northern hemisphere climatic regimes during the past $3 \mathrm{Ma}$ : Possible tectonic connections, Philos. Trans. R. Soc. London, Ser. B, 318, 411-430, 1988.

Ruddiman, W. F., N. J. Shackleton, and A. McIntyre, North Atlantic sea-surface temperatures for the last 1.1 million years, North Atlantic Paleoceanography, edited by C. P. Summerhayes and N. J. Shackleton, Spec. Publ. Geol. Soc., 21, 155-173, 1986a.

Ruddiman, W. F., A. McIntyre, and M. Raymo, Matuyama 41,000-year cycles: North Atlantic Ocean and northern hemisphere ice sheets, Earth Planet. Sci. Lett., 80, 117-129, 1986b.

Ruddiman, W. F., A. McIntyre, and M. Raymo, Paleoenvironmental results from North Atlantic sites 607 and 609, Initial Rep. Deep Sea Drill. Proj., 94, 855-878, $1986 \mathrm{c}$.

Ruddiman, W. F., D. Cameron, and B. M. Clement, Sediment 
disturbance and correlation of offset holes drilled with the hydraulic piston corer: Leg 94, Initial Rep. Deep Sea Drill. Proj., 94, 615-634, 1986d.

Saltzman, B., Modeling the $\delta^{18} \mathrm{O}$-derived record of Quaternary climatic change with low-order dynamical systems, in Irreversible Phenomena and Dynamical Systems Analysis in Geosciences, edited by C. Nicolis and G. Nicolis, pp. 355380, D. Reidel, Hingham, Mass., 1987.

Shackleton, N. J., and M. A. Hall, Stable isotope record of the hole 504 sediments: High resolution record of the Pleistocene, Initial Rep. Deep Sea Drill. Proj., 69, 431-441, 1983.

Shackleton, N. J., and N. D. Opdyke, Oxygen isotope and paleomagnetic stratigraphy of equatorial Pacific core V28238: Oxygen isotope temperatures and ice volume on a $10^{5}$ and $10^{6}$ year scale, Quat. Res., 3, 39-55, 1973.

Shackleton, N. J., and N. D. Opdyke, Oxygen isotope and paleomagnetic stratigraphy of Pacific core V28-239: Late Pliocene to latest Pleistocene, Investigations of Late Quaternary Paleoceanography and Paleoclimatology, edited by R. M. Cline and J. D. Hays, Mem. Geol. Soc. Am., $145,449-464,1976$.

Shackleton, N. J., J. Backman, H. Zimmerman, D. V. Kent, M. A. Hall, D. G. Roberts, D. Schnitker, J. G. Baldauf, A. Desprairics, R. Homrighausen, P. Huddleston, J. B. Keene, A. J. Kaltenback, K. A. O. Krumsiek, A. C. Morton, J. W. Murray, and J. Westberg-Smith, Oxygen isotope calibration of the onset of ice-rafting and history of glaciation in the North Atlantic region, Nature, 307, 620-623, 1984.

Start, G. G. and W. L. Prell, Evidence for two Pleistocene climatic modes: Data from DSDP site 502, in $\mathrm{New}_{\mathrm{w}}$ Perspectives in Climate Modeling, edited by A. L. Berne and C. Nicolis, pp. 3-22, Elsevier, New York, 1984.

Thierstein, H. R., K. R. Geitzenauer, B. Molfino, and N. ] Shackleton, Global synchroneity of late Quaternar? coccolith datum levels: Validation by oxygen isotopes Geology, 5, 400-404, 1977.

Williams, D. F., R. C. Thunell, E. Tappa, D. Rio, and I Raft, Chronology of the Pleistocene oxygen isotope recort: 0-1.88 m.y. B.P., Palaeogeogr. Palaeoclimatol. Palaedecol. 64, 221-240, 1988.

Zahn, R., K. Winn, and M. Sarnthein, Benthic foraminifere $\delta^{13} \mathrm{C}$ and accumulation rates of organic carbon: Uvigerin peregrina group and Cibicidoides wuellerstorfi Paleoceanography, 1, 27-42, 1986.

J. Backman, Department of Geology, University of Stockholm, Stockholm, Sweden, S-106 91.

B. M. Clement, Department of Geology, Floridt International University, Tamiami Trail, Miami, FL 33199

D. G. Martinson and W. F. Ruddiman, Lamont-Dohert Geological Observatory, Columbia University, Palisades, NY 10964.

M. E. Raymo, Department of Geology, Monash University Clayton, Victoria, 3168, Australia.

(Received October 11, 1988; revised February 23, 1989;

accepted February 24, 1989.) 